\title{
Decontamination Systems Information and Research Program
}

\author{
Quarterly Report \\ January - March 1995
}

\section{DISCLAIMER}

\begin{abstract}
This report was prepared as an account of work sponsored by an agency of the United States Government. Neither the United States Government nor any agency thereof, nor any of their employees, makes any warranty, express or implied, or assumes any legal liability or responsibility for the accuracy, completeness, or usefulness of any information, apparatus, product, or process disclosed, or represents that its use would not infringe privately owned rights. Reference herein to any specific commercial product, process, or service by trade name, trademark, manufacturer, or otherwise does not necessarily constitute or imply its endorsement, recommendation, or favoring by the United States Government or any agency thereof. The views and opinions of authors expressed herein do not necessarily state or reflect those of the United States Government or any agency thereof.
\end{abstract}

April 1995

Work Performed Under Contract No.: DE-FC21-92MC29467

For

U.S. Department of Energy

Office of Environmental Management

Office of Technology Development

Washington, DC
U.S. Department of Energy

Office of Fossil Energy

Morgantown Energy Technology Center

Morgantown, West Virginia

By

West Virginia University

National Research Center for Coal and Energy

Morgantown, West Virginia 


\section{DISCLAIMER}

This report was prepared as an account of work sponsored by an agency of the United States Government. Neither the United States Government nor any agency thereof, nor any of their employees, makes any warranty, express or implied, or assumes any legal liability or responsibility for the accuracy, completeness, or usefulness of any information, apparatus, product, or process disclosed, or represents that its use would not infringe privately owned rights. Reference herein to any specific commercial product, process, or service by trade name, trademark, manufacturer, or otherwise does not necessarily constitute or imply its endorsement, recommendation, or favoring by the United States Government or any agency thereof. The views and opinions of authors expressed herein do not necessarily state or reflect those of the United States Government or any agency thereof.

This report has been reproduced directly from the best available copy.

Available to DOE and DOE contractors from the Office of Scientific and Technical Information, 175 Oak Ridge Turnpike, Oak Ridge, TN 37831; prices available at (615) 576-8401.

Available to the public from the National Technical Information Service, U.S. Department of Commerce, 5285 Port Royal Road, Springfield, VA 22161; phone orders accepted at (703) 487-4650. 


\section{DISCLAIMER}

Portions of this document may be illegible in electronic image products. Images are produced from the best available original document. 


\title{
Decontamination Systems Information and Research Program
}

\author{
Quarterly Report \\ January - March 1995
}

Work Performed Under Contract No.: DE-FC21-92MC29467

U.S. Department of Energy

Office of Environmental Management

Office of Technology Development

1000 Independence Avenue

Washington, DC 20585
For

U.S. Department of Energy

Office of Fossil Energy

Morgantown Energy Technology Center P.O. Box 880 Morgantown, West Virginia 265070880

By

West Virginia University

National Research Center for Coal and Energy

P. O. Box 6064

Morgantown, West Virginia 26506

April 1995 


\section{EXECUTIVE SUMMARY}

The projects reported during this period are categorized into the following three areas: 1.0 Site Remediation Technologies, 2.0 Advanced Product Applications Testing, and 3.0 Information Systems, Public Policy, Community Outreach, and Economics. summaries of the significant accomplishments for the projects reported during this period, are present in the following discussions.

\subsection{SITE REMEDIATION TECHNOLOGIES}

Task 1.1: Research on the Drain Enhanced Soil Flushing (DESF) for Organic Contaminants Removal project made reported progress in the area of enhanced fluid capture. Efficiency with the racer fluid extraction were increased from approximately $70 \%$ to $100 \%$ for the same time intervals. This increase is attributed to modifications in the drain layout configurations and with equipment modifications carried out at the end of the last reporting period. Preliminary work using different study soil mix ratios of sand and kaolinite clay has begun with identification of the soil properties.

Task 1.2: Work this period for the In situ Bioremediation of Organic Contaminants project continued with anaerobic and aerobic column studies. Parameters investigated under anaerobic conditions included TCE concentration, potential nitrogen limitations, methane feed level and response to short-term TCE shock. Aerobic experimentation investigated the concentration of a primary methanol substrate with a hydrogen peroxide electron donor acceptor. Experimental results showed increased TCE removal from $58 \%$ to $67 \%$ with increases in the methanol substrate concentrations. Operations under anaerobic conditions showed improved TCE removal with increases in methanol concentrations.

Task 1.3: Work performed on the Microbial Enrichment for Enhancing In Situ Biodegradation of Hazardous organic Wastes in Soil this period included: completing the gas chromatography analysis and data reduction of over 1,500 artificial mixed waste samples and experiments were performed on commercially available microbial inocula to evaluate biodegradation in study soils augmented with these inocula. The effect of nutrient amendment on bioremediaton was examined. It was observed that levels of nitrogen significantly increased biodegradation of individual hydrocarbon compounds. Monitoring of the artificial mixed organic waste study soil with inocula present and absent continued. Inoculum addition significantly increases soil respiration compared with uninoculated soil and soil amended with sterile inocula. Current efforts for the next reporting period will examine carbon-14 (14C) labeled substrates to develop radio respirometric assay of specific organic pollutants. 
Task 1.4: Progress on the Contaminant Movement Prediction in Permeable Subsurface soils project was limited to a literature search for information on subsurface groundwater contaminant flow prediction models. Tasks planned for the next reporting period center on development of a grid layout suitable for modeling the meso-scale experiments underway on the Drain Enhanced soil Flushing for Organic Contaminants Removal project, METC \#1.1.

Task 1.5: Progress on Development of a Standard Protocol and Barrier Design Model for In Situ Formed Barriers is separated into Chemical Grouting and Circulating Air Barrier (CAB).

Chemical Grouting: Development of standard testing procedure/protocol for evaluating various grouts as a barrier to contaminant plume migration is approximately 80\% complete. Trial grouting experiments have been underway using urethane gel and vinyl monomer grouts with encouraging results. Laboratory work performed this period dealt with completing the literature review for which a urethane gel and vinyl monomer grout were chosen for further testing. Immersion testing has been completed on both grouts to determine their reactivity in various harsh environments. Compression tests were performed on a number of disturbed grout and sand mixtures. Experimental results on the immersion testing showed that for both grouts exposure to air resulted in sample shrinkage and exposure to water resulted in swell. Exposure testing to sodium hydroxide discolored the grouts and resulted in structural deterioration.

Circulating Air Barrier (CAB): Development of the engineering drawings were completed and submitted to METC per procedural requirements and as of 7 April 95 no action on the drawings was taken. Additional literature searches have been performed to identify instruments for measuring and monitoring air humidity, soil moisture, and permeability. Testing on the sand-Packs have progressed to where consistent permeability measurements now vary approximately 3\%. Core tests on saturation and desaturation have been successfully performed and verified by measurements of porosity and permeability. Preparation of the SARS documentation is progressing and a draft operating Permit will be submitted to METC during the upcoming reporting period. 


\subsection{ADVANCED PRODUCT APPLICATIONS TESTING}

Task 2.1: Work this period on the Chemical Destruction of Chlorinated Organic compounds project resulted in the successful development of a synthetic procedure for preparing a monomer containing a sterically hindered triarylborcl functionality. An attempt to produce the corresponding polymer as a potential

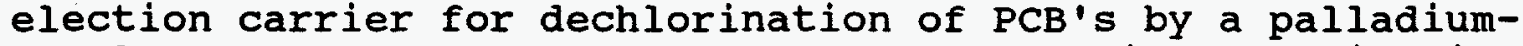
catalyzed process was performed. The resulting material is being characterized and a new compound containing two triarylboryl grouts has be synthesized. The results of these efforts are the development of a monomer for producing a polymeric material as an electron carrier for dechlorination of PCB's. Difficulties in the full characterization of the polymeric material are being worked out by employing new strategies to try and produce lower molecular weight oligomers to allow structural elucidation.

Task 2.2: Progress on the Continued Development of an Atmospheric Monitoring Mass spectrometry system project was limited to training undergraduate students on the use of the ion trap mass spectrometer. The students performed reproducibility experiments with the tandem mass spectrometry (MS/MS) for comparison with the ion trap mass spectrometer. The evaluations of MS/MS performance for the ethyl benzene-xylene separation have begun and will continue through to the next quarter.

Task 2.3: During this reporting period the Capture of Hazardous Waste Materials Utilizing Fluidization Coating Technology project did not report progress due to the funding delay.

Task 2.4: The Remediation of Hazardous Sites with Steam Reforming project reported that the experimental equipment was received and the system assembly was begun.

Task 2,5: The Environmental Pollution Control Devices Based on Novel Forms of Carbon project efforts included equipment assembly and testing. Experimentation on growing carbon nano-fibers onto a woven mat of graphite fibers showed the material to have a very large surface area (approximately $100 \mathrm{~m}^{2} / \mathrm{g}$ ). Evaluation of the test sample's ability to remove metals ions for an aqueous solution showed favorable results. The carbon nano-fiber mats showed removal efficiencies of $90 \%$, higher efficiencies are possible through the use of several mats. 


\subsection{INFORYATION SYSTEMS, PUBLIC POLICY, COMMUNITY OUTREACH, AND ECONOMICS}

Task 3.1: The Winfield Lock and Dam Remediation project reported that the air monitoring proposal was submitted to the Umbrella Committee for forwarding to ACF. The air monitoring proposed includes mass spectrometric methods for real-time volatiles monitoring and real-time dust monitoring. The citizens at winfield and the Corps were supportive. The Corps and ACF have agreed to ship the contaminated soil off-site for final disposition.

Task 3.2: Progress on the GIS-Based Infrastructure for Site Characterization and Remediation project this period included preparation of the NEPA documentation, and identification and acquisition of the computing hardware and software to support the Corps remediation needs.

Task 3.3: Efforts on the Small Business Support Program for this period focused on developing small business contacts and initiatives. During January visits were made to Manufacturing and Technology Conversion International Inc (MTCI) and spintek. MTCI is currently funded through the Agreement and several new tasks are being developed to initiate research with spintek. Collaboration with the Nilex Corporation, Denver, was initiated to investigate developing a field demonstration of the Drain Enhanced Soil Flushing project (Task 1.1). The newly formed and DOE HQ sponsored initiative to coordinate interagency use of site remediation technologies requested WVU support consisting of graduate students from engineering, computer systems, and journalism. Students have been referred and are being interviewed. Development for support of the small business incubator for site remediation technologies has begun with cooperation from the West Virginia High Tech Consortium.

Task 3.4 The Approach for Assessing Potential Voluntary Environmental Protection, Kanawha Valley Area work concerns investigation of the feasibility of establishing voluntary remediation programs in the Kanawha Valley, WV. A kick-off meeting was held at METC in March and to date no further progress has been reported. 


\section{TABLE OF CONTENTS}

Executive Summary

Project Titles with Principal Investigators

Administrative Summaries

Budget and Schedule Updates

Quarterly Technical Progress Reports

\subsection{IN-SITU REMEDIATION PROCESS DEVELOPMENT}

1.1 USE OF DRAIN ENHANCED SOIL FLUSHING (DESF) FOR ORGANIC CONTAMINANTS REMOVAL

1.2 IN-SITU BIOREMEDIATION OF CHLORINATED ORGANIC SOLVENTS

1.3 MICROBIAL ENRICHMENT FOR ENHANCING IN-SITU BIODEGRATION OF HAZARDOUS ORGANIC WASTES

1.4 CONTAMINANT MOVEMENT PREDICTION IN PERMEABLE SUBSURFACE SOILS

1.5 DEVELOPMENT OF STANDARD TEST PROTOCOLS \& BARRIER DESIGN MODELS FOR IN-SITU FORMED BARRIERS

\subsection{ADVANCED PRODUCT APPLICATIONS TESTING}

2.1 CHEMICAL DESTRUCTION OF CHLORINATED ORGANIC COMPOUNDS

2.2 CONTINUED DEVELOPMENT OF AN ATMOSPHERIC MONITORING MASS SPECTROMETRY SYSTEM

2.3 CAPTURE OF HAZARDOUS CHEMICAL WASTE MATERIALS UTILIZING FLUIDIZATION COATING TECHNOLOGY

2.4 SOIL DECONTAMINATION BY STEAM REFORMING

2.5 CARBON PRODUCTS FOR WASTE STREAM CLEANUP

$$
v i
$$




\section{TABLE OF CONTENTS (cont.)}

\subsection{INFORMATION SYSTEMS, PUBLIC POLICY,}

COMMUNITY OUTREACH AND ECONOMICS

3.1 WINFIELD LOCK AND DAM ASSISTANCE PROGRAM

3.2 A GIS BASED INFRASTRUCTURE FOR SITE CHARACTERIZATION AND REMEDIATION

3.3 SMALL BUSINESS SUPPORT PROGRAM

3.4 APPROACH FOR ASSESSING POTENTIAL VOLUNTARY ENVIRONMENTAL PROTECTION - KANAWHA RIVER AREA 


\section{PROJECT TITLES WITH PRINCIPAL INVESTIGATORS}

\subsection{IN-SITU REMEDIATION PROCESS DEVELOPMENT}

1.1 USE OF DRAIN ENHANCED SOIL FLUSHING (DESF)

FOR ORGANIC CONTAMINANTS REMOVAL

M. Gabr, Dept. of Civil \& Environmental Eng.

1.2 IN-SITU BIOREMEDIATION OF CHLORINATED ORGANIC SOLVENTS

W. Sack and P. Carriere, Dept. of Civil \& Environmental Eng.

A. Shiemke, Dept. of Biochemistry

1.3 MICROBIAL ENRICHMENT FOR ENHANCING IN-SITU BIODEGRATION OF HAZARDOUS ORGANIC WASTES

A. Sexstone, Dept. of Plant \& Soil science

1.4 CONTAMINANT MOVEMENT PREDICTION IN PERMEABLE SUBSURFACE SOILS

H. Bilgesu and S. Ameri, Dept. of Petroleum Eng.

1.5 DEVELOPMENT OF STANDARD TEST PROTOCOLS \& BARRIER DESIGN MODELS FOR IN-SITU FORMED BARRIERS

C. Black, NRCCE,

M. Gabr, Dept. of Civil \& Environmental Eng.,

S. Ameri \& K. Aminian, Dept. of Petroleum Eng.

\subsection{ADVANCED PRODUCT APPLICATIONS TESTING}

2.1 CHEMICAL DESTRUCTION OF CHLORINATED ORGANIC COMPOUNDS

K. Wang, Dept. of Chemistry

2.2 CONTINUED DEVELOPMENT OF AN ATMOSPHERIC MONITORING MASS SPECTROMETRY SYSTEM

F. King, Dept. of Chemistry 
2.3 CAPTURE OF HAZARDOUS CHEMICAL WASTE MATERIALS UTILIZING FLUIDIZATION COATING TECHNOLOGY

R. Turton, Dept. of Chemical Eng.

2.4 SOIL DECONTAMINATION BY STEAM REFORMING

R. Lovett, NRCCE

2.5 CARBON PRODUCTS FOR WASTE STREAM CLEANUP

C. Irwin, NRCCE and J. Zondlo, Dept. of Chemical Eng.

\subsection{INFORMATION SYSTEMS, PUBLIC POLICY,} COMMUNITY OUTREACH AND ECONOMICS

3.1 WINFIELD LOCK AND DAM ASSISTANCE PROGRAM

R. Lovett, NRCCE

3.2 A GIS BASED INFRASTRUCTURE FOR SITE CHARACTERIZATION AND REMEDIATION

E. Cook, Dept. of Civil \& Environmental Eng., and

J. Hooper, Marshall Univ.

3.3 SMALL BUSINESS SUPPORT PROGRAM

E. Cook, Dept. of Civil \& Environmental Eng.

3.4 APPROACH FOR ASSESSING POTENTIAL VOLUNTARY ENVIRONMENTAL PROTECTION - KANAWHA RIVER AREA

R. Lovett, NRCCE 


\section{Administrative \\ Summary}

\section{Background}

West Virginia University (WVU) and the U.S. Department of Energy Morgantown Energy Technology Center (DOE/METC) entered into a Cooperative Agreement on August 29, 1992 titled "Decontamination Systems Information and Research Programs" (DOE Instrument No.: DE-FC21-92MC29467). Requirements stipulated by the Agreement require WVU to submit Technical Progress reports on a quarterly basis. This report contains the efforts of the fourteen research projects comprising the Agreement for the period January 1 to December 31, 1995.

\section{Administrative Issues}

The WVU College of Engineering, Department of Civil and Environmental Engineering assumed the lead agency role in administration of the Agreement replacing the National Research Center for Coal and Energy, Environmental Technology Division. Since this change occurred in November 1994, the transition and responsibilities between these organizations is still being worked out.

\section{Project Variances, Accomplishments, and Problems}

As a result of the funding delay with the Agreement schedule delays have occurred. Projects affected by these delays will be monitored for progress and if necessary, recovery schedules will be prepared. 


\section{ADMINISTRATIVE BUDGETS}




\section{Overall Summary of REGULAR Budgets \\ On a CASH Basis for period ending 3/31/95 - WVU Cooperative Agreement}

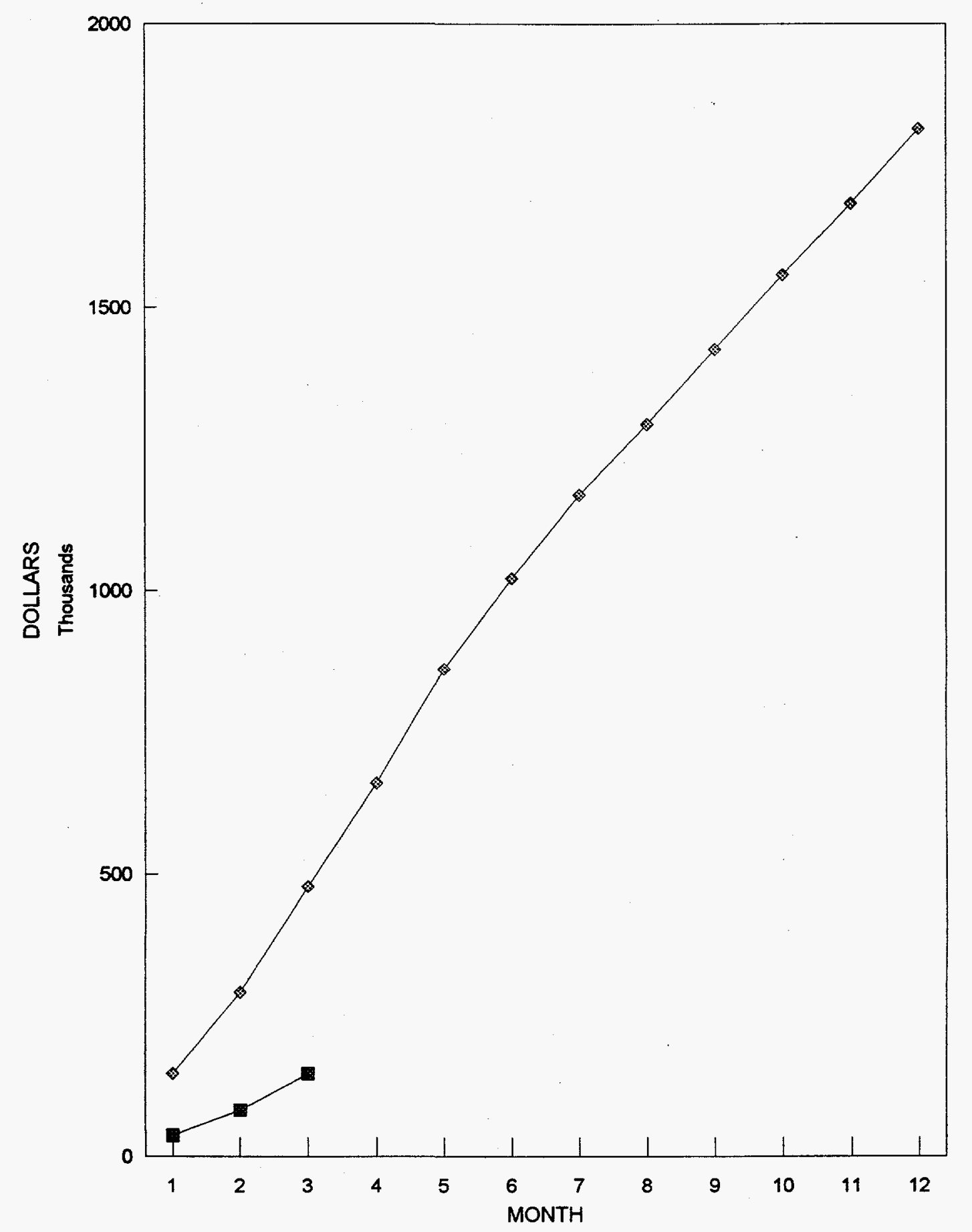

ACTUAL EXPENDITURES PLANNED EXPENDITURES 


\begin{tabular}{|c|c|c|c|c|c|c|c|c|c|c|c|c|c|c|c|c|}
\hline $\begin{array}{l}\text { MEI } \\
\text { Tast }\end{array}$ & PROJECT TITLE & PLANNED & $\begin{array}{c}1 \\
\text { JAN } \\
\end{array}$ & $\stackrel{2}{2}$ & $\begin{array}{c}3 \\
\text { MARCH }\end{array}$ & $\begin{array}{c}4 \\
\text { APRIL }\end{array}$ & $\begin{array}{c}5 \\
\text { MAY } \\
\end{array}$ & $\begin{array}{l}6 \\
\text { JUNE } \\
\end{array}$ & $\begin{array}{l}7 \\
\text { JULY }\end{array}$ & $\begin{array}{c}8 \\
\text { AUG } \\
\end{array}$ & $\begin{array}{c}9 \\
\text { SEPT }\end{array}$ & $\begin{array}{c}10 \\
\text { OCT } \\
\end{array}$ & $\begin{array}{c}11 \\
\text { NoV }\end{array}$ & $\begin{array}{c}12 \\
\text { DEC }\end{array}$ & $\begin{array}{l}\text { PLANNED } \\
\text { TOTALS }\end{array}$ & 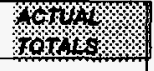 \\
\hline 1.1 & $\begin{array}{l}\text { Use of Drain Enhanced Soil Flushing } \\
\text { (DESF) for Organic Contaminants Rernoval }\end{array}$ & $\begin{array}{l}\text { PLANNED } \\
\text { OCHOF }\end{array}$ & \%, & 4,854 & 12,854 & 6.654 & 6.374. & 5,502 & 14,002 & 7,718 & 10.600 & 11,100 & 10,890 & 10,600 & \multicolumn{2}{|c|}{106,000} \\
\hline 1.2 & $\begin{array}{l}\text { In-Situ Bioremediation of Chlorinated } \\
\text { Organic Solvents }\end{array}$ & PLANNED & $\%$ & \% & 7,347 & 7,347 & 7,347 & 12,707 & 9,332 & 13,304 & 9,578 & 9,578 & 9,578 & 9.578 & \multicolumn{2}{|c|}{95,694} \\
\hline 1.3 & $\begin{array}{l}\text { Microbial Enrichment tor Enhancing In-Situ } \\
\text { Biodegradation of Hazardous Organic Wastes }\end{array}$ & PLANNED & 4,364 & 4,364 & 6,364 & 4,364 & 4,364 & 8,244 & 8,244 & 3,879 & 8,819 & 8,819 & 8,819 & 8,819 & \multicolumn{2}{|c|}{79,465} \\
\hline 1.4 & $\begin{array}{l}\text { Contaminant Movement Prediction in } \\
\text { Permeable Subsurface Soils }\end{array}$ & $\begin{array}{l}\text { PLANNED } \\
\text { KOAW }\end{array}$ & 0 & 0 & 0 & mo & 5.541 & 6,399 & 1,773 & 1,773 & \%,997 & \%.454 & 4,083 & \%.224 & \multicolumn{2}{|c|}{32,246} \\
\hline 1.5 & $\begin{array}{l}\text { Development of Standard Test Protocols \& } \\
\text { Barrier Dsgn Models for In-Situ Frmd Barriers }\end{array}$ & $\begin{array}{l}\text { PLANNED } \\
\text { OANALF. }\end{array}$ & 80,700 & 79,175 & 94,175 & 79,175 & 79,175 & 30,616 & 22,827 & 28,438 & 13,707 & 13.707 & \%.,094 & 17,053 & \multicolumn{2}{|c|}{ 落, } \\
\hline \multicolumn{17}{|c|}{ 2.0 ADVANCED PRODUCT APPLICATIONS TESTING } \\
\hline 2.1 & $\begin{array}{l}\text { Chemical Destruction of Chlorinated Organic } \\
\text { Compounds }\end{array}$ & $\begin{array}{l}\text { PLANNED } \\
\text { OHUAK }\end{array}$ & 2.941 & 2,941 & 2,941 & 4,300 & 8,207 & 8,636 & 6,087 & 5,387 & 6,567 & 6.567 & 6,567 & 6,567 & \multicolumn{2}{|c|}{67,709} \\
\hline 2.2 & $\begin{array}{l}\text { Continued Development of an Atmospheric } \\
\text { Monitoring Mass Spectrometry System }\end{array}$ & PLANNED & 8 & 0 & 0 & 900 & 8,431 & 11,758 & 10,208 & 6,148 & 9.936 & 9,936 & 9,836 & 7,865 & \multirow{2}{*}{\multicolumn{2}{|c|}{$\begin{array}{l}75,019 \\
30,593 \\
\text { } \\
\text { \% }\end{array}$}} \\
\hline 2.3 & $\begin{array}{l}\text { Capture of Haz Chem Waste Materials } \\
\text { Utilizing Fluidization Coating Technology }\end{array}$ & $\begin{array}{l}\text { PLANNED } \\
\text { KNA } / \text { I }\end{array}$ & $\%$ & $\%$ & $\%$ & 960 & 5,141 & 3.513 & \%,513 & 3.513 & 3.124 & \%,524 & 4,182 & 3.124 & & \\
\hline 2.4 & Soil Decontamination by Steam Reforming & $\begin{array}{l}\text { PLANNED } \\
\text { ACTUAL }\end{array}$ & - See Exten & d Budget & & & & & & & & & & & \multirow{2}{*}{\multicolumn{2}{|c|}{184,490}} \\
\hline 2.5 & Carbon Products for Waste Stream Cleanup & PLANNED & 9.656 & 9,656 & 14,463 & 14,463 & 16,044 & 16,044 & 23,674 & 8,070 & 18,105 & 18,105 & 18,105 & 18,105 & & \\
\hline \multicolumn{17}{|c|}{ 3.0 INFORMATION SYSTEMS, PUBLIC POLICY, COMMUNITY OUTREACH AND ECONOMICS } \\
\hline 3.1 & Winfield Lock and Dam Assistance Program & $\begin{array}{l}\text { PLANNED } \\
\text { \% } / \text { H } \% \text {. }\end{array}$ & $\begin{array}{l}7,122 \\
0 \% 88\end{array}$ & $\begin{array}{l}7.122 \\
\% 856\end{array}$ & $\begin{array}{l}7.122 \\
\% 21 \%\end{array}$ & 7,122 & 7.122 & 7,122 & 7,122 & 6,266 & 6,266 & 6,266 & 6,266 & 6,266 & \multicolumn{2}{|c|}{ \%1,180 } \\
\hline 3.2 & $\begin{array}{l}\text { A GIS Based Infrastructure for Site } \\
\text { Characterization and Romediation }\end{array}$ & $\begin{array}{l}\text { PLANNED } \\
C H \% \text {. }\end{array}$ & $\begin{array}{l}13,508 \\
2,0 \%\end{array}$ & $\begin{array}{l}13,508 \\
10 \% 4 \%\end{array}$ & $\begin{array}{l}13.508 \\
1068\end{array}$ & 29,683 & 26,683 & 24,324 & 14,370 & 14.370 & 14,370 & 14,370 & 14,370 & 14,370 & \multirow{2}{*}{\multicolumn{2}{|c|}{$\begin{array}{l}207,434 \\
94,860\end{array}$}} \\
\hline 3.3 & Small Business Support Program & $\begin{array}{l}\text { PLANNED } \\
\text { KOWHK }\end{array}$ & $\begin{array}{l}7,905 \\
\% 7005\end{array}$ & 7,905 & $\begin{array}{l}7,905 \\
\% 90 \%\end{array}$ & 7,905 & 7.905 & 7,905 & 7,905 & 7,905 & 7,905 & 7,905 & 7,905 & 7.905 & & \\
\hline 3.4 & $\begin{array}{l}\text { Approach for Assessing Potential Voluntary } \\
\text { Env Protection - Kanawha River Area }\end{array}$ & $\begin{array}{l}\text { PLANNED } \\
\text { ACTUAL }\end{array}$ & ** See exten & d budget & & & & & & & & & & & & \\
\hline
\end{tabular}

CONTINUED 


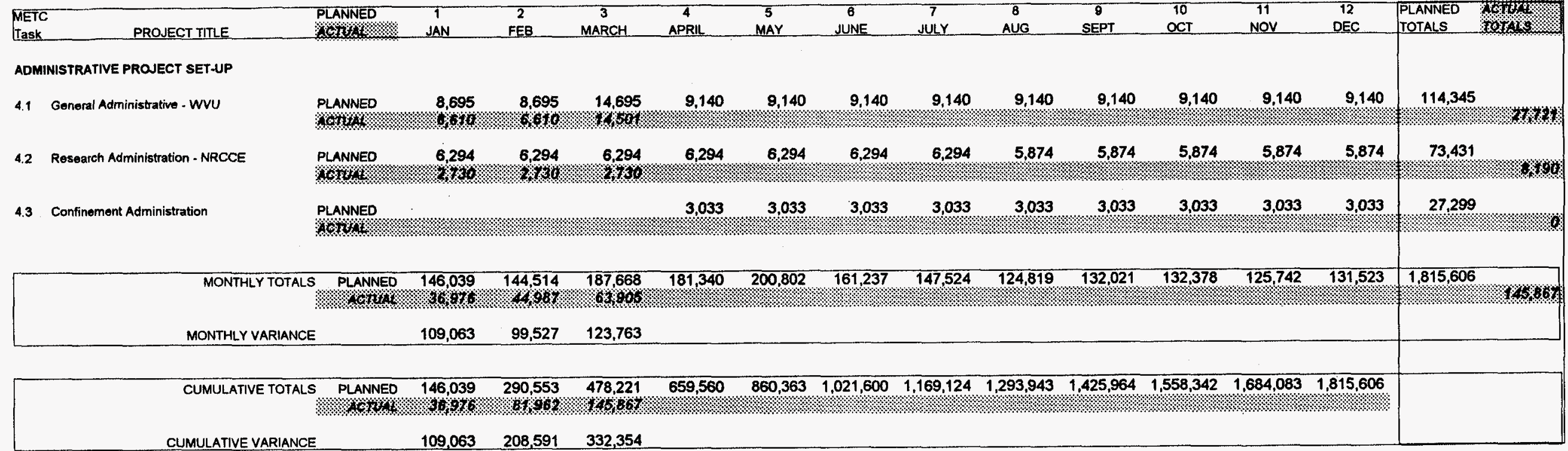




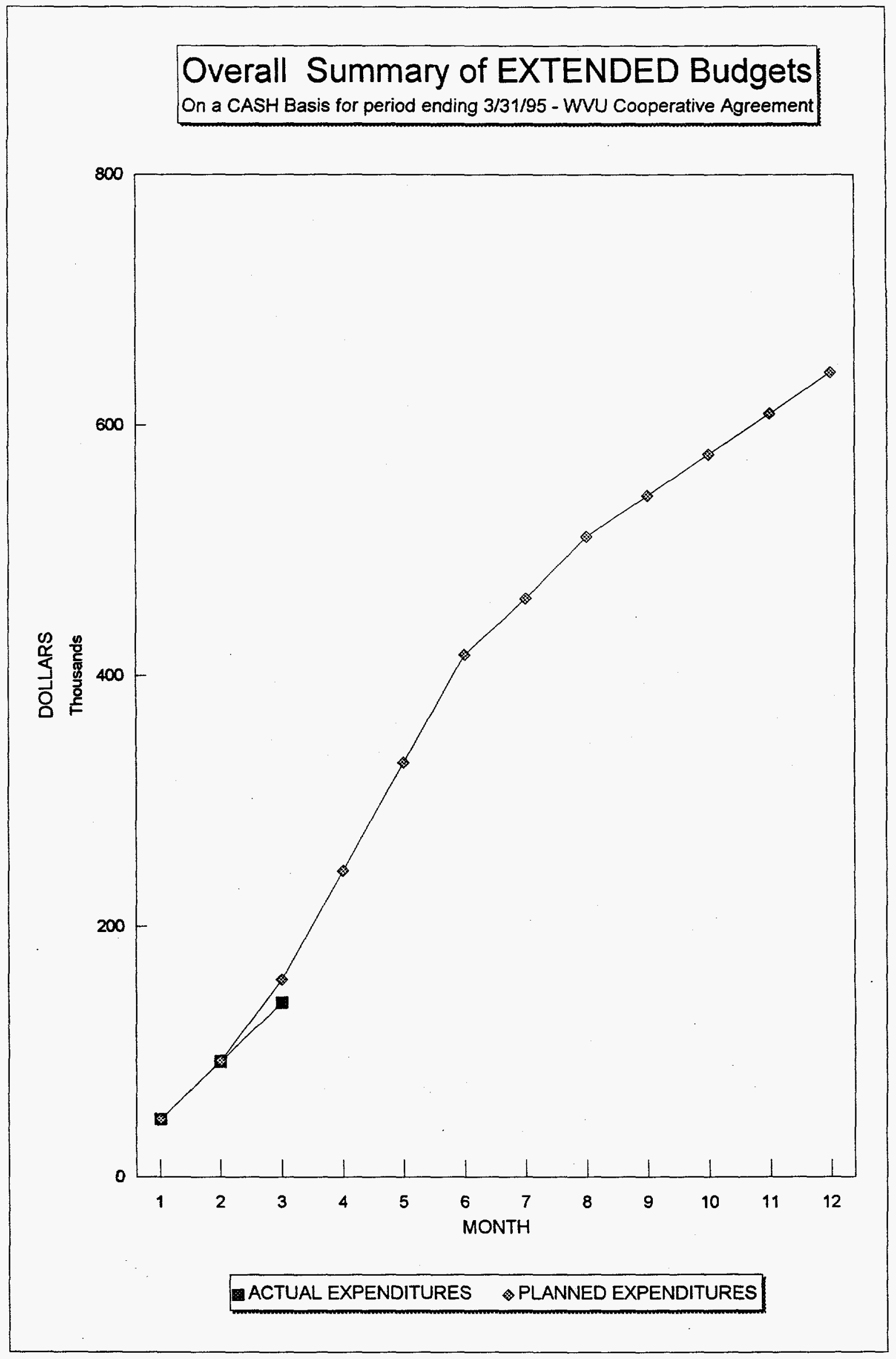




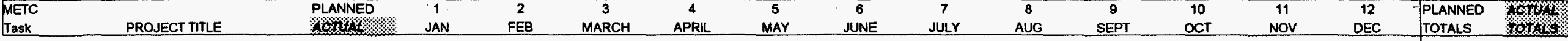

1.0 IN-SITU REMEDIATION PROCESS DEVELOPMENT

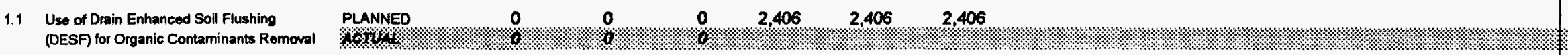

12 In-Situ Bioremediation of Chlorinated Organic Solvents

PLANMED $\quad 0 \quad 004044$

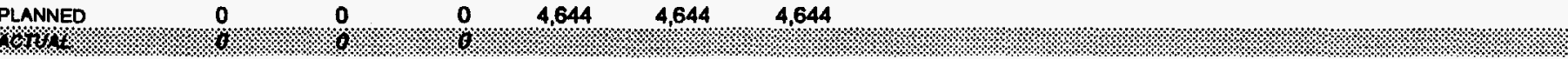

7218

\%.

13,932

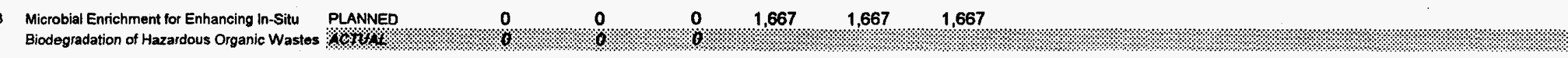

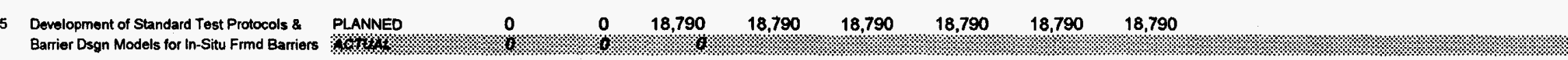

2.0 ADVANCED PRODUCT APPLICATIONS TESTINO

2.1 Chemical Destruction of Chlorinated Organic PLANNED

Compounds

PLANNE

4 Soil Decontamination by Steam Reforming

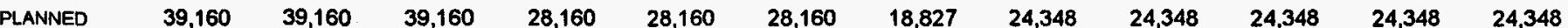

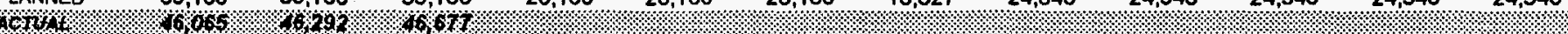

112,739

\% $\ldots$

8.557

PLANNED

25 Carbon Products for Waste Stream Cleanup

3.0 INFORMATION SYSTEMS, PUBLIC POLICY, COMMUNITY OUTREACH AND ECONOMICS

3.4 Approach for Assessing Potential Voluntary

Env Protection - Kanawha River Area

$\begin{array}{lll}7.183 & 7.183 & 7.183\end{array}$

$183 \quad 7,183$

$7,183 \quad 7.183$

6,206

8,431

8,431

8,431

8,431

OTHER EXTENDED BUDGETS

MC-7 Development of Organic Sensors

PLANNED $00 \%$ \%

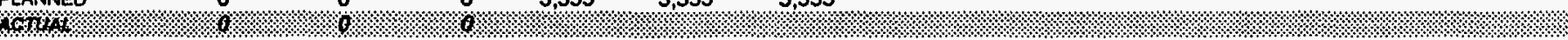

MC-1 Improved Computer Model to Predict VOC Recovery

PLANED

\begin{tabular}{|c|c|c|c|c|c|c|c|c|c|c|c|c|c|c|}
\hline MONTHLY TOTALS & $\begin{array}{l}\text { PLANNED } \\
\text { KOWW }\end{array}$ & $\begin{array}{r}46,343 \\
66 \mathrm{dog}\end{array}$ & $\begin{array}{l}46,343 \\
16,8 \%\end{array}$ & 65,133 & 86,319 & 86,319 & 86,319 & 44.800 & 49,344 & 32,779 & 32,779 & 32.779 & 32.779 & 642,035 \\
\hline MONTHLY VARIANCE & & 278 & 51 & 18,456 & & & & & & & & & & \\
\hline CUMULATIVE TOTALS & PLANNED & $\begin{array}{l}46,343 \\
10,065\end{array}$ & 92,686 & $\begin{array}{l}157,819 \\
150803 \%\end{array}$ & 244,137 & 330,456 & 416.774 & 461,574 & 510,918 & 543,697 & 576,477 & 609.256 & 642,035 & \\
\hline
\end{tabular}


GENERAL ADMINISTRATIVE BUDGET

PRINCIPAL INVESTIGATOR: Dr. E.E. Cook

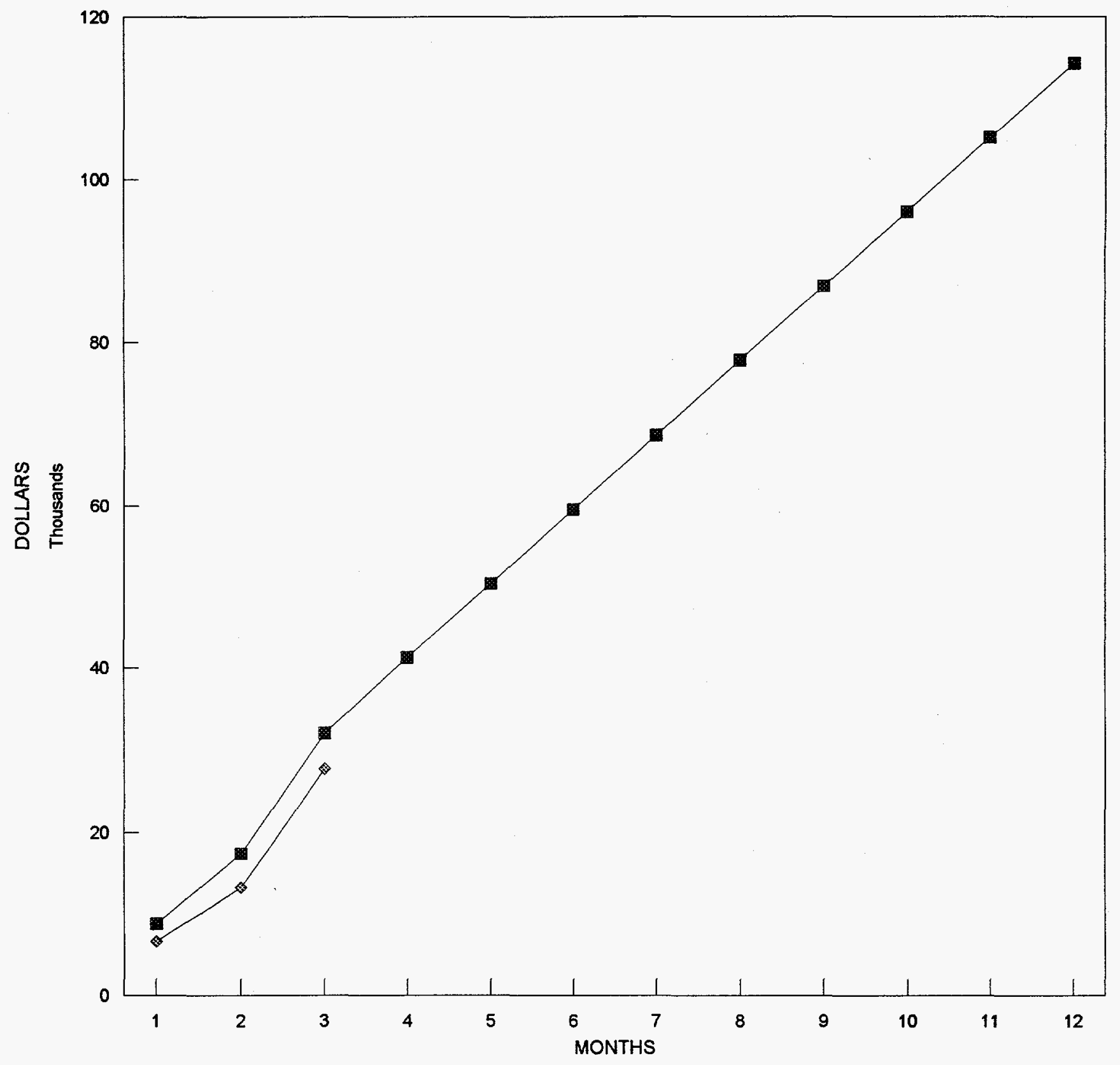

PLANNED SPENDING ACTUAL SPENDING 


\section{PROJECT: General Administrative Budget}

PRINCIPAL INVESTIGATIOR: E.E. CoOK

PERIOD ENGING: $3 / 31 / 95$

\begin{tabular}{|c|c|c|c|c|c|c|c|c|c|c|c|c|c|c|c|}
\hline DESCRIPTION & $\begin{array}{l}\text { PLANNED } \\
\text { ACTUAL }\end{array}$ & $\begin{array}{c}1 \\
\text { JAN }\end{array}$ & $\stackrel{2}{\mathrm{FEB}}$ & $\stackrel{3}{M}$ & $\begin{array}{c}4 \\
\text { APRIL }\end{array}$ & $\begin{array}{c}5 \\
\text { MAY }\end{array}$ & $\begin{array}{c}6 \\
\text { JUNE }\end{array}$ & $\begin{array}{l}7 \\
\text { JULY }\end{array}$ & $\stackrel{8}{A \cup G}$ & $\stackrel{9}{9}$ & $\begin{array}{c}10 \\
\text { OCT }\end{array}$ & $\begin{array}{c}11 \\
\text { NOV }\end{array}$ & $\begin{array}{c}12 \\
\text { DEC }\end{array}$ & $\begin{array}{l}\text { PROJECTED } \\
\text { TOTALS }\end{array}$ & $\begin{array}{l}\text { ACTUAL } \\
\text { TOTALS }\end{array}$ \\
\hline \multicolumn{16}{|l|}{ SALARIES } \\
\hline $\begin{array}{l}\text { Director, } \\
\text { Asst., Sec }\end{array}$ & $\begin{array}{l}\text { planned } \\
\text { actual }\end{array}$ & $\begin{array}{l}3,583 \\
3,583\end{array}$ & $\begin{array}{l}3,583 \\
3,583\end{array}$ & $\begin{array}{l}3,583 \\
3,583\end{array}$ & 3,583 & 3,583 & 3,583 & 3,583 & 3,583 & 3,583 & 3,583 & 3,583 & 3,583 & $\$ 42,999$ & $\$ 10,749$ \\
\hline \multicolumn{16}{|l|}{ BENEFITS } \\
\hline $\begin{array}{l}29 \% \text { of } \\
\text { Salaries }\end{array}$ & $\begin{array}{l}\text { planned } \\
\text { actual }\end{array}$ & $\begin{array}{l}1,039 \\
1,039\end{array}$ & $\begin{array}{l}1,039 \\
1,039\end{array}$ & $\begin{array}{l}1,039 \\
1,039\end{array}$ & 1,039 & 1,039 & 1,039 & 1,039 & 1,039 & 1,039 & 1,039 & 1.039 & 1,039 & $\$ 12,470$ & $\$ 3,117$ \\
\hline \multicolumn{16}{|l|}{ EQUIPMENT } \\
\hline $\begin{array}{l}\text { Computers } \\
\text { and misc. }\end{array}$ & $\begin{array}{l}\text { planned } \\
\text { actual }\end{array}$ & 0 & 0 & $\begin{array}{l}6,000 \\
6,224\end{array}$ & 444 & 444 & 444 & 444 & 444 & 444 & 444 & 444 & 444 & $\$ 10,000$ & $\$ 6,224$ \\
\hline \multicolumn{16}{|l|}{ OTHER } \\
\hline $\begin{array}{l}\text { Travel, phone, } \\
\text { xerox }\end{array}$ & $\begin{array}{l}\text { planned } \\
\text { actual }\end{array}$ & 333 & 333 & $\begin{array}{r}333 \\
10\end{array}$ & 333 & 333 & 333 & 333 & 333 & 333 & 333 & 333 & 333 & $\$ 4,000$ & $\$ 10$ \\
\hline Supplies & $\begin{array}{l}\text { planned } \\
\text { actual }\end{array}$ & 1,125 & 1,125 & $\begin{array}{l}1,125 \\
1,156\end{array}$ & 1,125 & 1,125 & 1,125 & 1,125 & 1,125 & 1,125 & 1,125 & 1.125 & 1.125 & $\$ 13,500$ & $\$ 1,156$ \\
\hline \multicolumn{16}{|l|}{ INDIRECT COSTS } \\
\hline $\begin{array}{l}43 \% \text { of exp } \\
\text { Exc Equip }\end{array}$ & $\begin{array}{l}\text { planned } \\
\text { actual }\end{array}$ & $\begin{array}{l}2,615 \\
1,987\end{array}$ & $\begin{array}{l}2,615 \\
1,987\end{array}$ & $\begin{array}{l}2,615 \\
2,489\end{array}$ & 2,615 & 2,615 & 2,615 & 2,615 & 2,615 & 2,615 & 2,615 & 2,615 & 2,615 & $\$ 31,377$ & $\$ 6,464$ \\
\hline 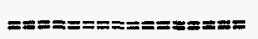 & $== \pm=z= \pm=0$ & $==== \pm$ & $=====x=$ & $==x====$ & $== \pm=x==0$ & $== \pm== \pm=$ & $===== \pm==$ & $=== \pm==x=$ & $== \pm===$ & $==x===x==$ & $== \pm===$ & $== \pm=x==$ & $=\leq====$ & $z===z==\pi=0$ & $z== \pm=8$ \\
\hline $\begin{array}{l}\text { PLANNED TOTALS: } \\
\text { PER MONTH }\end{array}$ & & 8,695 & 8,695 & 14,695 & 9,140 & 9,140 & 9,140 & 9,140 & 9,140 & 9,140 & 9,140 & 9,140 & 9,140 & $\$ 114,345$ & \\
\hline $\begin{array}{l}\text { ACTUAL TOTALS: } \\
\text { PER MONTH } \\
\text { =E= }\end{array}$ & 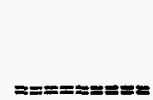 & 6,610 & 6,610 & 14,501 & $= \pm= \pm x$ & $:===$ & $y===0$ & $===$ & $==$ & $==$ & 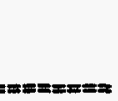 & $=0$ & 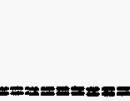 & $s=x=$ & $\begin{array}{l}\$ 27,720 \\
\$ z=x===\end{array}$ \\
\hline $\begin{array}{l}\text { CUMULATIVE } \\
\text { PLANNED TOTALS }\end{array}$ & & 8,695 & 17,391 & 32,086 & 41,226 & 50,366 & 59,506 & 68,646 & 77,786 & 86,926 & 96,065 & 105,205 & 114,345 & $\$ 114,345$ & \\
\hline $\begin{array}{l}\text { CUMULATIVE } \\
\text { ACTUAL TOTALS }\end{array}$ & & 6,610 & 13,219 & 27,720 & & & & & & & & & & & $\$ 27,720$ \\
\hline UNDER BUDGET & & $\$ 2,086$ & $\$ 4,172$ & $\$ 4,366$ & & & & & & & & & & & \\
\hline
\end{tabular}


NRCCE RESEARCH ADMINISTRATIVE BUDGET

Research Admin. Expenses

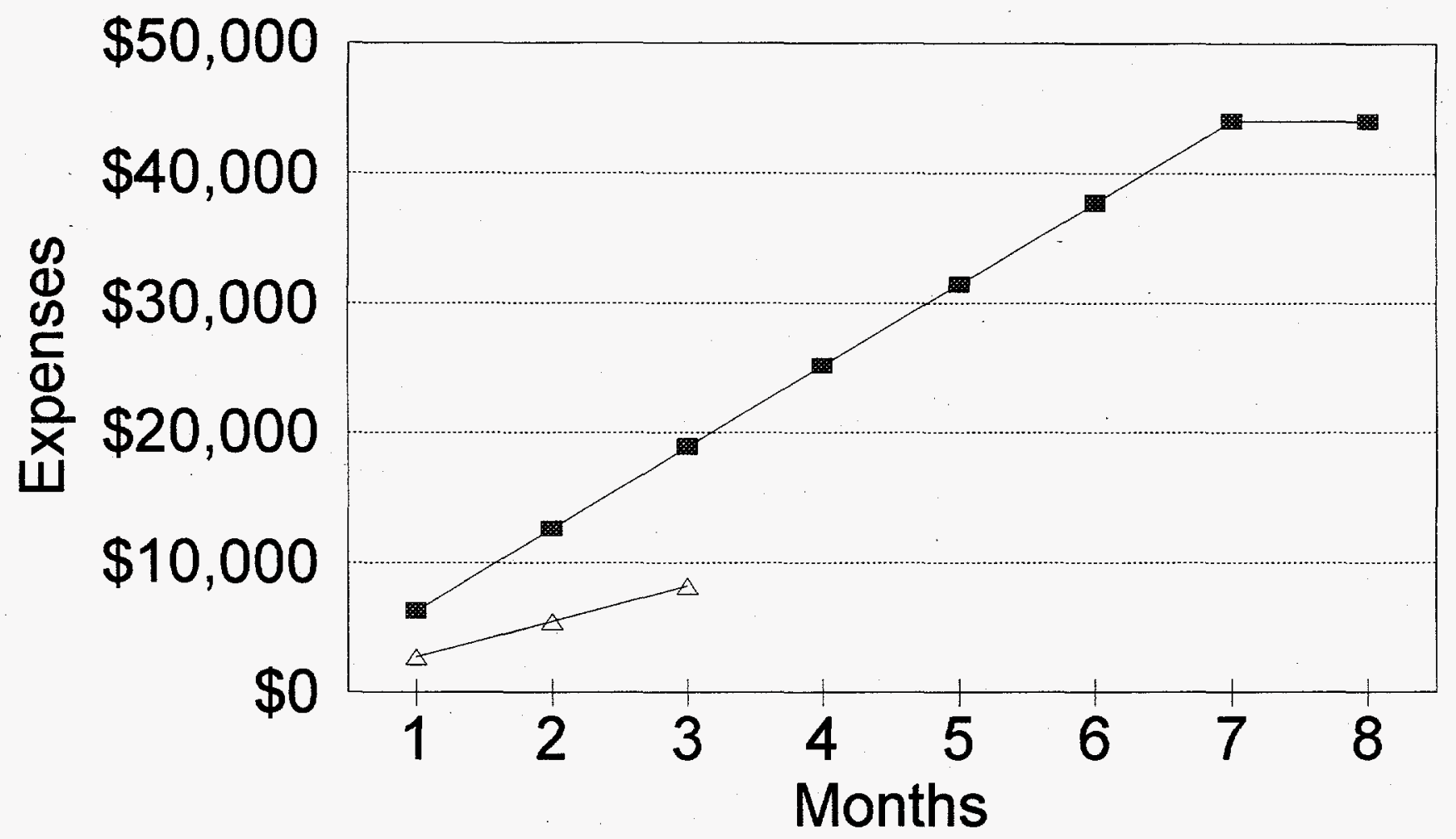

- Planned spending $\triangle$ Actual spending 
Administrative

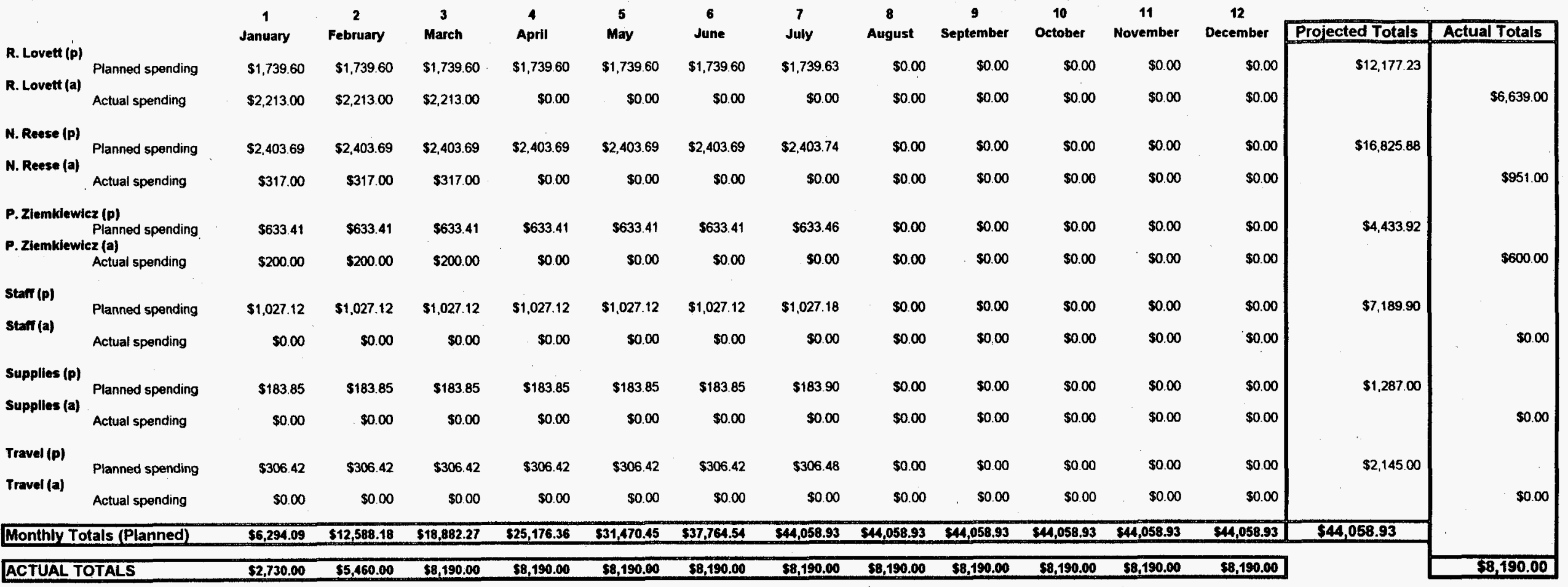

THIS BUDGET REFLECTS THE AWARD OF 60\% OF THE TOTAL PROJECTS BUDGET (awarded 3/43/95). 


\section{Research Administration}

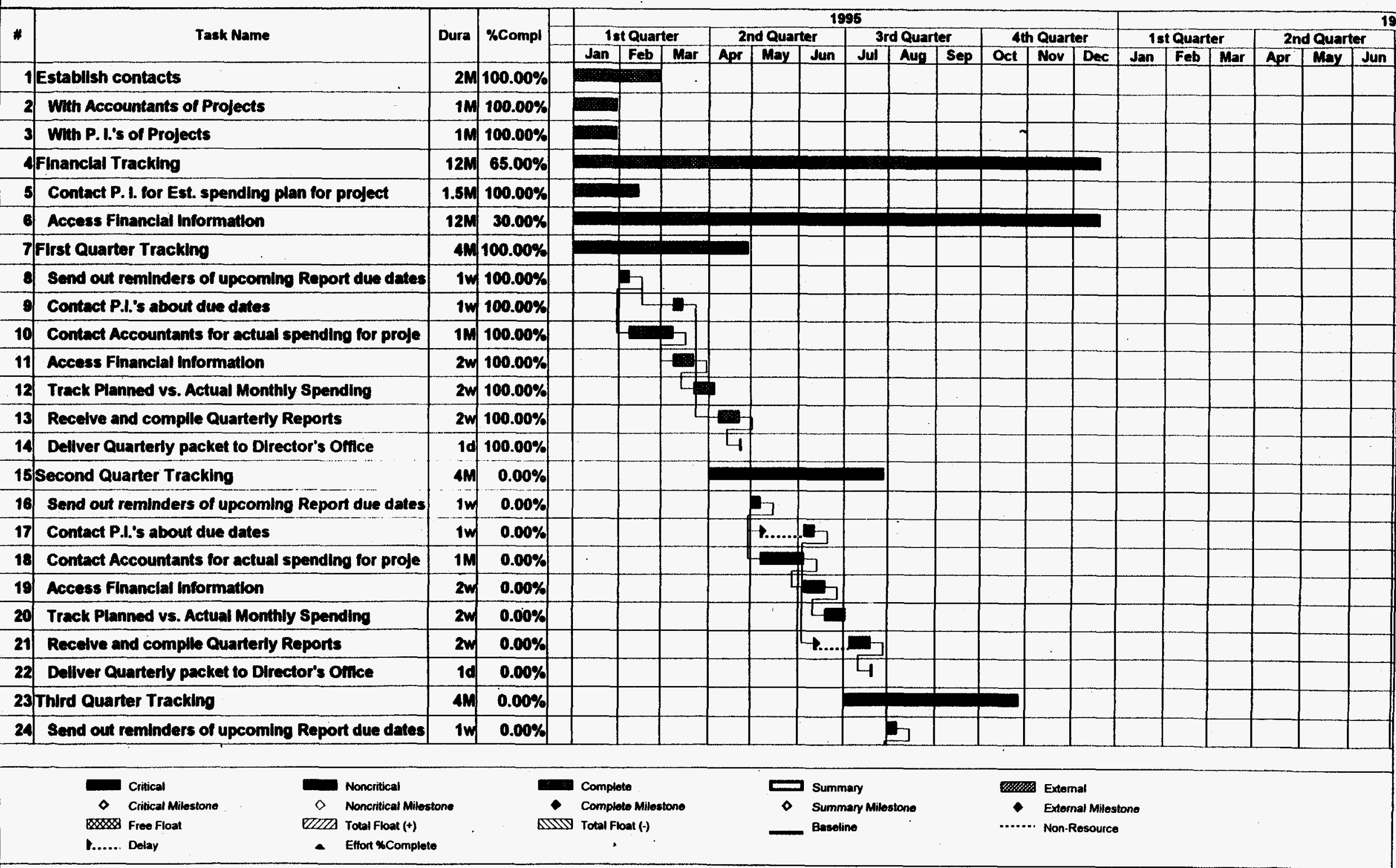

Page \# 1 


\section{Research Administration}

25 Contact P.I.'s about due dates

26 Contact Accountants for actual spending for proje

27 Access Financial Information

28 Track Planned vs. Actual Monthly Spending

29 Recelve and complle Quarterly Reports

30 Dellver Quarterly packet to Director's Omce

31 Final Quarter Tracking

32 Send out reminders of upcoming Report due dates

33 Contact P.I.'s about due dates for Final Report

34. Contact Accountants for actual spending for proje

36. Access Financial Information

36. Track Planned vs. Actual Monthly Spending

37 Contact P.I.'s about due dates for Final Report

38 Receive and complle Final Reports

39 Dellver Final Reports to Director's Office

40 Overall Work Completed

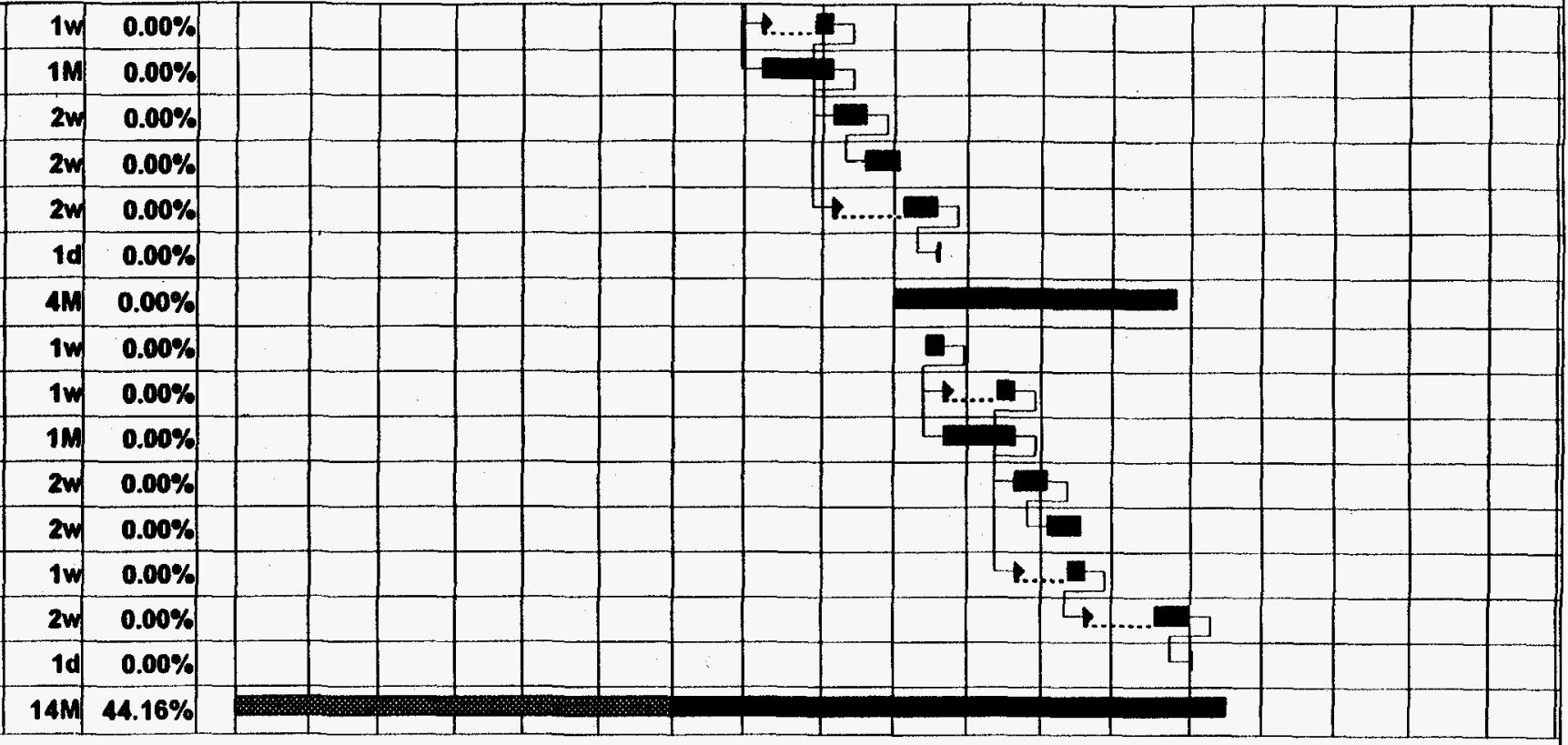

$$
\text { + }
$$

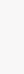

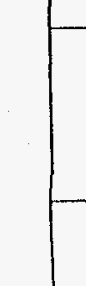



REGULAR BUDGETS

$-25-$ 



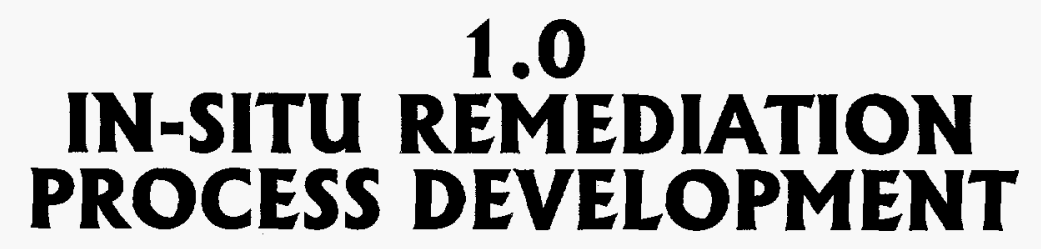

$-27-$ 
$-28-$ 
METC TASK \#: 1.1: Use of Drain Enhanced Soil Flushing (DESF) for Organic Contaminants Removal

\section{MC- 2a Expenses Enhanced Soil Flushing}

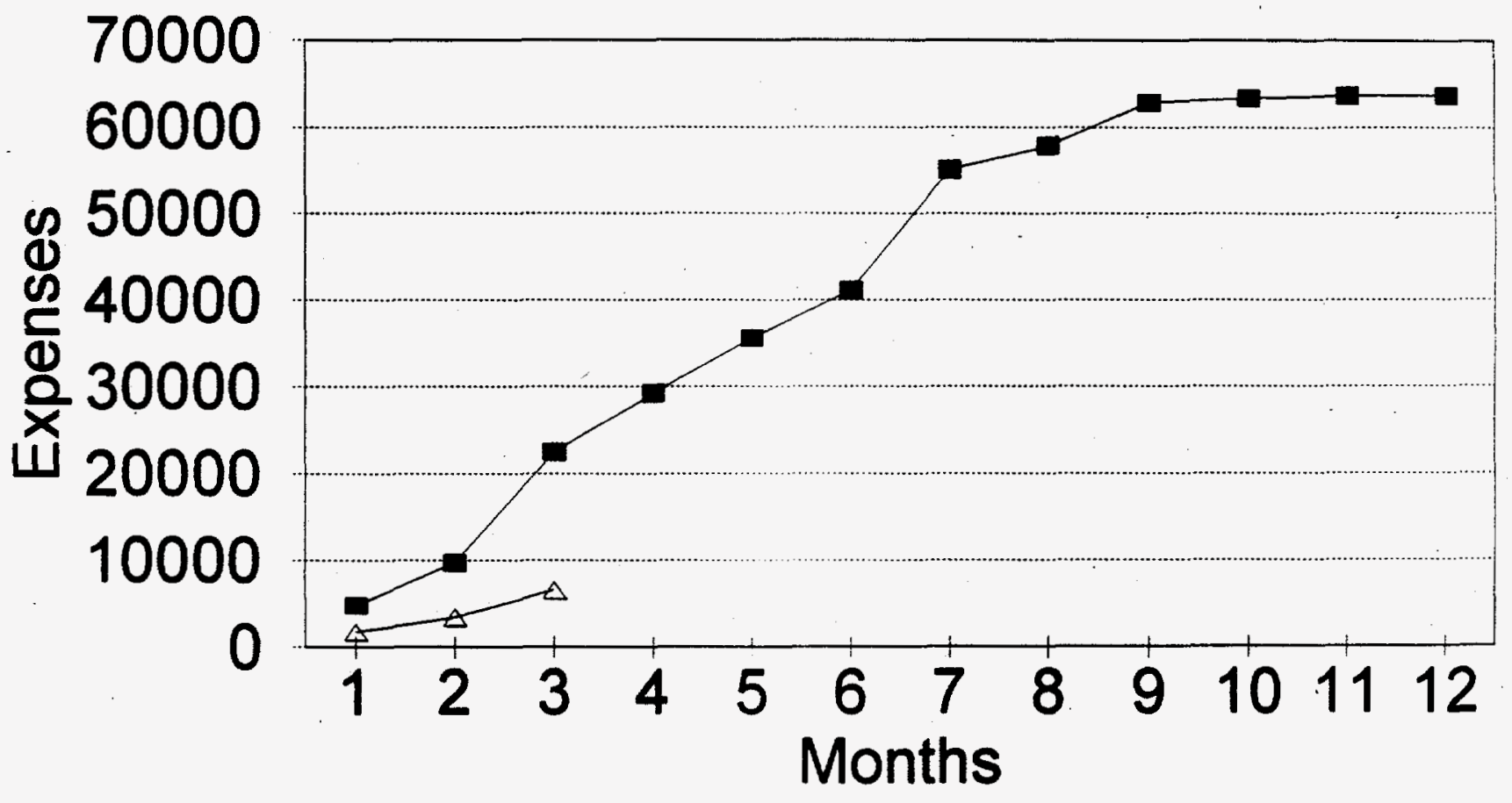

- - Planned spending - Actual spending 


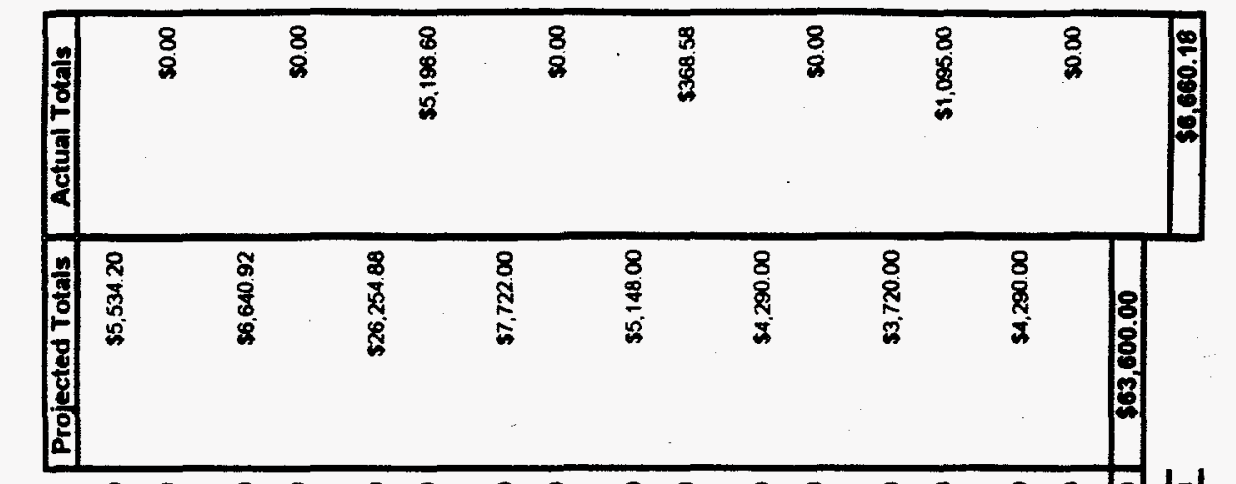

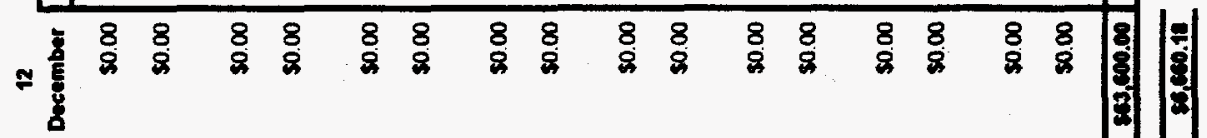

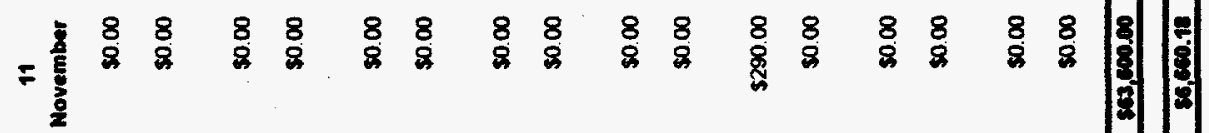

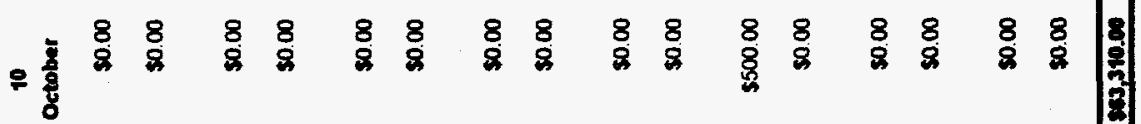

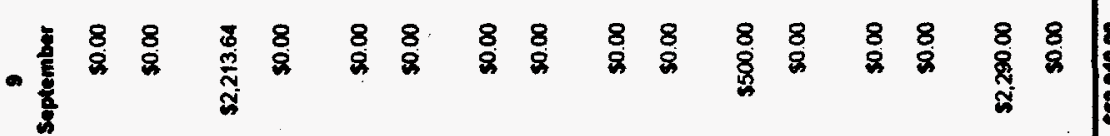

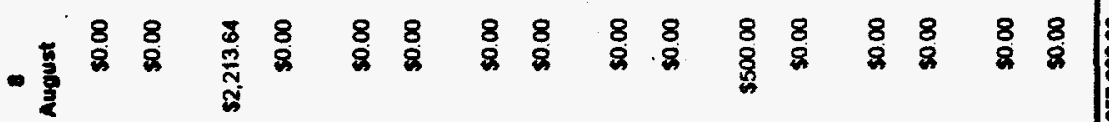

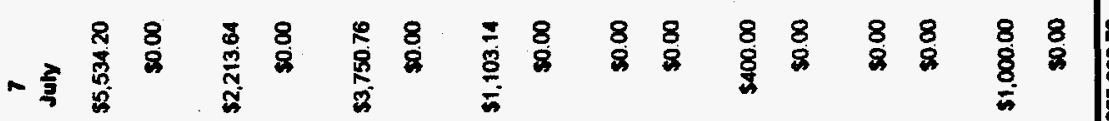
-

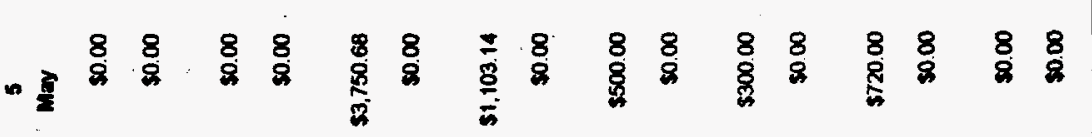

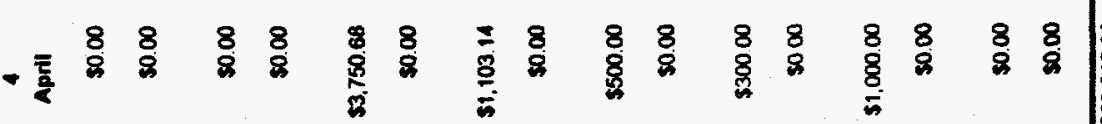
-

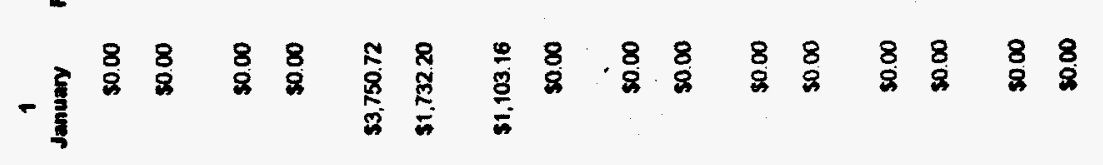


METC TASK \#: 1.1

\section{Drain-Enhanced Soil Flushin}

\begin{tabular}{|c|c|c|c|c|c|c|c|c|c|c|c|c|c|c|c|c|c|c|c|c|c|c|c|c|c|}
\hline \multirow{3}{*}{$*$} & \multirow{3}{*}{ Task Mame } & \multirow{3}{*}{ Dura } & \multirow{3}{*}{ Xcompl } & \multicolumn{12}{|c|}{1995} & \multicolumn{10}{|c|}{1996} \\
\hline & & & & \multicolumn{3}{|c|}{ Ist Quarter } & \multicolumn{3}{|c|}{ 2nd Quarter } & \multicolumn{3}{|c|}{ 3rd Quarter } & \multicolumn{3}{|c|}{ Ath Quarter } & \multicolumn{3}{|c|}{ Ist Quarter } & \multicolumn{3}{|c|}{ 2nd Quarter } & \multicolumn{3}{|c|}{ 3rd Quarter } & \multirow{2}{*}{ Ath } \\
\hline & & & & Jan & Feb & Mar & Apr & May & Jun & JuI & Aug & $\operatorname{sep}$ & Oct & Nov & Dec & $\operatorname{Jan}$ & Feb & Mar & Apr & May & Jun & Jul & Aug & Sep & \\
\hline 1 & Effective Well Dlameter & $4.5 \mathrm{M}$ & $0.00 \%$ & & & & & & & & & & & & & & & & & & & & & & \\
\hline 2 & Smear Effect & $9.5 \mathrm{~m}$ & $0.00 \%$ & & & & & & & & & & & & & & & & & & & & & & \\
\hline 3 & Well Resistance & $\mathbf{s m}$ & $0.00 \%$ & & & & & & & & & & & & & & & & & & & & & & \\
\hline 4 & PVD's Contaminant Transport Modet Verification & $7.5 \mathrm{M}$ & $0.00 \%$ & & & & & & & & & & & & & & & & & & & & & & \\
\hline 5 & Economic evaluation a Field Implementation Pia & 6M & $0.00 \%$ & & & & & & & & & & & & & & & & & & & & & & \\
\hline 6 & Reporting & $12 M$ & $25.00 \%$ & & & & & & & & & & & & & & & & & & & & & & \\
\hline 7 & Quarterly Report 1 & 0. & $100.00 x$ & & & & 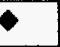 & & & & & & & & & & & & & & & & & & \\
\hline 8 & Quarterly Report 2 & ad & $0.00 \%$ & & & & & & & 0 & & & & & & & & & & & & & & & \\
\hline ? & Quarterly Report 3 & Od & $0.00 \%$ & & & & & & & & & $\diamond$ & & & & & & & & & & & & & \\
\hline 10 & Final Report & od & $0.00 \%$ & & & & & & & & & & & & 0 & & & & & & & & & & \\
\hline 11 & Overall Work Completed & $12 \mathrm{M}$ & $5.00 \%$ & & & & & & & & & & & & & & & & & & & & & & \\
\hline
\end{tabular}

Critical
Critical Milestone $\quad \diamond \begin{aligned} & \text { Noncritical } \\ & \text { Noncritical Milostone }\end{aligned}$

Completo

- Complete Milestone

P...... Delay
- Effort \%Complete

\section{Page \# 1}


METC TASK \#: 1.2: In-Situ Bioremediation of Chlorinated Organic Solvents

\section{MC- 2b Expenses In-Situ Bioremediation}

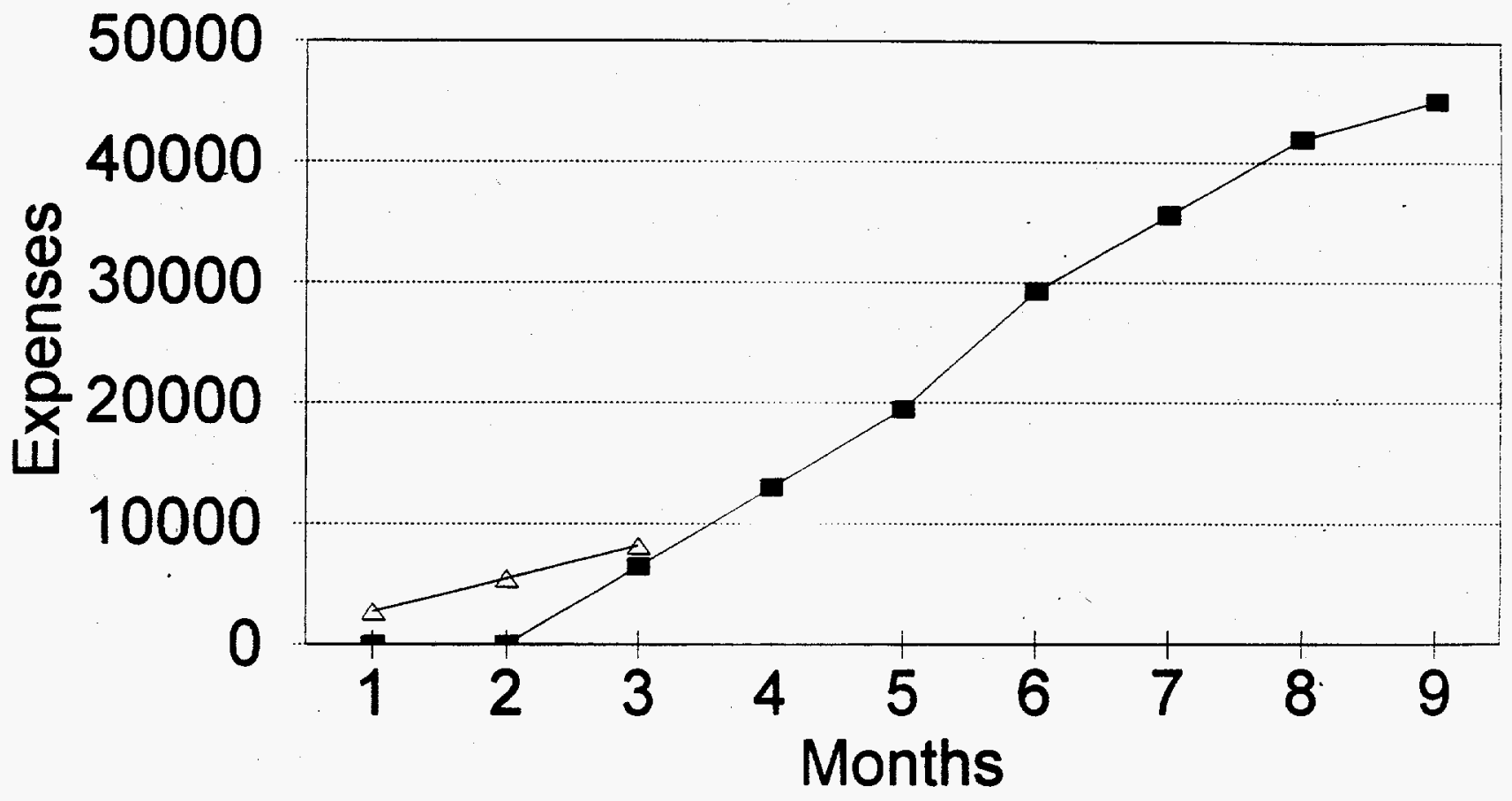

- Planned spending - Actual spending 


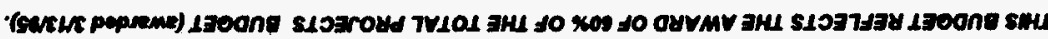

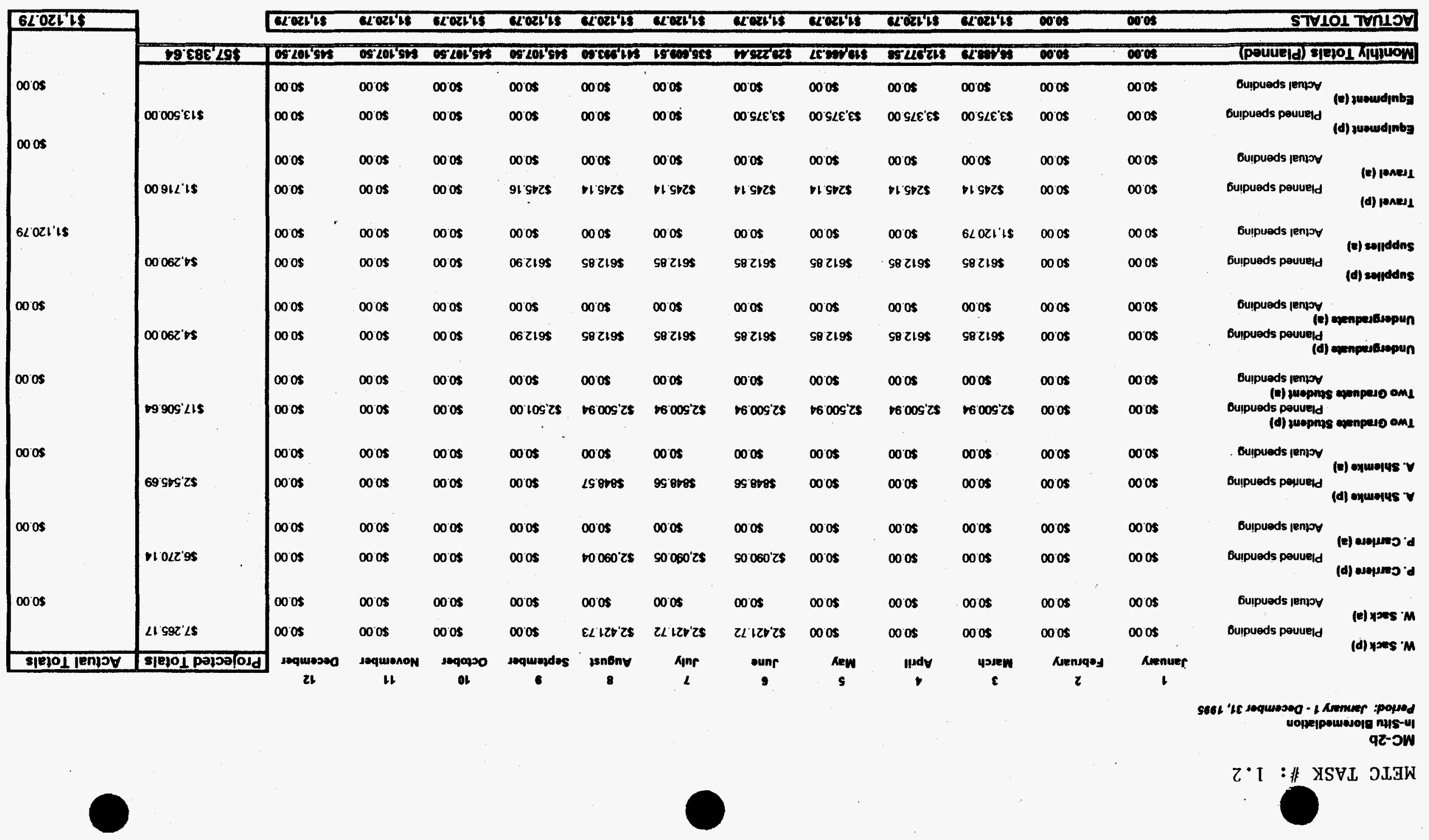


MC-2b

\begin{tabular}{|c|c|c|c|c|c|c|c|c|c|c|c|c|c|c|c|c|c|c|c|c|c|c|}
\hline \multirow{3}{*}{ Task Name } & \multirow{3}{*}{ Dura } & \multirow{3}{*}{ \%Compl } & \multicolumn{12}{|c|}{1995} & \multirow{2}{*}{\multicolumn{3}{|c|}{ Ist Quarter }} & \multicolumn{5}{|c|}{1996} \\
\hline & & & & tQuar & & & ¿Quar & & & Quar & & & Quart & & & & & & ¿Quan & & $3 \mathbf{r d}$ & \\
\hline & & & Jan & Feb & mar & Apr & May & Jun & Jul & Aug & Sep & oct & Nor & Dec & Jan & $\mathrm{Feb}$ & $\mathrm{Mar}$ & Apr & May & Jun & JuI & A \\
\hline Optimlzation of Sequential Mineralization & $11 \mathrm{M}$ & $30.00 \%$ & & & & & & & & & & & & & & & & & & & & \\
\hline Design \& Construction of Simultaneuos Min. Columns & 2m & $50.00 \%$ & & & & & & & & & & & & & & & & & & & & \\
\hline Dev. Testing of Protocol to Locate Zones & an & $100.00 \%$ & & & & & & & & & & & & & & & & & & & & \\
\hline Optimization of Simultancous Mineralization & $7 \mathrm{~m}$ & $0.00 \%$ & & & & & & & & & & & & & & & & & & & & \\
\hline Assessment of Potential Bioremediation of High Conc. of CAH Compoun & 4ne & $6.00 \%$ & & & & & & & & & & & & & & & & & & & & \\
\hline Design \& Const. of Lysimeters Equpped with PVD's & od & $0.00 \%$ & (....... & $\ldots$ & $\cdots \cdots$ & & & & & & & & & & & & & & & & & \\
\hline Amendments Delivery \& Potential Clogging & 8ny & $0.00 \%$ & & & & & & & & & & & & & & & & & & & & \\
\hline Reporting & $12 \mathrm{M}$ & $25.00 \%$ & & & & & & & & & & & & & & & & & & & & \\
\hline Quarterly Report 1 & od & $100.00 \%$ & & & & 7 & & & & & & & & & & & & & & & & \\
\hline Quarterly Report 2 & od & $0.00 \%$ & & & & & & & $\theta$ & & & & & & & & & & & & & \\
\hline Quarterly Report 3 & od & $0.00 \%$ & & & & & & & & & 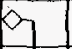 & & & & & & & & & & & \\
\hline Final Report & od & $0.00 \%$ & & & & & & & & & & & & & 0 & & & & & & & \\
\hline Overall Work Complete & $12 \mathrm{~m}$ & $26.25 \%$ & & & & & & & & & & & & & & & & & & & & \\
\hline
\end{tabular}

Critical

- Critical Milestone

Free Float

I...... Delay

$\diamond$ Noncritical
Noncritical Milostone
एZIZZ Total Float (+)

- Effort \%Complete

\section{Complete}

- Complete Milestone

EIIIT) Total Float (-)
Summary
- Summary Milestone
Baseline

201080 External

- External Milestono

..... Non-Resource

\section{Page \# 1}


METC TASK 非1.3: Microbial Enrichment for Enhancing In-Situ Biodegradation of Hazardous Organic Wastes

\section{MC-18 Expenses Microbial Enrichment}

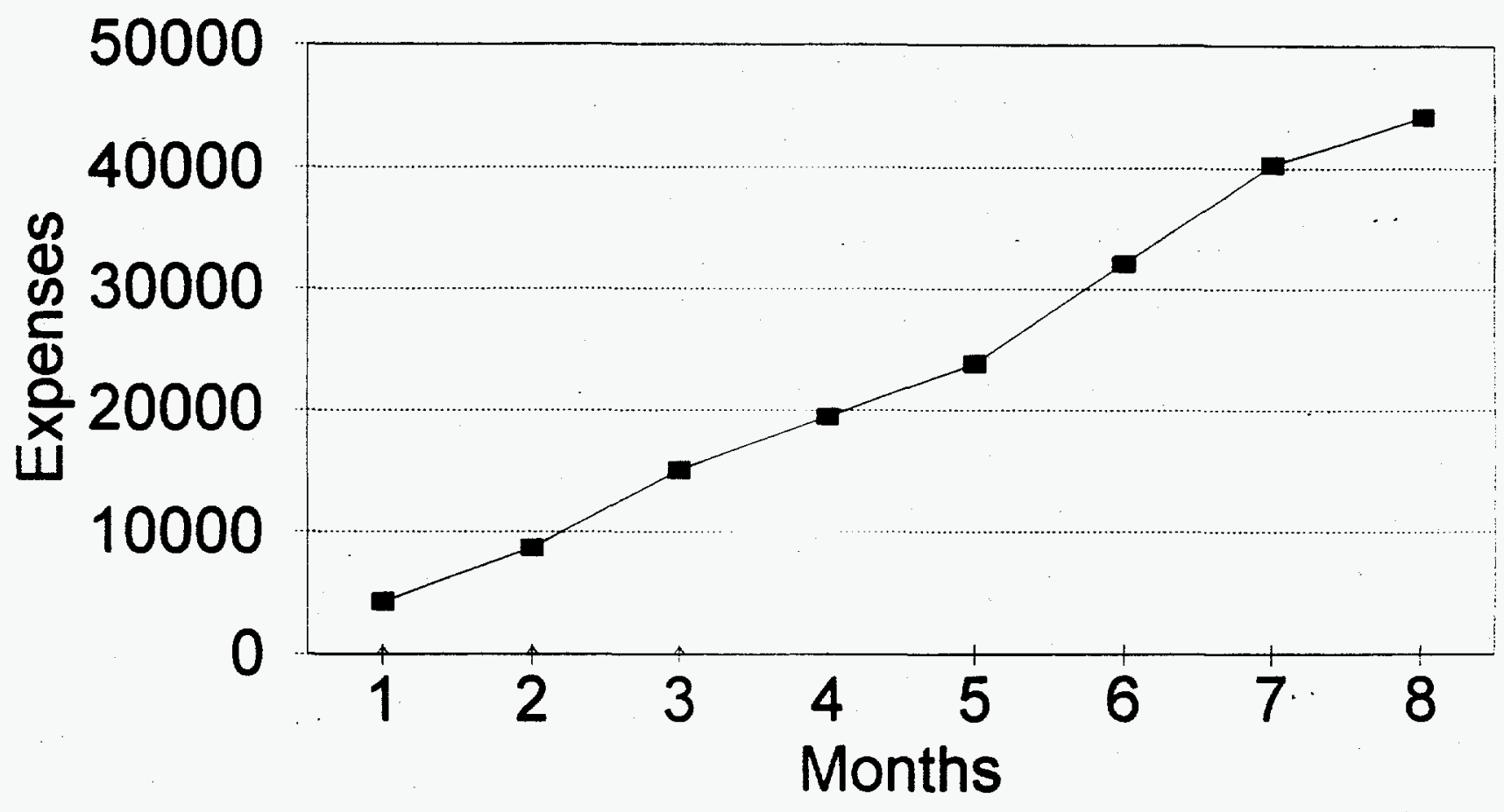

-- Planned spending - Actual spending 
METC TASK \#: 1.3

\section{MC-18}

Microbial Enrichment

Poriod: January 1-December 31, 1905

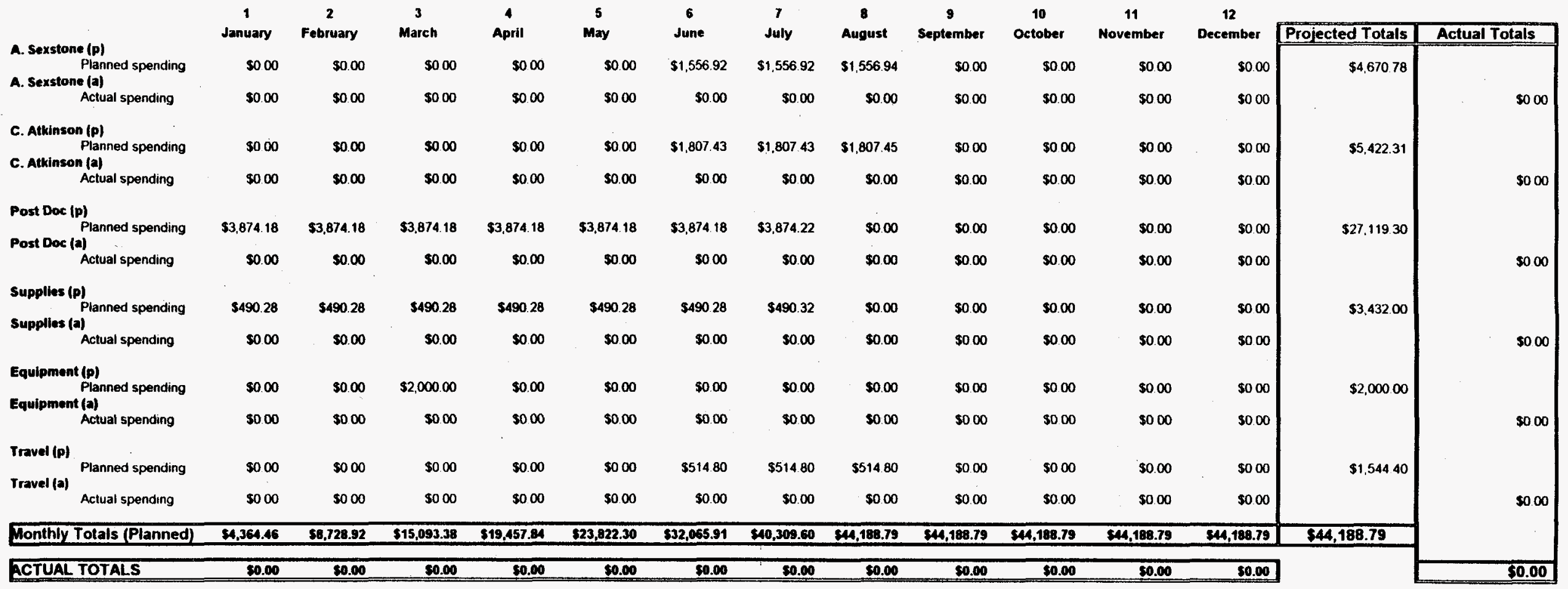

THW QUDOET REFLECTS THE AWARD OF CO\% OF THE TOTAL PRONECTS BUDCET (awarded MM395). 
METC TASK \#: 1.3

\section{MC-18}

\begin{tabular}{|c|c|c|c|c|c|c|c|c|c|c|c|c|c|c|c|c|c|c|c|c|c|c|c|c|c|c|c|}
\hline \multirow{3}{*}{$*$} & \multirow{3}{*}{ Task Name } & \multirow{3}{*}{ Dura } & \multirow{3}{*}{ xCompl } & \multirow{2}{*}{\multicolumn{12}{|c|}{\begin{tabular}{l}
\multicolumn{2}{c}{1985} \\
2nd Quarter
\end{tabular}}} & \multicolumn{12}{|c|}{1996} \\
\hline & & & & & & & & \multirow{2}{*}{\multicolumn{2}{|c|}{ 2nd Quarter }} & \multicolumn{2}{|c|}{ 3rd Quarter } & & \multicolumn{3}{|c|}{ 4th Quarter } & \multicolumn{3}{|c|}{ Ist Quarter } & \multicolumn{3}{|c|}{ 2nd Quarter } & \multicolumn{3}{|c|}{ 3rd Quarter } & \multicolumn{3}{|c|}{ 4th Quarter } \\
\hline & & & & Jan & Fob & Mar & Apr & & Jun & Jul & Aug & $\operatorname{sep}$ & Oet & Mov & Dec & Jen & Fob & Mar & Apr & May & Jun & JuI & Aug & Sep & Oct & Nov & $\overline{0}$ \\
\hline 1 & Prelliminary Research & $1.5 \mathrm{M}$ & $100.00 \%$ & & & & 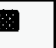 & & & & & & & & & & & & & & & & & & & & \\
\hline 2 & Analytical Techniques & $4 M$ & $0.00 \%$ & & & & & & & & & & & & & & & & & & & & & & & & \\
\hline 3 & Evaluate Radiorespirometry & $2 \mathrm{~m}$ & $0.00 \%$ & & & & & & & & & & & & & & & & & & & & & & & & \\
\hline 4 & Develop Radiorespirometric Assay & $2 \pi$ & $0.00 \%$ & & & & & & & & & & & & & & & & & & & & & & & & \\
\hline s & Preparation of Trials & $4 M$ & $0.00 \%$ & & & & & & & & & & & & & & & & & & & & & & & & \\
\hline 6 & Site Identification & $3 N$ & $0.00 \%$ & & & & & & & & & & & & & & & & & & & & & & & & \\
\hline 7 & Characterize soil & $3 n$ & $0.00 \%$ & & & & & & & & & & & & & & & & & & & & & & & & \\
\hline 8 & Waste Characterization & $3 \mathrm{n}$ & $0.00 \%$ & & & & & & & & & & & & & & & & & & & & & & & & \\
\hline \& & Finalize QNaC & $2 \mathrm{mi}$ & $0.00 \%$ & & & & & & & & & & & & & & & & & & & & & & & & \\
\hline 10 & Bioremedlation Trials & $5.5 \mathrm{M}$ & $0.00 \%$ & & & & & & & & & & & & & & & & & & & & & & & & \\
\hline 11 & Trial 1 & $6 w$ & $0.00 \%$ & & & & & & & 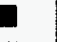 & & & & & & & & & & & & & & & & & \\
\hline 12 & Trial 2 & $6 m$ & $0.00 \%$ & & & & & & & & & & & & & & & & & & & & & & & & \\
\hline 13. & Trial 3 & $6 m$ & $0.00 \%$ & & & & & & & & & 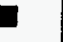 & & & & & & & & & & & & & & & \\
\hline 14 & Trial 4 & $6 m$ & $0.00 \%$ & & & & & & & & & & & & & & & & & & & & & & & & \\
\hline 16. & Trial 5 & $6 m$ & $0.00 \%$ & & & & & & & & & & & & & & & & & & & & & & & & \\
\hline 16 & Trial Reports (concurrent) & $5.5 \mathrm{M}$ & $0.00 \%$ & & & & & & & & & & & & & & & & & & & & & & & & \\
\hline 17 & Analysis a Reporting & 12M & $12.50 \%$ & & & & & & & & & & & & & & & & & & & & & & & & \\
\hline 21 & Analysis \& Data Reduction & $2 \mathrm{~m}$ & $0.00 \%$ & & & & & & & & & & & & & & & & & & & & & & & & \\
\hline 18 & Reports \& Manuscripts & $10 \mathrm{~m}$ & $26.00 \%$ & & & & & & & & & & & & & & & & & & & & & & & & \\
\hline & Overall Work Complete & 12M & $18.75 \%$ & & & & & & & & & & & & & & & & & & & & & & & & \\
\hline
\end{tabular}

20 Overall Work Complete

\begin{tabular}{|c|c|c|c|}
\hline 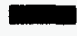 & Critical & . & Noncritical \\
\hline ○ & Critical Milestone & $\diamond$ & Noncritical Milestone \\
\hline 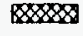 & Free Float & Eसात् & Total Float (t) \\
\hline P........ & Delay & $\Delta$ & Effort \%Completo \\
\hline
\end{tabular}

Complete
Complete Milestone
जIIIJ Total Float (-)

Summary
Summary Milestone
Baseline

External

1...... Delay

- Effort *Completo

Page \# 1 
METC TASK \#: 1.4: Contaminant Movement Prediction in Permeable Subsurface Soils

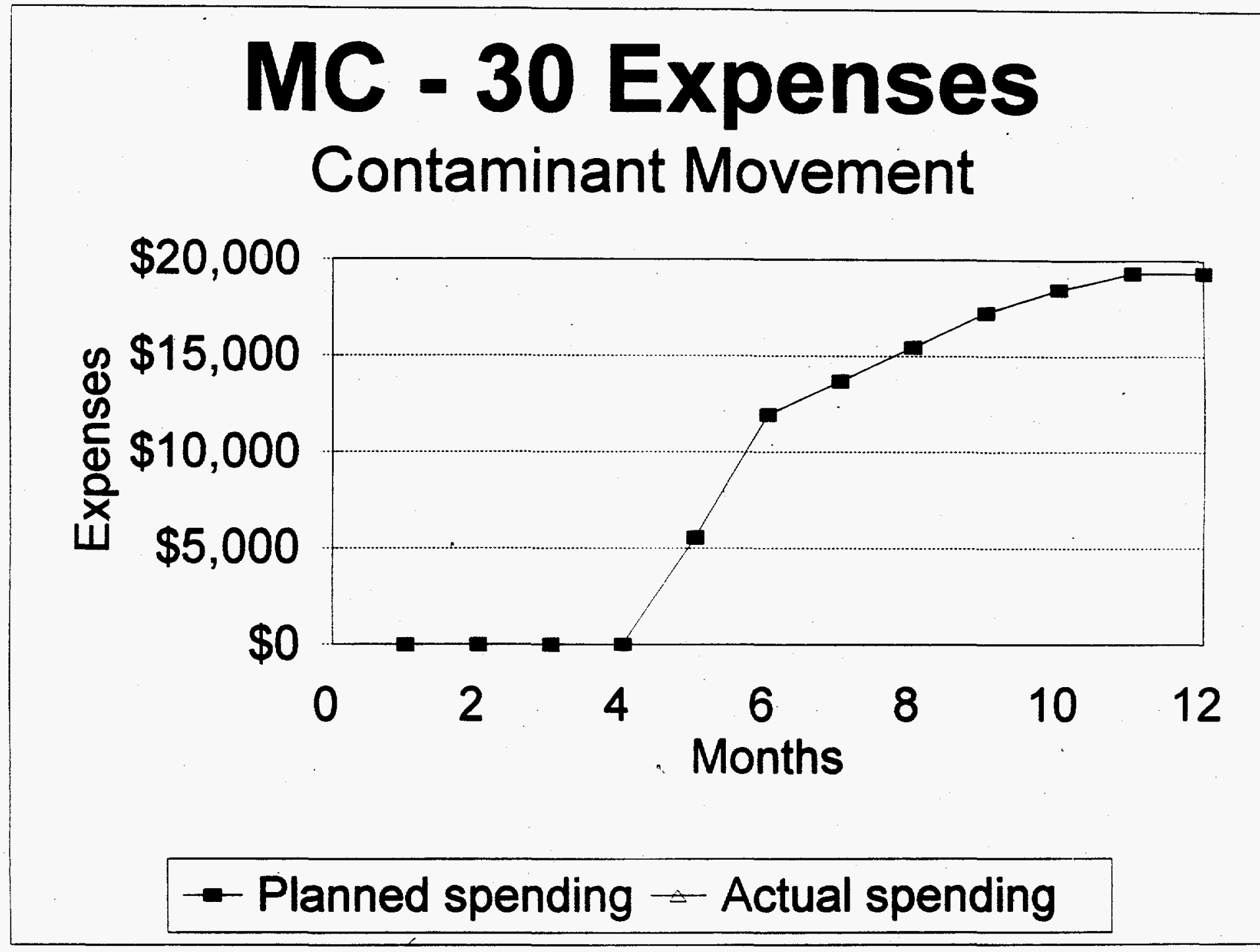


METC TASK \#: 1.4

\section{MC-30}

Contaminant Movement Prediction in Permeable Subsurface Solls Period: Jonuary 1 - Docember 31, 1995

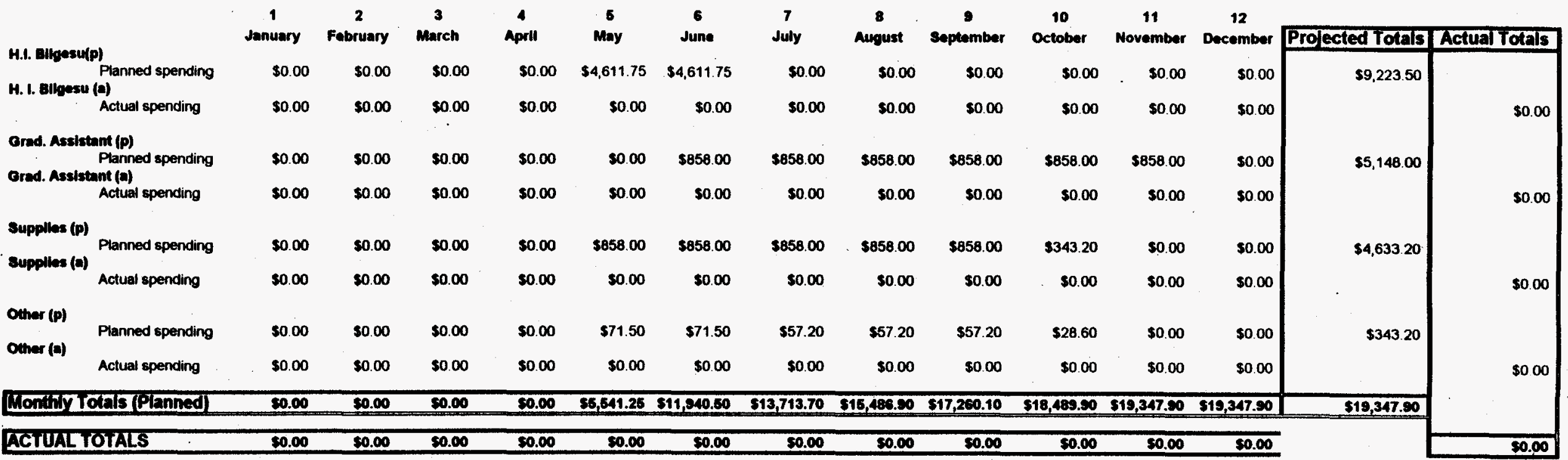

THS BUDGET REFLECTS THE AWAAO OF 60\% OF THE TOTAL PROJECTS BUDGET (awardod 3/13\%5). 
METC TASK \#: 1.4

\section{Contaminant Movement}

\begin{tabular}{|c|c|c|c|c|c|c|c|c|c|c|c|c|c|c|c|c|c|c|}
\hline \multirow{3}{*}{$*$} & \multirow{3}{*}{ Task Name } & \multirow{3}{*}{ Dura } & \multirow{3}{*}{ \%Compl } & \multirow[t]{2}{*}{1994} & \multicolumn{12}{|c|}{1995} & & \\
\hline & & & & & \multicolumn{3}{|c|}{ 1st Quarter } & \multicolumn{3}{|c|}{ 2nd Quarter } & \multicolumn{3}{|c|}{ 3rd Quarter } & \multicolumn{3}{|c|}{ 4th Quarter } & \multicolumn{2}{|c|}{ 1st Q } \\
\hline & & & & Dec & Jan & Feb & Mar & Apr & May & Jun & Jul & Aug & Sep & Oct & Nov & De & Jan & $F$ \\
\hline & Model Evaluation \& Ordering & $1 M$ & $0.00 \%$ & & & & & & & & & & & & & & & \\
\hline 2 & Software Acquisition \& Installation & $1 M$ & $0.00 \%$ & & & & & & & & & & & & & & & \\
\hline 3 & Model Calibration \& Data Preparation & $\mathbf{1 M}$ & $0.00 \%$ & & & & & & & & & & & & & & & \\
\hline 4 & Sensitivity Runs & $3 \mathrm{M}$ & $0.00 \%$ & & & & & & & & & & & & & & & \\
\hline & Final Report & $1 M$ & $0.00 \%$ & & & & & & & & & & & & & & & \\
\hline
\end{tabular}

\begin{tabular}{|c|c|c|c|c|}
\hline $\begin{array}{l}\text { Critical } \\
\diamond \quad \text { Critical Milestone } \\
8 \% \text { Free Float } \\
\text { 1...... Delay }\end{array}$ & $\begin{array}{l}\text { Noncritical } \\
\text { Noncritical Milestone } \\
\text { [IZZZZ Total Float (+) } \\
\text { Effort \%Complete }\end{array}$ & $\begin{array}{l}\text { Complete } \\
\text { Complete Milestone } \\
\text { Total Fioat (-) }\end{array}$ & $\begin{array}{l}\text { Summary } \\
\circ \quad \text { Summary Milestone } \\
\text { Baseline }\end{array}$ & $\begin{array}{l}\text { External } \\
\bullet \quad \text { External Milestone } \\
\cdots \cdots . . \text { Non-Resource }\end{array}$ \\
\hline
\end{tabular}


METC TASK \#: 1.5: Development of Standard Test Protocols \& Barrier Design Models

MC-26

B-11

NACCE STAFF

2 Comithmiez (P)

Ziromkiomicz (a) ${ }_{\text {Aclual spondinn }}$

c. Black (p)

c. Black (a) Planned spending

Socrotory (p)

secrotary (a) Planned sponding

E. Cook (p)

E. Cook (a) Planned spending Actual sponding

M. Gabr (p)

Gerer (a) Plenned spendiog Actual sponding

B. Reod (p)

C. Reod (a) Plasned spending

Gred. Accibtents (p)

Grad. Aeeverunte (1)
Actual spanding

Four Students (p)

Four studente (I)

Four Students (a)

S. Amori (p)

3. Amori (a) Planned spending Actusl spending

K. Aminion (p)

K. Aminian (a) Plamnod sponding

8. Mothaghoos (p)

5. Mothaguogen (D)

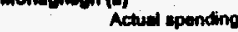

Toctrolecions (p)

Tectrnkieras (o) Planned spending

Supplibesother (p)

Supptibes Other (a) (a) spending

Actual sponding

Equipmone (p)

Equipmont (a) Planned spending Actual spending

BDM Subcontract (P)

BDM Subcontrnet (a)

Actual spending

Monthly Totals (Planned) CTUAL TOYALS

for In-Situ Formed Barriers

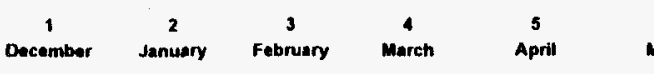

$\$ 0.00 \quad 5000 \quad 5000$

$\$ 0.00$

50.00

$6 \quad \begin{gathered}7 \\ \text { May }\end{gathered}$ .

$\$ 1,524.92 \quad \$ 1,524.92 \quad \$ 1,52492 \quad \$ 1,524.92$

$\begin{array}{llll}\$ 0.00 & \$ 1.160 .67 & \$ 1.180 .67 & \$ 1.160 .67\end{array}$

so.00. $\$ 1.249 .67 \quad \$ 1,249.67 \quad \$ 1,249.67$

$\$ 000 \quad 50.00 \quad 30.00 \quad \$ 0.00$

$\$ 0.00 \quad \$ 0.00 \quad \$ 0.00 \quad \$ 0.00$

$\$ 0.00 \quad \$ 0.00 \quad \$ 0.00 \quad \$ 0.00$

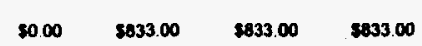

$\$ 0.00 \quad \$ 0.00 \quad \$ 000 \quad \$ 0.00$

$\begin{array}{llll}\$ 0.00 & \$ 815.00 & \$ 815.00 & \$ 815.00\end{array}$

$\$ 0.00 \quad \$ 0.00 \quad \$ 0.00 \quad \$ 0.00$

$\begin{array}{llll}\$ 0.00 & \$ 6.55+17 & \$ 6.551 .17 & \$ 6,551.17\end{array}$

$\begin{array}{lllll}50.00 & \$ 6,551.17 & \$ 6,551.17 & \$ 6,551.17\end{array}$

$\$ 50.00 \quad \$ 1,50000 \quad \$ 1,500.00 \quad \$ 1,500.00$

$\$ 000 \quad 5000 \quad 50.00 \quad \$ 0.00$

$\begin{array}{llll}\$ 0.00 & \$ 1,306.17 & \$ 1,306,17 & \$ 1,306.17\end{array}$

$\begin{array}{llll}50.00 & 50.00 & 50.00 & 50.00\end{array}$

$\$ 0.00 \quad \$ 1,341.67 \quad \$ 1,341.67 \quad \$ 1,341.67$

$\$ 0.00 \quad \$ 0.00 \quad \$ 0.00 \quad \$ 0.00$

$\begin{array}{llll}50.00 & \$ 933.17 & 5933.17 & 3933.17\end{array}$

$\$ 0.00 \quad \$ 0.00 \quad \$ 0.00 \quad \$ 0.00$

$\begin{array}{llll}5000 & 54,283.17 & 34,283.17 & \$ 4,283.17\end{array}$

$\begin{array}{lllll}\$ 0.00 & \$ 2,19967 & \$ 2,199.67 & \$ 2,199.67\end{array}$

$\$ 2.00 \quad \$ 2,484.83 \quad \$ 2,404.83 \quad \$ 2,484.83$

$\$ 000 \quad 50.00 \quad \$ 0.00 \quad \$ 0.00$

$\$ 0.00 \quad \$ 6,935.50 \quad \$ 6,935.50 \quad \$ 21,935.50$

$\begin{array}{llll}\$ 0.00 & \$ 0.00 \quad \$ 0.00 & \$ 15,000.00\end{array}$

$\$ 5000 \quad \$ 49,416.40 \quad \$ 49,41640 \quad \$ 49,416.40$

$\begin{array}{rrr}\$ 000 & \$ 0.00 & \$ 5.610 .66 \\ \$ 0.00 & \$ 0.00 & \$ 0.00\end{array}$

July August

September

Octobar

12

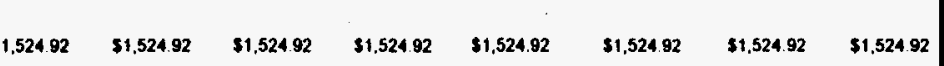

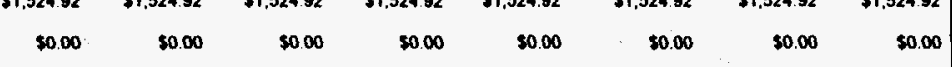

$\begin{array}{llllllll}\$ 1.249 .67 & \$ 1,249.67 & \$ 1,249.67 & \$ 0.00 & \$ 0.00 & \$ 000 & \$ 0.00 & \$ 0.00\end{array}$

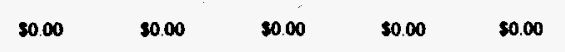

$\$ 0.00$

$\$ 0.00 \quad \$ 2,182.28 \quad \$ 2,182.28 \quad \$ 2,182.28$

$\$ 0.00$

$$
\$ 0.00
$$

$\begin{array}{rrrrr}\$ 833.00 & \$ 933.00 & \$ 833.00 & \$ 4.611 .75 & 4,611.75\end{array}$

$\begin{array}{llrrr}\$ 0.00 & \$ 0.00 & \$ 0.00 & 50.00 & \$ 1,459.50\end{array}$

$\begin{array}{lllll}\$ 815.00 & \$ 815.00 & \$ 815.00 & \$ 4,508.45 & \text { M, 508.45 }\end{array}$

$\begin{array}{lllll}\$ 0.00 & \$ 0.00 & \$ 0.00 & \$ 0.00 & \$ 1.459 .50\end{array}$

$\begin{array}{lllll}\$ 6,551.17 & \$ 6,551.17 & \$ 6.551 .17 & \$ 0.00 & \$ 000\end{array}$

$\begin{array}{lllll}\$ 0.00 & 50.00 & 5000 & 50.00 & \$ 0.00\end{array}$

$\$ 1,50000 \quad \$ 1,50000 \quad \$ 1,500,00 \quad \$ 000 \quad \$ 100$

$\begin{array}{lllll}\$ 0.00 & 50.00 & 50.00 & 50.00 & 5000\end{array}$

$\$ 1,306,17 \quad \$ 1,30617 \quad \$ 1,306.17$

$\$ 0.00 \quad 50.00 \quad \$ 000 \quad \$ 000$

$\begin{array}{llll}\$ 1,341.67 & \$ 1.341 .67 \quad \$ 1,341.67 \quad \$ 0.00\end{array}$

$\$ 000 \quad \$ 0.00 \quad \$ 0.00 \quad \$ 0.00$

$\begin{array}{llll}5933.17 & 5933.17 \quad 5033.17 \quad 30.00\end{array}$

$\$ 0.00 \quad 50.00 \quad 5000 \quad 5000 \quad 30,00$

$\begin{array}{lllll}\$ 4.283 .17 & \$ 4.263 .17 & \$ 4.283 .17 & \$ 0.00 & \$ 0.00\end{array}$

$\begin{array}{lllll}\$ 0.00 & \$ 0.00 & \$ 0.00 & \$ 0.00 & \$ 0.00\end{array}$

$52.48483 \quad 52.484 .83 \quad 52,40480$

$\$ 6,935.50 \quad \$ 6,935.50$

$\$ 0.00 \quad \$ 0.00 \quad \$ 0.00$

$50.00 \quad 50.00$

$\$ 0.00 \quad \$ 10,000.00 \quad \$ 10,000.00$

$\$ 2,182,28 \quad \$ 2,182.28 \quad \$ 2,182.28$

$5000 \quad 50.00$

5

20.00

$\$ 0.00$

80.00

5000

50.00

5000

$\$ 0.00$

$\$ 0.00$

50.00

$\$ 0.00$

$\$ 5000$

5000

$\$ 0.00$

$\$ 0.00$

50.00

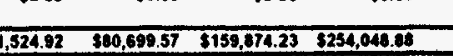

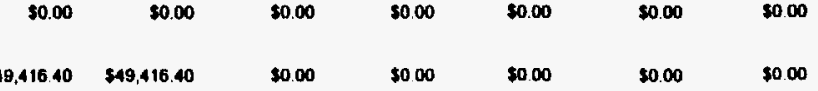

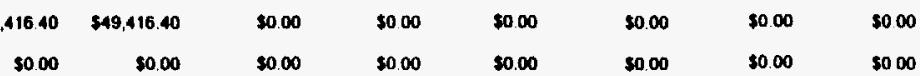

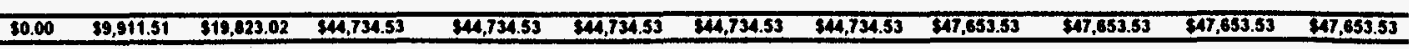

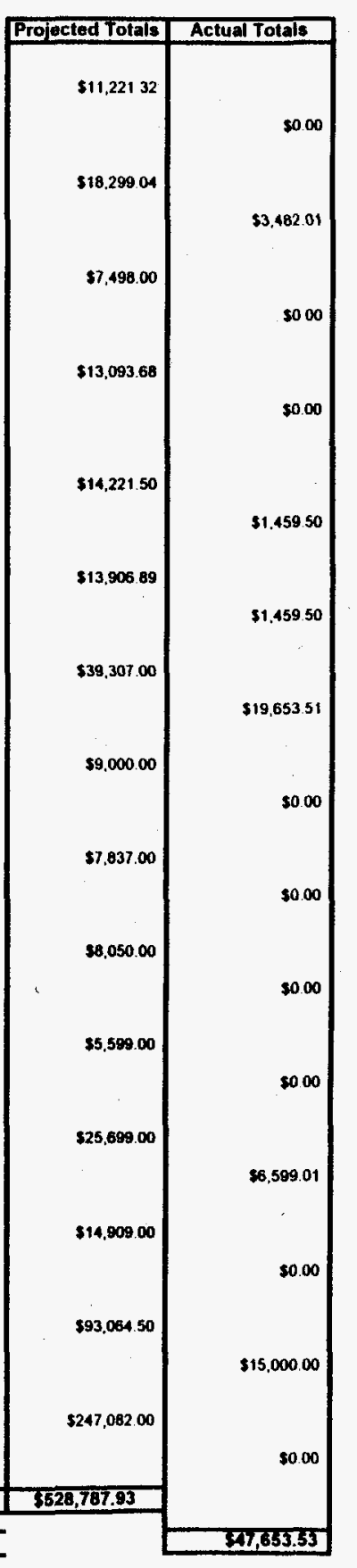




\section{Pro,tet: MC26 B-17 Barrier Project -- METC TAS, $1: 1.5$}

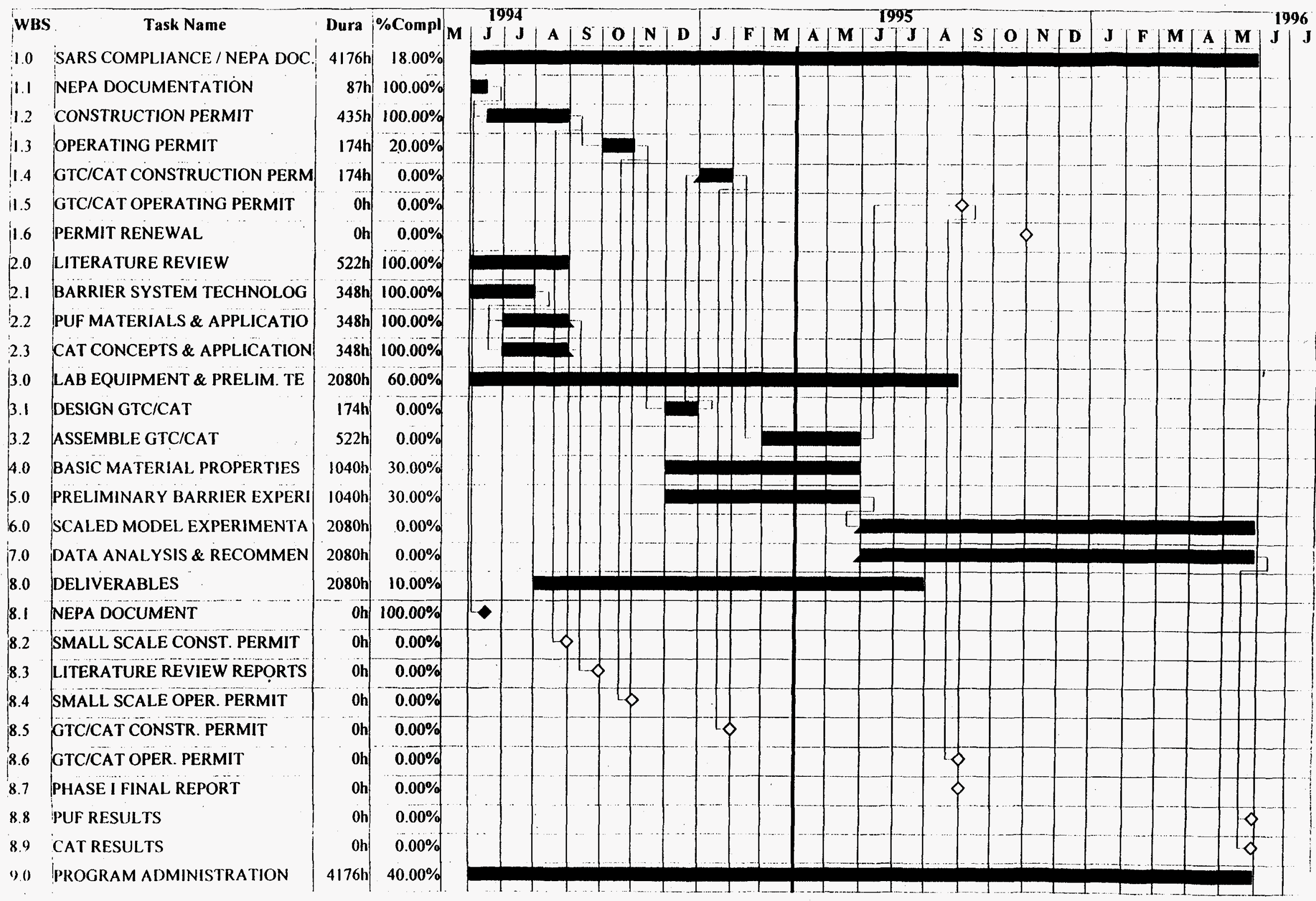




\section{0 \\ ADVANCED PRODUCT \\ APPLICATIONS TESTING}


$-44-$ 
METC TASK \#: 2.1: Chemical Destruction of Chlorinated Organic Compounds

\section{MC-6 Expenses \\ Chemical Destruction}

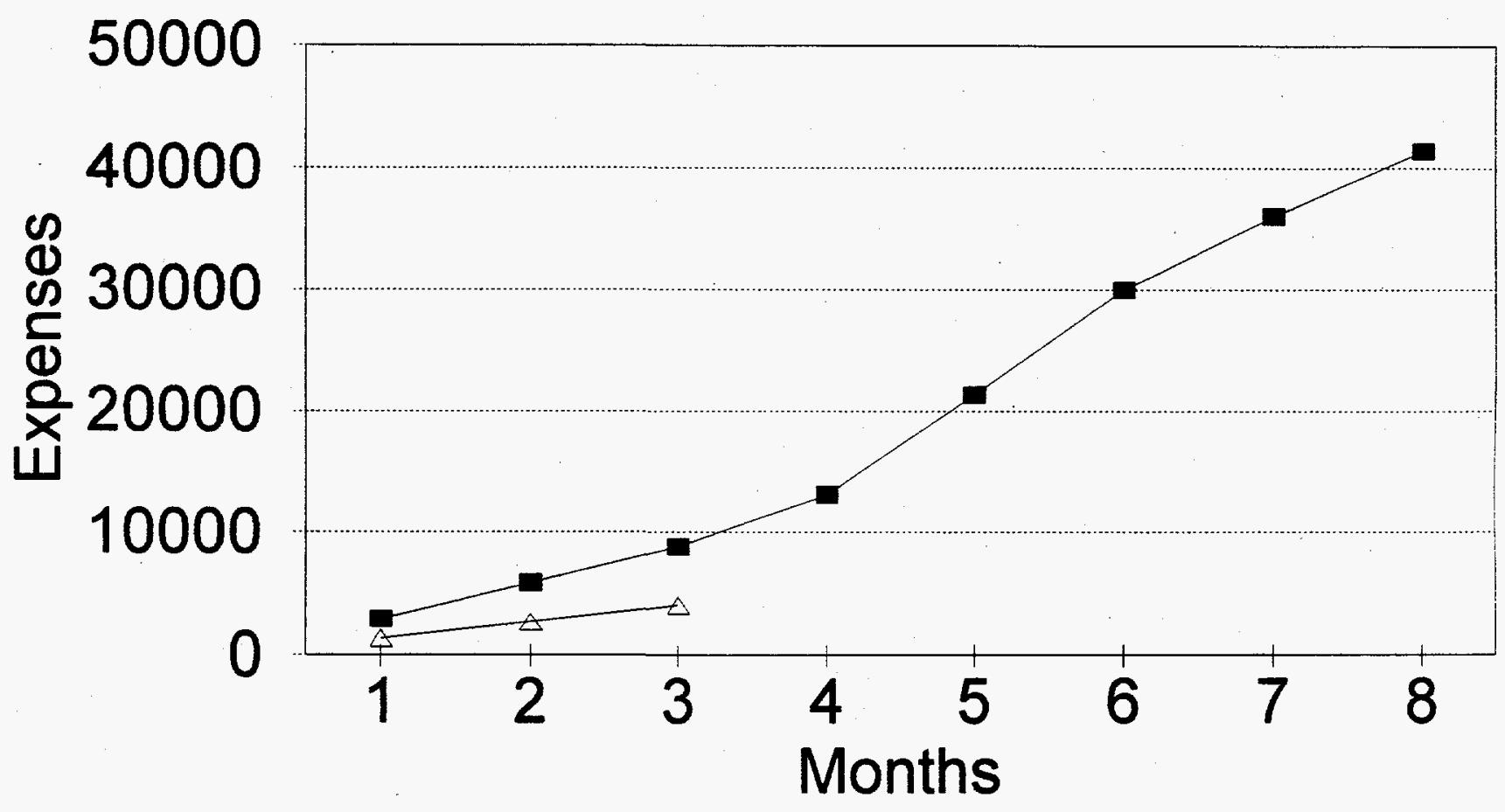

- Planned spending $\triangle$ Actual spending 


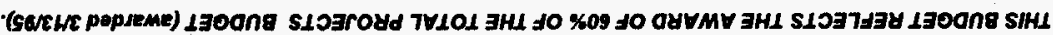

\begin{tabular}{|c|c|c|c|c|c|c|c|c|c|c|c|c|c|c|}
\hline OS'9LO'DS & & 09'9lo's & OS $910^{\circ} t s$ & OS'9LO'ts & $0 \sec ^{\prime} \angle 0^{\prime} t s$ & os'sLo'ns & OS'SLO'ts & $05^{\prime} 9 \angle 0^{\prime} n s$ & $09^{\circ} S \angle 0^{\prime}+{ }^{\prime}$ & OS'SLO'rs & osslo't & DOLLL'ZS & OS: $8 \varepsilon^{2}$ WS & 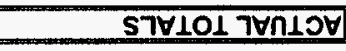 \\
\hline & 9lLtoths & 9riterites & 9lithith & gitorites & 9ling'Ls & 9itorith & Egiso'ses & BZ $296^{6} 6 Z 5$ & S60E' & $99^{\circ} \mathrm{EZT}$ हाS & $28^{8} z^{\prime} 8^{\prime} 85$ & $89^{\prime} 288^{\prime} \mathrm{SS}$ & 6216625 & 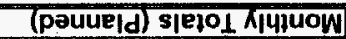 \\
\hline $000 s$ & $00898 \$$ & $\begin{array}{l}000 \mathrm{0s} \\
000 \mathrm{0}\end{array}$ & $\begin{array}{l}000 \$ \\
0008\end{array}$ & $\begin{array}{l}000 \$ \\
000 \$\end{array}$ & $\begin{array}{l}000 \$ \\
0005\end{array}$ & $\begin{array}{l}000 \$ \\
000 \$\end{array}$ & $\begin{array}{l}0005 \\
006 z+5\end{array}$ & $\begin{array}{l}000 \$ \\
006 z+\$\end{array}$ & $\begin{array}{l}000 \$ \\
000 \$\end{array}$ & $\begin{array}{l}000 \$ \\
000 \$\end{array}$ & $\begin{array}{l}000 \$ \\
000 \$\end{array}$ & $\begin{array}{l}\infty 00 s \\
000 s\end{array}$ & $\begin{array}{l}000 \$ \\
0008\end{array}$ & $\begin{array}{l}\text { Gu!puəds jenłə } \\
\text { Gu!puəds pəuueld }\end{array}$ \\
\hline $00.0 \mathrm{~s}$ & $9 \varepsilon Z 99^{\prime} \mathrm{Zl \$}$ & $\begin{array}{l}000 \$ \\
000 s\end{array}$ & $\begin{array}{l}000 \$ \\
000 s\end{array}$ & $\begin{array}{l}000 \$ \\
0005\end{array}$ & $\begin{array}{l}000 \$ \\
0008\end{array}$ & $\begin{array}{l}000 \mathrm{~s} \\
\varepsilon 8 \mathrm{ZBS}^{\prime} \text { is }\end{array}$ & $\begin{array}{l}000 \$ \\
6 \angle Z 8 S^{\prime} 18\end{array}$ & $\begin{array}{l}000 \$ \\
6 \angle 28 S^{\prime} 15\end{array}$ & $\begin{array}{l}000 \$ \\
6 \angle Z 8 S^{\prime} 1 S\end{array}$ & $\begin{array}{l}0005 \\
6 L^{\prime 28 S^{\prime}} \mid \$\end{array}$ & $\begin{array}{l}000 \$ \\
6 \angle Z 8 S^{\prime} I \$\end{array}$ & $\begin{array}{l}000 S \\
6 \angle 28 S^{\prime} 1 \$\end{array}$ & $\begin{array}{l}0008 \\
6 L^{\prime} Z 8 S^{\prime} 1 \$\end{array}$ & 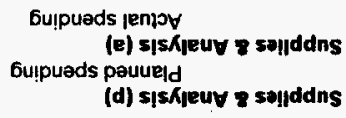 \\
\hline 0005 & sてeı'9\$ & $\begin{array}{l}000 \$ \\
000 \$\end{array}$ & $\begin{array}{l}000 \$ \\
000 \$\end{array}$ & $\begin{array}{l}000 \$ \\
0005\end{array}$ & $\begin{array}{l}000 \$ \\
0005\end{array}$ & $\begin{array}{l}000 \$ \\
0989 \varepsilon^{\prime} \text { 's }\end{array}$ & $\begin{array}{l}000 \$ \\
0989 \varepsilon^{\prime} 1 \$\end{array}$ & $\begin{array}{l}\infty 00 \$ \\
0 s 85 \varepsilon^{\prime} \text { is }\end{array}$ & $\begin{array}{l}\text { oo } 0 \$ \\
\text { os } 89 \varepsilon^{\prime} \text { is }\end{array}$ & $\begin{array}{l}000 \$ \\
9 Z 6 \angle 9 \$\end{array}$ & $\begin{array}{l}0008 \\
0008\end{array}$ & $\begin{array}{l}000 \mathrm{OS} \\
000 \mathrm{OS}\end{array}$ & $\begin{array}{l}000 \$ \\
000 \$\end{array}$ & 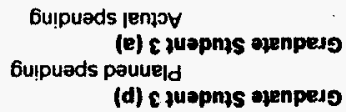 \\
\hline 000 s & stell'ss & $\begin{array}{l}0005 \\
0005\end{array}$ & $\begin{array}{l}000 \$ \\
000 \$\end{array}$ & $\begin{array}{l}0005 \\
0005\end{array}$ & $\begin{array}{l}\text { 000s } \\
000 \text { s }\end{array}$ & $\begin{array}{l}\text { OOOS } \\
\text { OG. BSE'IS }\end{array}$ & $\begin{array}{l}\text { 00.0s } \\
\text { OS.8SE' is }\end{array}$ & $\begin{array}{l}\text { oo } 0 \$ \\
\text { os } 85 \varepsilon^{\prime} \text { is }\end{array}$ & $\begin{array}{l}\text { oo'os } \\
\text { os } 89 \varepsilon^{\prime} \text { is }\end{array}$ & $\begin{array}{l}000 \$ \\
9 Z 6 \angle 9 \$\end{array}$ & $\begin{array}{l}000 \$ \\
000 \$\end{array}$ & $\begin{array}{l}000 \mathrm{os} \\
000 \mathrm{OS}\end{array}$ & $\begin{array}{l}0008 \\
000 \$\end{array}$ & 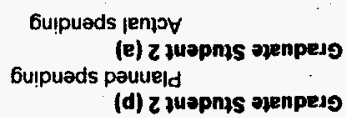 \\
\hline OS S $\angle O^{\prime} \square S$ & OE'96s'ols & $\begin{array}{l}000 s \\
000 s\end{array}$ & $\begin{array}{l}000 s \\
000 s\end{array}$ & $\begin{array}{l}000 s \\
0005\end{array}$ & $\begin{array}{l}000 \$ \\
000 \$\end{array}$ & $\begin{array}{l}000 \$ \\
08.980^{\prime}+\$\end{array}$ & $\begin{array}{l}000 \$ \\
0 \varsigma 8 s \varepsilon^{\prime} \mid \$\end{array}$ & $\begin{array}{l}000 \$ \\
\text { OS } 8 \text { SE' IS }^{\circ}\end{array}$ & $\begin{array}{l}\text { ODOS } \\
\text { OS } 85 E^{\prime} 1 \$\end{array}$ & $\begin{array}{l}000 \$ \\
0 S^{\prime} 8 \varepsilon^{\prime} 1 \$\end{array}$ & $\begin{array}{l}\text { OS 8SE' is } \\
\text { OS \&SE' is }\end{array}$ & $\begin{array}{l}\text { OS BSE'IS } \\
\text { OS'8SE'IS }\end{array}$ & $\begin{array}{l}\text { OS } 8 S E^{\prime} 1 \$ \\
\text { OS'8SE' I\$ }\end{array}$ & 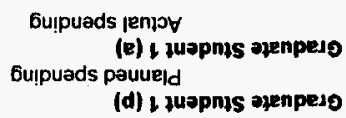 \\
\hline $000 \$$ & 00.860 's\$ & $\begin{array}{l}000 s \\
000 \$\end{array}$ & $\begin{array}{l}0008 \\
0008\end{array}$ & $\begin{array}{l}\infty 00 \$ \\
\infty 00 \$\end{array}$ & $\begin{array}{l}000 \$ \\
000 \$\end{array}$ & $\begin{array}{l}000 \$ \\
000 s\end{array}$ & $\begin{array}{l}000 \$ \\
000 \$\end{array}$ & $\begin{array}{l}000 \$ \\
006 \mathrm{bs} z \$\end{array}$ & $\begin{array}{l}000 \$ \\
0060 \mathrm{~s} z s\end{array}$ & $\begin{array}{l}000 \$ \\
000 \$\end{array}$ & $\begin{array}{l}0008 \\
000 s\end{array}$ & $\begin{array}{l}000 s \\
000 s\end{array}$ & $\begin{array}{l}000 \$ \\
000 \$\end{array}$ & $\begin{array}{l}\text { Gu!puads jenjo } \\
\text { Gu!puads pauueld }\end{array}$ \\
\hline s|ejol |enjoy & 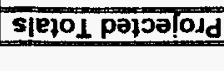 & $\begin{array}{c}\text { Jequeэra } \\
\text { Zl }\end{array}$ & $\begin{array}{c}\text { Joquirnon } \\
\text { HL }\end{array}$ & $\begin{array}{c}1290190 \\
\text { of }\end{array}$ & $\begin{array}{c}\text { Jequezdas } \\
6\end{array}$ & $\begin{array}{c}2 \sin \sin \gamma \\
8\end{array}$ & $\begin{array}{c}\text { Kinr } \\
L\end{array}$ & $\begin{array}{c}\text { sunr } \\
9\end{array}$ & $\begin{array}{c}\text { NEW } \\
S\end{array}$ & upd & $\begin{array}{c}\text { YJuew } \\
\varepsilon\end{array}$ & $\begin{array}{c}\text { Kueniqa } \\
\tau\end{array}$ & $\begin{array}{c}\text { Kuenuer } \\
\downarrow\end{array}$ & \\
\hline
\end{tabular}

S66L 'iE saquasog - \& Menuer :poped

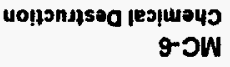

$\tau \cdot 乙$ : \#非SH OLJW 
METC TASK \# : 2.1

\section{MC-6}

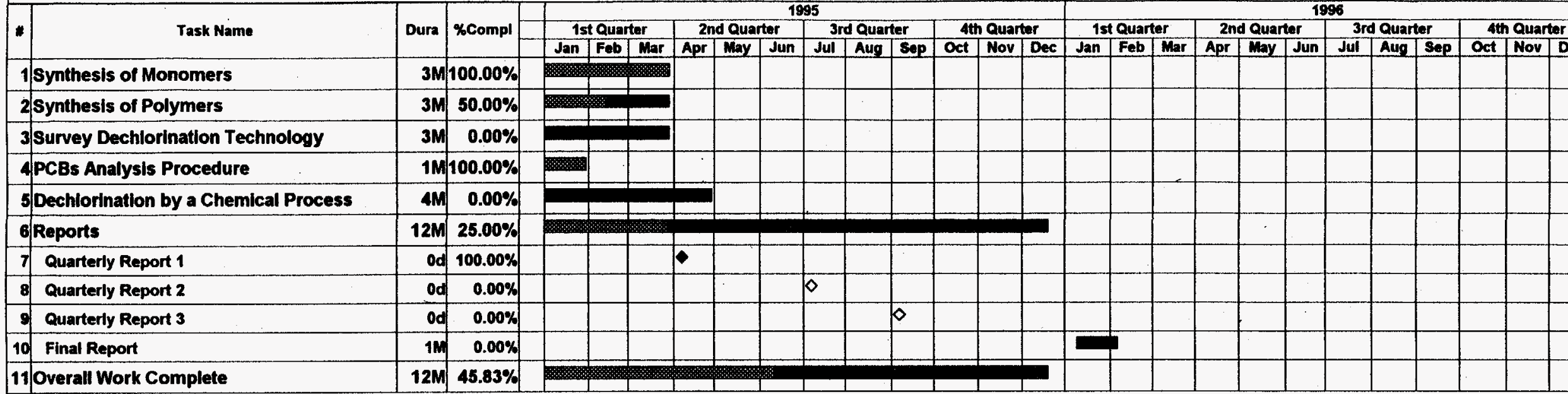

11 Overall Work Complete

\begin{tabular}{|c|c|c|c|}
\hline 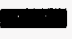 & Critical & & Noneritical \\
\hline$\odot$ & Critical Milestone & $\diamond$ & Noncritical Milestone \\
\hline $5 x+x$ & Free Float & EZZZ & Total Float (+) \\
\hline t...... & Delay & - & Effort \%Complete \\
\hline
\end{tabular}
Complete
- Complete Milestone
WIIST Total Float (-)
Summary
- Summary Milostone

External

I...... Delay

- Effort \%Complete

\section{Page \# 1}


METC TASK \#: 2.2: Continued Development of an Atmospheric Monitoring Mass Spectrometry System

\section{MC-23 Expenses IR and Mass Spec.}

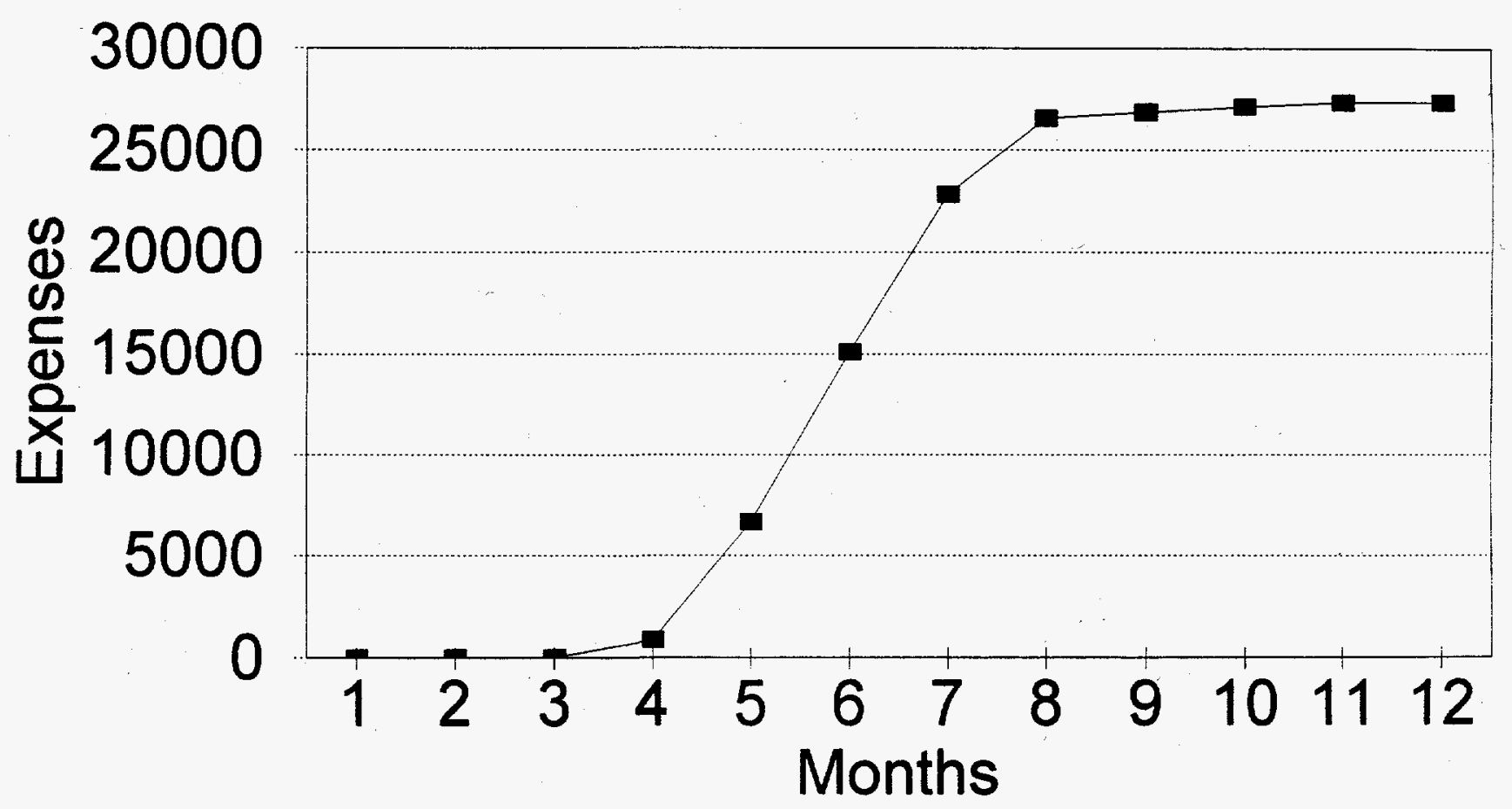

- Planned spending $\triangle$ Actual spending 


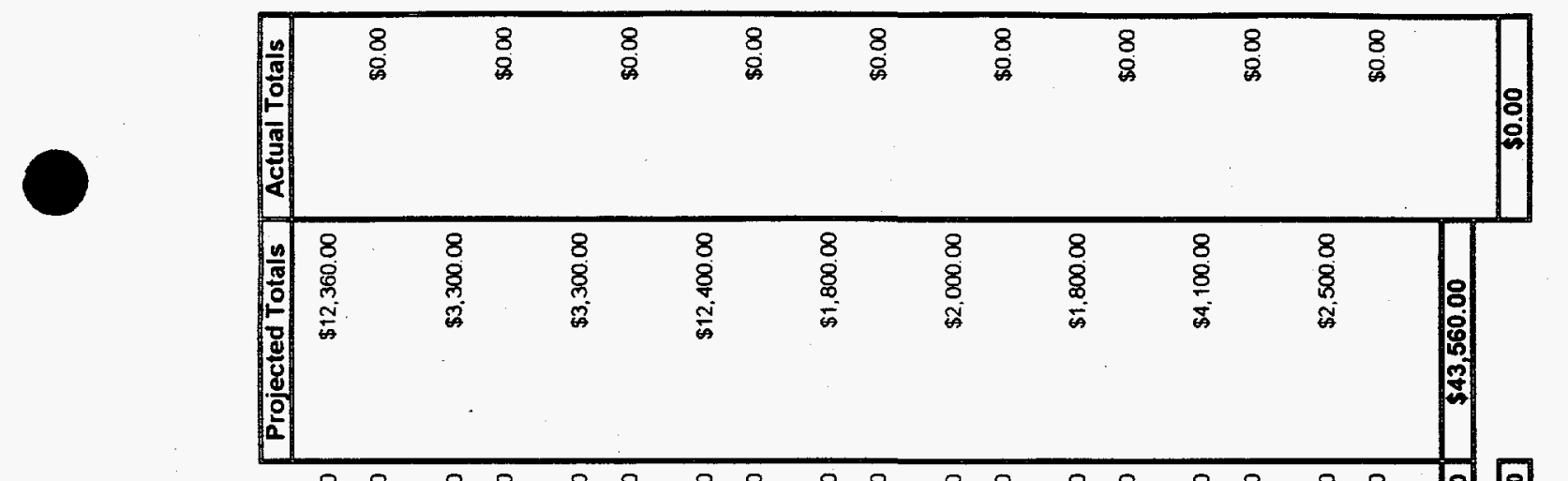

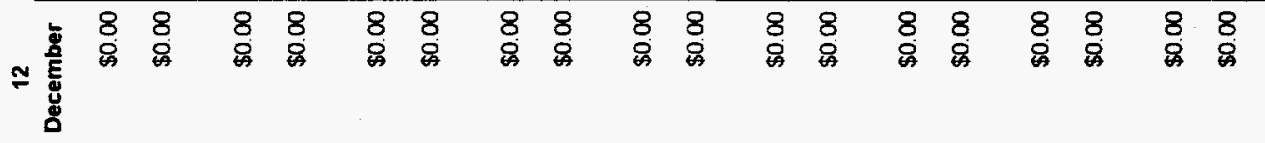

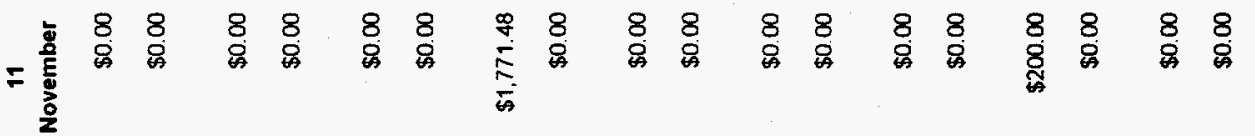

유용

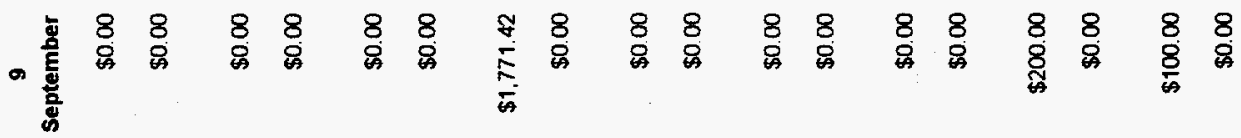

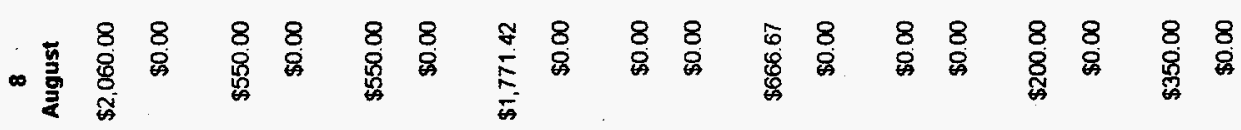

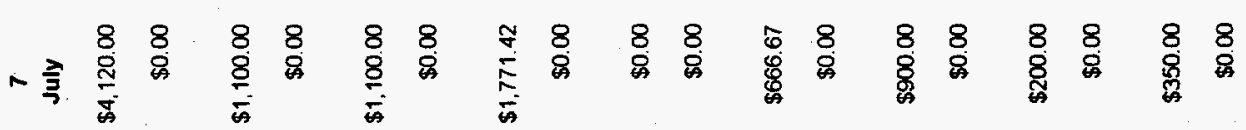

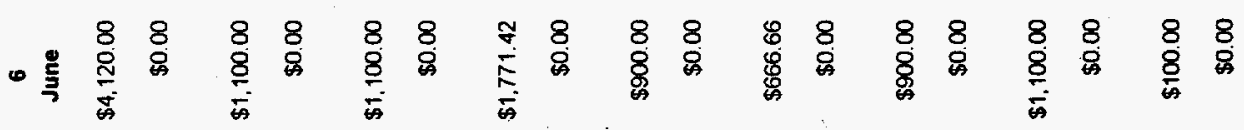

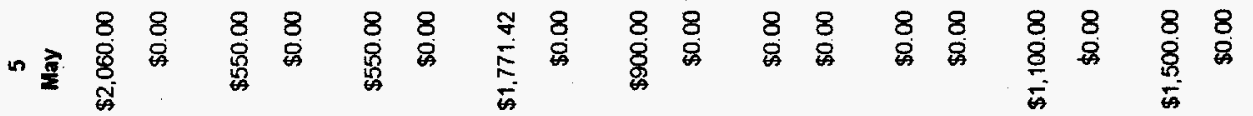

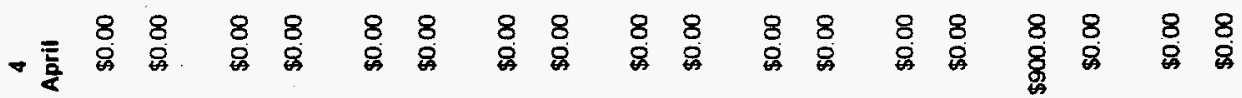

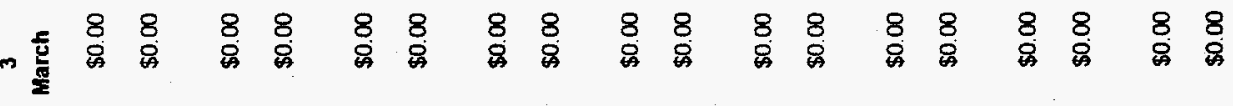

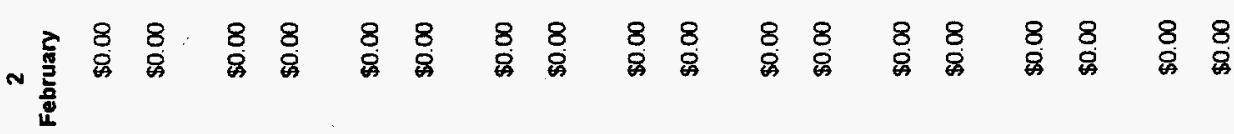

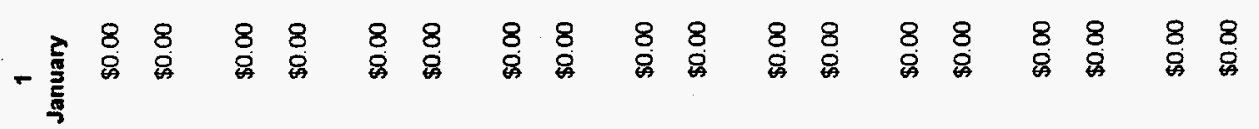

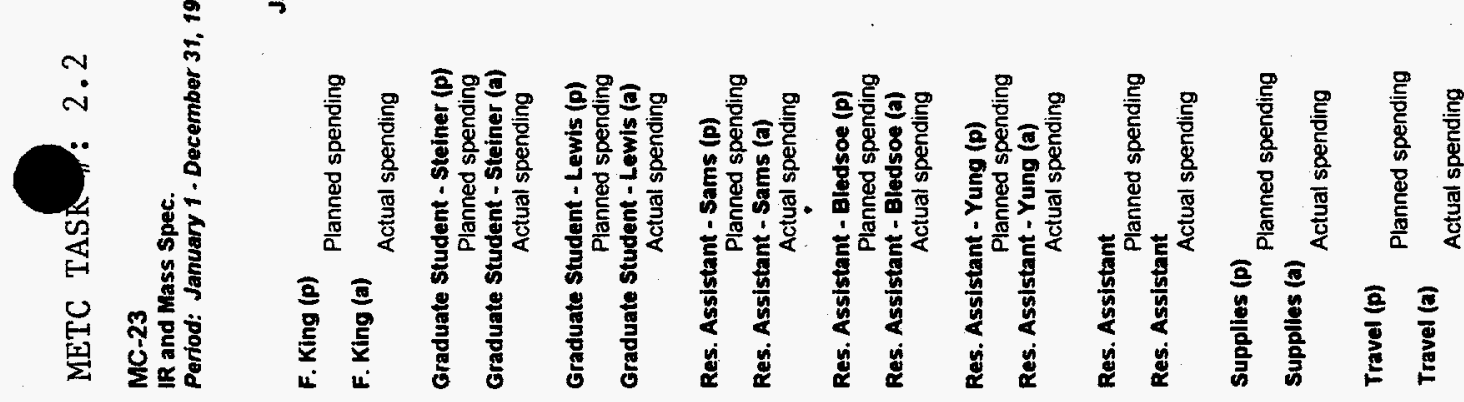




\section{MC-23}

\begin{tabular}{|c|c|c|c|c|c|c|c|c|c|c|c|c|c|c|c|c|c|c|c|c|c|c|c|c|c|c|c|}
\hline \multirow{3}{*}{ 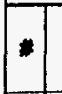 } & \multirow{3}{*}{ Task Name } & \multirow{3}{*}{ Dura } & \multirow{3}{*}{ \%Compl } & \multicolumn{12}{|c|}{1995} & \multicolumn{12}{|c|}{1996} \\
\hline & & & & \multicolumn{3}{|c|}{ 1st Quarter } & \multicolumn{3}{|c|}{ 2nd Quarter } & \multicolumn{3}{|c|}{ 3rd Quarter } & \multicolumn{3}{|c|}{ 4th Quarter } & \multicolumn{3}{|c|}{ Ist Quarter } & \multicolumn{3}{|c|}{ 2nd Quarter } & \multicolumn{3}{|c|}{ 3rd Quarter } & \multicolumn{3}{|c|}{ 4th Quarter } \\
\hline & & & & $\operatorname{Jan}$ & Feb & Mar & Apr & May & Jun & Jul & Aug & Sep & Oet & Nov & Dec & Jan & Fob & Mar & Apr & May & Jun & Jul & Aug & Sep & Oct & & $D$ \\
\hline 1 & Purchase Standards & $1 M$ & $0.00 \%$ & & & & & & & & & & & & & & & & & & & & & & & & \\
\hline & Hydrocarbon Determination & 5M & $0.00 \%$ & & & & & & & & & & & & & & & & & & & & & & & & \\
\hline 3 & Ethylbenzene/xylenes & $2 \mathrm{M}$ & $0.00 \%$ & & & & $\square$ & & & & & & & & & & & & & & & & & & & & \\
\hline 4 & Ionization Optimization & $3 \mathrm{M}$ & $0.00 \%$ & & & & & & & & & & & & & & & & & & & & & & & & \\
\hline 8 & Environmental Interferences & $2 \mathrm{~m}$ & $0.00 \%$ & & & & & & & & & & & & & & & & & & & & & & & & \\
\hline 6 & Winfield Demonstration & $1 \mathrm{~m}$ & $0.00 \%$ & & & & & & & & & & & & & & & & & & & & & & & & \\
\hline & Halogenated Hydrocarbon Determination & $6 M$ & $0.00 \%$ & & & & & & & & & & & & & & & & & & & & & & & & \\
\hline 8 & Ionization Optimization & $3 M$ & $0.00 \%$ & & & & & . & & & 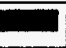 & & & & & & & & & & & & & & & & \\
\hline 9 & Interference Evaluation & $3 m$ & $0.00 \%$ & & & & & & & & & 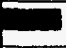 & & & & & & & & & & & & & & & \\
\hline 10 & Interference Amelioration & $4 M$ & $0.00 \%$ & & & & & & & & & & & & & & & & & & & & & & & & \\
\hline 11 & Report Writing & $12 M$ & $25.00 \%$ & & & & & & & & & & & & & & & & & & & & & & & & \\
\hline 12 & Quarterly Report 1 & od & $100.00 \%$ & & & & $\bullet$ & & & & & & & & & & & & & & & & & & & & \\
\hline 13 & Quarterly Report 2 & Od & $0.00 \%$ & & & & & & & 0 & & & & & & & & & & & & & & & & & \\
\hline & Quarterly Report 3 & od & $0.00 \%$ & & & & & & & & & 8 & & & & & & & & & & & & & & & \\
\hline & Final Report & $\mathbf{O d}$ & $0.00 \%$ & & & & & & & & & & & & & $\diamond$ & & & & & & & & & & & \\
\hline & Overall Work Complete & $12 M$ & $6.25 \%$ & & & & & & & & & & & & & & & & & & & & & & & & \\
\hline
\end{tabular}

\begin{tabular}{|c|c|c|c|}
\hline & Critical & & Noncritical \\
\hline 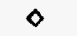 & Critical Milestone & 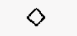 & Noncritical Milestone \\
\hline 208 & Free Float & एस]त्य & Total Float $(+)$ \\
\hline t....... & Delay & - & Effort \%Complete \\
\hline
\end{tabular}

\section{Page \# 1}


METC TASK \#: 2.3: Capture of Hazardous Chemical Waste Materials Utilizing Fluidization Coating Technology

\section{MC - 29 Expenses \\ Coating Technology}

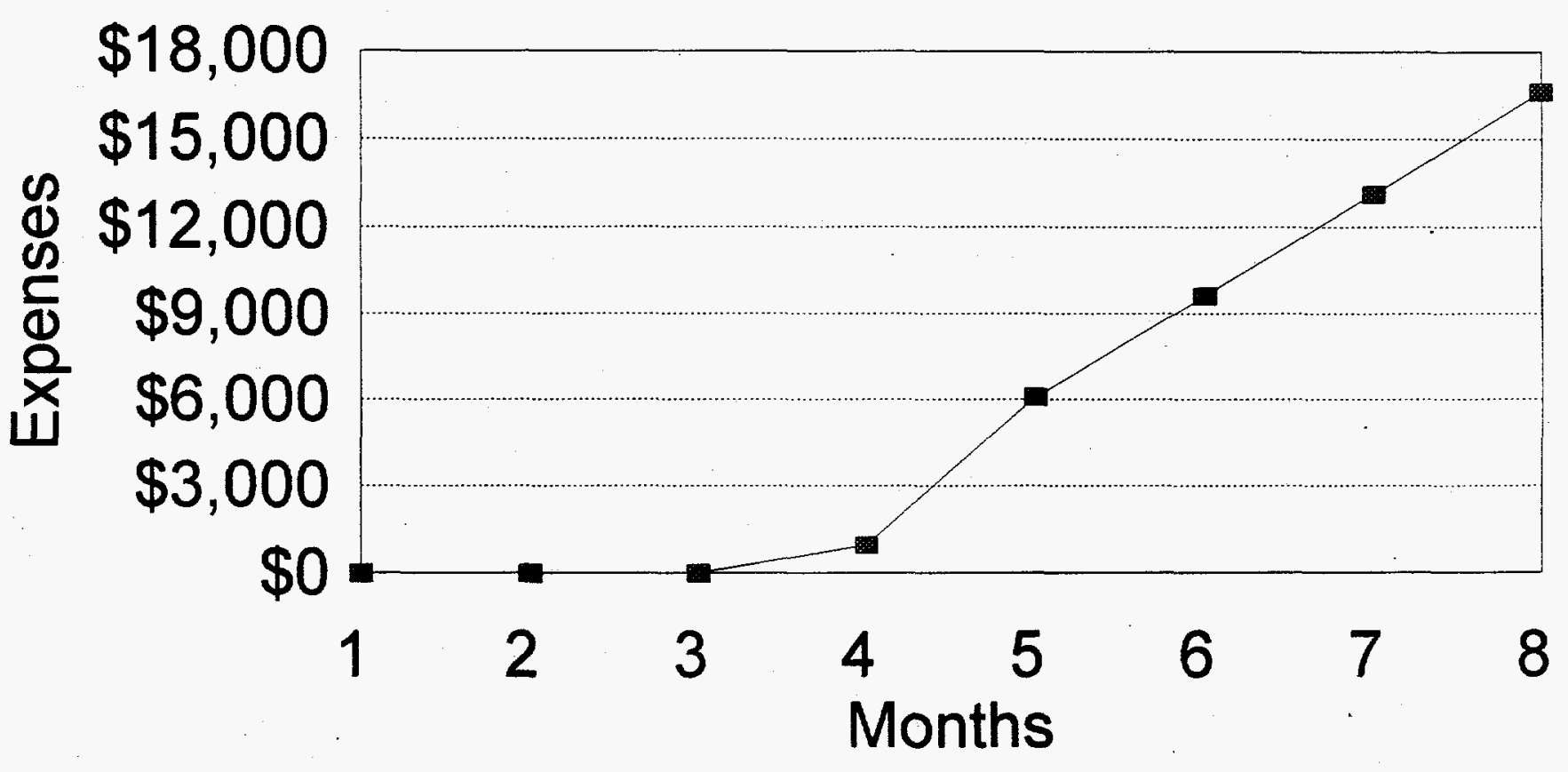

- Planned spending $\triangle$ Actual spending 
METC TASK \# : 2.3

MC-29

Capture of Hazardous Waste Materials Utilizing Fluidization Coating Technology

Period: January 1 - December 31, 1995

\begin{tabular}{|c|c|c|c|c|c|c|c|c|c|c|c|c|c|c|}
\hline . & $\begin{array}{c}1 \\
\text { January }\end{array}$ & $\stackrel{2}{2}$ & $\stackrel{3}{\text { March }}$ & $\begin{array}{c}4 \\
\text { April }\end{array}$ & $\begin{array}{c}5 \\
\text { May }\end{array}$ & $\begin{array}{c}6 \\
\text { June }\end{array}$ & $\begin{array}{l}7 \\
\text { July }\end{array}$ & $\begin{array}{c}8 \\
\text { August }\end{array}$ & $\stackrel{9}{9}$ & $\begin{array}{c}10 \\
\text { October }\end{array}$ & $\begin{array}{c}11 \\
\text { November }\end{array}$ & $\begin{array}{c}12 \\
\text { December }\end{array}$ & Projected Totals & Actual Totals \\
\hline $\begin{array}{l}\text { R. Turton (p) } \\
\text { Planned spending } \\
\text { R. Turton (a) } \\
\text { Actual spending }\end{array}$ & $\begin{array}{l}\$ 0.00 \\
\$ 0.00\end{array}$ & $\begin{array}{l}\$ 0.00 \\
\$ 0.00\end{array}$ & $\begin{array}{l}\$ 0.00 \\
\$ 0.00\end{array}$ & $\begin{array}{l}\$ 0.00 \\
\$ 0.00\end{array}$ & $\begin{array}{r}\$ 1,157.93 \\
\$ 0.00\end{array}$ & $\begin{array}{r}\$ 1,929.86 \\
\$ 0.00\end{array}$ & $\begin{array}{r}\$ 1,929.86 \\
\$ 0.00\end{array}$ & $\begin{array}{r}\$ 1,929.86 \\
\$ 0.00\end{array}$ & $\begin{array}{l}\$ 0.00 \\
\$ 0.00\end{array}$ & $\begin{array}{l}\$ 0.00 \\
\$ 0.00\end{array}$ & $\begin{array}{l}\$ 0.00 \\
\$ 0.00\end{array}$ & $\begin{array}{l}\$ 0.00 \\
\$ 0.00\end{array}$ & $\$ 6,947.51$ & $\$ 0.00$ \\
\hline $\begin{array}{c}\text { Graduate Student ( } p \text { ) } \\
\text { Planned spending } \\
\text { Graduate Student (a) } \\
\text { Actual spending }\end{array}$ & $\$ 0.00$ & $\begin{array}{l}\$ 0.00 \\
\$ 0.00\end{array}$ & $\begin{array}{l}\$ 0.00 \\
\$ 0.00\end{array}$ & $\begin{array}{r}\$ 858.00 \\
\$ 0.00\end{array}$ & $\begin{array}{r}\$ 1,072.50 \\
. \$ 0.00\end{array}$ & $\$ 1.072 .50$ & $\begin{array}{r}\$ 1.072 .50 \\
\$ 0.00\end{array}$ & $\begin{array}{r}\$ 1,072.50 \\
\$ 0.00\end{array}$ & $\begin{array}{l}\$ 0.00 \\
\$ 0.00\end{array}$ & $\begin{array}{l}\$ 0.00 \\
\$ 0.00\end{array}$ & $\begin{array}{l}\$ 0.00 \\
\$ 0.00\end{array}$ & $\begin{array}{l}\$ 0.00 \\
\$ 0.00\end{array}$ & $\$ 5,148.00$ & $\$ 0.00$ \\
\hline $\begin{array}{l}\text { Supplies (p) } \\
\text { Supplies (a) Planned spending } \\
\text { Actual spending }\end{array}$ & $\begin{array}{l}\$ 0.00 \\
\$ 0.00\end{array}$ & $\begin{array}{l}\$ 0.00 \\
\$ 0.00\end{array}$ & $\begin{array}{l}\$ 0.00 \\
\$ 0.00\end{array}$ & $\begin{array}{r}\$ 102.16 \\
\$ 0.00\end{array}$ & $\begin{array}{r}\$ 510.71 \\
\$ 0.00\end{array}$ & $\begin{array}{r}\$ 510.71 \\
\$ 0.00\end{array}$ & $\begin{array}{r}\$ 510.71 \\
\$ 0.00\end{array}$ & $\begin{array}{r}\$ 510.71 \\
\$ 0.00\end{array}$ & $\begin{array}{l}\$ 0.00 \\
\$ 0.00\end{array}$ & $\begin{array}{l}\$ 0.00 \\
\$ 0.00\end{array}$ & $\begin{array}{l}\$ 0.00 \\
\$ 0.00\end{array}$ & $\begin{array}{l}\$ 0.00 \\
\$ 0.00\end{array}$ & $\$ 2,145.00$ & $\$ 0.00$ \\
\hline $\begin{array}{l}\text { Equipment (p) } \\
\text { Planned spending } \\
\text { Equipment (a) } \\
\text { Actual spending }\end{array}$ & $\begin{array}{l}\$ 0.00 \\
\$ 0.00\end{array}$ & $\$ 0.00$ & $\$ 0.00$ & $\$ 0.00$ & $\begin{array}{r}\$ 2,400.00 \\
\$ 0.00\end{array}$ & $\begin{array}{l}\$ 0.00 \\
\$ 0.00\end{array}$ & $\begin{array}{l}\$ 0.00 \\
\$ 0.00\end{array}$ & $\begin{array}{l}\$ 0.00 \\
\$ 0.00\end{array}$ & $\begin{array}{l}\$ 0.00 \\
\$ 0.00\end{array}$ & $\begin{array}{l}\$ 0.00 \\
\$ 0.00\end{array}$ & $\begin{array}{l}\$ 0.00 \\
\$ 0.00\end{array}$ & $\begin{array}{l}\$ 0.00 \\
\$ 0.00\end{array}$ & $\$ 2,400.00$ & $\$ 0.00$ \\
\hline $\begin{array}{l}\text { Subcontracts (p) } \\
\text { Planned spending } \\
\text { Subcontracts (a) } \\
\text { Actual spending }\end{array}$ & $\begin{array}{l}\$ 0.00 \\
\$ 0.00\end{array}$ & $\begin{array}{l}\$ 0.00 \\
\$ 0.00\end{array}$ & $\begin{array}{l}\$ 0.00 \\
\$ 0.00\end{array}$ & $\begin{array}{l}\$ 0.00 \\
\$ 0.00\end{array}$ & $\begin{array}{l}\$ 0.00 \\
\$ 0.00\end{array}$ & $\begin{array}{l}\$ 0.00 \\
\$ 0.00\end{array}$ & $\begin{array}{l}\$ 0.00 \\
\$ 0.00\end{array}$ & $\begin{array}{l}\$ 0.00 \\
\$ 0.00\end{array}$ & $\begin{array}{l}\$ 0.00 \\
\$ 0.00\end{array}$ & $\begin{array}{r}\$ 400.00 \\
\$ 0.00\end{array}$ & $\begin{array}{r}\$ 200.00 \\
\$ 0.00\end{array}$ & $\begin{array}{l}\$ 0.00 \\
\$ 0.00\end{array}$ & $\$ 600.00$ & $\$ 0.00$ \\
\hline $\begin{array}{ll}\text { Travel (p) } & \text { Planned spending } \\
\text { Travel (a) } & \text { Actual spending }\end{array}$ & $\begin{array}{l}\$ 0.00 \\
\$ 0.00\end{array}$ & $\begin{array}{l}\$ 0.00 \\
\$ 0.00\end{array}$ & $\begin{array}{l}\$ 0.00 \\
\$ 0.00\end{array}$ & $\begin{array}{l}\$ 0.00 \\
\$ 0.00\end{array}$ & $\begin{array}{l}\$ 0.00 \\
\$ 0.00\end{array}$ & $\begin{array}{l}\$ 0.00 \\
\$ 0.00\end{array}$ & $\begin{array}{l}\$ 0.00 \\
\$ 0.00\end{array}$ & $\begin{array}{l}\$ 0.00 \\
\$ 0.00\end{array}$ & $\begin{array}{l}\$ 0.00 \\
\$ 0.00\end{array}$ & $\begin{array}{l}\$ 0.00 \\
\$ 0.00\end{array}$ & $\begin{array}{r}\$ 858.00 \\
\$ 0.00\end{array}$ & $\begin{array}{l}\$ 0.00 \\
\$ 0.00\end{array}$ & $\$ 858.00$ & $\$ 0.00$ \\
\hline Monthly Totals (Planned) & $\$ 0.00$ & 50.00 & $\$ 0.00$ & $\$ 960.16$ & $\$ 6,101.30$ & $\$ 9,614.37$ & $\$ 13,127.44$ & $\$ 16,640.51$ & $\$ 16,640.51$ & $\$ 17,040.51$ & $\$ 18,098.51$ & $\$ 18,098.51$ & $\$ 18,098.51$ & \\
\hline ACTUAL TOTALS & 50.00 & 50.00 & $\$ 0.00$ & $\$ 0.00$ & 50.00 & $\$ 0.00$ & $\$ 0.00$ & 50.00 & 50.00 & $\$ 0.00$ & $\$ 0.00$ & 50.00 & & $\$ 0.00$ \\
\hline
\end{tabular}

THIS AUDGET REFLECTS THE AWARD OF 60\% OF THE TOTAL PROJECTS BUDGET (awarded 3/13/95). 
METC TASK \#: 2.3

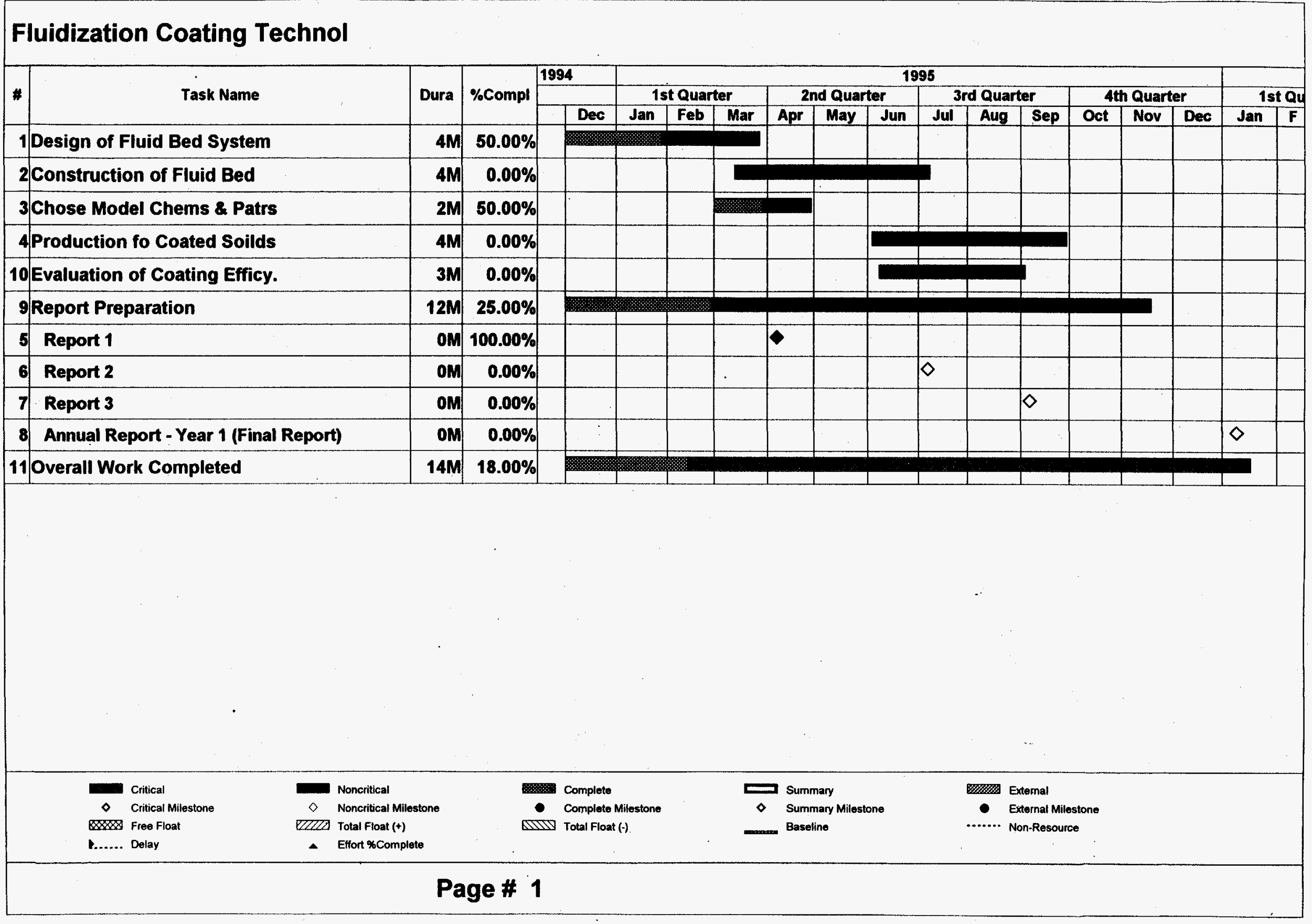


METC TASK \#: 2.5: Carbon Products for Waste Stream Cleanup

\section{MC- 17 Expenses Novel Forms of Carbon}

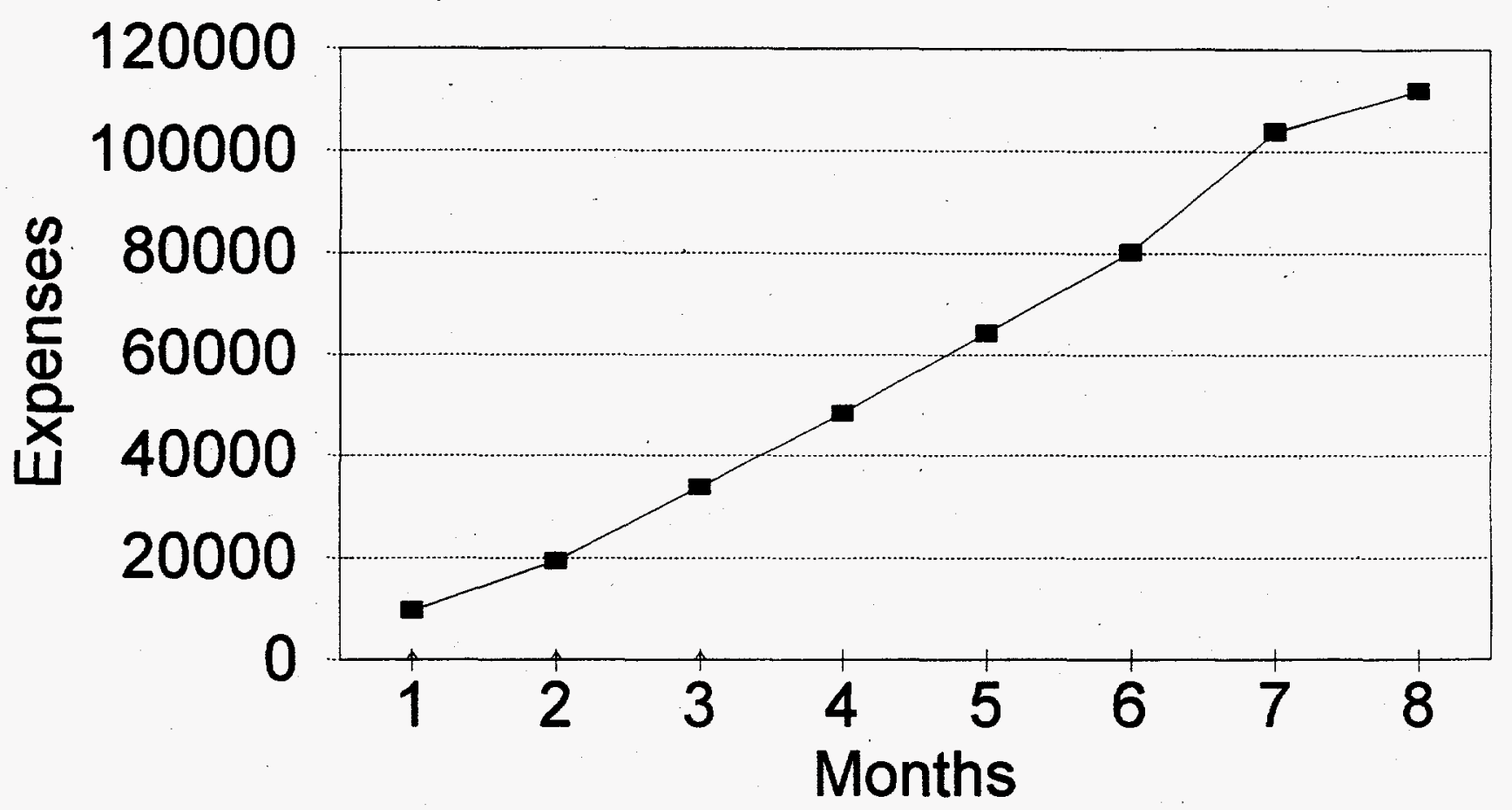

- Planned spending $\triangle$ Actual spending 
MC-17

Novil Forms of Carbon
Period: Jemuany 1 -Docember 31, 1995

\begin{tabular}{|c|c|c|c|c|c|c|c|c|c|c|c|c|c|c|c|}
\hline \multirow[b]{2}{*}{$\begin{array}{l}\text { NRCCE STAFF } \\
\text { C. Irwin (p) }\end{array}$} & & \multirow[t]{2}{*}{$\begin{array}{c}1 \\
\text { January }\end{array}$} & \multirow[t]{2}{*}{$\stackrel{2}{\text { Fobruary }}$} & \multirow[t]{2}{*}{$\begin{array}{l}3 \\
\text { March }\end{array}$} & \multirow[t]{2}{*}{ April } & \multirow[t]{2}{*}{ May } & \multirow[t]{2}{*}{ June } & \multirow[t]{2}{*}{$\begin{array}{l}7 \\
\text { July }\end{array}$} & \multirow[t]{2}{*}{$\stackrel{B}{\text { Auguat }}$} & \multirow[t]{2}{*}{ Soptember } & \multirow[t]{2}{*}{$\begin{array}{c}10 \\
\text { October }\end{array}$} & \multirow[t]{2}{*}{$\begin{array}{c}11 \\
\text { Novomber }\end{array}$} & \multirow[t]{2}{*}{$\begin{array}{c}12 \\
\text { Decomber }\end{array}$} & Projected rotals & Actual Totals \\
\hline & Plarned spending & & & & & & & & & & & & & $\$ 2,869.98$ & \\
\hline C. Irwin (a) & Actual spending & $\$ 0.00$ & 50.00 & $\$ 0.00$ & $\mathbf{s 0 . 0 0}$ & so. 00 & $\$ 0.00$ & $\$ 0.00$ & 50.00 & $\$ 0.00$ & 50.00 & $\$ 0.00$ & $\mathbf{s 0 . 0 0}$ & & $\$ 0.00$ \\
\hline M. Rode (p) & Plarned spending & $\$ 0.00$ & $\$ 0.00$ & 50.00 & 50.00 & $\$ 393.75$ & $\$ 393.75$ & $\$ 393.75$ & $\$ 393.75$ & $\$ 0.00$ & $\$ 0.00$ & $\$ 0.00$ & $\$ 0.00$ & $\$ 1.575 .00$ & \\
\hline (I) & Actual spending & $\$ 0.00$ & 50.00 & 50.00 & $\$ 0.00$ & 50.00 & $\$ 0.00$ & $\$ 0.00$ & $\$ 0.00$ & 50.00 & 50.00 & 50.00 & 50.00 & & 50.00 \\
\hline Socretary (p) & Plamed spending & 50.00 & $\$ 0.00$ & $\$ 0.00$ & $\$ 0.00$ & $\$ 594.00$ & $\$ 594.00$ & $\$ 594.00$ & $\$ 0.00$ & $\$ 0.00$ & 50.00 & $\$ 0.00$ & $\$ 0.00$ & $\$ 1,782.00$ & \\
\hline का & Actual spending & 50.00 & 50.00 & 50.00 & 50.00 & 50.00 & $\$ 0.00$ & 50.00 & 50.00 & 50.00 & 50.00 & 50.00 & 50.00 & & 50.00 \\
\hline$\frac{\text { ChE STAFF }}{\lambda \text { Sillor (p) }}$ & & & & & & & & & & & & & & & \\
\hline A stiller (e) & Planned spending & $\$ 0.00$ & 50.00 & $\$ 0.00$ & 50.00 & $\$ 0.00$ & $\$ 0.00$ & $\$ 2.832 .36$ & $\$ 0.00$ & $\$ 0.00$ & $\$ 0.00$ & $\$ 0.00$ & $\$ 0.00$ & $\mathbf{\$ 2 , 8 3 2 . 3 5}$ & \\
\hline & Actual spending & $\$ 0.00$ & $\$ 0.00$ & $\$ 0.00$ & 50.00 & 50.00 & 50.00 & 50.00 & 50.00 & 50.00 & 50.00 & 50.00 & $\$ 0.00$ & & $\$ 0.00$ \\
\hline J. Zondlo (p) & Plarned spending & $\$ 0.00$ & 50.00 & $\$ 0.00$ & $\$ 0.00$ & $\$ 0.00$ & $\$ 0.00$ & $\$ 2,882.16$ & $\mathbf{5 0 . 0 0}$ & $\$ 0.00$ & 50.00 & 50.00 & $\$ 0.00$ & $\$ 2,882.16$ & \\
\hline J.Zondilo (a) & Actual spending & $\$ 0.00$ & 50.00 & 50.00 & 50.00 & 50.00 & 50.00 & $\$ 0.00$ & 50.00 & $\$ 0.00$ & $\$ 0.00$ & 50.00 & 50.00 & & $\$ 0.00$ \\
\hline P. Stanebory (p) & Ptamed spending & $\$ 0.00$ & 50.00 & $\$ 3,254.05$ & $\$ \mathbf{\$ 3 , 2 5 4 , 0 5}$ & $\$ \$ 3,254.05$ & $\$ 3,254.05$ & $\$ 3,254.05$ & $\$ 3.254 .05$ & $\$ 0.00$ & $\$ 0.00$ & $\$ 0.00$ & $\$ 0.00$ & $\$ 19,524,30$ & \\
\hline 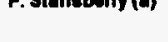 & Actual spending & 50.00 & $\$ 0.00$ & $\$ 0.00$ & $\$ 0.00$ & $\$ 0.00$ & $\$ 0.00$ & 50.00 & $\$ 0.00$ & $\$ 0.00$ & $\$ 0.00$ & $\$ 0.00$ & $\$ 0.00$ & & $\$ 0.00$ \\
\hline socretary (p) & Planned spending & $\$ 0.00$ & $\$ 0.00$ & $\$ 0.00$ & $\$ 0.00$ & $\$ 594.00$ & $\$ 594.00$ & $\$ 594.00$ & 50.00 & $\mathbf{5 0 . 0 0}$ & 50.00 & 50.00 & $\$ 0.00$ & $\$ 1.782 .00$ & \\
\hline - & Actual spending & $\$ 0.00$ & $\$ 0.00$ & $\$ 0.00$ & $\$ 0.00$ & $\$ 0.00$ & $\$ 0.00$ & $\$ 0.00$ & 50.00 & 50.00 & 50.00 & so. 00 & 50.00 & & 50.00 \\
\hline$\frac{\text { Chemiatry STAFF }}{\text { H. Finklea (D) }}$ & & & & & & & & & & & & & & & \\
\hline HElnklea & Plamed spending & 50.00 & $\$ 0.00$ & 50.00 & $\$ 0.00$ & $\$ 0.00$ & $\$ 0.00$ & $\$ 1,914.80$ & $\$ 0.00$ & $\$ 0.00$ & $\$ 0.00$ & $\$ 0.00$ & $\$ 0.00$ & $\$ 1.914 .80$ & \\
\hline (1) & Actual spending & 50.00 & $\$ 0.00$ & 50.00 & $\$ 0.00$ & $\$ 0.00$ & 50.00 & 50.00 & $\$ 0.00$ & $\$ 0.00$ & $\$ 0.00$ & $\$ 0.00$ & 50.00 & & $\$ 0.00$ \\
\hline Techniclan (p) & Plarnod spending & $\$ 0.00$ & 50.00 & $\$ 1,552.68$ & $\$ 1,552.68$ & 51.552 .68 & $\$ 1,552.68$ & $\$ 1,552.68$ & $\$ 1,552.68$ & 50.00 & 50.00 & 50.00 & $\$ 0.00$ & 59.316 .08 & \\
\hline 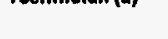 & Actual spending & $\$ 0.00$ & 50.00 & $\$ 0.00$ & 50.00 & 50.00 & $\$ 0.00$ & 50.00 & 50.00 & $\$ 0.00$ & 50.00 & 50.00 & $\$ 0.00$ & & 50.00 \\
\hline Grad. Aneilutant ( & P) Planned spending & $\$ 648.53$ & $\$ 648.53$ & $\$ 648.53$ & $\$ 648.53$ & $\$ 648.53$ & $\$ 648.53$ & 5648.53 & $\$ 0.00$ & $\$ 0.00$ & $\$ 0.00$ & $\$ 0.00$ & $\$ 0.00$ & $\$ 4,539.71$ & \\
\hline Grad. Asosiant & Actual spending & 50.00 & 50.00 & $\$ 0.00$ & $\$ 0.00$ & $\$ 0.00$ & 50.00 & 50.00 & so. 00 & $\$ 0.00$ & $\$ 0.00$ & 50.00 & $\$ 0.00$ & & so.00 \\
\hline Suppliee (p) & Plemed spending & $\$ 1,029.60$ & $\$ 1,029.60$ & $\$ 1,029.60$ & $\$ 1,029.60$ & $\$ 1,029.60$ & $\$ 1,029.60$ & $\$ 1,029.60$ & $\$ 0.00$ & $\$ 0.00$ & $\$ 0.00$ & $\$ 0.00$ & $\$ 0.00$ & $\$ 7,207.20$ & \\
\hline (1) & Actual spending & 50.00 & $\$ 0.00$ & $\$ 0.00$ & $\$ 0.00$ & $\$ 0.00$ & 50.00 & $\$ 0.00$ & $\$ 0.00$ & $\$ 0.00$ & $\$ 0.00$ & $\$ 0.00$ & $\$ 0.00$ & & $\$ 0.00$ \\
\hline PSU Subcontract & (p) & $\$ 7.977 .77$ & $\$ 7,977.77$ & \$7,977.77 & $\$ 7.977 .77$ & $\$$ & $\$ 7,977.77$ & $\$ 7,977.77$ & $\$ 0.00$ & $\$ 0.00$ & $\$ 0.00$ & $\$ 0.00$ & $\$ 0.00$ & $\$ 55,844.39$ & \\
\hline PSO SWoeOnt & Actual spending & $\$ 0.00$ & 50.00 & 50.00 & $\$ 0.00$ & 50.00 & 50.00 & $\$ 0.00$ & $\$ 0.00$ & $\$ 0.00$ & $\$ 0.00$ & $\$ 0.00$ & $\$ 0.00$ & & 50.00 \\
\hline Monthly rotas & S(Planned) & $39,655.00$ & $310,311.00$ & $533,774.43$ & $348,237,00$ & $304,281.44$ & $390,325.12$ & $\$ 103,999.51$ & $\$ 112,068.97$ & $\$ 112,060.97$ & $\$ 112,008.97$ & $\$ 112,069.87$ & $\$ 712,069.97$ & $3112,055.97$ & \\
\hline ACTUAL TOTA & ALS & 50.00 & 80.00 & 80.00 & 90.00 & 30.00 & 50.00 & $\$ 0.00$ & $\$ 0.00$ & $\$ 0.00$ & 30.00 & 30.00 & 30.00 & & 30.00 \\
\hline
\end{tabular}

THIS BUDGET REFLECTS THE AWARD OF 6O\% OF THE TOTAL PROJECTS BUDOET (aWanded 3/13/95). 


\section{MC-17}

\begin{tabular}{|c|c|c|c|c|c|c|c|c|c|c|c|c|c|c|c|c|c|c|c|c|c|c|c|c|c|c|c|}
\hline \multirow{3}{*}{ * } & \multirow{3}{*}{ Task Name } & \multirow{3}{*}{ Dura } & \multirow{3}{*}{ XCompl } & \multicolumn{4}{|l|}{1994} & \multicolumn{12}{|c|}{1995} & \multicolumn{8}{|c|}{1996} \\
\hline & & & & & & Quan & & & Quar & & & Quar & & & Quart & & & Quart & & & Quart & & & Q Quan & & & \\
\hline \multirow{2}{*}{\multicolumn{28}{|c|}{ 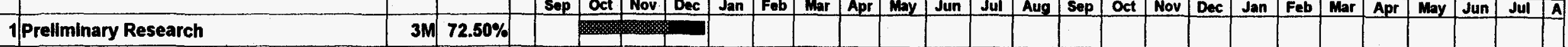 }} \\
\hline & & & & & & & & & & & & & & & & & & & & & & & & & & & \\
\hline \multicolumn{28}{|c|}{2 Electrochemical Remediation (ECR) } \\
\hline \multicolumn{28}{|c|}{3 Technical Evaluation } \\
\hline \multicolumn{28}{|c|}{4 Analytical Techniques } \\
\hline \multicolumn{28}{|c|}{5 Preparation for Trials } \\
\hline \multicolumn{28}{|c|}{6 Hire Post-Doctoral } \\
\hline \multicolumn{28}{|c|}{ Purchase Electrochemical System } \\
\hline \multicolumn{28}{|c|}{ Obtain Chemicais and Reagents } \\
\hline \multicolumn{28}{|c|}{ Obtain Carbon Samples } \\
\hline 10 & \multicolumn{27}{|l|}{ Characterize Carbon Samples } \\
\hline \multicolumn{28}{|c|}{$8 \mathrm{M} 32.86 \%$} \\
\hline 12. & \multicolumn{27}{|l|}{ ECR-Sample A } \\
\hline 13 & \multicolumn{27}{|l|}{ ECR-Sample B } \\
\hline 14 & \multicolumn{27}{|l|}{ ECR-Sample C } \\
\hline 10 & ECR-Sample D & $8 \mathrm{M}$ & $10.00 \%$ & & & & & & & & & & & & & & & & & & & & & & & & \\
\hline 16 & ECR-Sample E & 8M & $10.00 \%$ & & & & & & & & & & & & & & & & & & & & & & & & \\
\hline 17 & ECR-Sample F & 6M & $0.00 \%$ & & & & & & & & & & & & & & & & & & & & & & & & \\
\hline 18. & Trial Repeats (concurrent) & $4 M$ & $20.00 \%$ & & & & & & & & & & & & & & & & & & & & & & & & \\
\hline 18 & Analysis and Reporting & $11 \mathrm{M}$ & $57.50 \%$ & & & & & & & & & & & & & & & & & & & & & & & & \\
\hline 20 & Analysis and Data Reduction & $2 \mathrm{M}$ & $40.00 \%$ & & & & & & & & & & & & & & & & & & & & & & & & \\
\hline 21. & Reports and Manuscripts & $11 \mathrm{M}$ & $76.00 \%$ & & & & & & & & & & & & & & & & & & & & & & & & \\
\hline 22 & Overall Work Complete & 12M & $59.77 \%$ & & & & & & & & & & & & & & & & & & & & & & & & \\
\hline
\end{tabular}
22. Overall Work Complete

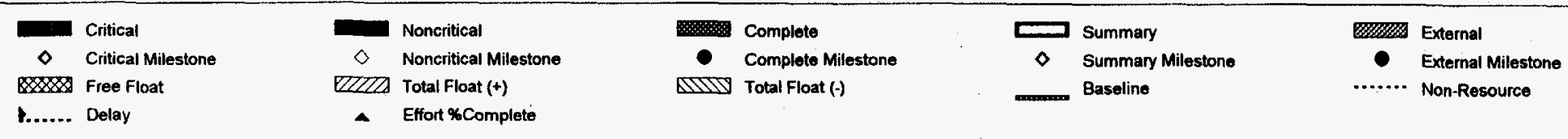

Page \# 1 


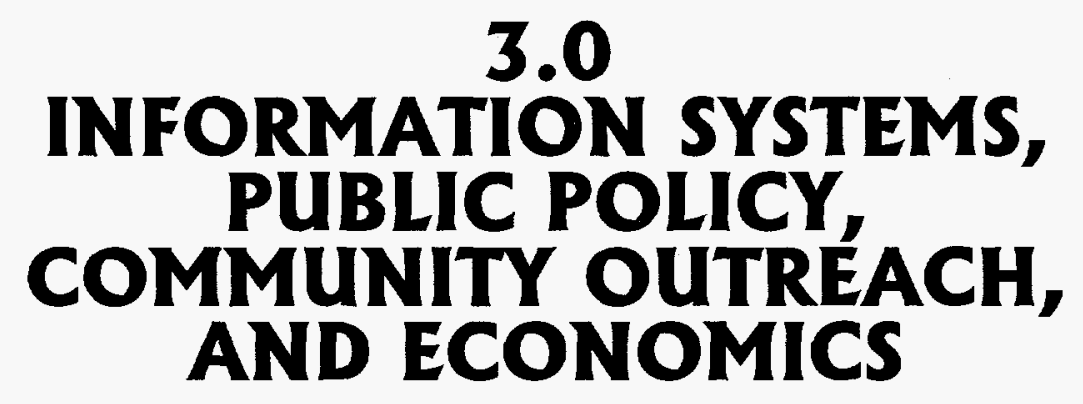

$-57-$ 

METC TASK \#: 3.1: Winfield Lock and Dam Assistance Program
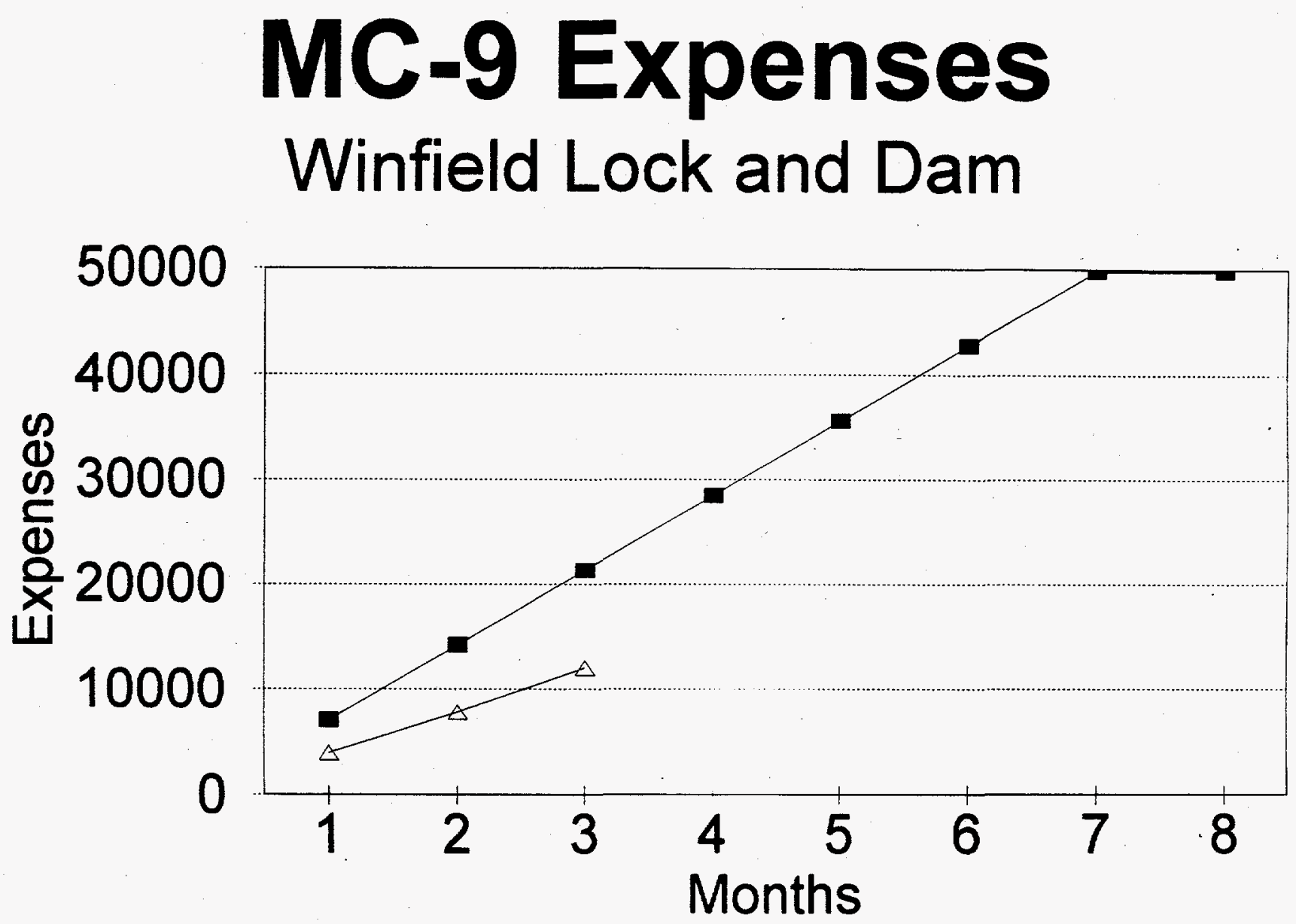

- Planned spending - Actual spending 
METC TASK \#: 3.1

MC-9

Winfletd Lock \& Dam
Period: January 1 - December 31, 1996

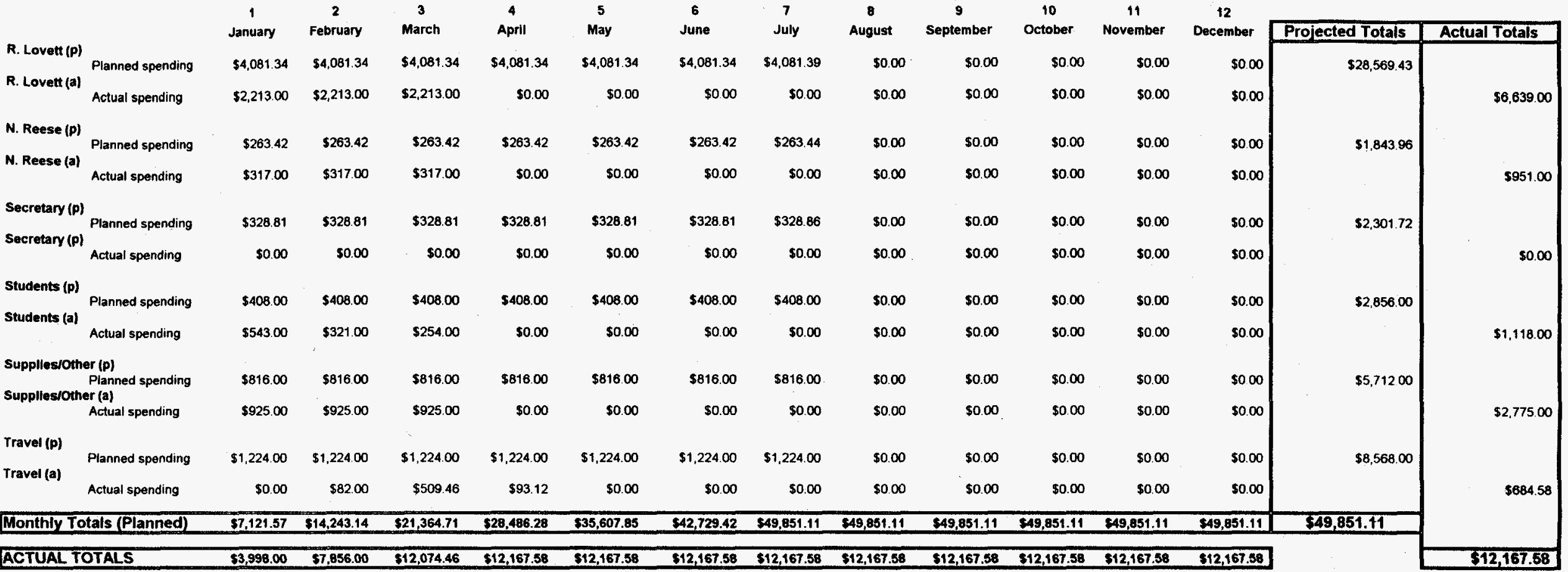

THIS BUDGET REFLECTS THE AWARID OF GO\% OF THE TOTAL PROJECTS BUDGET (aWarded 3/13/95). 
METC TASK \#: 3.1

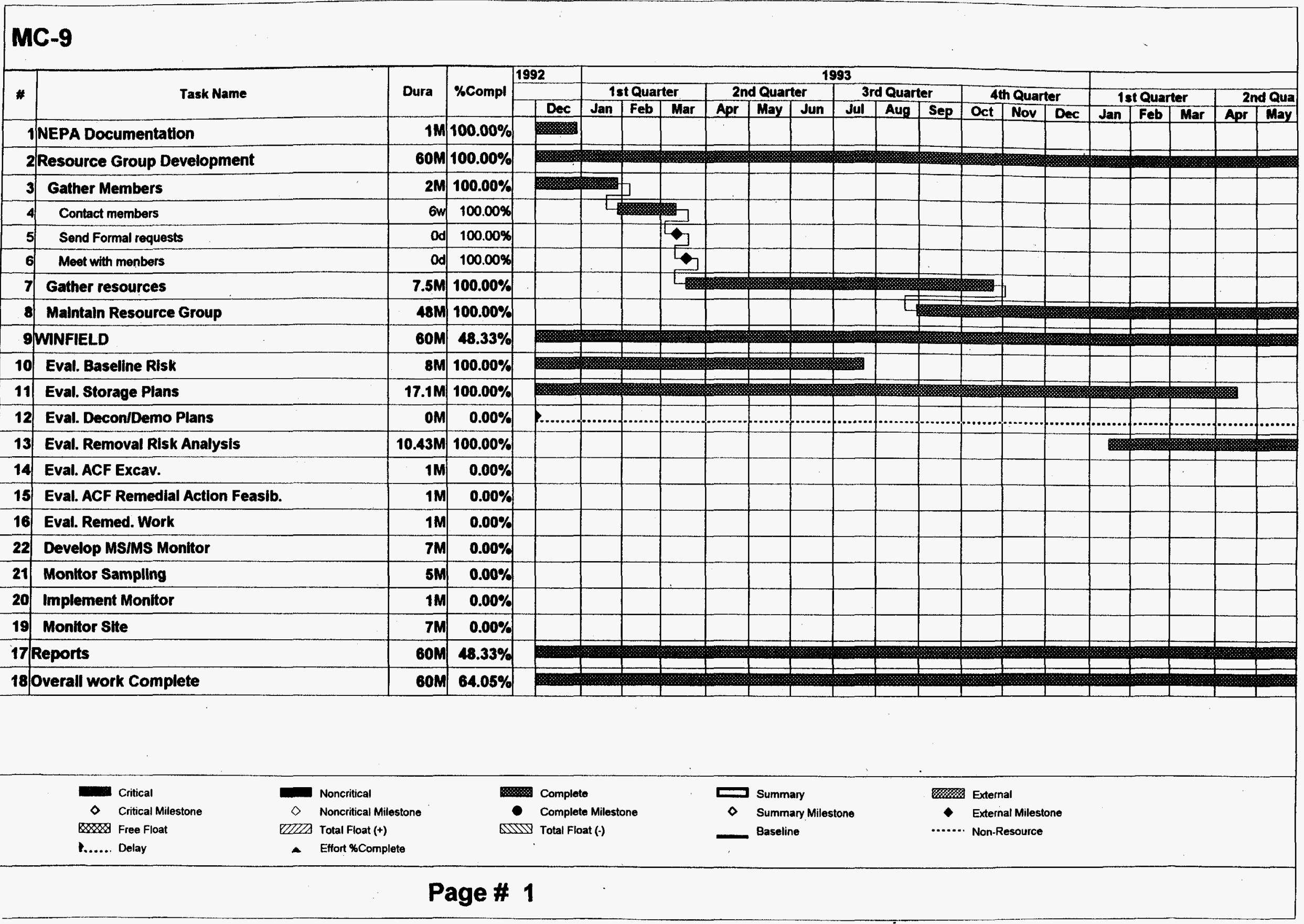


METC TASK \# : 3.1

\section{MC-9}

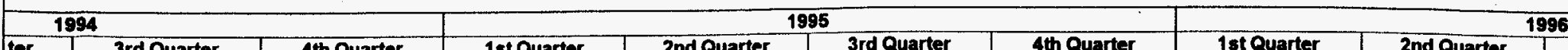

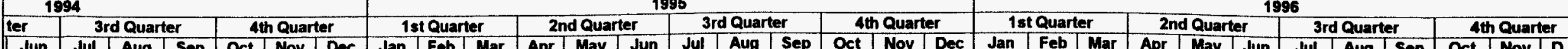

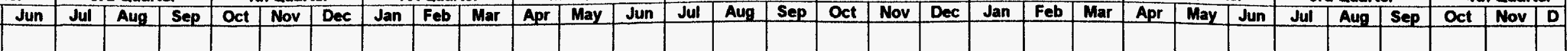
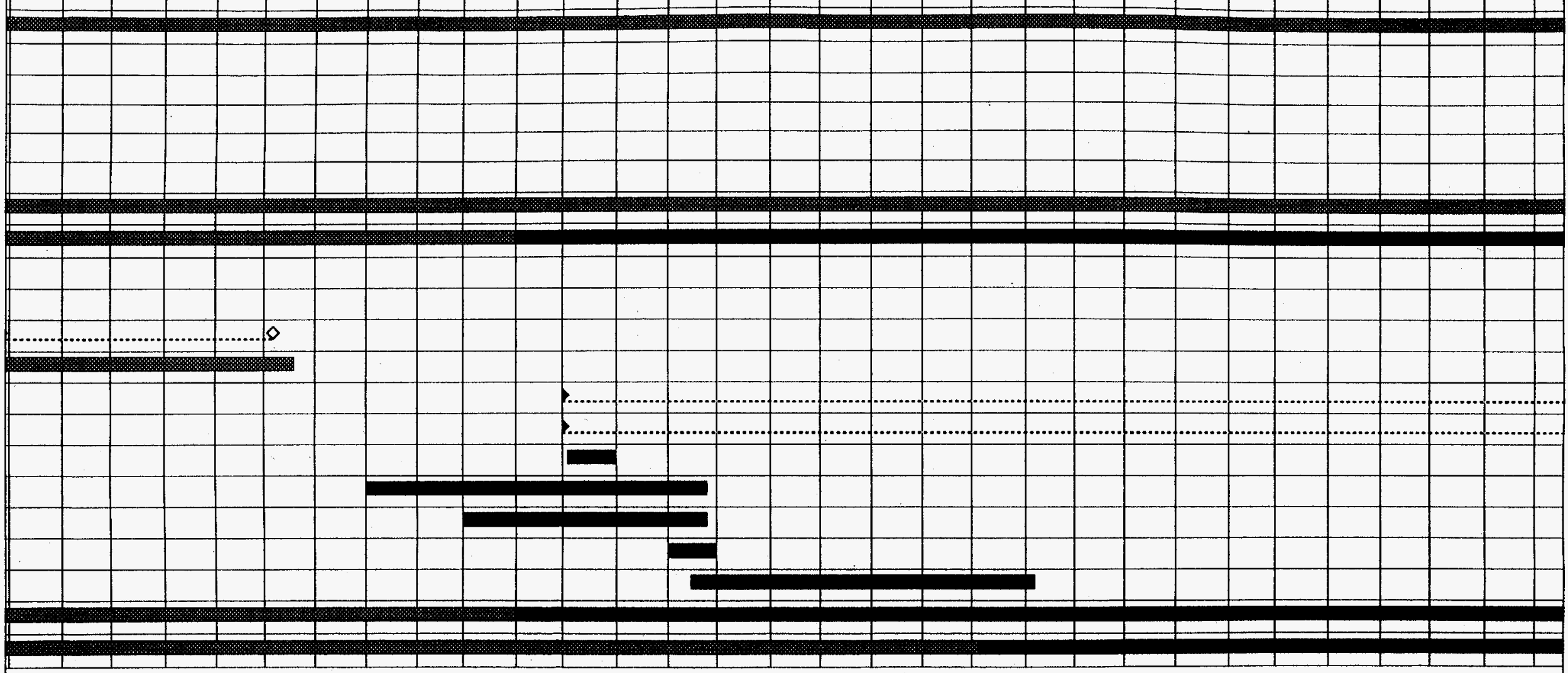

Critical
$\diamond \quad$ Critical Milestone
Free Float

1...... Delay

Noncritical
$\diamond \quad$ Noncritical Milestone
LZZZJ Total Float ( + )

- Ellort \%Complete
Complete

- Complete Milestone

Total Float (-)
Summary
- Summary Milestone
Baseline
Ex] External

- External Milestone

....... Non-Resource

Page \# 2 
METC TASK \#: 3.1

\section{MC-9}

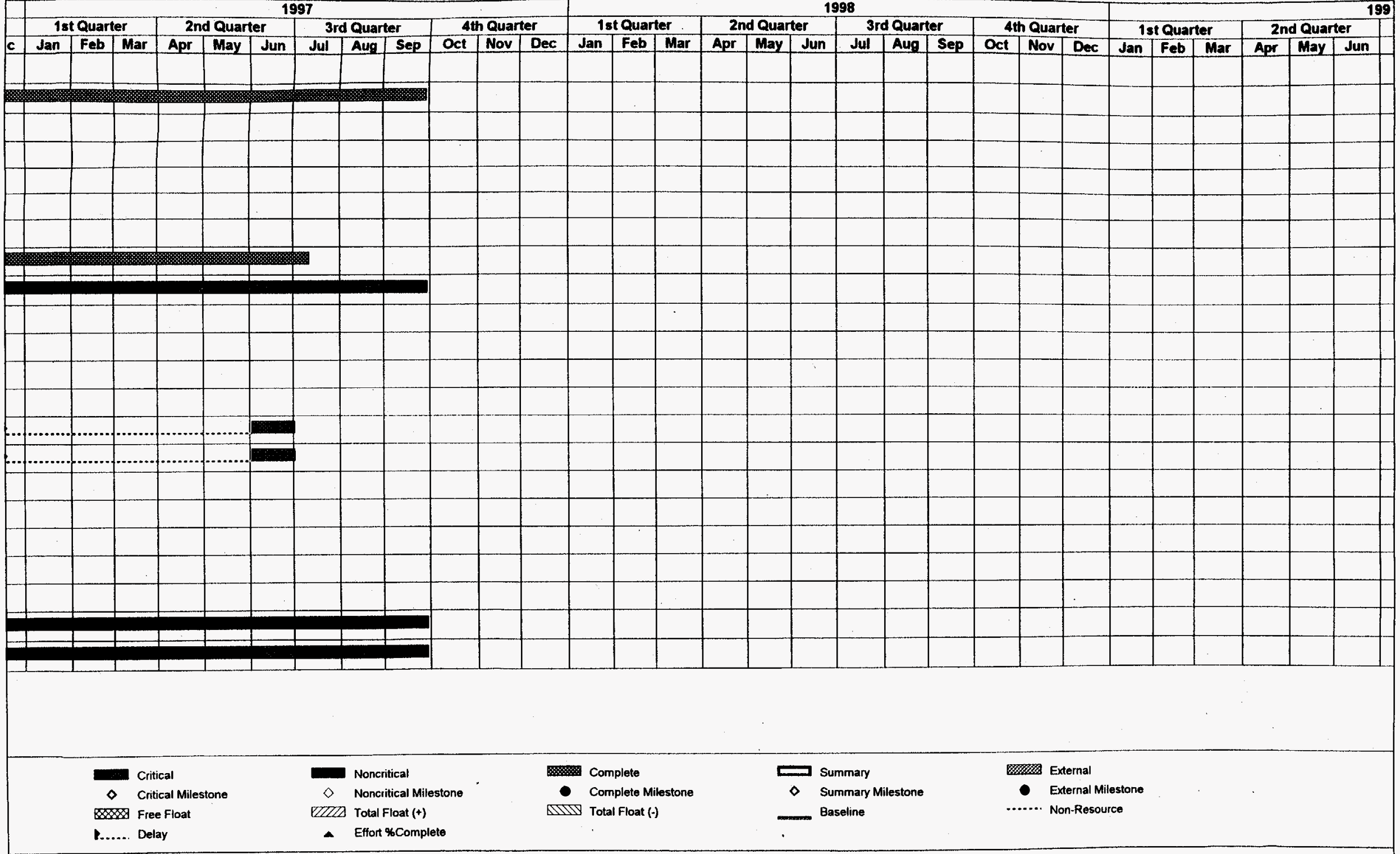

Page \# 3 
A GIS Based Infrastructure for Site Characterization and Remediation PRINCIPAL INVESTIGATOR: Dr. E.E. COOKMWU - METC TASK NO. 3.2

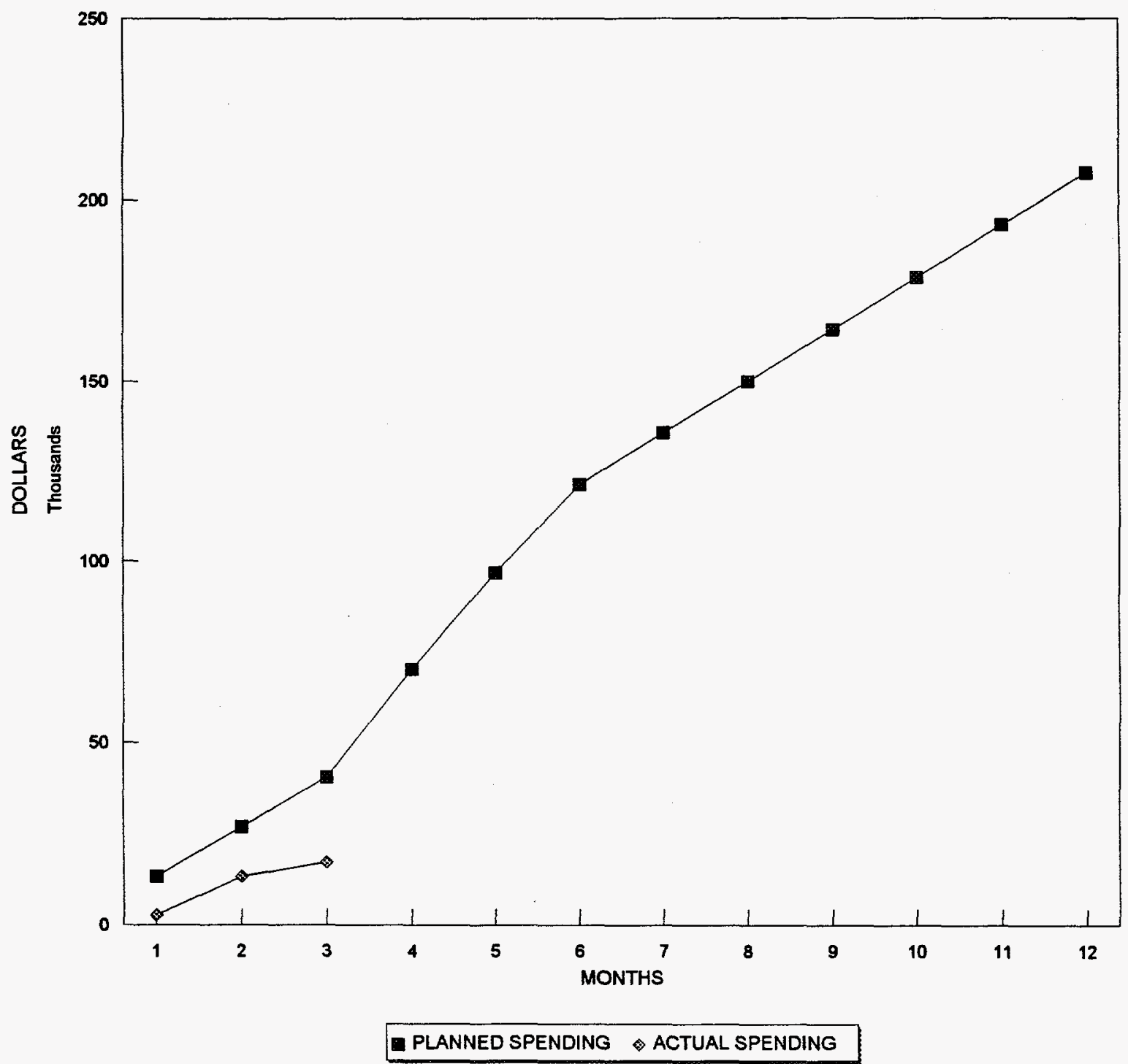

Marshall University - Overall Budget: 


\section{PROJECT: A GIS Based Infrastructure for Site Characterization and Remediation}

METC TASK NO.: 3.2

PRINCIPAL INVESTIGATIOR: E.E. Cook

PERIOD ENGING: 3/31/95

(**Marshall University - Overall Budget)

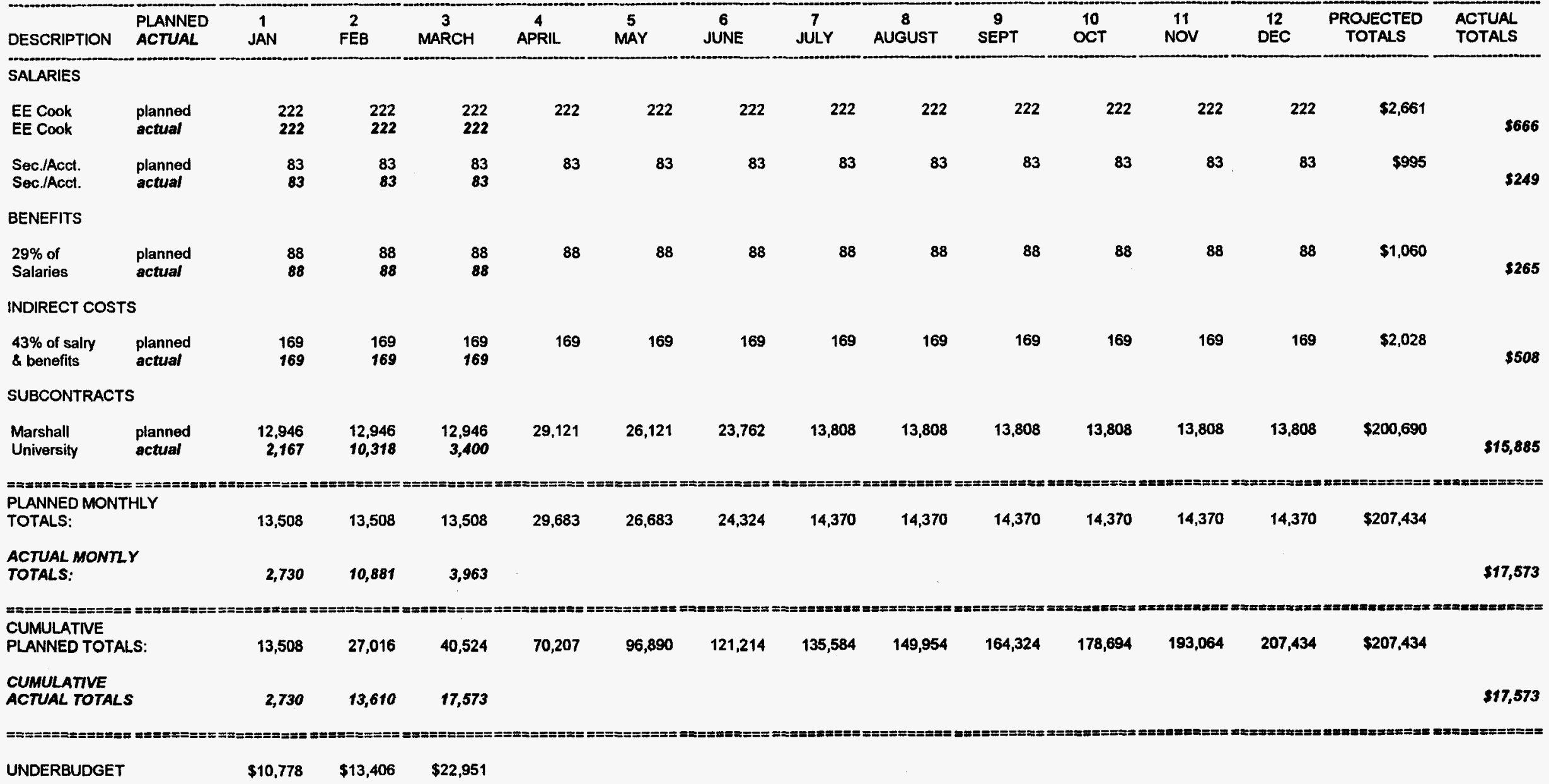




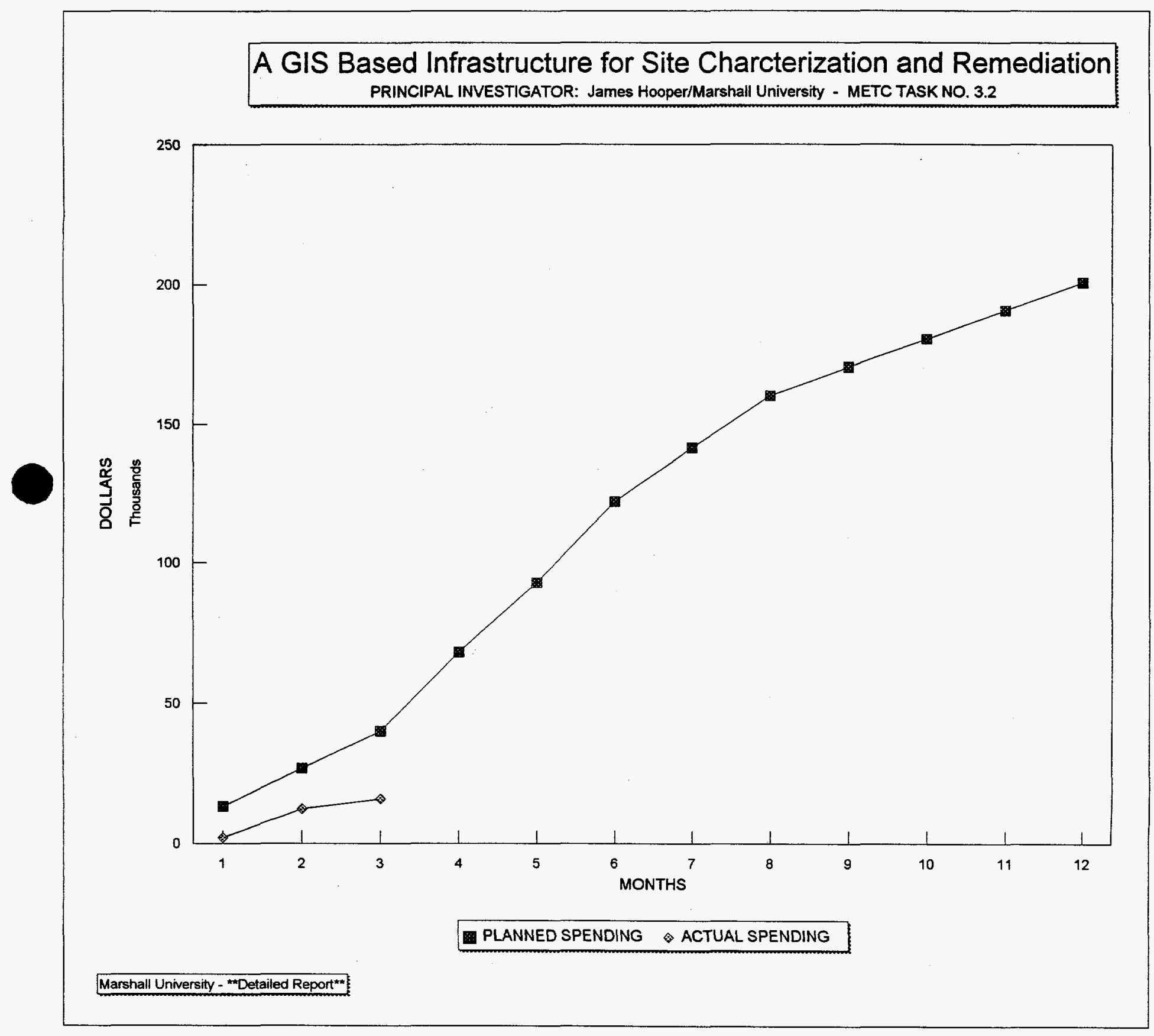


PROJECT: A GIS Based Infrastructure for Site Characterization and Remediation

MECT TASK NO:: 3.2

PRINCIPAL INVESTIGATOR: James Hooper * *** MARSHALL UNIVERSITY - DETAILED REPORT ***

PERIOD ENDING: March 31, 1995

\begin{tabular}{|c|c|c|c|c|c|c|c|c|c|c|c|c|c|c|c|}
\hline DESCRIPTION & $\begin{array}{l}\text { PLANNED } \\
\text { ACTUAL }\end{array}$ & $\begin{array}{l}1 \\
\text { JAN }\end{array}$ & $\stackrel{2}{\text { FEB }}$ & $\stackrel{3}{3}$ & $\stackrel{4}{4}$ & $\begin{array}{l}5 \\
\text { MAY }\end{array}$ & $\begin{array}{l}6 \\
\text { JUNE }\end{array}$ & $\begin{array}{l}7 \\
\text { JULY }\end{array}$ & $\begin{array}{c}8 \\
\text { AUGUST }\end{array}$ & $\stackrel{9}{9}$ & $\begin{array}{c}10 \\
\text { OCT }\end{array}$ & $\begin{array}{l}11 \\
\text { NOV }\end{array}$ & $\begin{array}{c}12 \\
\text { DEC }\end{array}$ & $\begin{array}{l}\text { PROJECTED } \\
\text { TOT.ALS }\end{array}$ & $\begin{array}{l}\text { ACTUAL } \\
\text { TOTALS }\end{array}$ \\
\hline \multicolumn{16}{|l|}{ LABOR COST } \\
\hline $\begin{array}{l}\text { Direct } \\
\text { Labor }\end{array}$ & $\begin{array}{l}\text { planned } \\
\text { actual }\end{array}$ & $\begin{array}{l}6,687 \\
1,208\end{array}$ & $\begin{array}{l}6,687 \\
3,148\end{array}$ & $\begin{array}{l}6,687 \\
1,895\end{array}$ & 6,687 & 6,687 & 8,937 & 8,937 & 8,937 & 5,000 & 5,000 & 5,000 & 5,000 & $\$ 80,247$ & $\$ 6,251$ \\
\hline $\begin{array}{l}\text { Student } \\
\text { Labor }\end{array}$ & $\begin{array}{l}\text { planned } \\
\text { actual }\end{array}$ & 0 & 0 & 0 & 0 & 0 & 2,000 & 2,000 & 1,500 & 500 & 500 & 500 & 500 & $\$ 7,500$ & so \\
\hline \multicolumn{16}{|l|}{ BENEFITS } \\
\hline $\begin{array}{l}30 \% \text { of } \\
\text { Direct Labor }\end{array}$ & $\begin{array}{l}\text { planned } \\
\text { actual }\end{array}$ & $\begin{array}{r}2,006 \\
362\end{array}$ & $\begin{array}{r}2,006 \\
944\end{array}$ & $\begin{array}{r}2,006 \\
569\end{array}$ & $\begin{array}{r}2,006 \\
0\end{array}$ & $\begin{array}{r}2,006 \\
0\end{array}$ & $\begin{array}{r}2,681 \\
0\end{array}$ & $\begin{array}{r}2,681 \\
0\end{array}$ & $\begin{array}{r}2,681 \\
0\end{array}$ & $\begin{array}{r}1,500 \\
0\end{array}$ & $\begin{array}{r}1,500 \\
0\end{array}$ & $\begin{array}{r}1,500 \\
0\end{array}$ & $\begin{array}{r}1,500 \\
0\end{array}$ & $\$ 24,074$ & $\$ 1,875$ \\
\hline \multicolumn{16}{|l|}{ EQUIPMENT } \\
\hline $\begin{array}{l}1 \text { - Computers, } \\
\text { Printers, ect }\end{array}$ & $\begin{array}{l}\text { planned } \\
\text { actual }\end{array}$ & 0 & 0 & 0 & 11,000 & 8,000 & 6,000 & 0 & 0 & 0 & 0 & 0 & 0 & $\$ 25,000$ & $\$ 0$ \\
\hline 2-Software & $\begin{array}{l}\text { planned } \\
\text { actual }\end{array}$ & 0 & 0 & 0 & 2,500 & 2,500 & 2,240 & 0 & 0 & 0 & 0 & 0 & 0 & $\$ 7,240$ & $\$ 0$ \\
\hline \multicolumn{16}{|l|}{ OTHER } \\
\hline $\begin{array}{l}\text { Phone, Travel, } \\
\text { Reports, Misc. }\end{array}$ & $\begin{array}{l}\text { planned } \\
\text { actual }\end{array}$ & 1,000 & $\begin{array}{r}1,000 \\
3385\end{array}$ & 1,000 & 1,000 & 1,000 & 1,000 & 500 & 500 & 500 & 250 & 250 & 250 & $\$ 8,250$ & $\$ 3,385$ \\
\hline \multicolumn{16}{|l|}{ INDIRECT COSTS } \\
\hline $\begin{array}{l}38 \% \text { of exp } \\
\text { Exc Equip-1 }\end{array}$ & $\begin{array}{l}\text { planned } \\
\text { actual }\end{array}$ & $\begin{array}{r}3,683 \\
597\end{array}$ & $\begin{array}{l}3,683 \\
2,841\end{array}$ & $\begin{array}{r}3,683 \\
936\end{array}$ & $\begin{array}{r}4,633 \\
0\end{array}$ & $\begin{array}{r}4,633 \\
0\end{array}$ & $\begin{array}{r}6,406 \\
0\end{array}$ & $\begin{array}{r}5,365 \\
0\end{array}$ & $\begin{array}{r}5,175 \\
0\end{array}$ & $\begin{array}{r}2,850 \\
0\end{array}$ & $\begin{array}{r}2,755 \\
0\end{array}$ & $\begin{array}{r}2,755 \\
0\end{array}$ & $\begin{array}{r}2,755 \\
0\end{array}$ & $\$ 48,378$ & $\$ 4,374$ \\
\hline =" & $=== \pm$ & 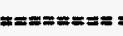 & $======8$ & $==x=== \pm=$ & 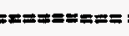 & $=====$ & $=====$ & $== \pm=x==5$ & $==== \pm==$ & $=== \pm==-=$ & $:=====-=$ & $:= \pm====$ & $==== \pm=8$ & $:=== \pm==m z$ & 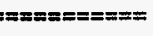 \\
\hline $\begin{array}{l}\text { PLANNED TOTALS: } \\
\text { PER MONTH }\end{array}$ & & 13,377 & 13,377 & 13,377 & 27,827 & 24,827 & 29,264 & 19,483 & 18,793 & 10,350 & 10,005 & 10,005 & 10,005 & $\$ 200,689$ & \\
\hline $\begin{array}{l}\text { ACTUAL TOTALS: } \\
\text { PER MONTH } \\
==============\end{array}$ & & 2,167 & 10,318 & 3,400 & 0 & 0 & 0 & 0 & 0 & 0 & 0 & 0 & 0 & 0 & 15,885 \\
\hline $\begin{array}{l}\text { CUMULATIVE } \\
\text { PLANNED TOTALS: }\end{array}$ & & 13,377 & 26,754 & 40,130 & 67,957 & 92,784 & 122,048 & 141,531 & 160,324 & 170,674 & 180,679 & 190,684 & 200,689 & $\$ 200,689$ & \\
\hline $\begin{array}{l}\text { CUMULATIVE } \\
\text { ACTUAL TOTALS } \\
=====1\end{array}$ & & $\begin{array}{l}2,167 \\
=\geq= \pm=x=\end{array}$ & $\begin{array}{l}12,486 \\
======\end{array}$ & $\begin{array}{c}15,885 \\
== \pm= \pm= \pm=\end{array}$ & $=====$ & $\begin{array}{c}15,885 \\
:===== \pm==\end{array}$ & 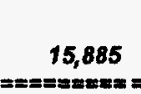 & $\begin{array}{c}15,885 \\
:== \pm= \pm= \pm= \pm=\end{array}$ & 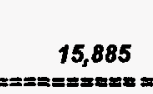 & $\begin{array}{c}15,885 \\
== \pm= \pm= \pm=x\end{array}$ & $\begin{array}{c}15,885 \\
== \pm== \pm= \pm=\end{array}$ & $\begin{array}{c}15,885 \\
=== \pm= \pm=\end{array}$ & $\begin{array}{c}15,885 \\
10===\end{array}$ & $====x=12 x=1=0=$ & $\$ 15,885$ \\
\hline UNDER BUDGET & & $\$ 11,210$ & $\$ 14,268$ & $\$ 24,245$ & $\$ 52,072$ & $\$ 76,899$ & $\$ 106,163$ & $\$ 125,646$ & $\$ 144,439$ & $\$ 154,789$ & $\$ 164,794$ & $\$ 174,799$ & $\$ 184,804$ & & \\
\hline
\end{tabular}


METC TASK \#: 3.2

GIS-BASED INFRASTRUCTURE FOR SITE CHARACTERIZATION AND REMEDIATION

\begin{tabular}{|c|c|c|c|c|c|c|c|c|c|c|c|c|c|}
\hline$\#$ & Task Name & $\begin{array}{l}\text { 1s } \\
\text { Qt }\end{array}$ & $\begin{array}{l}\text { t } \\
\text { t }\end{array}$ & & $\begin{array}{l}2 n \\
Q t\end{array}$ & & & $\begin{array}{l}3 r \\
Q t\end{array}$ & & & $\begin{array}{l}4 t \\
Q t\end{array}$ & & \\
\hline & & $\begin{array}{l}\mathrm{J} \\
\mathrm{a} \\
\mathrm{n}\end{array}$ & $\begin{array}{l}F \\
\text { e } \\
b\end{array}$ & $\begin{array}{l}\mathrm{M} \\
\mathrm{a} \\
\mathrm{r}\end{array}$ & $\begin{array}{l}\mathrm{A} \\
\mathrm{p} \\
\mathrm{r}\end{array}$ & $\begin{array}{l}\mathrm{M} \\
\mathrm{a} \\
\mathrm{y}\end{array}$ & $\begin{array}{l}\mathrm{J} \\
\mathrm{u} \\
\mathrm{n}\end{array}$ & $\begin{array}{l}\mathrm{J} \\
\mathrm{u} \\
\mathrm{I}\end{array}$ & $\begin{array}{l}\mathrm{A} \\
\mathrm{u} \\
\mathrm{g}\end{array}$ & $\begin{array}{l}\mathrm{s} \\
\mathrm{e} \\
\mathrm{p}\end{array}$ & $\begin{array}{l}0 \\
c \\
t\end{array}$ & $\begin{array}{l}N \\
0 \\
V\end{array}$ & $\begin{array}{l}\mathrm{D} \\
\mathrm{e} \\
\mathrm{C}\end{array}$ \\
\hline 1 & NEPA Documentation & 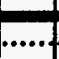 & 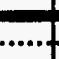 & 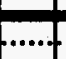 & & & & & & & & & \\
\hline 2 & System Requirements & ..... & 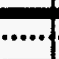 & $\cdots .$. & & & & & & & & & \\
\hline 3 & Devise and specify system Requirements & $\cdots .$. & 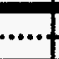 & $\cdots \cdot$ & & & & & & & & & \\
\hline 4 & Determine Operating Procedures & & & & & & & & & & & & \\
\hline 5 & Develop Materials for Technology Transfer & & & & & & & & & & & & \\
\hline
\end{tabular}

Planned: $-\quad$ Actual: ………....... 


\section{Small Business Program - Administrative Budget}

PRINCIPAL INVESTIGATOR: Dr. E.E. Cook - METC TASK NO. 3.3

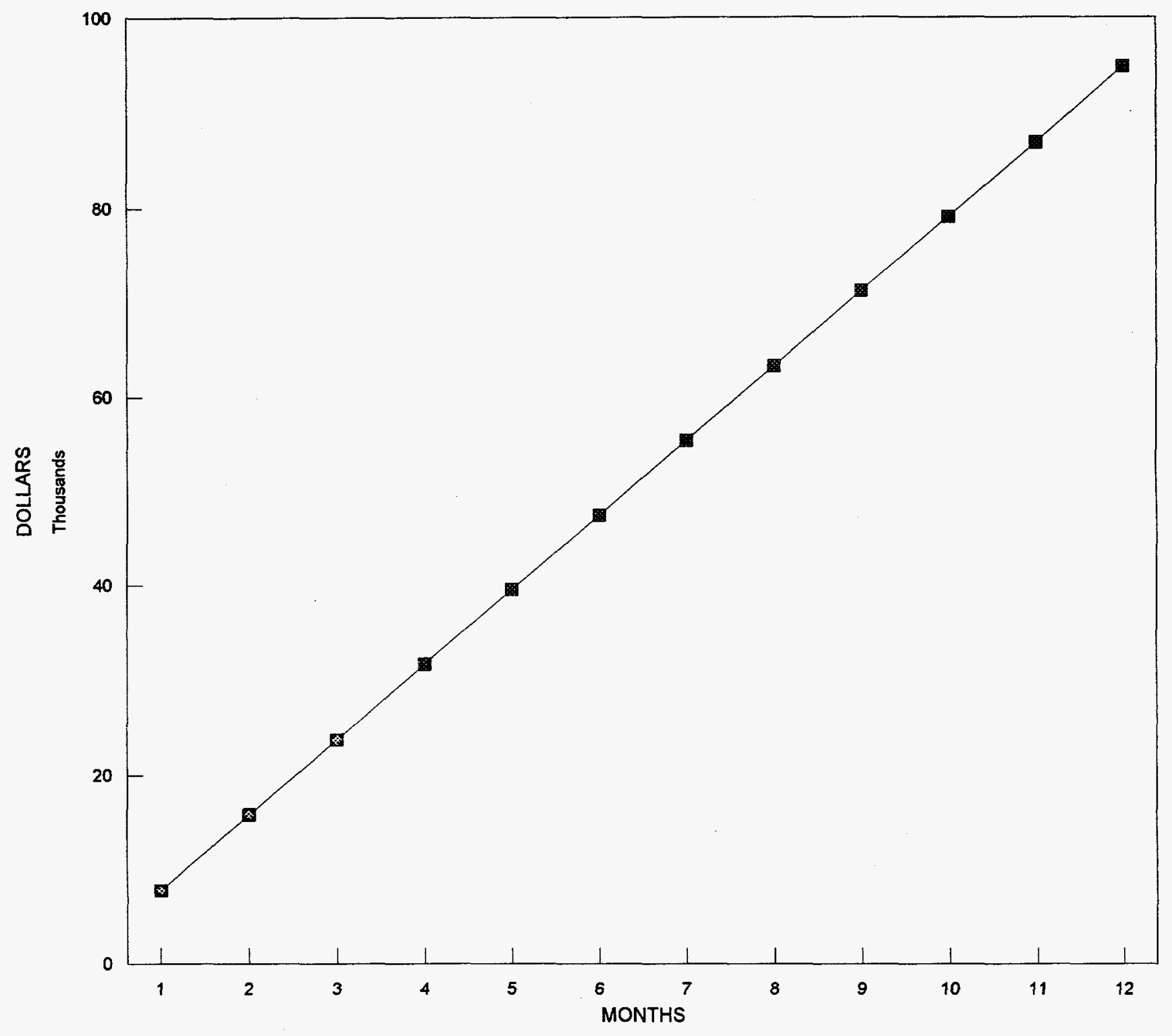

PLANNED TOTALS ACTUAL TOTALS 


\section{PROJECT: Small Business Program Administrative Budget}

\section{METC TASK NO.: 3.3}

\section{PRINCIPAL INVESTIGATIOR: E.E. CoOk}

\section{PERIOD ENGINGmaster}

\begin{tabular}{|c|c|c|c|c|c|c|c|c|c|c|c|c|c|c|c|}
\hline DESCRIPTION & $\begin{array}{l}\text { PLANNED } \\
\text { ACTUAL }\end{array}$ & $\stackrel{1}{\text { JAN }}$ & $\stackrel{2}{2}$ & $\stackrel{3}{3}$ & $\stackrel{4}{4}$ & $\stackrel{5}{\text { MAY }}$ & $\begin{array}{l}6 \\
\text { JUNE }\end{array}$ & $\stackrel{7}{\text { JULY }}$ & $\stackrel{8}{8}$ & $\stackrel{9}{\text { SEPT }}$ & $\begin{array}{c}10 \\
\text { OCT }\end{array}$ & $\begin{array}{c}11 \\
\text { NOV }\end{array}$ & $\begin{array}{c}12 \\
D E C\end{array}$ & $\begin{array}{l}\text { PROJECTED } \\
\text { TOTALS }\end{array}$ & $\begin{array}{l}\text { ACTUAL } \\
\text { TOTALS }\end{array}$ \\
\hline \multicolumn{16}{|l|}{ SALARIES } \\
\hline Director & $\begin{array}{l}\text { planned } \\
\text { actual }\end{array}$ & $\begin{array}{l}1,535 \\
1,535\end{array}$ & $\begin{array}{l}1,535 \\
1,535\end{array}$ & $\begin{array}{l}1,535 \\
1,535\end{array}$ & 1,535 & 1,535 & 1,535 & 1,535 & 1,535 & 1,535 & 1,535 & 1,535 & 1.535 & $\$ 18,414$ & $\$ 4,604$ \\
\hline $\begin{array}{l}\text { Technical } \\
\text { Assistant }\end{array}$ & $\begin{array}{l}\text { planned } \\
\text { actual }\end{array}$ & $\begin{array}{l}2,334 \\
2,334\end{array}$ & $\begin{array}{l}2,334 \\
2,334\end{array}$ & $\begin{array}{l}2,334 \\
\mathbf{2 , 3 3 4}\end{array}$ & 2,334 & 2,334 & 2,334 & 2,334 & 2,334 & 2,334 & 2,334 & 2,334 & 2,334 & $\$ 28,008$ & $\$ 7,002$ \\
\hline Secretary & $\begin{array}{l}\text { planned } \\
\text { actual }\end{array}$ & $\begin{array}{l}417 \\
417\end{array}$ & $\begin{array}{l}417 \\
417\end{array}$ & $\begin{array}{l}417 \\
417\end{array}$ & 417 & 417 & 417 & 417 & 417 & 417 & 417 & 417 & 417 & $\$ 5,000$ & $\$ 1,250$ \\
\hline \multicolumn{16}{|l|}{ BENEFITS } \\
\hline $\begin{array}{l}29 \% \text { On } \\
\text { Salaries }\end{array}$ & $\begin{array}{l}\text { planned } \\
\text { actual }\end{array}$ & $\begin{array}{l}1,243 \\
1,243\end{array}$ & $\begin{array}{l}1,243 \\
1,243\end{array}$ & $\begin{array}{l}1,243 \\
1,243\end{array}$ & 1,243 & 1,243 & 1,243 & 1,243 & 1,243 & 1,243 & 1,243 & 1,243 & 1,243 & $\$ 14,912$ & $\$ 3,728$ \\
\hline \multicolumn{16}{|l|}{ INDIRECT COSTS } \\
\hline $43 \%$ of $\exp$ & $\begin{array}{l}\text { planned } \\
\text { actual }\end{array}$ & $\begin{array}{l}2,377 \\
2,377\end{array}$ & $\begin{array}{l}2,377 \\
\mathbf{2 , 3 7 7}\end{array}$ & $\begin{array}{l}2,377 \\
2,377\end{array}$ & 2,377 & 2,377 & 2,377 & 2,377 & 2,377 & 2,377 & 2,377 & 2,377 & 2,377 & $\$ 28,524$ & $\$ 7,131$ \\
\hline $\begin{array}{c}\text { PLANNED TOTALS: } \\
\text { PER MONTH }\end{array}$ & & 7,905 & 7,905 & 7,905 & 7,905 & 7,905 & 7,905 & 7,905 & 7,905 & 7,905 & 7,905 & 7,905 & 7,905 & $\$ 94,858$ & \\
\hline $\begin{array}{l}\text { ACTUAL TOTALS: } \\
\text { PER MONTH } \\
========= \pm=====\end{array}$ & & $\begin{array}{r}7,905 \\
== \pm= \pm==\end{array}$ & $\begin{array}{r}7,905 \\
==== \pm=\end{array}$ & $\begin{array}{r}7,905 \\
= \pm= \pm= \pm==\end{array}$ & E===E & & $=====$ & & - & & 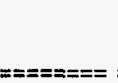 & $= \pm=$ & $z==\pi$ & 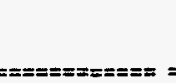 & $\begin{array}{r}\$ 23,715 \\
== \pm====\end{array}$ \\
\hline $\begin{array}{l}\text { CUMULATIVE } \\
\text { PLANNED TOTALS: }\end{array}$ & & 7,905 & 15,810 & 23,715 & 31,619 & 39,524 & 47,429 & 55,334 & 63,239 & 71,144 & 79,048 & 86,953 & 94,858 & $\$ 94,858$ & \\
\hline $\begin{array}{l}\text { CUMULATIVE } \\
\text { ACTUAL TOTALS }\end{array}$ & & 7,905 & 15,810 & 23,715 & & & & & & & & & & & $\$ 23,715$ \\
\hline
\end{tabular}

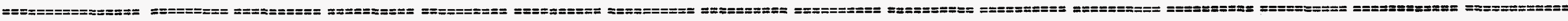

UNDER BUDGET

$(\$ 0) \quad(\$ 0) \quad(\$ 0)$ 
METC TASK \#: 3.3

\section{SMALL BUSINESS SUPPORT PROGRAM}

\begin{tabular}{|c|c|c|c|c|c|c|c|c|c|c|c|c|c|}
\hline \multirow[t]{2}{*}{$\#$} & \multirow[t]{2}{*}{ Task Name } & \multicolumn{3}{|c|}{$\begin{array}{l}\text { 1st } \\
\text { Qtr }\end{array}$} & \multicolumn{3}{|c|}{$\begin{array}{l}\text { 2nd } \\
\text { Qtr }\end{array}$} & \multicolumn{3}{|c|}{$\begin{array}{l}3 r d \\
\text { Qtr }\end{array}$} & \multicolumn{3}{|c|}{$\begin{array}{l}4 \text { th } \\
\text { Qtr }\end{array}$} \\
\hline & & $\begin{array}{l}\mathrm{J} \\
\mathrm{a} \\
\mathrm{n}\end{array}$ & $\begin{array}{l}\mathrm{F} \\
\mathrm{e} \\
\mathrm{b}\end{array}$ & $\begin{array}{l}\mathrm{M} \\
\mathrm{a} \\
\mathrm{r}\end{array}$ & $\begin{array}{l}\mathrm{A} \\
\mathrm{p} \\
\mathrm{r}\end{array}$ & $\begin{array}{l}\mathrm{M} \\
\mathrm{a} \\
\mathrm{Y}\end{array}$ & $\begin{array}{l}\mathbf{J} \\
\mathbf{u} \\
\mathbf{n}\end{array}$ & $\begin{array}{l}\mathrm{J} \\
\mathrm{u} \\
\mathrm{I}\end{array}$ & $\begin{array}{l}A \\
u \\
g\end{array}$ & $\begin{array}{l}s \\
e \\
p\end{array}$ & $\begin{array}{l}0 \\
c \\
t\end{array}$ & $\begin{array}{l}\mathbf{N} \\
\mathbf{0} \\
\mathbf{V}\end{array}$ & $\begin{array}{l}\text { D } \\
\text { e } \\
\text { C }\end{array}$ \\
\hline 1 & Interact with METC for Business Needs & .... & …0. & $\ldots .$. & & & & & & & & & \\
\hline 2 & Meet with Small Businesses & & .... & ...... & & & & & & & & & \\
\hline 3 & Develop Proposals with Small Businesses & & 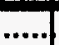 & ..... & & & & & & & & & \\
\hline
\end{tabular}

Planned:

Actual: ................. 
METC TASK \#: 3.4: Approach for Assessing Potential Voluntary Environmental

Protection - Kanawha River Area

\section{MC - 27 Expenses Kanawha Valley}

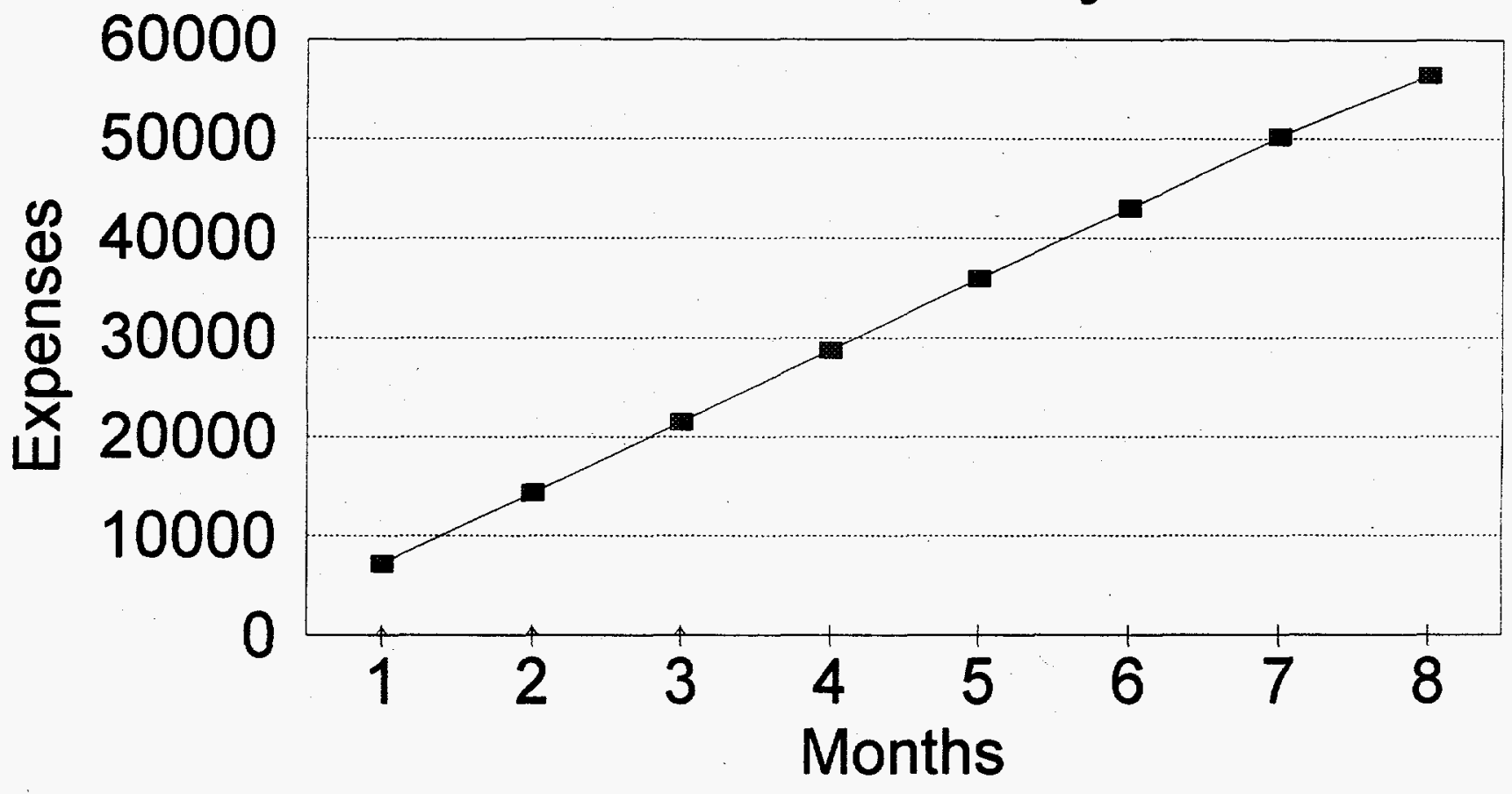

- - Planned spending $\triangle$ Actual spending 
METC TASK 3.4

MC-27

Mroject

Period: Jamuary 1-December 31, 1995

\begin{tabular}{|c|c|c|c|c|c|c|c|c|c|c|c|c|c|}
\hline $\begin{array}{c}1 \\
\text { January }\end{array}$ & $\begin{array}{c}2 \\
\text { February }\end{array}$ & $\begin{array}{c}3 \\
\text { March }\end{array}$ & $\begin{array}{c}4 \\
\text { April }\end{array}$ & $\begin{array}{c}5 \\
\text { May }\end{array}$ & $\begin{array}{c}6 \\
\text { June }\end{array}$ & $\begin{array}{l}7 \\
\text { July }\end{array}$ & $\begin{array}{c}8 \\
\text { August }\end{array}$ & $\begin{array}{c}9 \\
\text { September }\end{array}$ & $\begin{array}{c}10 \\
\text { October }\end{array}$ & $\begin{array}{c}11 \\
\text { November }\end{array}$ & $\begin{array}{c}12 \\
\text { December }\end{array}$ & Projected Totals & Actual Totals \\
\hline$\$ 80.07$ & $\$ 80.07$ & $\$ 80.07$ & $\$ 80.07$ & $\$ 80.07$ & $\$ 80.07$ & $\$ 80.07$ & $\$ 0.00$ & $\$ 0.00$ & $\$ 0.00$ & $\$ 0.00$ & $\$ 0.00$ & $\$ 560.49$ & \\
\hline$\$ 0.00$ & $\$ 0.00$ & $\$ 0.00$ & $\$ 0.00$ & $\$ 0.00$ & $\$ 0.00$ & $\$ 0.00$ & $\$ 0.00$ & $\$ 0.00$ & $\$ 0.00$ & $\$ 0.00$ & $\$ 0.00$ & & $\$ 0.00$ \\
\hline$\$ 6.206 .25$ & $\$ 6,206.25$ & $\$ 6,206.25$ & $\$ 6.206 .25$ & $\$ 6,206.25$ & $\$ 6,206.25$ & $\$ 6,206,25$ & $\$ 6,206.25$ & $\$ 0.00$ & $\$ 0.00$ & $\$ 0.00$ & $\$ 0.00$ & $\$ 49,650.00$ & \\
\hline$\$ 0.00$ & $\$ 0.00$ & $\$ 0.00$ & $\$ 0.00$ & $\$ 0.00$ & $\$ 0.00$ & $\$ 0.00$ & $\$ 0.00$ & $\$ 0.00$ & $\$ 0.00$ & $\$ 0.00$ & $\$ 0.00$ & & $\$ 0.00$ \\
\hline$\$ 896.75$ & $\$ 896.75$ & $\$ 896.75$ & $\$ 896.75$ & $\$ 896.75$ & $\$ 896.75$ & $\$ 896.75$ & $\$ 0.00$ & $\$ 0.00$ & $\$ 0.00$ & $\$ 0.00$ & $\$ 0.00$ & $\$ 6,277.25$ & \\
\hline$\$ 0.00$ & $\$ 0.00$ & $\$ 0.00$ & $\$ 0.00$ & $\$ 0.00$ & $\$ 0.00$ & $\$ 0.00$ & $\$ 0.00$ & $\$ 0.00$ & $\$ 0.00$ & $\$ 0.00$ & $\$ 0.00$ & & $\$ 0.00$ \\
\hline $97,183.07$ & $\$ 14,366.14$ & $\$ 21,549.21$ & $\mathbf{5 2 8 , 7 3 2 . 2 8}$ & $\$ 335,915.35$ & $\$ 43,098.42$ & $550,281.49$ & $\$ 56,487.74$ & $\$ 56.487 .74$ & $\$ 56,487.74$ & $\$ 56,487.74$ & $\$ 56,487.74$ & $\$ 56,487.74$ & \\
\hline 0.00 & 50.00 & 50.00 & 50.00 & 50.00 & 50.00 & $\$ 0.00$ & $\$ 0.00$ & 50.00 & $\$ 0.00$ & 50.00 & 50.00 & & 50.00 \\
\hline
\end{tabular}

\begin{tabular}{|lrrrrr}
\hline ACTUAL TOTALS & $\$ 0.00$ & 50.00 & $\$ 0.00$ & $\$ 0.00$ & $\$ 0.00$ \\
\hline
\end{tabular}

THIS QUDGET REFLECTS THE AWARD OF 60\% OF THE TOTAL PROJECTS BUDGET (awarded 3/13/95). 


\section{Kanawha River}

\begin{tabular}{|c|c|c|c|c|c|c|c|c|c|c|c|c|c|c|c|c|}
\hline \multirow{3}{*}{$\#$} & \multirow{3}{*}{ Task Name } & \multirow{3}{*}{ Dura } & \multirow{3}{*}{$\%$ Compl } & \multicolumn{12}{|c|}{1995} & \multirow[b]{3}{*}{ Ja } \\
\hline & & & & \multicolumn{3}{|c|}{ 1st Quarter } & \multicolumn{3}{|c|}{ 2nd Quarter } & \multicolumn{3}{|c|}{ 3rd Quarter } & \multicolumn{3}{|c|}{ 4th Quarter } & \\
\hline & & & & Jan & & Mar & Apr & May & Jun & Jul & Aug & Sep & Oct & Nov & Dec & \\
\hline 1 & Initial contact of private parties & $1 \mathrm{M}$ & $0.00 \%$ & & & & & & & & & & & & & \\
\hline 2 & Conduct confidential meetings with private parties & $1 M$ & $0.00 \%$ & & & & & & & & & & & & & \\
\hline 3 & Scoping meetings with USEPA Region 3 and WVDEP & $7 w$ & $0.00 \%$ & & & & & & & & & & & & & \\
\hline 4 & Prepare summary of meetings & $2 w$ & $0.00 \%$ & & & & & & & & & & & & & \\
\hline & Convene group meeting & $1 M$ & $0.00 \%$ & & & & & & & & & & & & & \\
\hline
\end{tabular}

Critical

cal Milestone

Free Float

1...... Delay
Noncritical
$0 \quad$ Noncritical Milestone
DIITA Total Float ( + )

EIfart \%Complet

\section{Completo}

- Complete Milestone

SIIIJ Total Float (-)

Summary
Summary Milestone
Baseline

External

- External Milostone

....... Non-Resource

Page \# 1 
EXTENDED BUDGETS

. 
$-76-$ 


\section{Soil Decontamination by Steam Reforming}

PRINCIPAL INVESTIGATOR: R. Lovett - METC TASK NO.: 2.4

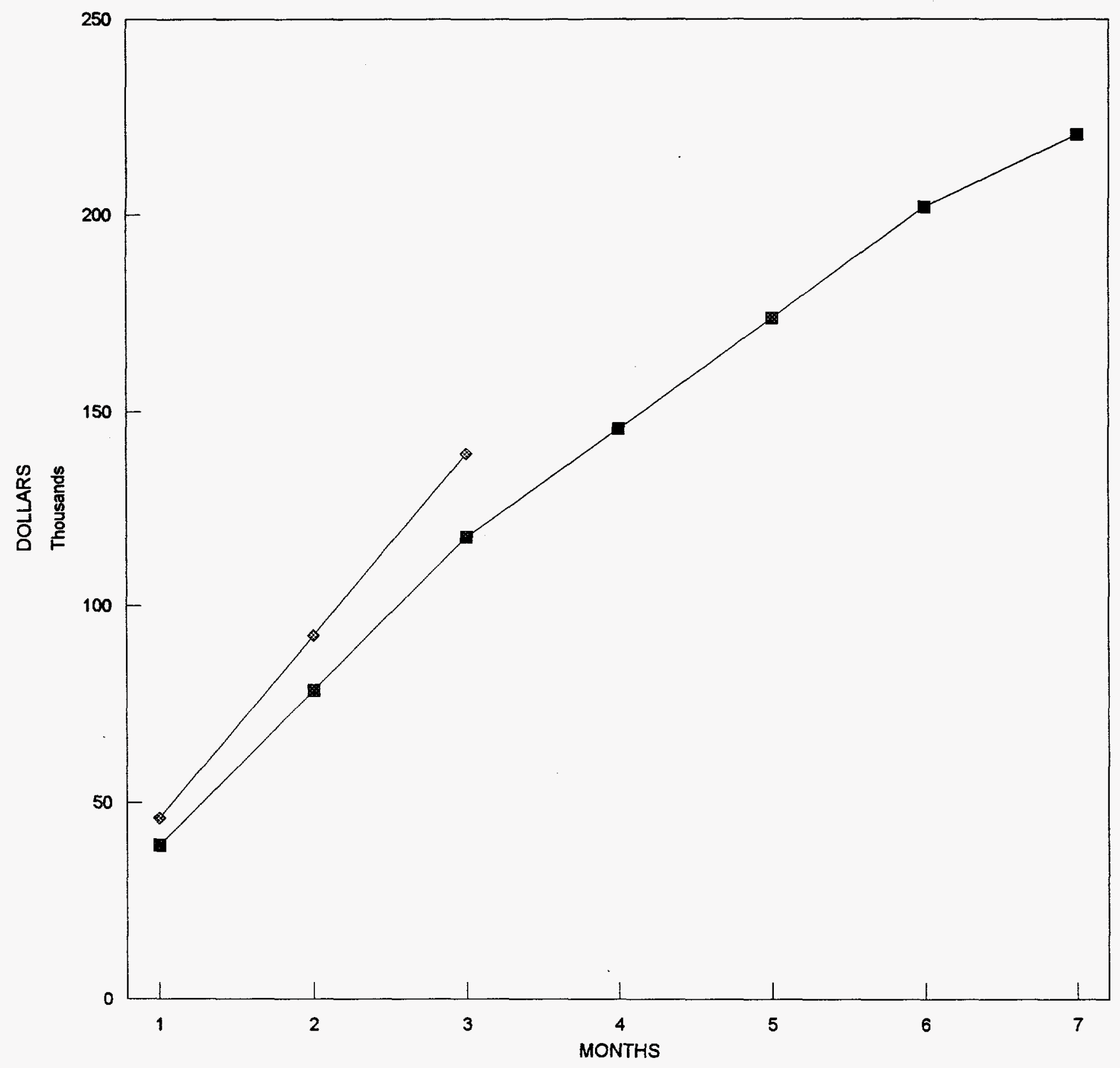

PLANNED SPENDING ACTUAL SPENDING

This budget reflects the award of $60 \%$ of the total projects budget (awarded 3/13/95) 


\section{PROJECT: Soil Decontamination by Steam Reforming}

\section{METC TASK NO.: 2.4}

\section{PRINCIPAL INVESTIGATIOR: R. Lovett}

\section{PERIOD ENGING: $3 / 31 / 95$}

\begin{tabular}{|c|c|c|c|c|c|c|c|c|c|c|c|c|c|c|c|}
\hline DESCRIPTION & $\begin{array}{l}\text { PLANNED } \\
\text { ACTUAL }\end{array}$ & $\begin{array}{c}1 \\
\text { JAN }\end{array}$ & $\stackrel{2}{\text { FEB }}$ & $\stackrel{3}{\mathrm{MARCH}}$ & $\stackrel{4}{4}$ & $\stackrel{5}{\text { MAY }}$ & $\begin{array}{l}6 \\
\text { JUNE }\end{array}$ & $\begin{array}{l}7 \\
\text { JULY }\end{array}$ & $\begin{array}{l}8 \\
\text { AUG }\end{array}$ & $\stackrel{9}{9}$ & $\begin{array}{c}10 \\
\text { OCT }\end{array}$ & $\begin{array}{c}11 \\
\text { NOV }\end{array}$ & $\begin{array}{c}12 \\
\text { DEC }\end{array}$ & $\begin{array}{l}\text { PROJECTED } \\
\text { TOTALS }\end{array}$ & $\begin{array}{l}\text { ACTUAL } \\
\text { TOTALS }\end{array}$ \\
\hline \multicolumn{16}{|l|}{ SALARIES } \\
\hline $\begin{array}{l}\text { R. Lovett } \\
\text { R. Lovett }\end{array}$ & $\begin{array}{l}\text { planned } \\
\text { actual }\end{array}$ & 819 & 819 & 819 & 819 & 819 & 819 & 819 & & & & & & $\$ 5,735$ & so \\
\hline $\begin{array}{l}\text { Supplies } \\
\text { Supplles }\end{array}$ & $\begin{array}{l}\text { planned } \\
\text { actual }\end{array}$ & $\begin{array}{r}166 \\
65\end{array}$ & $\begin{array}{l}166 \\
292\end{array}$ & $\begin{array}{l}166 \\
677\end{array}$ & 166 & 166 & 166 & 166 & & & & & & $\$ 1,163$ & $\$ 1,034$ \\
\hline $\begin{array}{l}\text { Subcontract } \\
\text { Subcontract }\end{array}$ & $\begin{array}{l}\text { planned } \\
\text { actual }\end{array}$ & $\begin{array}{l}37,667 \\
46,000\end{array}$ & $\begin{array}{l}37,667 \\
46,000\end{array}$ & $\begin{array}{l}37,667 \\
46,000\end{array}$ & 26,667 & 26,667 & 26,667 & 17,333 & & & & & & $\$ 210,333$ & $\$ 138,000$ \\
\hline $\begin{array}{l}\text { Travel } \\
\text { Travel }\end{array}$ & $\begin{array}{l}\text { planned } \\
\text { actual }\end{array}$ & 508 & 508 & 508 & 508 & 508 & 508 & 508 & & & & & & $\$ 3,556$ & $\$ 0$ \\
\hline 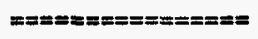 & $x== \pm=====$ & $=\equiv== \pm==2$ & $z==2==0=$ & $=\geq= \pm== \pm=2$ & $x== \pm=== \pm$ & $===== \pm==0$ & $m=x=x== \pm$ & $== \pm=x= \pm=0$ & $==8====0$ & $x= \pm==2 x \pm=$ & $=x=x \sin =$ & $=m=m=\pi x=8$ & $=x=$ & 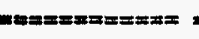 & $m x=2$ \\
\hline $\begin{array}{c}\text { PLANNED TOTALS: } \\
\text { PER MONTH }\end{array}$ & & 39,160 & 39,160 & 39,160 & 28,160 & 28,160 & 28,160 & 18,827 & 0 & 0 & 0 & 0 & 0 & $\$ 220,787$ & \\
\hline $\begin{array}{l}\text { ACTUAL TOTALS: } \\
\text { PER MONTH } \\
\text { = }======== \pm=\end{array}$ & $===== \pm===$ & 46,065 & 46,292 & 46,677 & $== \pm= \pm$ & $y=2=$ & $= \pm= \pm=$ & $2= \pm=$ & $== \pm= \pm=$ & $= \pm$ & 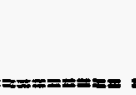 & $==$ & $=2 x=\pi$ & 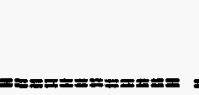 & $\$ 139,034$ \\
\hline $\begin{array}{l}\text { CUMULATIVE } \\
\text { PLANNED TOTALS }\end{array}$ & & 39,160 & 78,320 & 117,480 & 145,640 & 173,801 & 201,961 & 220,787 & 220,787 & 220.787 & 220,787 & 220,787 & 220,787 & $\$ 220,787$ & \\
\hline \multicolumn{16}{|l|}{ CUMULATIVE } \\
\hline $\begin{array}{l}\text { ACTUAL TOTALS } \\
===========\end{array}$ & $===\pi====$ & $\begin{array}{l}46,065 \\
== \pm=x=\end{array}$ & $=$ & $\begin{array}{l}139,034 \\
=\geq== \pm=x=\end{array}$ & $=x=x=x=$ & $=z== \pm=x$ & $x=x====$ & $= \pm= \pm= \pm x=$ & $x=m=x==$ & $==x=x==$ & $=x=x=x$ & $x=m x=x=x$ & $=x=x=x+x=1$ & $x=m= \pm m=\pi x=$ & $\begin{array}{r}\$ 139,034 \\
== \pm=x=m=x=4\end{array}$ \\
\hline OVERBUDGET & & $(\$ 6,905)$ & $(\$ 14,037)$ & $(\$ 21,554)$ & & & & & & & & & & & \\
\hline
\end{tabular}

NOTE: This budget reflects the award of $60 \%$ of the total projects budget (awarded 3/13/95) 


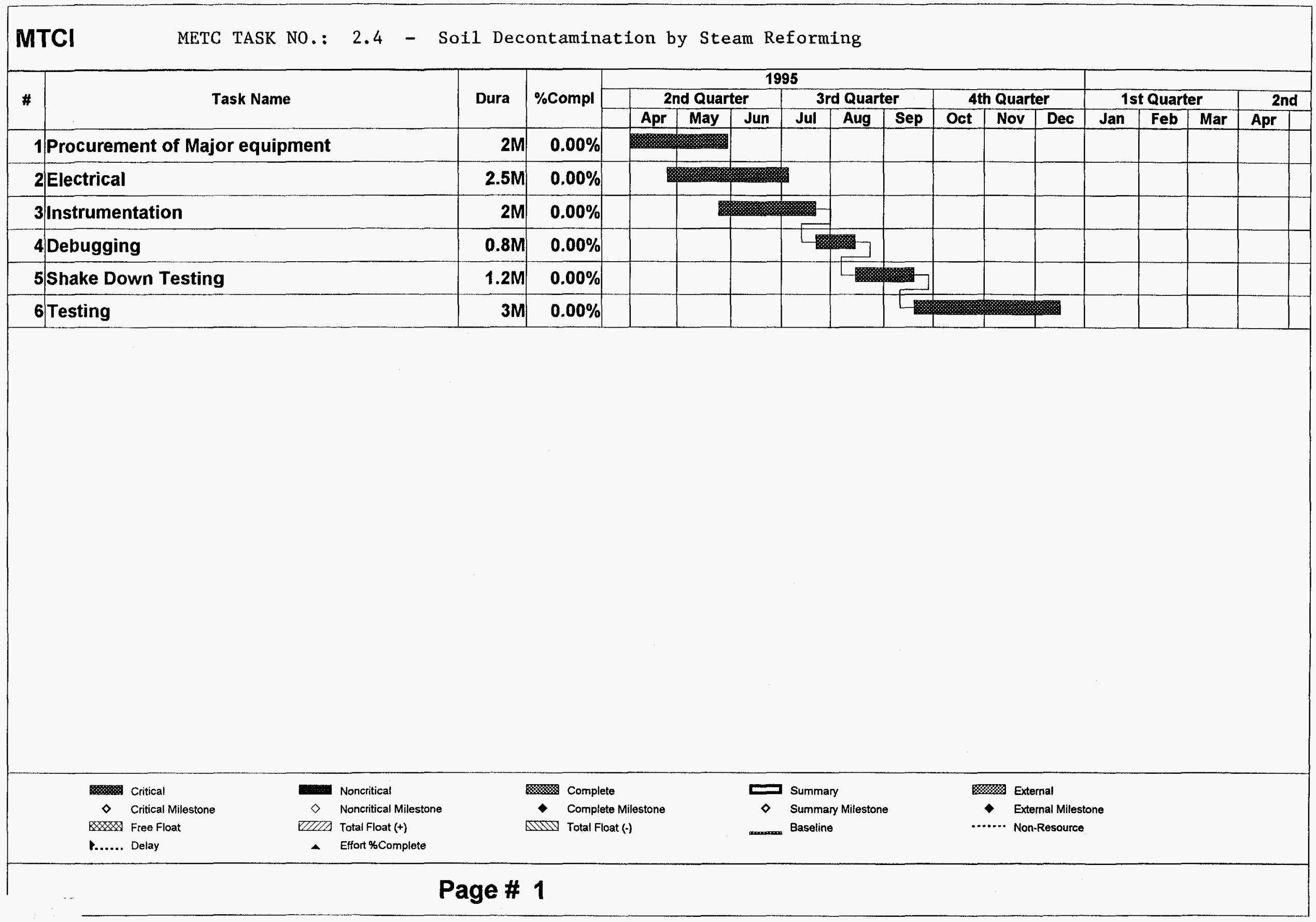




$$
-80-
$$




\section{QUARTERLY TECHNICAL PROGRESS REPORTS}





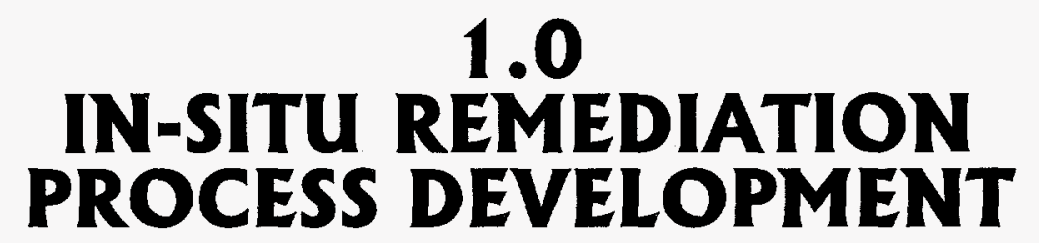





\title{
SITE REMEDIATION TECHNOLOGIES
}

\author{
DRAIN-ENHANCED SOIL \\ FLUSHING (DESF) FOR ORGANIC \\ CONTAMINANTS REMOVAL \\ METC TASK \#: 1.1
}

\author{
Quarterly Report X for Period \\ January 1 through March 31, 1995 \\ Work Performed Under Contract \\ No.:DE-FC21-92MC29467 \\ For \\ U.S. Department of Energy \\ Office of Fossil Energy \\ Morgantown Energy Technology Center \\ Morgantown, West Virginia
}

Principle Investigator:

M. A. Gabr, Ph.D., P.E.

Research Assistants:

John Quaranta

Karl Hewes

Doug Szabo

Department of Civil Engineering

West Virginia University

Morgantown, West Virginia 26505-6101

April 1995 

$\begin{array}{ll}1.0 \text { INTRODUCTION } & 1\end{array}$

$\begin{array}{ll}\text { 2.0 PURPOSE } & 1\end{array}$

$\begin{array}{ll}3.0 \text { BACKGROUND } & 1\end{array}$

4.0 METHODOLOGY 2

5.0 WORK PERFORMED THIS PERIOD 5

6.0 EXPERIMENTAL RESULTS \& DISCUSSIONS 5

$\begin{array}{ll}7.0 \text { CONCLUSIONS } & 6\end{array}$

8.0 WORK PLANNED FOR NEXT PERIOD 6

\section{LIST of FIGURES}

Figure \#1 Smear Cell Apparatus $\quad 4$

Figure \#2 Smear Cell Drawdown Profiles $\quad 7$

$\begin{array}{lll}\text { Figure \#3 Time vs } \mathrm{C} / \mathrm{Co} & 8\end{array}$ 
$-88-$ 


\subsection{INTRODUCTION}

This project researches the use of Prefabricated Vertical Drain (PVD) systems for remediation of contaminated sites with fine grained soils. PVD systems are relatively simple in operation and installation. They require no drilling rig equipment and are expected to significantly reduce remediation costs while at the same time increase the efficiency of the remediation effort.

The use of PVDs in the current state of practice has been in the area of soil improvement. Other than the work performed in the first phase of this project, no research work has been conducted to investigate the feasibility of using PVDs for soil flushing.

\subsection{PURPOSE}

The main objective of this research phase is to investigate major parameters influencing the efficiency of contaminant extraction using PVD systems. Research focused on conducting benchscale tests with soils for simulation of in situ conditions. Specific objectives are as follows:

1. a) Development of the effective diameter for in situ characterization of the PVDs; b) Effect of smear and well resistance on the hydraulic efficiency of the PVDs, and c) Effect of the method of installation on the recovery efficiency of the PVD system.

2. Full development and Beta testing of the PVDs' contaminant transport model developed in Phase I.

3. Field demonstration program and testing, cost analysis, and performance of the recovery process using the PVDs.

\subsection{BACKGROUND}

The PVD system is used to shorten the drainage path of the groundwater flow and therefore promote subsurface liquid movement and expedite the soil flushing process in low permeability soils. Proved technologies exist for the in situ soil flushing for sites with granular soils (hydraulic conductivity approximately $1 \times 10^{-2} \mathrm{~cm} / \mathrm{s}$ ). However in the case of sites where the soil is predominantly clay with corresponding hydraulic conductivity ranging $1 \times 10^{-3}$ to $1 \times 10^{-7} \mathrm{~cm} / \mathrm{s}$, implementation of the traditional soil flushing technology is ineffective and cost prohibitive. 
In the previous phase of this project progress was advanced along the following three fronts:

1. Contaminant and Soil Characterization: A study soil was developed and categorized in accordance with ASTM standards. The testing program included column and batch studies on contaminated soils with the study surfactant being anionic aqueous solution of sodium dodecylsulfate.

2. Injection/Extraction Flushing Concept: Several pilot scale Contaminant Recovery Cells (CRCs) were used to evaluate the flow characteristics of the soils sampled and the concept of using PVDs. Soil samples were prepared in the CRCs and PVDs were installed in rectangular and circular configurations.

3. A predictive model for PVD enhanced soil flushing was developed. The model was developed assuming full saturation and no diffusion or decay. Parameter studies were performed to predict soil flushing rates using a PVD system.

\subsection{METHODOLOGY}

Two different laboratory experiments were setup during this reporting period, 1) Effective Diameter and Smear Effect characterization, and 2) Contaminant Transport Model Verification. The details of these experiments are discussed below.

\section{Preliminary Effective Diameter \& Smear Effects}

The effective diameter and smear effect of the PVDs was evaluated using an apparatus referred to as a Smear Cell, shown in Figure \#1. The Smear Cell was developed to observe the PVD drawdown cone of depression with the study soil under different mandrel installation techniques and vacuums. .Computations were performed to evaluate the hydraulic conductivity of the in situ soil between piezometer and the interface of the PVD. Study soils include Ottawa sand, and mixtures of sand and kaolinite.

Initial experiments embedded the PVD in a $100 \%$ Ottawa sand at a minimum relative density. The PVD was first installed then the sand was rained around the PVD for the full height of the test cell. The approach of first installing the PVD then placing the sand was to obtain a baseline value of the hydraulic conductivity since the PVD was installed with out the influence of the driving mandrel. Experimental results are discussed in Section 6.0. 


\section{Contaminant Transport Model}

Use of the Contaminant Recovery Cells (CRC) continued during this reporting period. Assessment of the injection and extraction efficiency was performed. The experiment equipment and procedures were modified. Equipment retrofits consisted of providing vacuum and pressure gages and volumetric control valves for modulating the inflow and outflow fluids.

The CRC apparatus has the following dimensions: $(0.67 \mathrm{~m} \times 0.67 \mathrm{~m} \times 1.0 \mathrm{~m}$ : length/thickness/depth of soil). The CRC features a central section which is filled with the study soil and an upstream reservoir to supply a base inflow into the soil while the downstream reservoir collects the base outflow. The reservoirs are used to pre-saturate the soil and to apply a constant base flow during the contaminant recovery tests.

The PVD configurations investigated were circular and triangular. For the circular arrangement, five extraction PVDs are located at the perimeter and a sixth PVD is positioned at the circle's center, functioning as the injection source. The triangular PVD configuration was laid out based on information from the NILEX Corporation, the industry partner. This arrangement locates the PVDs in off-set rows, alternating extraction and injection.

Experimentation used a 1,000 ppm solution of sodium chloride $(\mathrm{NaCl})$ injected into the center (for circular layout) or offset PVD (for triangular layout) and a uniform vacuum was applied for fluid extraction. The extracted fluids were analyzed for chloride ion concentrations and plots showing concentration changes versus time were prepared. 


$$
s=
$$

o
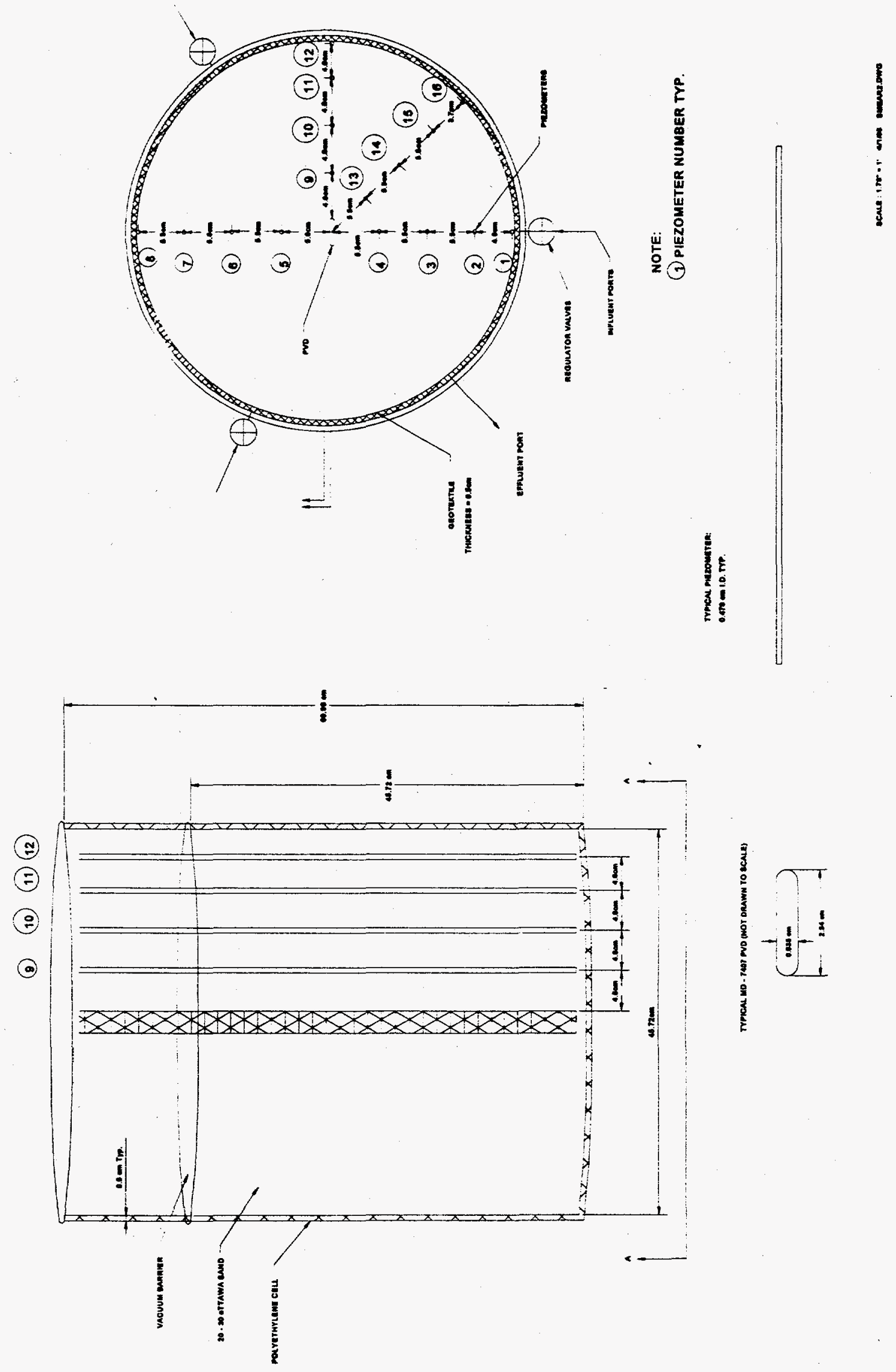

Figure \#1 - Smear Cell Apparatus 


\subsection{WORK PERFORMED THIS PERIOD}

Work performed during this reporting period included the following tasks:

1. Experimentation on the Effective Diameter and Smear Effects.

2. Experimentation on the influence of PVD layout on chloride capture efficiency.

3. Draft development of the Field Demonstration Plan.

4. Preparation of the outline for draft development of the Economic Evaluation.

Preliminary Effective Diameter \& Smear Effects: Initial experiments embedded the PVD in a $100 \%$ Ottawa sand at a minimum relative density. Experiments performed were directed at developing baseline conditions using sand as the study soil. PVDs were installed and vacuums applied to evaluate the cone of depression developed in the study soil at various vacuums.

Contaminant Transport Model: Experimentation continued with the commissioning of the equipment modifications and revised testing procedures. Sodium chloride experiments in CRC with sand and a $80 \%$ sand and $20 \%$ kaolinite soil mix were performed to evaluate circular and triangular PVD spacing configurations. Experimental results and discussions are presented in the next section.

Field Demonstration Plan: A draft scope of work document was begun. This document will identify the requirements necessary to perform a field demonstration.

Economic Evaluation: Preparation of an outline for development of the Economic Evaluation was begun.

\subsection{EXPERIMENTAL RESULTS \& DISCUSSIONS}

Preliminary Effective Diameter \& Smear Effects: Sample results of the cone of depression drawdowns developed for a $100 \%$ sand are shown in Figure \#2. Refer to Figure \#1 for piezometer locations and distances. Observations of Figure \#2 show a uniform head developed by the PVD in the study soil. The significance of this observation is that for this study soil there is a uniform distribution of the vacuum head potential developed around the perimeter of the PVD. The implications of this effect is that the PVD appears to function similar to a circular well which develops a similar cone of depression profile. This information is useful for selecting the installation spacings of the PVDs. 
Contaminant Transport Model: Figure \#3 shows concentration changes for the chloride ion concentration increase with time and all PVDs reach a $100 \%$ capture of the sodium chloride tracer within 55 minutes. This finding indicates a $100 \%$ efficiency of the PVDs. These results are a marked improvement over the data obtained during the last reporting period where only a $70-80 \%$ efficiency was attained. This test was conducted with only minimal difference of $0.87 \mathrm{~L}$ in the fluid mass balance, the injected volume was $55.16 \mathrm{~L}$ and the extracted volume was $56.03 \mathrm{~L}$. The efficiency increase is attributed to the exacting control capabilities produced by the equipment and experimental procedural changes implemented during this reporting period.

\subsection{CONCLUSIONS}

The results of the experiments conducted using the CRC equipment for verification of the transport model indicate that with flow and vacuum controls on each of the PVDs, extraction of the injected tracer is possible with a $100 \%$ efficiency. The experiments performed on the smear cells to observe the cone of depression provide baseline values from which comparison of hydraulic conductivity changes will be made.

\subsection{WORK PLANNED FOR NEXT PERIOD}

Tasks to be performed for the next reporting period include using higher kaolinite mix proportions in both the CRC and Smear Cell apparatus. Base line values using sand will be correlated with the new results. Completion of the outline for the Economic Evaluation will be performed and a draft Site Demonstration proposal may be completed. 
SMEAR CELL \#1 TRIAL \#3 ON 20 - 30 OTTAWA SAND

VACUUM PRESSURE AT 40 in. $\mathrm{H}_{2} \mathrm{O}$

Piezometers 1 - 4

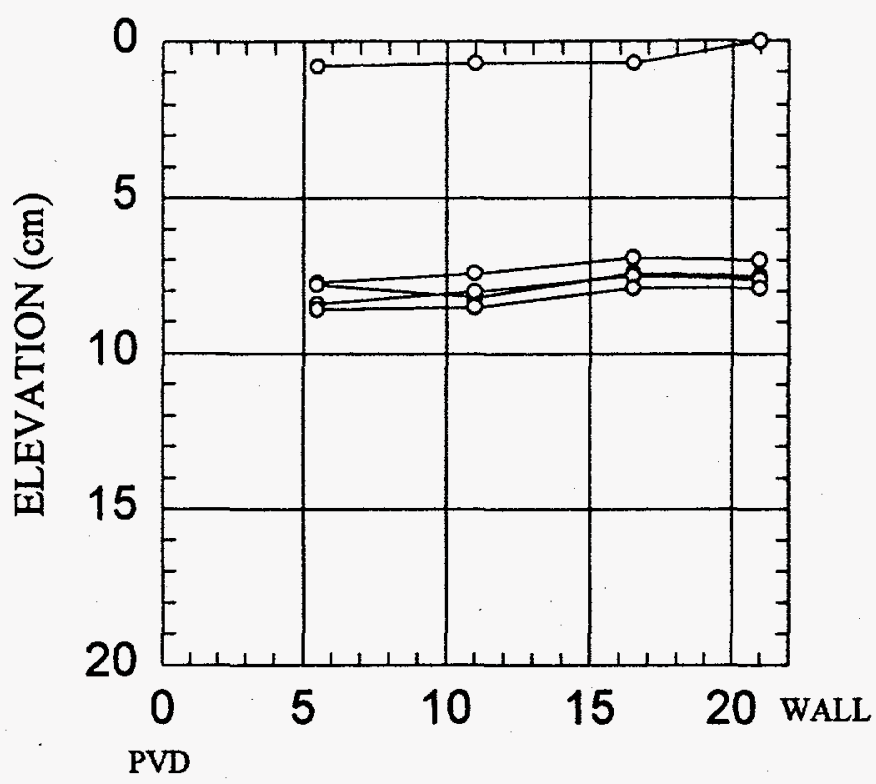

DISTANCE $(\mathrm{cm})$

Piezometers 9 - 12

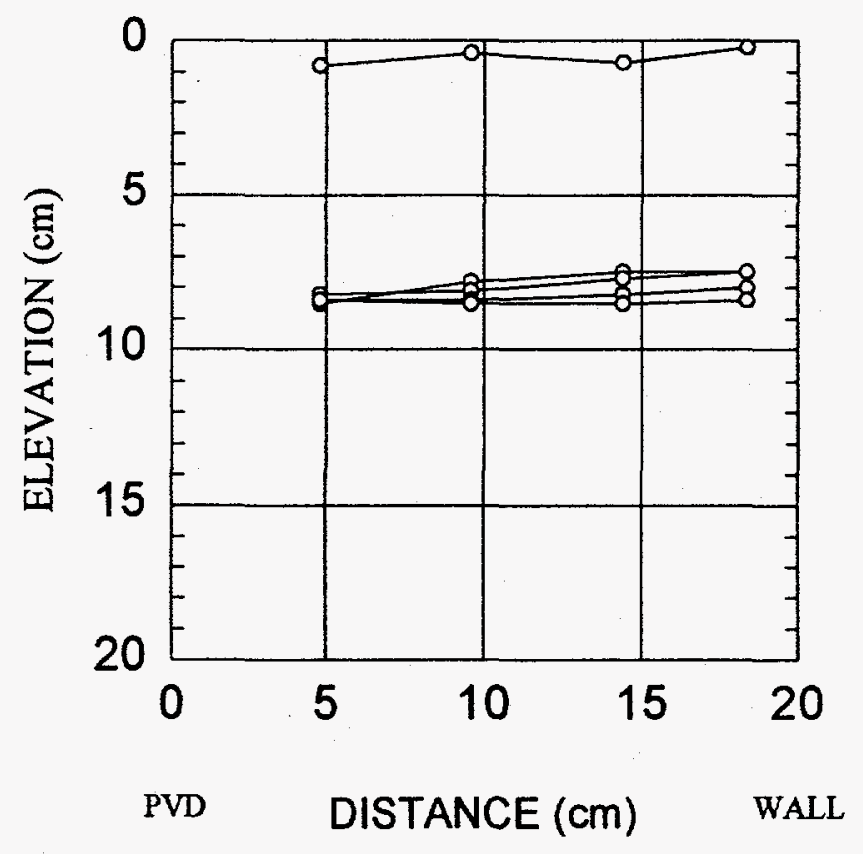

Piezometers 5 - 8

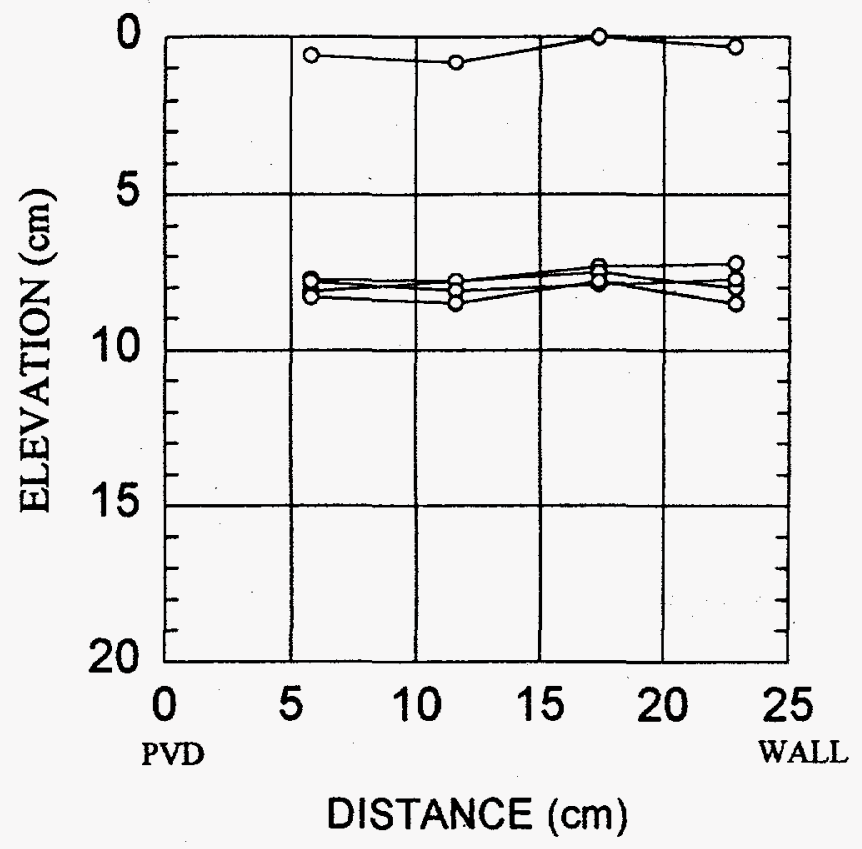

Piezometers 13 - 16

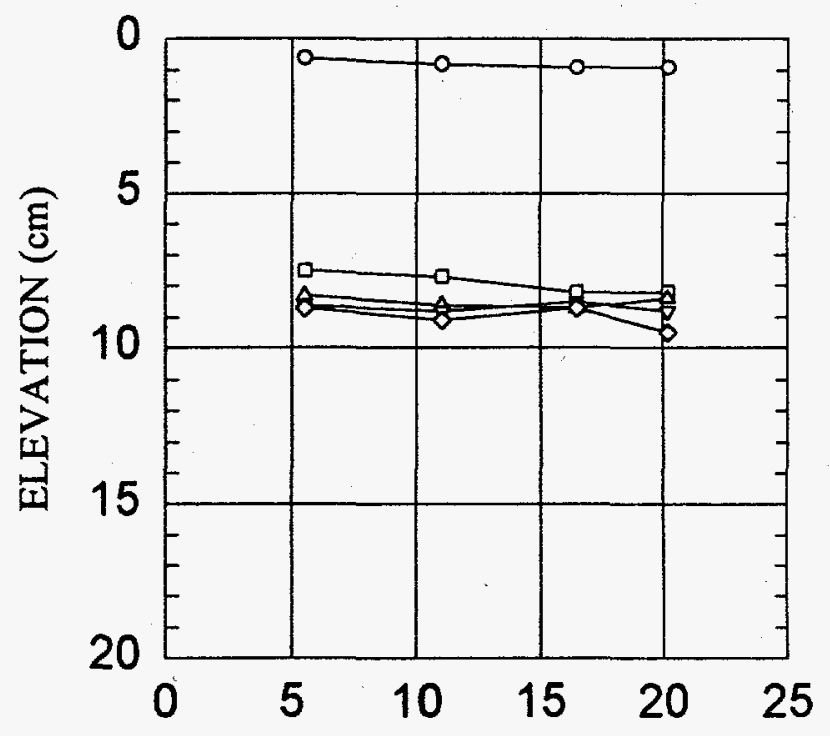

PVD DISTANCE (cm)

$3 / 22 / 95$
WALL

EXP1-T3.SPW

Figure \#2 - Smear Cell Drawdown Profiles 


\section{Time vs $\mathrm{C} / \mathrm{Co}$}

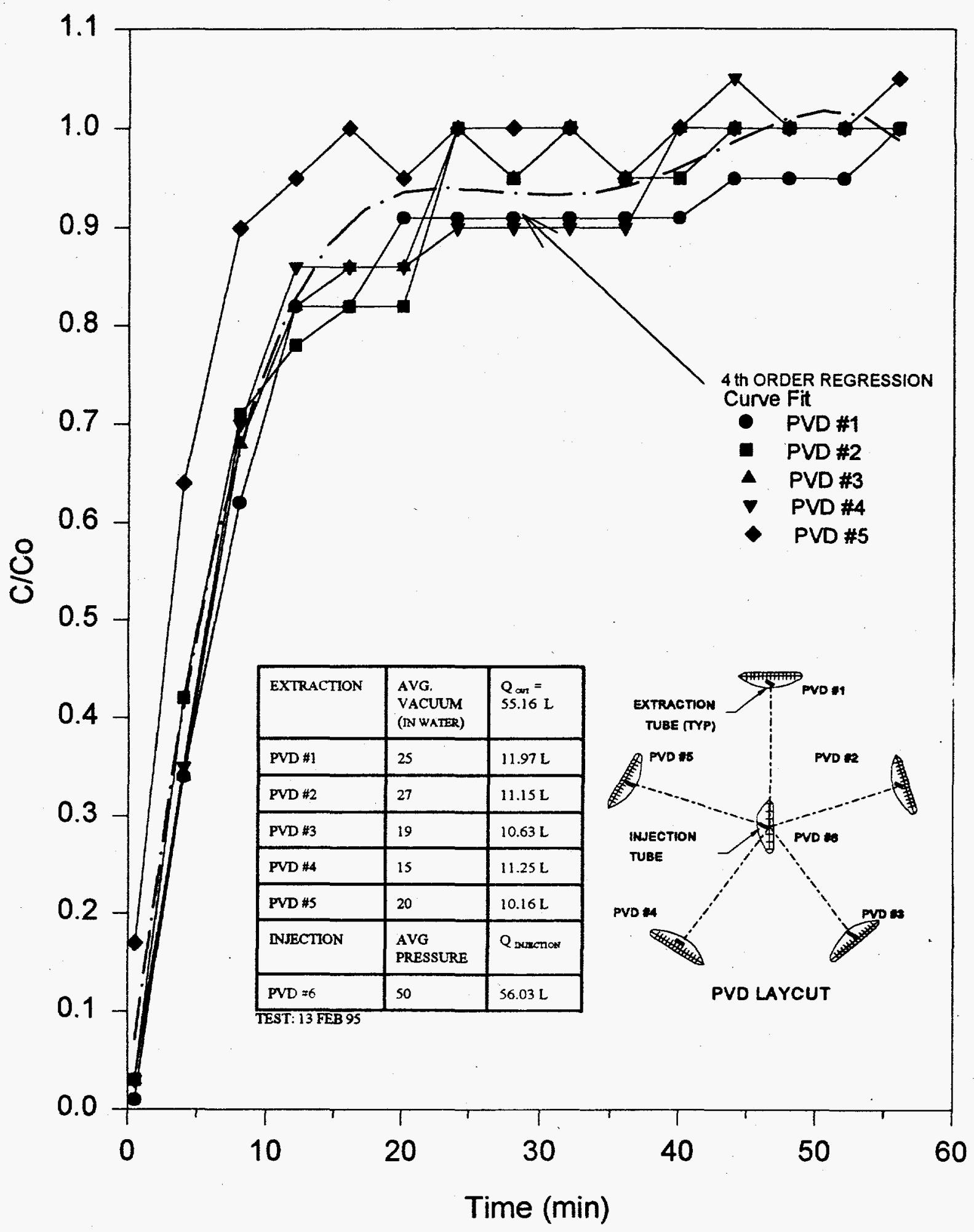

Figure \#3 - Time vs $\mathrm{C} / \mathrm{Co}$ 
SITE RFMEDIATION TECENOLOGIES

Quarterly Technical Progress Report

for Period January 1 through March 31, 1995

Work Performed Under

Contract No.: DE-FC21-92M29467

\author{
For \\ U.S. Department of Energy \\ office of Fossil Energy \\ Morgantown Energy Technology center \\ P.O.Box 880, Collins Eerry Road \\ Morgantown, West Virginia
}

\title{
By
}

William A. Sack, Department of Civil Engineering Patrick E. Carriere, Department of Civil Engineering Sowmya Raman, Department of Civil Engineering.

Michael P. Davis, Department of Civil Engineering Andrew K. Shiemke, Department of Biochemistry

West Virginia University

Morgantown, West Virginia 26506

April, 1995 



\section{Abstract}

In situ bioremediation offers a number of advantages over other processes for destruction of organics in groundwater. Advantages include the potential for complete or near complete destruction of contaminants in place, avoidance of transfer of pollutants to another medium, less risk of health hazards due to human exposure and cost-effectiveness in many cases. This research seeks to exploit the natural symbiotic relationship between methanogenic and methanotropic microorganisms. The methanogens are able to carry out the anaerobic reductive dehalogenation (RD) of highly chorinated solvents producing methane. The methanotrophs, in turn, utilize the end products of the methanogens, including methane, to aerobically degrade the residual compounds to environmentally acceptable end products. Both groups of organisms work cometabolically and require a primary substrate.

The project is divided into two main tasks and a number of subtasks. Under task 1. controlled testing will be performed in columns to find optimum conditions for the complete mineralization of trichloroethylene (TCE) to innocuous end products. Columns will be set up to examine both sequential and simultaneous mineralization. In the sequential columns, RD will be accomplished first with conditions that favor methanogens followed by aerobic conditions that favor methanotrophs. In the simultaneous column, an attempt will made to set up conditions which promote anaerobic microzones within the columns so that RD and aerobic oxidation take place almost continuously alone the column. It is planned to use hydrogen peroxide as an electron acceptor for the methanotrophs.

In task 2, delivery of amendments (such as the primary substrate and electron acceptor) to low permeability soils using prefabricated wick drains (PVD's) will be evaluated using a box lysimieter. Use of wick drains for delivery of amendments and possible ground water recirculation is a unique application of this technology and offers significant improvement over existing methods which require a large number of wells in "tight" soils. 
In situ bioremediation offers a number of advantages over other processes for destruction of organics in groundwater. Advantages include the potential for complete or near complete destruction of contaminants in place, avoidance of transfer of the pollutants to another medium, less risk of health hazards due to human exposure and cost-effectiveness in many cases. The objective of this research is to evaluate and optimize the ability of methanotrophic, methanogenic, and other selected bacteria for cost-effective biotransformation of a mixture of chlorinated solvents as are often found at DOE sites. A five phase workplan is utilized which involves the systematic manipulation of environmental conditions to enhance the rate and extent of biodegradation of the candidate voc's. It is planned to take advantage of the natural symbiotic relationship between the methanogenic and methanotrophic bacteria so as to promote sequential anaerobic/aerobic mineralization of the chlorinated solvents.

The anaerobic column was operated this quarter under a variety of conditions. Parameters investigated included TCE concentration, potential nitrogen limitation, methanol feed level and response to a short-term TCE shock. It was found that an increase in the ammonia nitrogen level in the feed (from 8 to 55 $\mathrm{mg} / \mathrm{L}$ ) significantly improved TCE removal (from 10 to 58 \%) Hence, it seems apparent that the ammonia nitrogen level in the feed was limiting. TCE feed levels of 1.6 and $5.0 \mathrm{mg} / \mathrm{I}$ were evaluated with respect to column performance. It was found that the removal of TCE improved from 58 to 67 as the feed concentration was increased from 1.6 to $5.0 \mathrm{mg} / \mathrm{L}$. The mass removal rate of TCE increased from $5.5 \mathrm{ug} / \mathrm{h}$ at $1.6 \mathrm{mg} / \mathrm{L}$ to $14.5 \mathrm{ug} / \mathrm{h}$ at the $5.0 \mathrm{mg} / \mathrm{L} \mathrm{TCE}$ concentration. However, the concentration of daughter products was about the same at both feed TCE levels. As expected, the feed concentration of the primary substrate (methanol) had a significant effect on TCE removal. As methanol was increased from 185 to $751 \mathrm{mg} / \mathrm{L}$, TCE removal improved from 49 to 67 \% respectively. A slug of TCE (about $19.0 \mathrm{mg} / \mathrm{L}$ ) inadvertently entered the system for about three days. It was found that the methanogens were able to handle the shock load and still achieve an overall removal of about 49 with no apparent toxic effects.

The aerobic column was operated this quarter under a variety of conditions. Parameters investigated included the concentration of primary substrate (methanol) and an alternative electron acceptor (hydrogen peroxide). A shock load of TCE was accidentally fed to the column for a short period allowing an evaluation of system response to a slug load. It was found that the overall removal rate and percent TCE removal at the top port were $9 \mathrm{ug} / \mathrm{h}$ and 208 respectively. It is anticipated that $T C E$ removal will continue to improve as the methanol concentration is increased. The Do concentration increased from 2.69 to $7.35 \mathrm{mg} / \mathrm{L}$ after addition of hydrogen peroxide. A shock load of TCE was inadvertently fed to the column for a short period allowing an evaluation of system response to a slug load. At the top port, the concentration increased to $12.9 \mathrm{mg} / \mathrm{L}$ for the first six hours and then suddenly decreased to $8490 \mathrm{ppb}$ in the next three hours. A similar pattern of an increase followed by a decrease in concentration was observed in the next twelve hours. The maximum concentration recorded was $10.8 \mathrm{ug} / \mathrm{L}$ and the concentration came down to $0.6 \mathrm{mg} / \mathrm{L}$. At the middle and bottom ports, a steady decrease in TCE concentration was observed as expected.

Work was also carried out on column design for the simultaneous system experiments and on the protocol to locate the anaerobic and aerobic zones. 


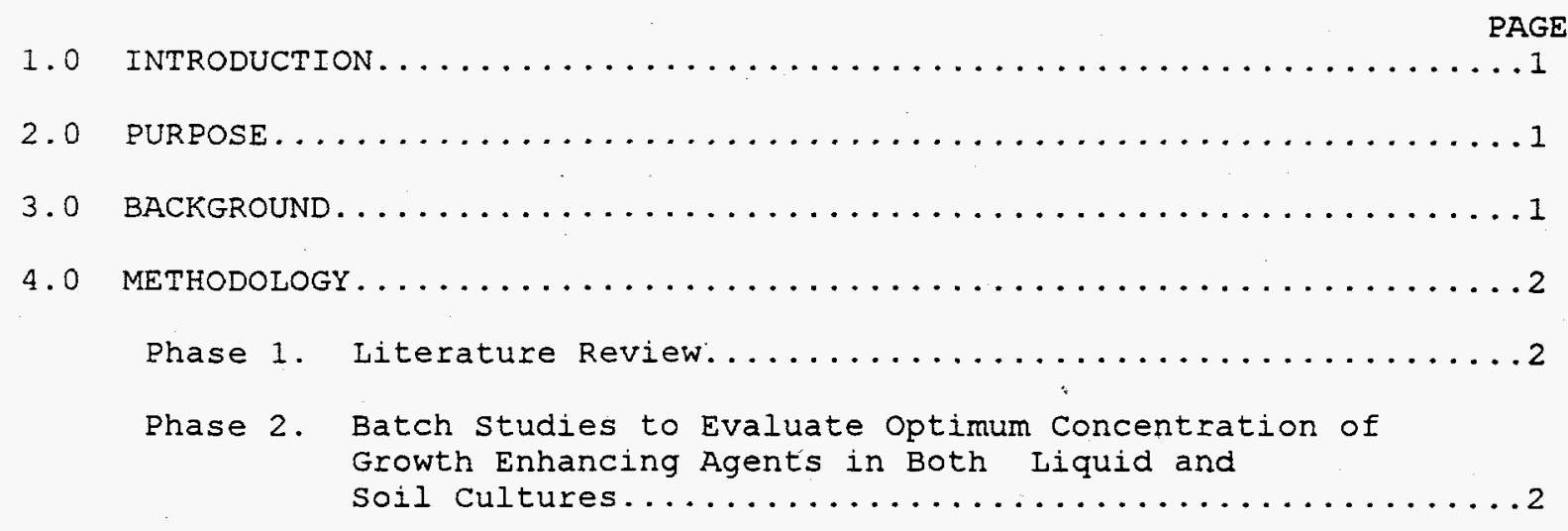

Phase 3. Column Studies to Evaluate the Rate and Extent of Degradation of Candidate vocs..................

Phase 4. Comparison of TCE Biotransformation by Particulate and

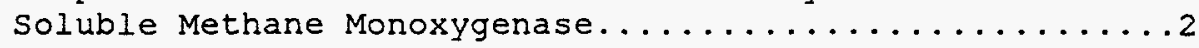

Phase 5. Investigation of the Utilization of the symbiotic Relationship Between Methanogenic and Methanotrophic Bacteria for VoC Degradation Without Addition of

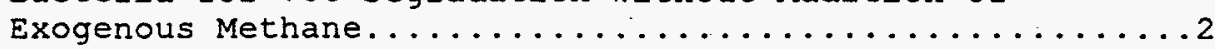

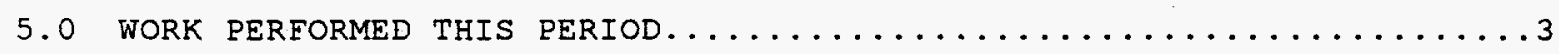

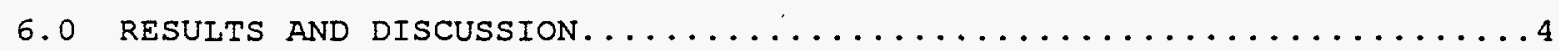

6.1 Anaerobic studies..........................4

6.1 .1 Effect of Nitrogen......................

6.1 .2 Effect of TCE Concentration..................

6.1 .3 Effect of Methanol.....................

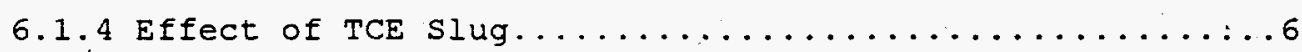

6.2 Aerobic studies...........................

6.2 .1 Aerobic column studies...................8

6.2 .2 Effect of Methanol and Hydrogen Peroxide.........11

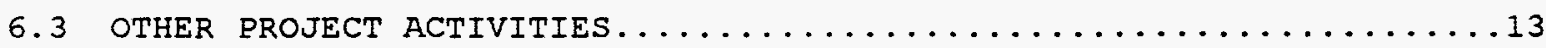

6.3.1 Subtask 1.1:Optimization of Sequential Mineralization..13

6.3.2 Subtask 1.2: Design and Construction of the Simultaneous Mineralization column...........13

6.3.3 Subtask 1.3: Development of Protocol to Locate Anaerobic and Aerobic zones.........13

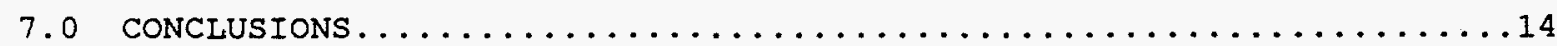




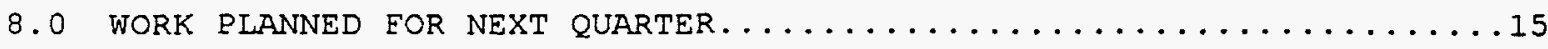

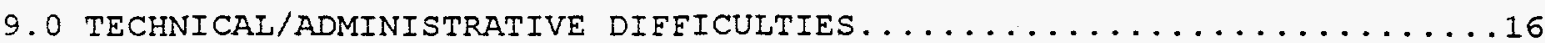

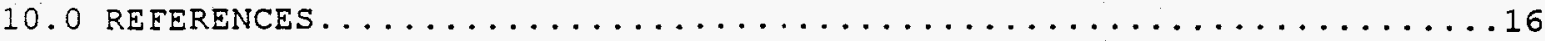

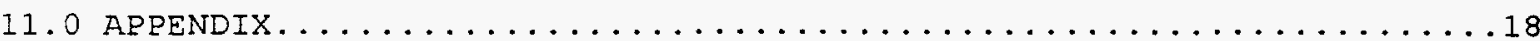

vi 
LIST OE FIGURES

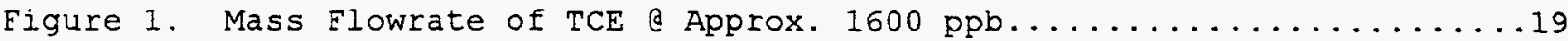

Eigure 2. Mass Flowrate of TCE Removed in Top Port with

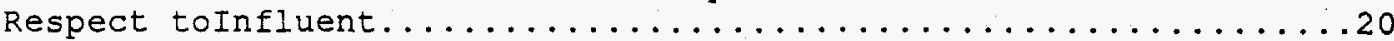

Eigure 3. Percent Removal in Top Port with

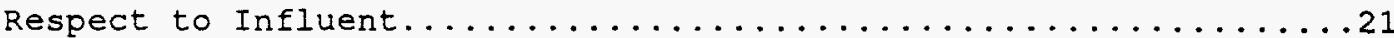

Figure 4. Mass Flowrate of 1, 1-DCE @ Approx. 1600 ppb.............22

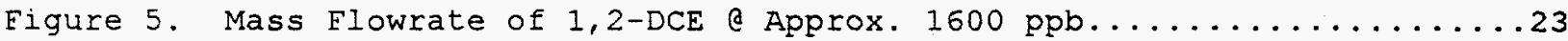

Figure 6. Mass Flowrate of TCE \& Approx. $5000 \mathrm{ppb} \ldots \ldots \ldots \ldots \ldots \ldots \ldots \ldots$

Figure 7. Mass Flowrate of TCE Removed in Top Port with

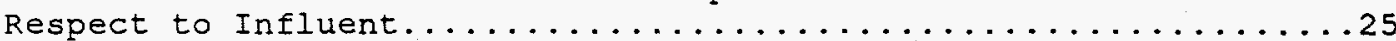

Eigure 8. Percent Removal in Top Port

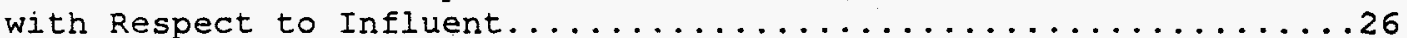

Figure 9. Mass Elowrate of 1,1-DCE \& Approx. 5000 ppb................

Figure 10. Mass Flowrate of 1,2-DCE \& Approx. 5000 ppb.............28

Figure 11. Concentration of TCE during Shock Period................29

Figure 12. Concentration in Bottom Port during shock Period...........30

Figure 13. Concentration in Top Port during shock Period................

Figure 14. Top, Middle, and Bottom Port Concentrations..............32

Eigure 15. Overall Percent Removal of TCE.......................

Figure 16. Change in Concentration of TCE at Top, Middle,

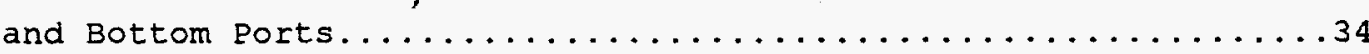

Figure 17. Top, Middle, and Bottom Port Concentrations...............35

Figure 18 Overall TCE Removal Rate $(\mathrm{ug} / \mathrm{hr}) \ldots \ldots \ldots \ldots \ldots \ldots \ldots \ldots \ldots \ldots$

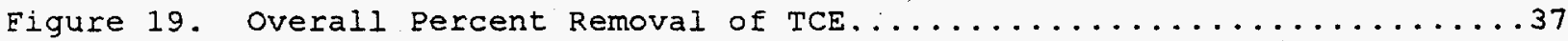

Figure 20. Changes in Aerobic Column Conditions with Time.............38 
LIST OF TABLES

Table 1. Concentration of TCE, Primary Substates and Ammonia Feed

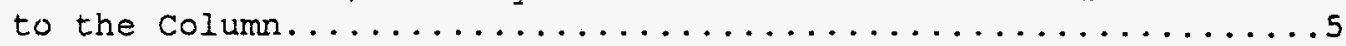

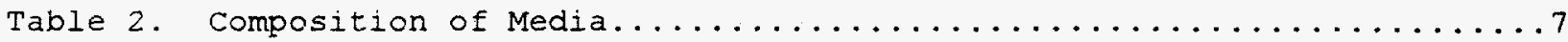

Table 3. Summary of Performance Data - Anaerobic Column..............8

Table 4. Aerobic Column Conditions $(12 / 16 / 94-4 / 6 / 94) \ldots \ldots \ldots$

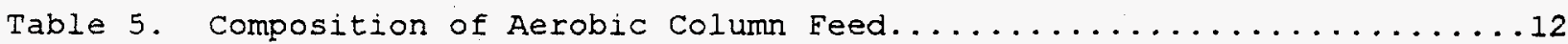

Table 6: Hydrogen Peroxide and Associated Methanol Concentrations.......13 


\subsection{INTRODUCTION}

A variety of toxic organic contaminants are found at DOE sites including fuel hydrocarbons, polychlorinated biphenyls. (PCB's) and volatile organic solvents such as trichloroethylene (TCE), perchloroethylene, and carbon tetrachloride. These compounds may occur as single contaminants, but are often found in conjunction with heavy metals or in mixed wastes containing radioactive components.

In-situ bioremediation has a number of advantages for destruction of organic contaminants in groundwater. Other processes such as sorption and volatilization do not destroy contaminants, but rather just concentrate them or transfer them to another medium. Abiotic (chemical) transformation is not normally costeffective in groundwaters and may even result in production of more toxic chemical species.

Clean-up methods often involve soil flushing to mobilize the contaminants for transport to the surface for treatment. However, because many organic contaminants sorb to soils, they are not readily leached from the soils often leaving toxic residuals in place even after flushing. Eurthermore, bringing the contaminants to the surface increases the risk of health hazards due to human exposure. There is increasing recognition that bacteria are present and active in the subsurface and that in situ biotransformation offers a potentialiy more effective and economical method of contaminant destruction.

\subsection{PURPOSE}

The purpose of the research is to evaluate and optimize the ability of methanotrophic, methanogenic, and other selected bacteria for cost-effective biotransformation of TCE and other volatile organic compounds (VoC's) found at DOE sites. The approach outlined involves the systematic manipulation of environmental conditions in the subsurface for the purpose of enhancing the rate and extent of biodegradation of candidate (VOC's). This approach takes advantage of the ubiquity of methanotrophic and methanogenic bacteria and introduction of non-native organisms should not be necessary. Also, only relatively benign enhancing compounds will be added in non-toxic concentrations. It is envisioned to take advantage of the natural symbiotic relationship between the methanogenic and methanotrophic bacteria so as to promote sequential anaerobic/aerobic mineralization of the chlorinated solvent contaminants.

\subsection{BACKGROUND}

A number of exciting developments are occurring in the field of environmental biotechnology (engineering applications of microbial ecology). For example, while trace concentrations of some organic contaminants cannot support microbial growth as the sole electron donor, they can still be biotransformed by engineering the system so that the microbial population obtains the majority of its energy and carbon from a different compound that serves as the primary substrate. This is sometimes referred to as secondary utilization. There are also many organic contaminants that are biotransformed in the environment for which no microorganisms have been found which are able to use them as sole carbon source. This is a special case of secondary metabolism often termed cometabolism. Cometabolism has been defined (Dalton, 1982) as the "transformation of a nongrowth substrate in the obligate presence of a growth substrate or another 
transformable compound". As an example, halogenated methanes, ethanes, and ethylenes are poor growth substrates for bacterial growth but may be degraded by methanotrophs growing aerobically on methane (Henson et al., 1988).

\subsection{METHODOLOGY}

The principal focus of the investigation is to develop methods which will enhance bacterial metabolism of organic contaminants in sub-surface environments in order to increase the rate and extent of biodegradation. Our original proposal was organized into five phases, as follows:

Phase 1: Literature Review.

Phase 2: Batch Studies to Evaluate Optimum Concentration of Growth Enhancing Agents in Both Liquid and Soil Cultures.

Phase 3: Column Studies to Evaluate the Rate and Extent of Degradation of Candidate Voc's.

Phase 4: Comparison of TCE Biotransformation by Particulate and Soluble Methane Monoxygenase.

Phase 5: Investigation of the Utilization of the Symbiotic Relationship Between Methanogenic and Methanotrophic Bacteria for VOC Degradation Without Addition of Exogenous Methane.

A comprehensive literature review of biodegradation of chlorinated solvents was completed and submitted as part of the second quarterly report. As a result of this review we realized the potential for developing the relationship between the methanotrophs (aerobic) and the methanogens (anaerobic) for mineralization of both highly chlorinated and less chlorinated compounds. Emphasis was given to this approach in subsequent phases of the workplan.

The methanotrophs have an obligate requirement for methane, which is complemented by the methane production of methanogenic organisms. Furthermore, the methanogens ability to dehalogenate more oxidized (more halogenated) pollutants, generating vinyl chloride, is complemented by the ability of the methanotrophs to mineralize vinyl chloride and other small mono-chlorinated hydrocarbons. The rate limiting step of mineralization under anaerobic conditions is the dehalogenation of vinyl chloride. Thus, it might be advantageous to induce methanotrophic growth at the point where all (or most) of the more chlorinated compounds have been dehalogenated to vinyl chloride. The number of chlorines dramatically effects the rate of anaerobic degradation: the more chlorines the faster the rate of degradation (Sims et al., 1990). A higher number of halogen substituents results in a more oxidized compound making it more susceptible to biological reduction.

Although methanogenic bacteria will not grow in the presence of oxygen, the reductive dehalogenation reaction is somewhat oxygen tolerant. The rate of TCE degradation is reduced under micro-aerophilic conditions, but not completely blocked (Freedman and Gossett, 1989). Under these conditions a suitable source of reducing equivalents must be provided (eg. methanol, hydrogen, acetate, and formate). It is interesting to note in this regard that kastner (1991) reported that an aerobic enrichment culture's ability to dechlorinate cis-1,2dichloroethylene was shown to be dependent on a cyclic transition from aerobic to anaerobic conditions and limited oxygen supply. It may also be possible to increase biodegradation rates by alternating methanogenic and methanotrophic growth conditions, thus limiting the accumulation of potentially toxic 
byproducts, as well as optimizing the alternating production of methane rich and oxygen rich conditions.

\section{O WORK PERFORMED THIS PERIOD}

This quarter, the anaerobic and aerobic columns continued to be operated separately in an upflow mode. A variety of parameters were evaluated for each columns prior to joining them in sequential and simultaneous systems. For the anaerobic columns, parameters evaluated included influence of nitrogen, methanol, TCE concentration and results of a shock load. For the aerobic columns, evaluation was carried out of the influence of methanol level and an alternative electron acceptor (hydrogen peroxide). A shock load was also applied (accidently) to the aerobic column. Work was also carried out on column design for the simultaneous system experiments and on the protocol to locate the anaerobic and aerobic zones.

A brief summary of progress on the tasks is presented below.

\subsection{Optimization of Sequential Mineralization--30 8 Complete}

This task was perfomed this quarter in the individual columns by investigation of the influence of a variety of variables on performance.

\subsection{Design and Construction of Simultaneous Mineralization Column-50\% Complete}

This quarter, the column was designed and pumps, column and parts ordered when funds became available in March.

\subsection{Development and Testing of Protocol to Locate zones--100 8 Complete}

As discussed in the Results section, work on this task this quarter led to a decision that the odds of success without a major amount of work on the issue were not very good. It was felt that further work on this task at this time could result in significant delay of the project. It was therefore decided to terminate work on this task unless further literature review indicates a higher probability of success.

\subsection{Optimization of Simultaneous Mineralization--0 complete}

Work on this task will begin next quarter when the column is received and constructed.

1.5 Assessment of Potential Bioremediation of High Concentrations of caH Compounds

$--5 \div$ Complete

This task was briefly worked on this quarter when accidental shock loads of TCE entered both the anaerobic and aerobic columns.

\subsection{Design and Construction of Lysimeters Equipped with PVD's--0 \& Complete}

\subsection{Amendments Delivery and Potential Clogging--0 \& Complete}

\subsection{Preparation and Submission of quarterly and Final Reports--25 Complete}


Assuming equal weight for each of the 8 project tasks noted above, it is estimated that the overall project is 26.25 complete.

\subsection{RESULTS AND DISCUSSION}

\subsection{Anaerobic Studies}

Evaluation of TCE removal in a separate anaerobic column was continued this quarter. The column was operated in a continuous upflow mode under a variety of conditions. Different parameters such as the concentration of influent TCE, nitrogen and methanol were investigated. In addition, a shock load of TCE was accidentally fed to the column. for three days which provided valuable data on the ability of the system to accept shock loads.

As noted in earlier reports, anaerobic decomposition of chlorinated solvents is cometabolic and a primary substrate is needed to accomplish the desired reductive dehalogenation (RD) of the solvents. During $R D$, the halogenated compound becomes an electron acceptor and chlorine atoms are sequentially replaced by hydrogen atoms. Reduction of TCE proceeds via the formation of one of three isomers of dichloroethylene (trans-, cis-, or 1,1-DCE) or vinyl chloride.

Methanol and acetic acid are being used as the primary substrates to accomplish RD of TCE. The concentrations of TCE, the primary substrates and ammonium chloride fed to the column during the quarter are shown in Table 1. The composition of the basal salts media utilized (as well as the TCE and primary substrates) is presented in Table 2. It should be noted that the basal salts added remain unchanged during the quarter (except for ammonia nitrogen) while the TCE, primary substrate, and ammonia nitrogen were modified as shown in Table 1. The columns was operated at a hydraulic detention time of 48 hours with a feed flow rate of approximately $5 \mathrm{ml} /$ hour. The $\mathrm{pH}$ varied from 6.7 to 7.5 during the quarter.

\subsubsection{Effect of Nitrogen}

The TCE concentration was lowered from $5.0 \mathrm{ppm}$ to $1.6 \mathrm{ppm}$ on $1 / 14$ in order to evaluate performance at a lower TCE level. However there was also a desire to investigate whether nitrogen might be a limiting factor. As shown in Table 1 , the influent ammonia nitrogen level had been set at about $8 \mathrm{mg} / \mathrm{L}$ based on an early estimate of biomass yield in the anaerobic column. In order to ensure that excess nitrogen was available to the biomass, the influent ammonia nitrogen concentration was increased to $55.0 \mathrm{mg} / \mathrm{L}$ on $1 / 24$.

The TCE mass flow rate (concentration $X$ flow) in the influent and at the bottom, middle and top ports is shown in Figure 1 in ug/h. Figures 2 and 3 show the mass rate of removal and percent removal respectively of TCE across the column (influent to top port). It should be noted that the apparent negative removal from $1 / 12$ to about $1 / 20$ was due to the reduction in TCE concentration from $5.0 \mathrm{ppm}$ to $1.6 \mathrm{ppm}$. Examination of Figure 3 shows that increasing the nitrogen concentration was beneficial as TCE removal improved from around 10\% to about 58\%. The mass removal rate of TCE correspondingly increased from 1.2 to $5.5 \mathrm{ug} / \mathrm{h}$.

The mass flow rate of the daughter products, 1,1-DCE and 1,2-DCE are shown in Figures 4 and 5 respectively. It may be noted that the rate of formation of 1,1-DCE decreased after the nitrogen concentration was increased but it increased for the 1,2-DCE. Before increasing the ammonia nitrogen level, the mass rate of 
Table 1. Concentration of TCE, primary substrates and ammonia feed to the column.

\begin{tabular}{|l|l|l|l|l|l|}
\hline Dates & $\begin{array}{l}\text { TCE conc } \\
(\mathrm{mg} / \mathrm{L})(\mathrm{I})\end{array}$ & $\begin{array}{l}\text { TCE loading } \\
(\mathrm{mg} / \mathrm{d} \mathrm{L})\end{array}$ & $\begin{array}{l}\text { Methanol } \\
\text { Conc. } \\
(\mathrm{mg} / \mathrm{L})\end{array}$ & $\begin{array}{l}\text { Acetic } \\
\text { acid } \\
\text { conc. } \\
(\mathrm{mg} / \mathrm{L})\end{array}$ & $\begin{array}{l}\text { Ammonia } \\
\text { Conc } \\
(\mathrm{mg} / \mathrm{L})\end{array}$ \\
\hline $1 / 14-1 / 23$ & 1.6 & 0.326 & 751 & 183 & 7.7 \\
\hline $1 / 24-2 / 20$ & 1.6 & 0.326 & 751 & 183 & 55.0 \\
\hline $2 / 21-2 / 23$ & 19.0 & 3.813 & 751 & 183 & 55.0 \\
\hline $2 / 24-3 / 6$ & 1.6 & 0.326 & 751 & 183 & 55.0 \\
\hline $3 / 7-3 / 14$ & 5.0 & 1.02 & 751 & 183 & 55.0 \\
\hline $3 / 14-3 / 31$ & 5.0 & 1.02 & 185.4 & 183 & 55.0 \\
\hline
\end{tabular}

(1) The TCE values shown are target values, while the actual concentration fed to the column varies from syringe to syringe.

1,1-DCE and 1,2-DCE leaving the columns averaged $0.11 \mathrm{ug} / \mathrm{h}$ and $0.22 \mathrm{ug} / \mathrm{h}$, respectively, corresponding to a 1,1-DCE to $1,2-D C E$ ratio of $1: 2$. After the increase in nitrogen, the rate of 1,1-DCE decreased to $0.08 \mathrm{ug} / \mathrm{h}$ and increased to $0.24 \mathrm{ug} / \mathrm{h}$ for $1,2-\mathrm{DCE}$, corresponding to a 1,1-DCE to 1,2-DCE ratio of $1: 3$. It seems apparent that the increase in nitrogen level influenced the production of daughter products.

\subsubsection{Effect of TCE Concentration}

Last quarter a TCE feed concentration of $5.0 \mathrm{mg} / \mathrm{L}$ was used. As already noted, the TCE concentration was reduced from 5.0 to $1.6 \mathrm{mg} / \mathrm{L}$ on $1 / 14$ to evaluate possible concentration effects on performance. This new TCE concentration corresponded to a loading rate of $0.326 \mathrm{mg} / \mathrm{d}$ L or $9.78 \times 10^{-3} \mathrm{mg} / \mathrm{d}$ $\mathrm{cm}^{2}$. Examination of Figure 2 shows that an average mass removal rate of about $5.5 \mathrm{ug} / \mathrm{h}$ TCE was obtained, corresponding to about $58 \%$ removal. It is interesting to note (see Figure 1) that most of the TCE removal occurred at the bottom port (the first four inches of the column). Only about 1 to $2 \%$ additional removal occurred from the bottom to the top port of the column. On February 1, 1995, the column was reseeded with $120 \mathrm{~mL}$ effluent from the maintenance reactor to improve the degradation at the middle and top ports. But, the results indicated that no increase in degradation occurred at the top two ports.

On March 7, the influent concentration of TCE to the column was increased to the $5.0 \mathrm{mg} / \mathrm{L}$ and has been continued until the end of the period (March 31). The TCE loading rates for this concentration of TCE was $0.0306 \mathrm{mg} / \mathrm{d} \mathrm{cm}^{2}$ or 1.02 $\mathrm{mg} / \mathrm{d} \mathrm{L}$. The column was operated under the conditions presented in Table 1.

In Figures 6,7 and 8 , the mass flow rate data at each port, the mass of TCE removed $(\mathrm{ug} / \mathrm{h})$, and the percent removal are presented respectively. It should be pointed out that the methanol concentration was reduced after $3 / 14$ (Table 1 ) as will be discussed later. Prior to reducing the methanol level $(3 / 7-3 / 14)$, the rate of TCE removal averaged about $14.5 \mathrm{ug} / \mathrm{h}$ and the TCE removal averaged $67 \%$. 
In Figures 8 and 9 , the mass flow rate data of the daughter products are presented. As indicated in Eigure 8, the mass flow of 1, 1-DCE fell to essentially zero for a short period and then rose to about $0.11 \mathrm{ug} / \mathrm{h}$ while the formation rate of $1,2-D C E$ was about $0.23 \mathrm{ug} / \mathrm{h}$ providing a $1,1-D C E$ to $1,2-D C E$ ratio of $1: 2.1$.

Comparing the results of the two TCE concentrations, the mass removal rate and percentage removal of TCE were $14.5 \mathrm{ug} / \mathrm{h}$ and $67 \%$ respectively at the $5.0 \mathrm{mg} / \mathrm{L}$ feed level and 5.5 and $58 \%$ respectively at the $1.6 \mathrm{mg} / \mathrm{L}$ level. The rate of formation of daughter products (DP's) at the two feed levels (ug/h) was approximately the same. In addition, the actual concentration of DP's was approximately the same at the 1.6 and $5.0 \mathrm{mg} / \mathrm{L}$ TCE concentrations. For example, the concentration of 1,1-DCE in the column averaged 16.1 and $20.1 \mathrm{ppb}$ at the feed concentrations of 1.6 and $5.0 \mathrm{mg} / \mathrm{L}$ respectively. The concentration of $1,2-\mathrm{DCE}$ averaged 44.4 and $40.7 \mathrm{ppb}$ at the feed concentrations of 1.6 and $5.0 \mathrm{mg} / \mathrm{L}$ respectively.

\subsubsection{Effect of Methanol}

The effect of the concentration of the primary substrate (methanol) on TCE degradation was investigated at a feed TCE of $5.0 \mathrm{mg} / \mathrm{L}$. From $1 / 14 / 95$ to $3 / 13 / 95$, the concentration of methanol in the anaerobic column was $751 \mathrm{mg} / \mathrm{L}$. On $3 / 14 / 95$, the methanol concentration was decreased to $185.4 \mathrm{mg} / \mathrm{L}$. In Figures 6 to 8 , mass flow rate and percent removal data are presented. As the methanol concentration was decreased, the average mass rate of TCE removed fell from $14.5 \mathrm{to} 11.6 \mathrm{ug} / \mathrm{h}$ and the percent removal fell from 67 to 49 \%. As would be expected, the concentration of primary substrate has a significant effect on TCE degradation. For comparative purposes, it is interesting to note that only $37.5 \%$ removal of TCE occurred last quarter when feeding lower methanol and ammonia nitrogen concentrations of 176.3 and $7.68 \mathrm{mg} / \mathrm{L}$ respectively.

Figures 9 and 10 show the mass flow rate data for the daughter products. As noted earlier, at a methanol concentration of $751 \mathrm{mg} / \mathrm{L}$, the average 1,1-DCE and $1,2-D C E$ mass flow rates were 0.11 and $0.23 \mathrm{ug} / \mathrm{h}$ respectively. When the methanol level was lowered to $185.4 \mathrm{mg} / \mathrm{L}$, the corresponding mass flow rates were essentially unchanged at 0.11 and $0.20 \mathrm{ug} / \mathrm{h}$.

\subsubsection{Effect of Tcs slug}

On Eebruary 21, a TCE slug (approximately $19.0 \mathrm{mg} / \mathrm{L}$ ) was accidentally allowed to enter the system. This translates into a loading rate of $0.114 \mathrm{mg} / \mathrm{d}$ $\mathrm{cm}^{2}$ or $3.813 \mathrm{mg} / \mathrm{d} \mathrm{L}$. The excursion lasted for 72 hours (one syringe). After the high concentration was noted, the influent concentration was again dropped to approximately $1.6 \mathrm{mg} / \mathrm{L}$ on $2 / 24$. (It should be noted that only a relatively limited amount of data were taken during the excursion and hence the results should be considered only preliminary.) In Figure 11, the TCE concentration before and after the shock is presented showing that the column TCE rose to a maximum of around $5.0 \mathrm{mg} / \mathrm{L}$ at the bottom port and around $4 \mathrm{mg} / \mathrm{L}$ at the top port one day later. Figures 12 and 13 provide concentrations of TCE and the daughter products $(X 100)$ at the bottom and top ports respectively.

At the bottom port (four inches up the column), the 1,1-DCE rose and fell in concert with the TCE while the 1,2-DCE appears to form at a high rate immediately after the shock and then fall off rapidly. The pattern for the daughter products is approximately the same at the top port after a delay of about one day (Figure 13). 
Table 2. Composition of media.

\begin{tabular}{|c|c|c|c|}
\hline Chemical & $\begin{array}{l}\text { Conc. in stock } \\
\text { solution }\end{array}$ & $\begin{array}{l}\text { Conc in } \\
\text { Media/Syringe }\end{array}$ & $\begin{array}{l}\text { Conc entering } \\
\text { column }\end{array}$ \\
\hline $\mathrm{NH}_{4} \mathrm{Cl}$ & $200 \mathrm{mg} / \mathrm{L}$ & $8 \mathrm{mg} / \mathrm{L}$ & $7.68 \mathrm{mg} / \mathrm{L}$ \\
\hline $\mathrm{K}_{2} \mathrm{HPO}_{4}$ & $76 \mathrm{mg} / \mathrm{L}$ & $3.04 \mathrm{mg} / \mathrm{L}$ & $2.92 \mathrm{mg} / \mathrm{L}$ \\
\hline $\mathrm{KH}_{2} \mathrm{PO}_{1}$ & $55 \mathrm{mg} / \mathrm{L}$ & $2.2 \mathrm{mg} / \mathrm{L}$ & $2.11 \mathrm{mg} / \mathrm{L}$ \\
\hline $\mathrm{MgCl}_{2} * 6 \mathrm{H}_{2} \mathrm{O}$ & $150 \mathrm{mg} / \mathrm{L}$ & $6 \mathrm{mg} / \mathrm{L}$ & $5.76 \mathrm{mg} / \mathrm{L}$ \\
\hline $\mathrm{MnCl}_{2} \star 4 \mathrm{H}_{2} \mathrm{O}$ & $50 \mathrm{mg} / \mathrm{L}$ & $2 \mathrm{mg} / \mathrm{L}$ & $1.92 \mathrm{mg} / \mathrm{L}$ \\
\hline $\mathrm{CoCl}_{2} \star 6 \mathrm{H}_{2} \mathrm{O}$ & $100 \mathrm{mg} / \mathrm{L}$ & $4 \mathrm{mg} / \mathrm{L}$ & $3.84 \mathrm{mg} / \mathrm{L}$ \\
\hline $\mathrm{ZnCl}_{2}$ & $50 \mathrm{mg} / \mathrm{L}$ & $2 \mathrm{mg} / \mathrm{L}$ & $1.92 \mathrm{mg} / \mathrm{L}$ \\
\hline $\mathrm{CaCl}_{2} * 2 \mathrm{H}_{2} \mathrm{O}$ & $165 \mathrm{mg} / \mathrm{L}$ & $6.6 \mathrm{mg} / \mathrm{L}$ & $6.34 \mathrm{mg} / \mathrm{L}$ \\
\hline $\mathrm{HBO}_{3}$ & $15.1 \mathrm{mg} / \mathrm{L}$ & $0.604 \mathrm{mg} / \mathrm{L}$ & $0.580 \mathrm{mg} / \mathrm{L}$ \\
\hline $\mathrm{NiCl}_{2} \star 6 \mathrm{H}_{2} \mathrm{O}$ & $50 \mathrm{mg} / \mathrm{L}$ & $2 \mathrm{mg} / \mathrm{L}$ & $1.92 \mathrm{mg} / \mathrm{I}$ \\
\hline $\mathrm{Na}_{2} \mathrm{MOO}_{4} * 2 \mathrm{H}_{2} \mathrm{O}$ & $20 \mathrm{mg} / \mathrm{L}$ & $0.8 \mathrm{mg} / \mathrm{L}$ & $0.768 \mathrm{mg} / \mathrm{I}$ \\
\hline $\begin{array}{r}\text { L-Cysteine } \\
\mathrm{C}_{3} \mathrm{H}_{7} \mathrm{NO}_{2} \mathrm{~S} * \mathrm{HCl}{ }^{*} \mathrm{H}_{2} \mathrm{O}\end{array}$ & $450 \mathrm{mg} / \mathrm{L}$ & $18 \mathrm{mg} / \mathrm{L}$ & $17.28 \mathrm{mg} / \mathrm{L}$ \\
\hline $\mathrm{NaHCO}_{3}$ & $2000 \mathrm{mg} / \mathrm{L}$ & $80 \mathrm{mg} / \mathrm{L}$ & $76.8 \mathrm{mg} / \mathrm{L}$ \\
\hline Yeast Extract & $50 \mathrm{mg} / \mathrm{L}$ & $2 \mathrm{mg} / \mathrm{I}$ & $1.92 \mathrm{mg} / \mathrm{L}$ \\
\hline $\mathrm{FeCl}_{2} \star 4 \mathrm{H}_{2} \mathrm{O}$ & $30 \mathrm{mg} / \mathrm{L}$ & $1.2 \mathrm{mg} / \mathrm{L}$ & $1.15 \mathrm{mg} / \mathrm{L}$ \\
\hline Resazurin & $0.001 \mathrm{mg} / \mathrm{L}$ & $0.04 \mathrm{ug} / \mathrm{L}$ & $0.0384 \mathrm{ug} / \mathrm{L}$ \\
\hline TCE & $10000 \mathrm{mg} / \mathrm{L}$ & $125 \mathrm{mg} / \mathrm{L}$ & $5.0 \mathrm{mg} / \mathrm{L}$ \\
\hline $\mathrm{Na}, \mathrm{CO}_{3}$ & $30000 \mathrm{mg} / \mathrm{L}$ & $6000 \mathrm{mg} / \mathrm{L}$ & $264 \mathrm{mg} / \mathrm{L}$ \\
\hline $\mathrm{CH}_{3} \mathrm{COOH}$ & $1049000 \mathrm{mg} / \mathrm{L}$ & $4582 \mathrm{mg} / \mathrm{L}$ & $183 \mathrm{mg} / \mathrm{L}$ \\
\hline $\mathrm{CH}_{3} \mathrm{OH}$ & $792400 \mathrm{mg} / \mathrm{L}$ & $4634 \mathrm{mg} / \mathrm{L}$ & $185 \mathrm{mg} / \mathrm{L}$ \\
\hline
\end{tabular}

A rough mass balance was performed in order to estimate removal for the three days the slug was fed to the system and the next 9 days (in total, February 21 until March 4i until the system once again produced a constant effluent. It was estimated that the system achieved an overall TCE removal of around $49 \%$ in handling the shock load. It is concluded that the methanogens were able to handle a short term ( 3 day) shock which was an order of magnitude higher than they had been receiving with no undue stress on the system. TCE removal returned to normal within a relatively short period (about 7 days) after cessation of the slug load. The system will be subjected to a planned series of shock lcads in future quarters as was proposed in the work plan. 


\subsubsection{Summary of Performance Data for Quarter}

Table 3 provides a summary of performance data for the variety of conditions evaluated during the quarter.

Table 3. Summary of Performance Data-Anaerobic Column

\begin{tabular}{|l|l|l|l|l|l|l|l|}
\hline Period & $\begin{array}{l}\text { Feed } \\
\mathrm{TCE} \\
(\mathrm{mg} / \mathrm{L})\end{array}$ & $\begin{array}{l}\mathrm{CH}_{3} \mathrm{OH} \\
(\mathrm{mg} / \mathrm{L})\end{array}$ & $\begin{array}{l}\mathrm{NH}_{4}-\mathrm{N} \\
(\mathrm{mg} / \mathrm{L})\end{array}$ & $\begin{array}{l}\mathrm{TCE} \\
\text { Rem. } \\
(\mathrm{ug} / \mathrm{h})\end{array}$ & $\begin{array}{l}\frac{2}{2} \mathrm{TCE} \\
\text { Rem. }\end{array}$ & $\begin{array}{l}1,1-\mathrm{DCE} \\
(\mathrm{ug} / \mathrm{h})\end{array}$ & $\begin{array}{l}\text { 1,2-DCE } \\
(\mathrm{ug} / \mathrm{h})\end{array}$ \\
\hline $\begin{array}{l}1 / 14- \\
1 / 23\end{array}$ & 1.6 & 751 & 8 & 1.2 & 10 & .11 & .22 \\
\hline $\begin{array}{l}1 / 24- \\
2 / 20\end{array}$ & 1.6 & 751 & 55 & 5.5 & 58 & 0.08 & 0.24 \\
\hline $\begin{array}{l}2 / 21- \\
2 / 23\end{array}$ & 19.0 & 751 & 55 & - & 49 & -- & -- \\
\hline $\begin{array}{l}3 / 7- \\
3 / 14\end{array}$ & 5.0 & 751 & 55 & 14.5 & 67 & .11 & .23 \\
\hline $\begin{array}{l}3 / 14- \\
3 / 31\end{array}$ & 5.0 & 185 & 55 & 11.6 & 49 & .11 & .20 \\
\hline Last QTR & 5.0 & 176 & 8 & 11.5 & 37.5 & .10 & .23 \\
\hline
\end{tabular}

\subsection{Aerobic studies}

\subsubsection{Aerobic Colum studies}

Evaluation of the aerobic mineralization of TCE using methanotrophs and other heterotrophs in an upflow column was continued this quarter. Parameters investigated this quarter include the concentration of primary substrate (methanol) and an alternative electron acceptor (hydrogen peroxide). A shock load of TCE was inadvertently fed to the column for a short period allowing an evaluation of system response to a slug load.

Methanotrophic bacteria produce methane monoxygenase (MMO) to begin catabolism of methane (the primary substrate) for assimilation into biomass or mineralization. Fortunately, the MMO is relatively non-specific, and the enzyme also is active (cometabolically) in transforming TCE to TCE-epoxide. The epoxide is unstable and undergoes chemical abiotic transformation to TCE-diol and eventually biological mineralization to $\mathrm{CO}_{2}$ and $\mathrm{H}_{2} \mathrm{O}$. It is the nature of cometabolic processes that the presence of the primary substrate both increases cometabolic transformation by increasing the available biomass and decreases cometabolic transformation by competing for the active site of the enzyme. The competitive inhibition of methane has been demonstrated both in the laboratory and the field (Semprini, 1994). Contrary to the expectation the presence of methane is inhibitory to TCE degradation are the results of work by Smith (1993, EPA Proceedings) indicating that transformation of high concentrations of TCE (5 
to $9 \mathrm{mg} / \mathrm{L}$ ) was enhanced by the presence of methane. Additional research (Speitel, 1991) has indicated that low concentrations of methane (1 $\frac{\circ}{\circ}$ methane/air atmosphere) or $1.5 \mathrm{mg} / \mathrm{L}$ (Lanzarone, 1990) did not result in inhibition of TCE oxidation. These investigators also demonstrated the ability of methanotophs to continue TCE oxidation for several weeks in the absence of methane. It is clear that careful application of methane, either in a pulse feed mode or at low concentrations will be necessary to avoid problems with competitive inhibition.

While the MMO enzyme is responsible for the initial epoxidation of methane to methanol, other enzymes are responsible for further metabolism for biomass assimilation or energy production in the form of reduced nicotinamide adenine dinucleotide $\left(\mathrm{NADH}_{2}\right)$. Further oxidation of methane oxidation products (methanol, formaldehyde and formate) yields reducing equivalents in the form of NADH. Methanol has been investigated as both an electron acceptor and a carbon source. Broholm et al. (1993) reported field investigations showing TCE transformation could be supported by methanol addition in the absence of methanol for a period of 60 hours. Thus, the addition of methanol as an alternative primary substrate to methanol as a source of electrons and as a growth substrate along with pulse feeding of methane seems an attractive alternative to maintain a viable population while avoiding problems with competitive inhibition of methane. As will be noted in further detail later, work planned for next quarter includes the pulse feeding of methane augmented by methanol addition.

Methane and Methanol are being used as the primary substrates to accomplish oxidation of TCE. The concentrations of TCE, methanol, and hydrogen peroxide fed to the column this quarter are shown in Table 4. Methane was added as noted in earlier reports by sparging into the groundwater once per week at the Medical Center. On $3 / 25$, a methane addition setup was established at the Engineering Building and methane was sparged into the groundwater every three days. At the end of this reporting period on $4 / 6$, pulse addition of methane was initiated. The composition of the basal salts media utilized is presented in Table 5. The column was operated at a hydraulic retention time of 24 hours with a feed flow rate of approximately $10.2 \mathrm{~mL} /$ hour. The effluent temperature, $\mathrm{pH}$, and Do were measured daily. Temperature ranged from $24^{\circ} \mathrm{C}$ to $29^{\circ} \mathrm{C}$.

Data from $12 / 16 / 94$ to $1 / 14 / 95$ are presented in Eigures 14 and 15 . The $\mathrm{pH}$ was consistent at 6.8 to 6.9 . The Do varied between 2.9 and 4.3 for the time period. The ground water flow rate through the column ranged between $7.06 \mathrm{ml} / \mathrm{hr}$ and 10.88 $\mathrm{ml} / \mathrm{hr}$. The column was fed $5.0 \mathrm{mg} / 1$ of $\mathrm{TCE}$ at a rate of $0.2 \mathrm{ml} / \mathrm{hr}$ using a syringe pump. Variation in the ground water flow was taken into account while determining the influent TCE concentrations.

The concentration of TCE (ppb) at the bottom, middle, and top ports is shown in Figure 14. Figure 15 shows the overall percentage removal at the top port. An apparent negative overall percentage removal of $-22.68 \%$ was observed at the top port. The apparent negative percentage removal was due to the malfunction of the syringe plunger pump. The syringe was apparently moving independently from the pusher block of the pump. The flow rate was set at $0.2 \mathrm{~mL} / \mathrm{hr}$, but due the malfunction it varied from 0.197 to $1.75 \mathrm{ml} / \mathrm{hr}$ causing a slug of high TCE concentration in the column. A variety of steps were taken to solve the problem over a period of time and finally a new pump had to be obtained.

The slug through the column was monitored at the three ports from $1 / 16$ to $1 / 23$. TCE delivery was stopped on $1 / 20$. The data is presented in Figure 16 . At the top port, the concentration increased to $12.87 \mathrm{mg} / \mathrm{L}$ for the first six hours and then suddenly decreased to $8.5 \mathrm{mg} / \mathrm{L}$ in the next three hours. A similar pattern of an increase followed by a decrease in concentration was observed in the next 
Table 4. Column Conditions $(12 / 16 / 94-4 / 6 / 95)$

\begin{tabular}{|c|c|c|c|c|c|c|}
\hline Time span & $\begin{array}{l}\text { Desired* } \\
\text { effluent } \\
\text { flow rate } \\
(\mathrm{ml} / \mathrm{hr})\end{array}$ & $\begin{array}{l}\text { Effluent } \\
\text { Do } \\
(\mathrm{mg} / \mathrm{L})\end{array}$ & $\mathrm{pH}$ & $\begin{array}{l}\text { Influent } \\
\text { methanol } \\
\text { conc } \\
\text { (ppm) }\end{array}$ & $\begin{array}{l}\text { Influent } \\
\text { TCE conc } \\
\text { (ppm) }\end{array}$ & $\begin{array}{l}\text { Influent } \\
\mathrm{H}_{2} \mathrm{O}_{2} \text { conc } \\
\text { (ppm) }\end{array}$ \\
\hline $\begin{array}{l}12 / 16 / 94 \\
-1 / 14 / 95\end{array}$ & 10.2 & 3.5 & 6.8 & 5 & $5^{1}$ & - \\
\hline $\begin{array}{l}1 / 20 / 95- \\
1 / 26 / 95 \\
\text { (TCE sIug } \\
\text { passage } \\
\text { analysis) }\end{array}$ & 10.2 & 4.1 & 6.9 & 5 & $0^{2}$ & - \\
\hline $\begin{array}{l}2 / 9 / 95-^{-3} \\
2 / 26 / 95\end{array}$ & 10.2 & 4.3 & 7.0 & 5 & 5 & - \\
\hline $\begin{array}{l}2 / 27 / 95- \\
3 / 8 / 95\end{array}$ & 10.2 & 4.2 & 7.0 & 7.7 & 5 & - \\
\hline $\begin{array}{l}3 / 9 / 95- \\
3 / 17 / 95\end{array}$ & 10.2 & 4.0 & 7.0 & 7.8 & 5 & 25 \\
\hline $\begin{array}{l}3 / 18 / 95- \\
4 / 1 / 95\end{array}$ & 10.2 & 5.4 & 7.1 & 15.7 & 5 & 50 \\
\hline $\begin{array}{l}4 / 2 / 95- \\
4 / 5 / 95\end{array}$ & 10.2 & 7.7 & 7.0 & 23.5 & 5 & 75 \\
\hline $4 / 6 / 95^{4}-$ & 10.2 & 7.7 & $\because 2$ & $32^{5}$ & 5 & 75 \\
\hline
\end{tabular}

${ }^{1}$ Actual concentration was much higher due to syringe malfunction

${ }^{2}$ After slug passage

${ }^{3}$ Additional methanotrophs were added to the column on $2 / 11 / 95$

${ }^{4}$ Pulse feeding of methane started

5 to make up for effluent DO

* for a column detention time of 24 hrs 
twelve hours. The maximum concentration recorded was $10.8 \mathrm{mg} / \mathrm{L}$. Thereafter a steady decrease in the concentration has been observed. By 8:42 AM on 1/23/95 the concentration came down to $0.6 \mathrm{mg} / \mathrm{L}$. At the middle and bottom ports, a steady decrease in TCE concentration was observed as expected.

6.2.2 Effect of Methanol and Hydrogen Peroxide In order to improve TCE removal, it was desired to increase the level of methanol added to the column. The amount of methanol has been kept at the $5 \mathrm{mg} / \mathrm{l}$ level in the feed so as not to stimulate biological growth to the extent that the dissolved oxygen level would fall producing anaerobic conditions in the column. Limitations with respect to DO level may be overcome by adding an alternative hydrogen acceptor such as hydrogen peroxide as discussed below.

The effect of methanol and hydrogen peroxide on TCE degradation was investigated at a target feed TCE of $5 \mathrm{mg} / \mathrm{L}$ as shown in Figures 17 to 20 . From $2 / 9$ to $2 / 26$, the concentration of methanol was maintained at $5 \mathrm{mg} / \mathrm{L}$. Examination of the figures shows an apparent negative removal of TCE during this period. Careful tracking of the flows into the column revealed another pump problem in that the peristaltic pump feeding the groundwater fluctuated in flow rate as much as plus or minus $35 \%$ from day to day causing major swings in the concentration of TCE entering the column. Since funds were not available to purchase a better pump during this period, more attention was given to frequent flow rate adjustment.

Erom $2 / 27$ to $3 / 8$, the methanol concentration was increased slightly from 5 to 7.7 $\mathrm{mg} / \mathrm{L}$. As may be noted on Figures 17 to 19 , the overall removal rate and percentage removal at the top port were increased to $1.7 \mathrm{ug} / \mathrm{hr}$ and 3.68 , respectively. However, flow rate problems still persist as may be noted from the significant fluctuations in TCE concentration.

From $3 / 9 / 95$ to $3 / 30 / 95, \mathrm{H}_{2} \mathrm{O}_{2}$ was fed to the column as an alternative electron acceptor in order to allow larger increases in the methanol level. It was desired to increase the methanol to around $30 \mathrm{mg} / \mathrm{l}$ with a goal to provide a $\mathrm{CH}_{3} \mathrm{OH} / \mathrm{TCE}$ ratio of 6 . Based on the equation shown below, $96 \mathrm{ppm}$ of $\mathrm{H}_{2} \mathrm{O}_{2}$ will be required in the column (conservative estimate assuming no synthesis). However, to avoid a possible toxic shock to the microorganisms due to the $96 \mathrm{mg} / \mathrm{L}$ of $\mathrm{H}_{2} \mathrm{O}_{2}$, the concentration of peroxide was raised in $25 \mathrm{mg} / \mathrm{L}$ increments per week.

$$
3 \mathrm{H}_{2} \mathrm{O}_{2}+\mathrm{CH}_{3} \mathrm{OH} \rightarrow 5 \mathrm{H}_{2} \mathrm{O}+\mathrm{CO}_{2}
$$

Table $\sigma$ below shows the concentrations of methanol to be added in the column for the varying concentrations of $\mathrm{H}_{2} \mathrm{O}_{2}$.

The concentration of $\mathrm{H}_{2} \mathrm{O}_{2}$ in the ground water was monitored daily using a $\mathrm{H}_{2} \mathrm{O}_{2}$ kit (CHEMetrics, Inc., VA.) and any deviation from the required concentration was corrected by adding additional $\mathrm{H}_{2} \mathrm{O}_{2}$. As may be noted in Table 4, the $\mathrm{H}_{2} \mathrm{O}_{2}$ concentration was gradually increased to around $50 \mathrm{mg} / \mathrm{L}$ by the end of the quarter allowing a corresponding increase in methanol to around $16 \mathrm{mg} / \mathrm{L}$. Examination of Figures 18 and 19 show that the overall removal rate and percentage removal at the top port averaged about $9 \mathrm{ug} / \mathrm{h}$ and $20 \%$, respectively. It is anticipated that TCE removal will improve as the methanol concentration is increased. As may be noted on Figure 20, the Do concentration increased from 2.69 to $7.35 \mathrm{mg} / \mathrm{L}$ after addition of hydrogen peroxide. 
Table 5. Composition of Aerobic Column Feed

\begin{tabular}{|c|c|c|}
\hline Compound & $\begin{array}{l}\text { Concentration in the } \\
\text { stock solution }(\mathrm{mg} / \mathrm{l})\end{array}$ & $\begin{array}{l}\text { Concentration in the } \\
\text { Feed }(\mathrm{mg} / \mathrm{l})\end{array}$ \\
\hline \multicolumn{3}{|l|}{$\begin{array}{l}\text { Higgins Medium at } 9: 1 \\
\text { dilution }\end{array}$} \\
\hline $\mathrm{NaNO}_{3}$ & 850 & 85 \\
\hline $\mathrm{KH}_{2} \mathrm{PO}_{4}$ & 530 & 53 \\
\hline $\mathrm{Na}_{2} \mathrm{HPO}_{4}$ & 860 & 86 \\
\hline $\mathrm{K}_{2} \mathrm{SO}_{4}$ & 170 & 17 \\
\hline $\mathrm{MgSO}_{4} \cdot 7 \mathrm{H}_{2} \mathrm{O}$ & 37 & 3.7 \\
\hline $\mathrm{CaCl}_{2} \cdot 2 \mathrm{H}_{2} \mathrm{O}$ & 7 & 0.7 \\
\hline \multicolumn{3}{|l|}{ Trace Elements } \\
\hline $\mathrm{EeSO}_{1} \cdot 7 \mathrm{H}_{2} \mathrm{O}$ & 0.5 & .05 \\
\hline $\mathrm{ZnSO}_{4} \cdot 7 \mathrm{H}_{2} \mathrm{O}$ & 0.4 & .04 \\
\hline $\mathrm{MnCl}_{2} \cdot 4 \mathrm{H}_{2} \mathrm{O}$ & .02 & .002 \\
\hline $\mathrm{CoCI}_{2} \cdot 6 \mathrm{H}_{2} \mathrm{O}$ & .05 & .005 \\
\hline $\mathrm{NiCl}_{2} \cdot 6 \mathrm{H}_{2} \mathrm{O}$ & .01 & .001 \\
\hline $\mathrm{H}_{3} \mathrm{BO}_{3}$ & .015 & .0015 \\
\hline EDTA & .25 & .0025 \\
\hline $\mathrm{CuSO}_{4} \cdot 5 \mathrm{H}_{2} \mathrm{O}$ & 2496 & .0125 \\
\hline \multicolumn{3}{|l|}{$\begin{array}{l}\text { Phosphate Buffer (pH } \\
6.8 \text { ) e } 1 \mathrm{ml} / 100 \mathrm{ml} \text { broth }\end{array}$} \\
\hline $\mathrm{KHPO}_{4}$ & 260 & 2.6 \\
\hline $\mathrm{Na} 2 \mathrm{HPO} 4$ & 330 & 3.3 \\
\hline \multicolumn{3}{|l|}{ vitamins } \\
\hline Biotin & .02 & .0002 \\
\hline Eolic Acid & .02 & .0002 \\
\hline Thiamine $\mathrm{HCl}$ & .05 & .0005 \\
\hline Calcium Pantothenate & .05 & .0005 \\
\hline B12 & .01 & .0001 \\
\hline Riboflavin & .05 & .0005 \\
\hline Nicotamide & .05 & .0005 \\
\hline
\end{tabular}


Table 6. Hydrogen Peroxide and Associated Methanol Concentrations

\begin{tabular}{|c|c|}
\hline $\mathrm{H}_{2} \mathrm{O}_{2}(\mathrm{mg} / \mathrm{L})$ & $\mathrm{CH}_{3} \mathrm{OH}(\mathrm{mg} / \mathrm{L})$ \\
\hline 25 & 7.8 \\
\hline 50 & 15.7 \\
\hline 75 & 23.5 \\
\hline 96 & 30.1 \\
\hline
\end{tabular}

As noted earlier, methane (primary substrate) may actually interfere with removal of TCE by competitive inhibition. It was therefore decided to begin pulse feeding of methane by alternating the use of methane sparged and unsparged groundwater every other day. Pulse feeding was begun on $4 / 6$ and early results are encouraging.

\subsection{Other Project Activities}

\subsubsection{Subtask 1.1:Optimization of Sequential Mineralization}

It is planned to join the anaerobic and aerobic columns together to accomplish sequential mineralization of the TCE with recycle of methane. Planning to join the columns was carried out this quarter and a new pump was ordered when the funds became available in March. The columns will be joined once the results of methane pulsing to the aerobic columns have been determined and when the pump arrives. It is anticipated that this will occur early in the next quarter.

\subsubsection{Subtask 1.2 :Design and Construction of the simultaneous Mineralization Column}

This subtask is to design and construct a system to accomplish mineralization of $T C E$ in a simultaneous mode. It is planned to try to provide conditions where methanogens and methanotrophs can function in close proximetry with recyling of methane and endproducts from one group of organisms to another. To accomplish simultaneous mineralization, short anaerobic and aerobic zones will be setup alone the column. The bulk dissolved oxygen level will be kept low in the aerobic zones so as to allow microzones of anaerobic biological activity alone the entire flow path. The column (two feet long) was planned and designed this quarter including location of feed and sampling ports. It will require four new pumps. When the funds became available in March, the columns and necessary fittings and pumps were ordered. The column and supplies should arrive shortly and the column will be taken to the glassblower for the required modifications. It is anticipated that the column will be operational early in the next quarter.

\subsubsection{Subtask 1.3:Development of Protocol to Locate Anaerobic and Aerobic zones}

As noted in the proposal, it would be of value to know the location of where the anaerobic and aerobic zones exist in the columns. To this end, a literature search was carried out to determine if other workers had developed and used probes or other devices for this purpose. As expected, it was found that a number of workers (Gupta et al., 1994; Koch, 1985, Gupta, 1993) had measured oxidation potential (ORP) to help in determining the presence or absence of 
aerobic or anaerobic conditions. However, in the cases noted where ORP was measured, the sample was removed from the system for measurement or the flows were considerably larger than in our system allowing a sample to be pumped out of the system to a measurement loop and then returned.

For our system, it was decided that any measurement to locate anaerobic and aerobic zones would have to satisfy the following conditions:

(1) the analysis should be performed in the column without removing the sample so as not to lose any of the very volatile chorinated aromatic hydrocarbons (CAH's);

(2) the size of any electrode must be small so as not to interfere with flow the water in the column;

(3) since the velocity in the column is so slow, the electrode must be able to function at extremely low velocities;

(4) any measuring device must be able to function "in place" for at least 6 to 8 months without cleaning or renewing.

A number of companies were contacted to determine whether they could provide a workable electrode meeting the above specifications and literature was received from some of them. Two of the companies expressed an interest in working with us, but none of them had any direct experience with our application or could provide any reasonably firm guarantees that their electrode would work in our column. After consideration of the potential odds of success in this matter and evaluation of the delay in other project tasks that might occur as we attempted to install and evaluate the electrode, it was decided to stop work on this task. If further review of the literature suggests higher odds of success and time permits, we will consider further work on this issue later.

\section{0 coNCLUSIONS}

The anaerobic column was operated this quarter under a variety of conditions. Parameters investigated included TCE concentration, potential nitrogen limitation, methanol feed level and response to a short-term TCE shock.

It was found that an increase in the ammonia nitrogen level in the feed (from 8 to $55 \mathrm{mg} / \mathrm{L}$ ) significantly improved TCE removal (from 10 to 58 \% Hence, it seems apparent that the ammonia nitrogen level in the feed was limiting. TCE feed levels of 1.6 and $5.0 \mathrm{mg} / \mathrm{L}$ were evaluated with respect to column performance. It was found that the removal of TCE improved from 58 to 67 is the feed concentration was increased from 1.6 to $5.0 \mathrm{mg} / \mathrm{L}$. The mass removal rate of TCE increased from $5.5 \mathrm{ug} / \mathrm{h}$ at $1.6 \mathrm{mg} / \mathrm{L}$ to $14.5 \mathrm{ug} / \mathrm{h}$ at the $5.0 \mathrm{mg} / \mathrm{L} \mathrm{TCE}$ concentration. However, the concentration of daughter products was about the same at both feed TCE levels.

As expected, the feed concentration of the primary substrate (methanol) had a significant effect on TCE removal. As methanol was increased from 185 to 751 $\mathrm{mg} / \mathrm{L}, \mathrm{TCE}$ removal improved from 49 to 67 \& respectively. A slug of TCE (about $19.0 \mathrm{mg} / \mathrm{L}$ ) inadvertently entered the system for about three days. It was found that the methanogens were able to handle the shock load and still achieve an overall removal of about 49 with no apparent toxic effects.

The aerobic column was operated this quarter under a variety of conditions. Parameters investigated included the concentration of primary substrate 
(methanol) and an alternative electron acceptor (hydrogen peroxide). A shock load of TCE was accidentally fed to the column for a short period allowing an evaluation of system response to a slug load.

It was found that the overall removal rate and percent TCE removed at the top port were $9 \mathrm{ug} / \mathrm{h}$ and $20 \%$ respectively. It is anticipated that TCE removal will continue to improve as the methanol concentration is increased. The Do concentration increased from 2.69 to $7.35 \mathrm{mg} / \mathrm{L}$ after addition of hydrogen peroxide.

A shock load of TCE was inadvertently fed to the column for a short period allowing an evaluation of system response to a slug load. At the top port, the concentration increased to $12.9 \mathrm{mg} / \mathrm{L}$ for the first six hours and then suddenly decreased to $8.5 \mathrm{mg} / \mathrm{L}$ in the next three hours. A similar pattern of an increase followed by a decrease in concentration was observed in the next twelve hours. The maximum concentration recorded was $10.8 \mathrm{mg} / \mathrm{L}$ and the concentration came down to $0.581 \mathrm{mg} / \mathrm{L}$. At the middle and bottom ports, a steady decrease in TCE concentration was observed as expected.

\section{O WORK PLANNED FOR NEXT OUARMGR}

The existing anaerobic and aerobic columns will be joined to evaluate sequential mineralization (Subtask 1.1). The systems will be joined after further data is gathered from the aerobic column with resect to potential benefits from the pulsing of methane instead of a continuous methane feed. We are also waiting for a pump to arrive before joining the columns. It is anticipated that the columns will be joined early in the next quarter.

As noted earlier, design of the simultaneous system (Subtask 1.2) has been accomplished and the necessary column, fittings and pumps have been ordered. When the column arrives, it will be modified by the glassblower. It is expected that the pumps and the column will be ready for initial system startup in May with a goal to optimization (Subtask 1.4).

Both the sequential and simultaneous systems will be operated using $\mathrm{H}_{2} \mathrm{O}_{2}$ as the electron acceptor. It is planned to operate both systems initially at a detention time of 48 hours and a TCE feed of $5.0 \mathrm{mg} / \mathrm{L}$. Assessment of bioremediation of high concentrations of TCE will be evaluated this quarter (Subtask 1.5) in one or both of the systems. Ports have been designed to add a high concentration shock of TCE to the columns.

Evaluation of prefabricated vertical drains (PVD's) for field application of amendments using lysimeters (Task 2) has been delayed since funds were not received until March. This task will be undertaken early in the next quarter with design and construction of the lysimeter.

\subsection{TECENICAL/ADMINISTRATIVE DIFTICULTIES}

Technical difficulties were experienced this quarter when the total organic carbon (TOC) analyzer malfunctioned. TOC measurements are helpful in evaluation of how much of the primary substrates have been utilized in the columns. Funds to fix the analyzer were located from another source at the end of the quarter and it is expected to be on-line by the end of April.

Administrative difficulties were experienced in that no funds were available for project activities until mid-March. This caused a delay in procurement of pumps, columns and associated supplies. As noted in section 5.0, progress on some of the 
tasks was reduced. Lacks of funds also caused considerable extra difficulty in providing alternative funds for necessary expenditures such as the payment of students salaries and supplies to keep the existing columns operational.

\subsection{REFERENCES}

Alvarez-Cohen, Lisa. (1993) "Engineering Challenges of Implementing In Situ Bioremediation." In Situ Bioremediation, When Does it Work? Committee on In Situ Bioremediation, NRC, National Academy Press, Washington, DC.

Bouwer, E., and McCarty, P. (1983) "Transformation of 1- and 2- Carbon Halogenated Aliphatic Organic Compounds Under Methanogenic Conditions, "Applied and Environmental Microbiology, 45 (6), 1286-1294.

Broholm, K., Christensen, T.H., and Jensen, B.K. 1993. "Different Abilities of Eight Mixed Cultures of Methane-Oxidizing Bacteria to Degrade Trichloroethylene." Water Resources. Vol. 27, p. 215-224.

Bruin, w., et al. (1992) "Complete Biological Reductive Transformation of Tetrachloroethane to Ethane," Applied and Environmental Microbiology, 58 (6), 1996-2000.

Chu, K.H. and Jewell, w.J. (1994) "Treatment of Tetrachloroethylene with Anaerobic Attached Film Process," Journal of Environmental Engineering 120(1), pp 58-71.

Dalton, H. and D.E. Stirling (1982) "Cometabolism", Philos. Trans. R. Soc. Lond., 297, pp 481-496.

Freedman, D.L. and J.M. Gossett (1989) "Biological Reductive Dechlorination of Tetrachlorethylene and Trichlorethylene to Ethylene Under Methanogenic Conditions", Appl. and Env. Microbiol., pp 2144-2151.

Gupta, M., Gupta, A, Suidan, M.T, Sayles and Flora, R.V. 1994. "ORP Measurement of Anaerobic Systems Using Flow-Through Cell." J.of Envir. Engr., Vol. 120, No. 6, Nov/Dec, pp. 1639-1645.

Gupta, M. Gupta, A, and Suidan, M.T 1993. "A Fundamental study of Anaerobic Biodegradation of Chloroform Under sulfate Reduction And Methanogenesis." Proc. of the $25 \mathrm{th}$ Mid-Atlantic Industrial Waste Conference, July 7-9, , U. of Md., College Pk., Md., Technomic Publ. Co., Lancaster, Pa.

Henry, Susan M. and Dunja Grbic-Galic. (1991) "Influence of Endogenous and Exogenous Electron Donors and TCE Oxidation Toxicity on TCE oxidation by Methanotrophic Cultures from a Groundwater Aquifer." Applied and Environmental Microbiology. Vol. 57, No.1 pp 236-244.

Henson, J.M. et al. (1988) "Microbial Removal of Halogenated Methanes, Ethanes and Ethylene in an Aerobic Soil Exposed to Methane", FEMS Microbiology Ecology, $53(3 / 4)$, pp 193-201.

Holtz, R.D., Kovacs, W.D. 1981. An Introduction to Geotechnical Engineering. Prentice-Hall, Inc., Englewood Cliffs, N.J.(ed)

Kaster, M. (1991) "Reductive Dechlorination of Tri- and Tetrachloroethylenes Depends on Transititon from Aerobic to Anaerobic Conditions", Appl. and Environ. 
Microbiology, Vol 57, No. 7, pp. 2039-46.

Koch, F.A and Oldham, W.K. 1985. "Oxidation-Reduction Potential-a Tool for Monitoring, Control and Optimization of Biological Nutrient Removal systems." Wat. Sci. and Techol., Vol 17, pp 259-281.

Lanzarone, N.A. and MCCarty, P.L. 1990. "Column Studies on Methanotrophic Degradation of Trichloroethene and 1,2-Dichloroethane." Ground Water, Vol. 28, No. 6, p. 910-919.

Oldenhuis, R, J. M. Ruud, D. B Janssen, and B Witholt (1989) "Degradation of Chlorinated Aliphatic Hydrocarbons by Methylosinus trichosporium OB 3 b Expressing Soluble Methane Monooxygenase". Applied and Environmental Microbiology, Vol 55, No. 11, pp 2819-2826.

Semprini, L. et al. 1994. "A field and modeling comparision of in situ transormation of TCE by methane utilizers and phenol utilizers." Bioremediation of Chlorinated and Polycyclic Aromatic Hydrocarbon Compounds.

Sims, J.L., R.C. Sims, and J.E. Mathews (1990) "Approach to Bioremediation of Contaminated Soil", Hazardous Waste and Hazardous Materials, V. 7, pp 117-149.

Vira, A., Byrnes, J., and Fogel, S. (1992) "Technological Requirements for the Maintenance of Specialized Cultures in the Subsurface Environment: Complete Biodegradation of PCE." 85th Annual Meeting \& Exhibition of the Air \& Waste Management Association, Kansas City, Mo. 
11.0 APPENDIX 1 


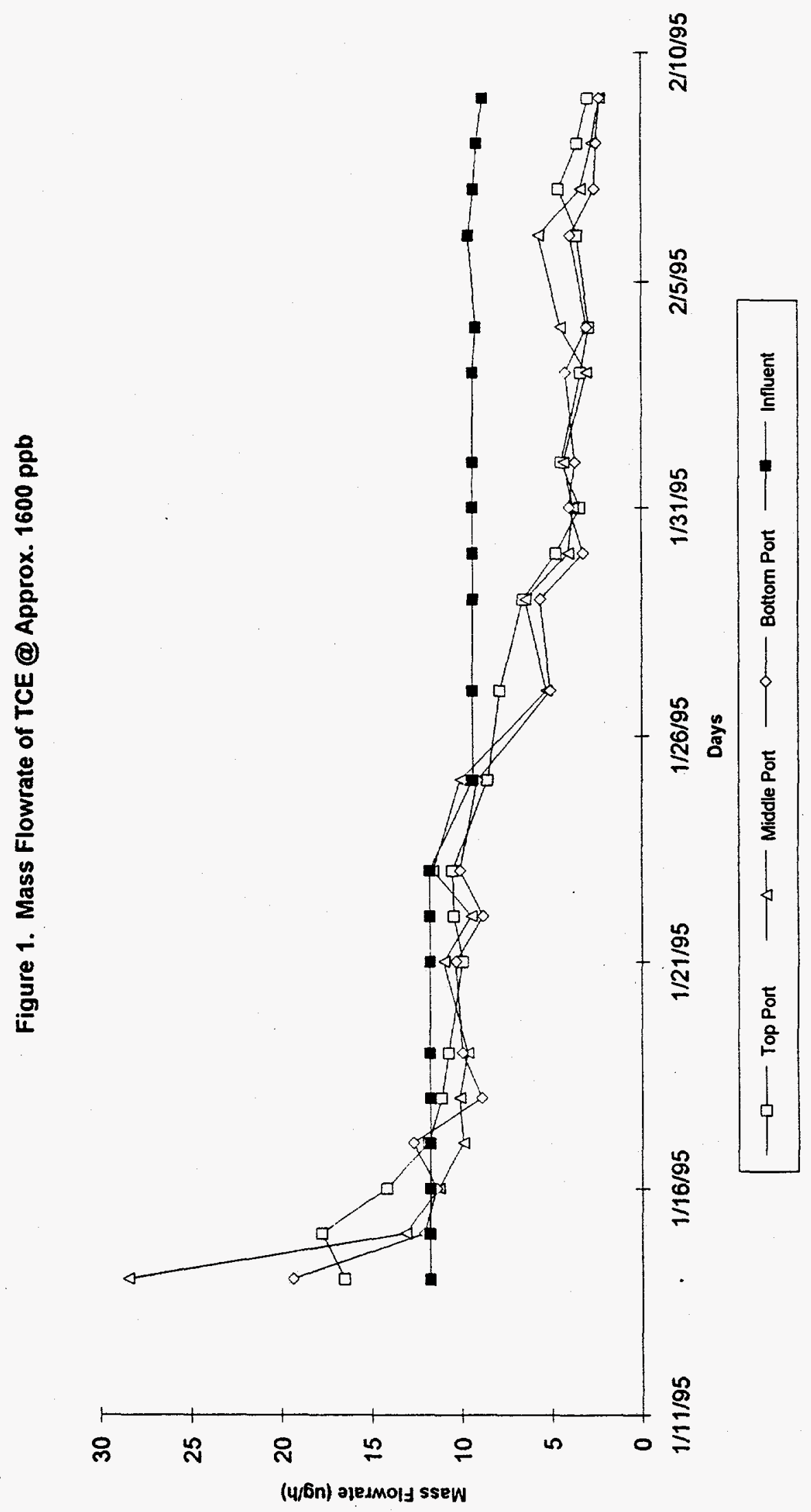




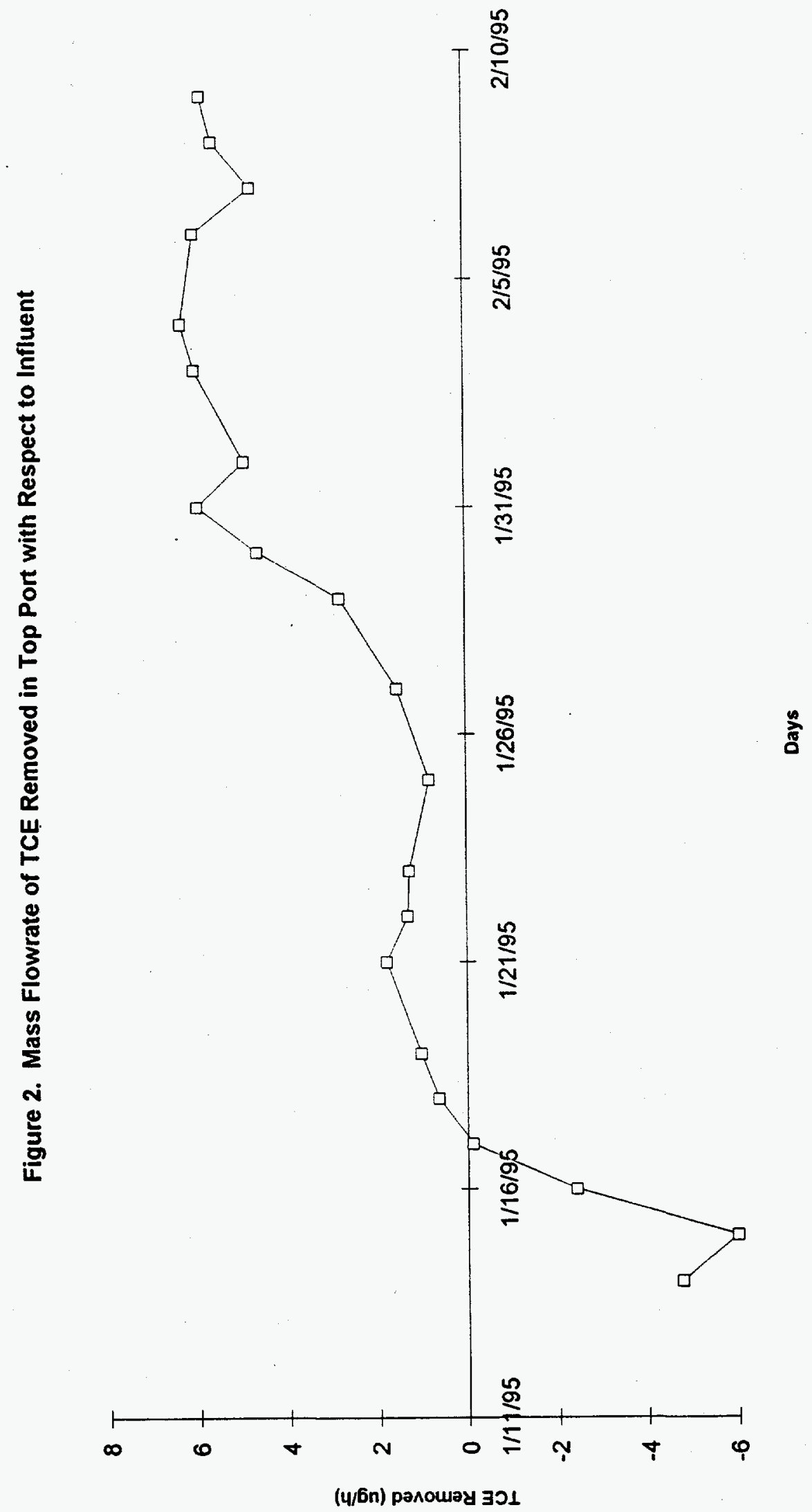


Figure 3. Percent Removal in Top Port with Respect to Influent

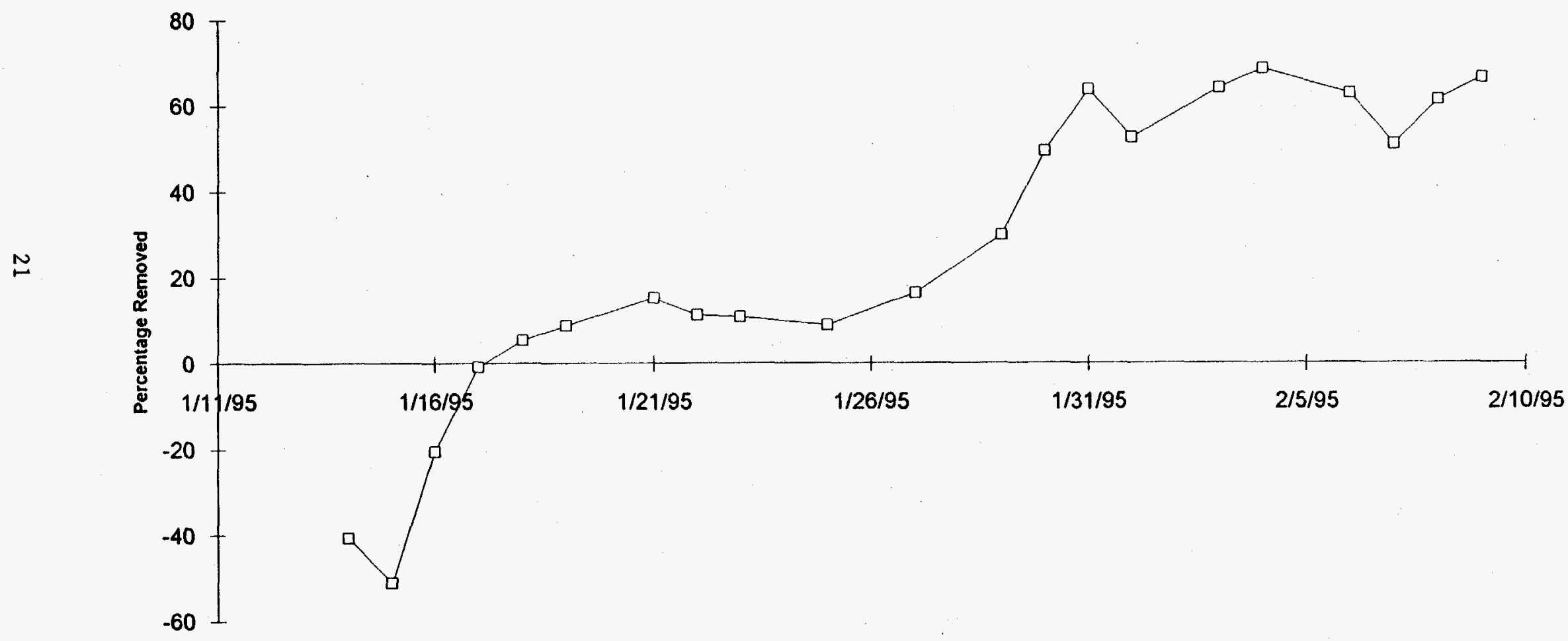

Days 
Figure 4. Mass Flowrate of 1,1-DCE @ Approx. 1600 ppb

N

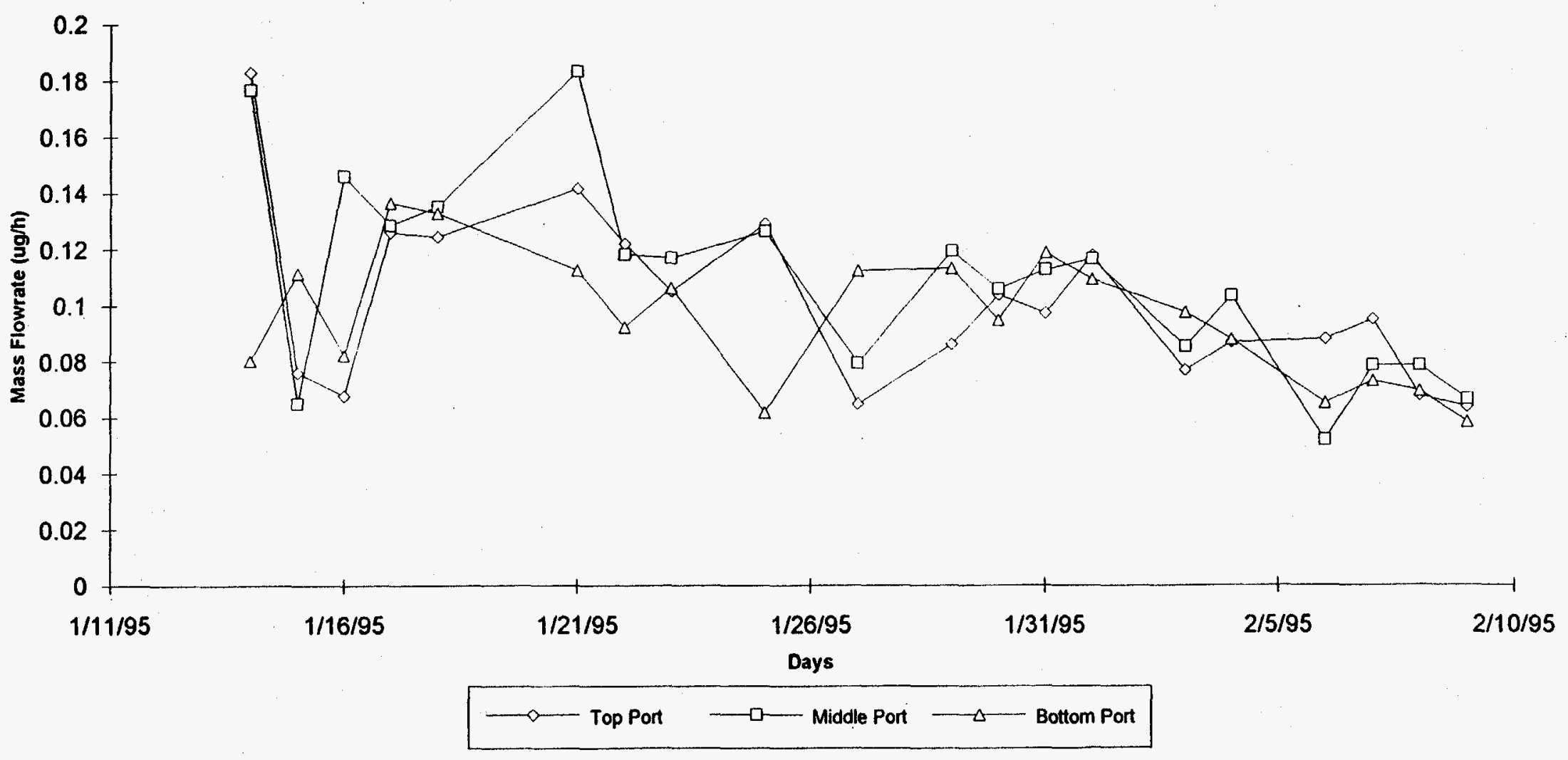




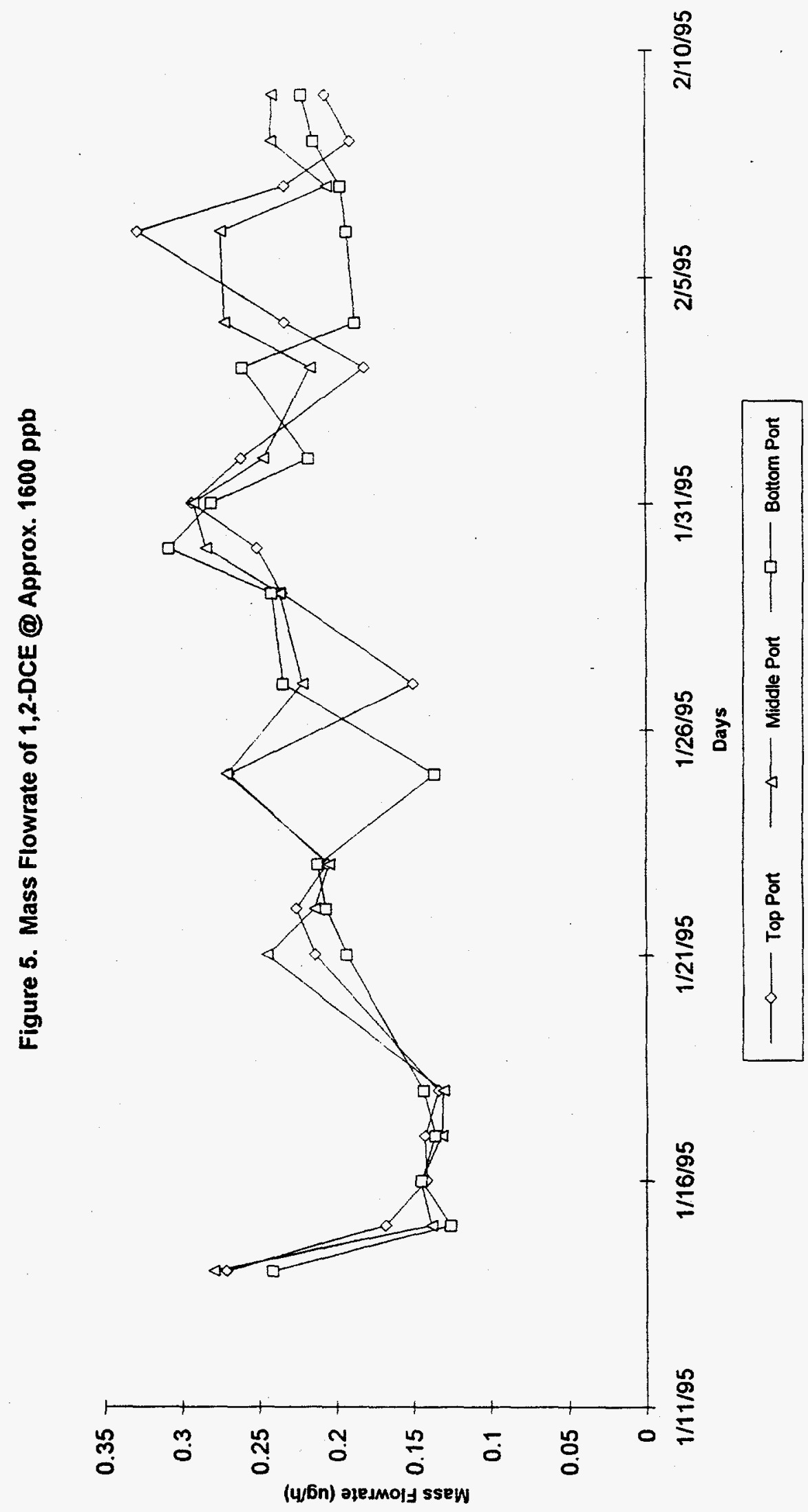




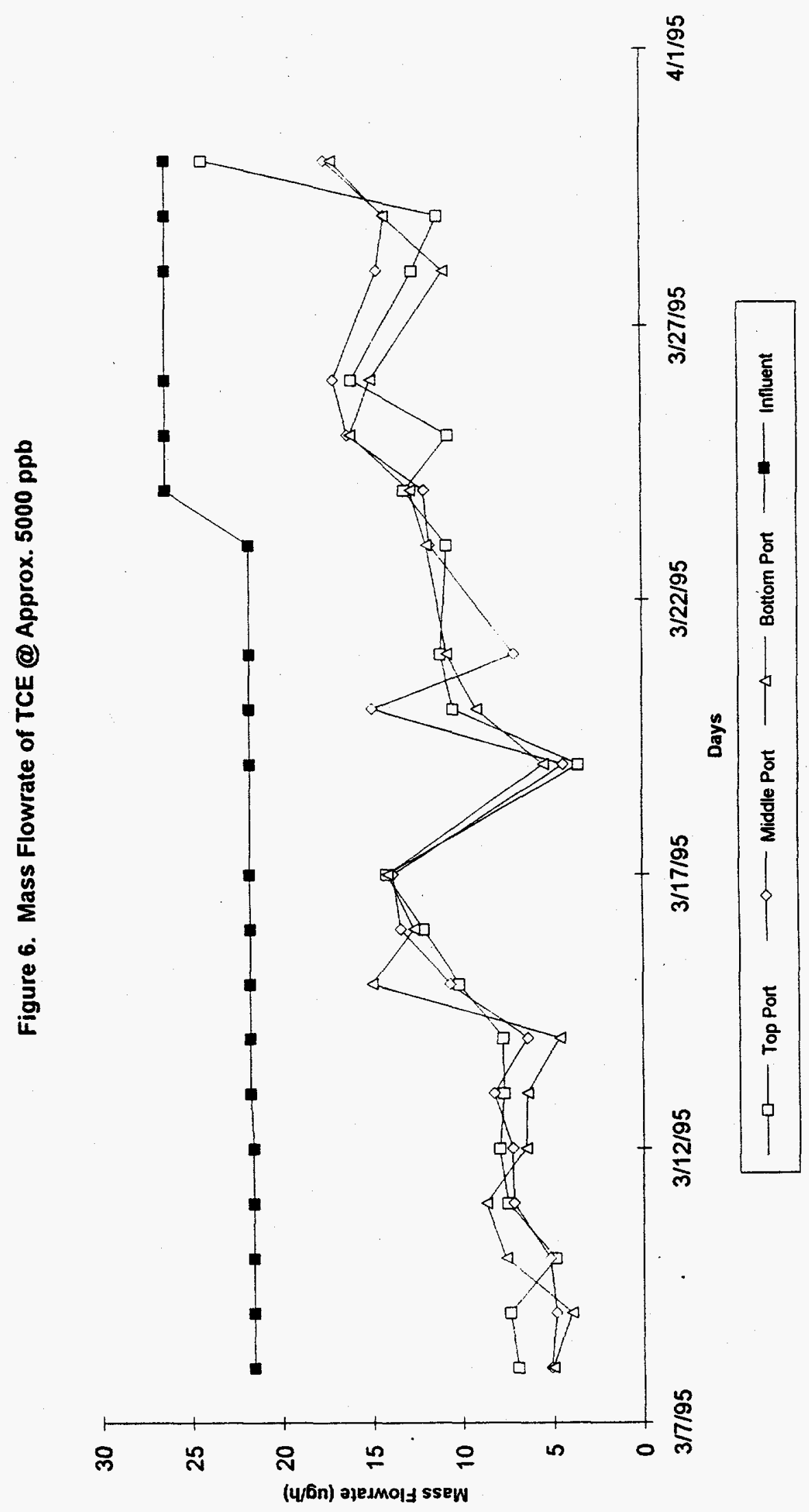




\section{○}

Figure 7. Mass Flowrate of TCE Removed in Top Port with Respect to Influent

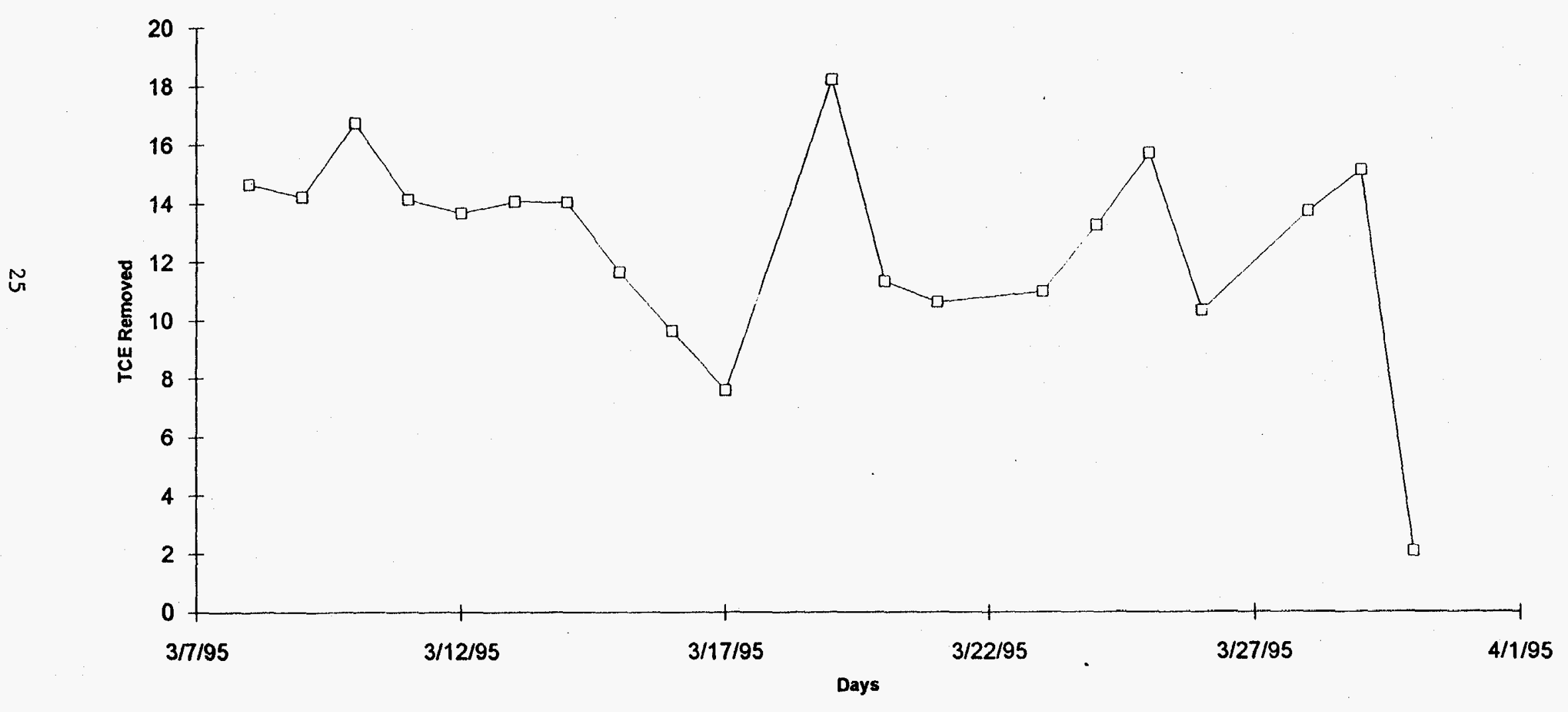




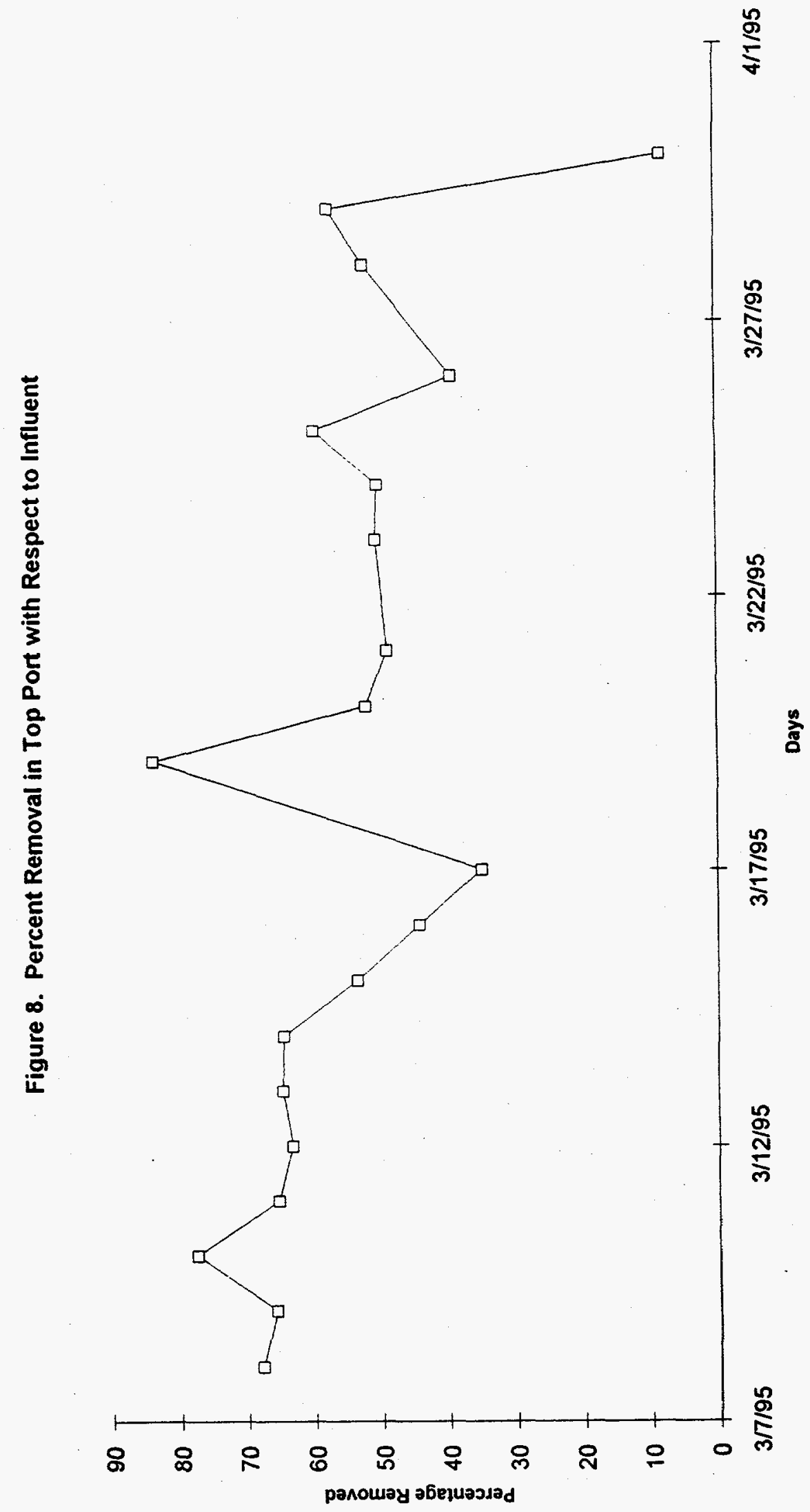




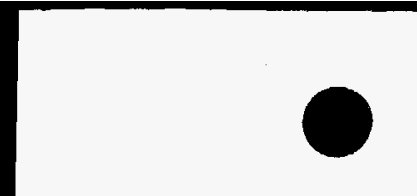

Figure 9. Mass Flowrate of 1,1-DCE @ Approx. 5000 ppb

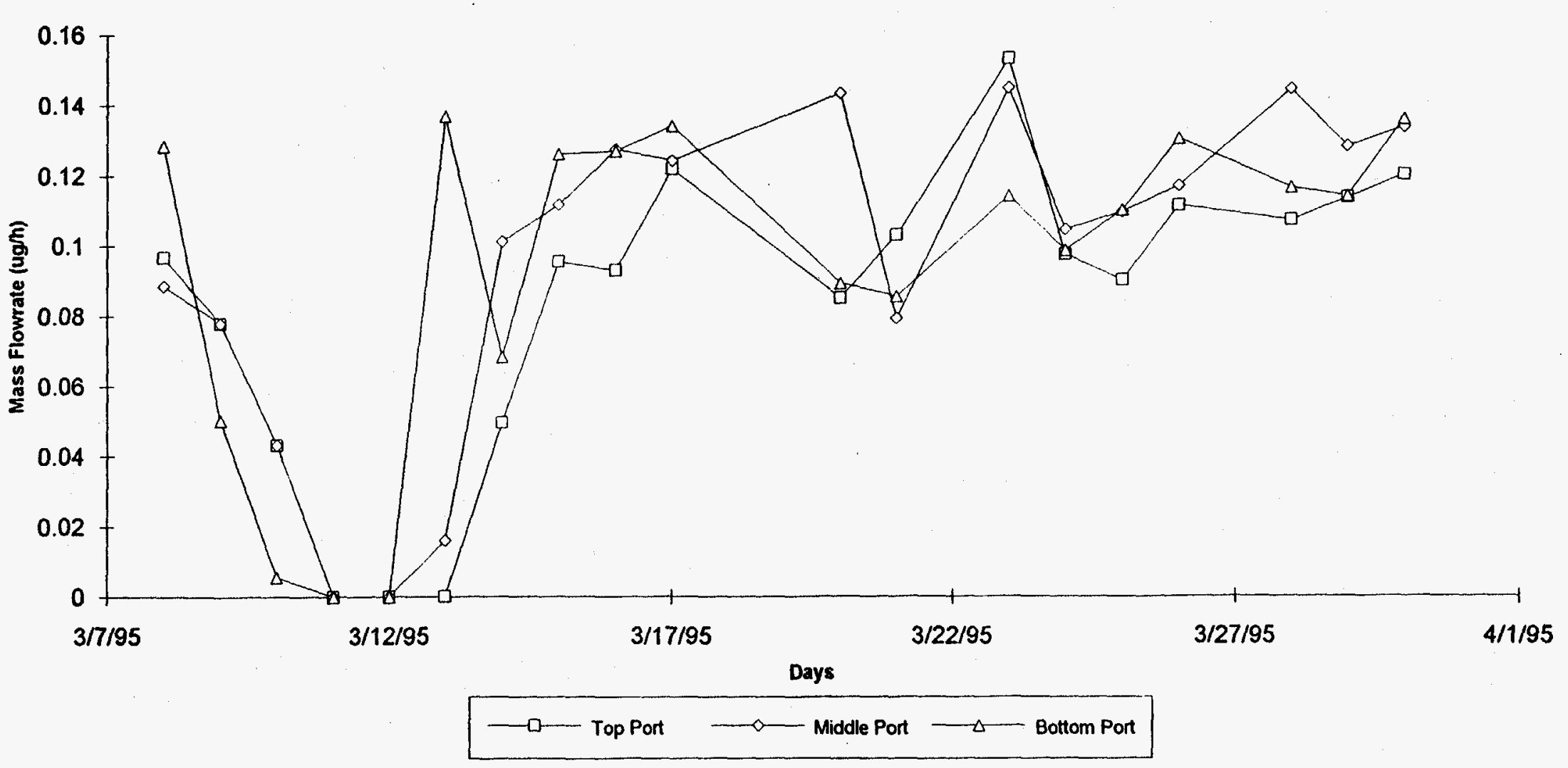




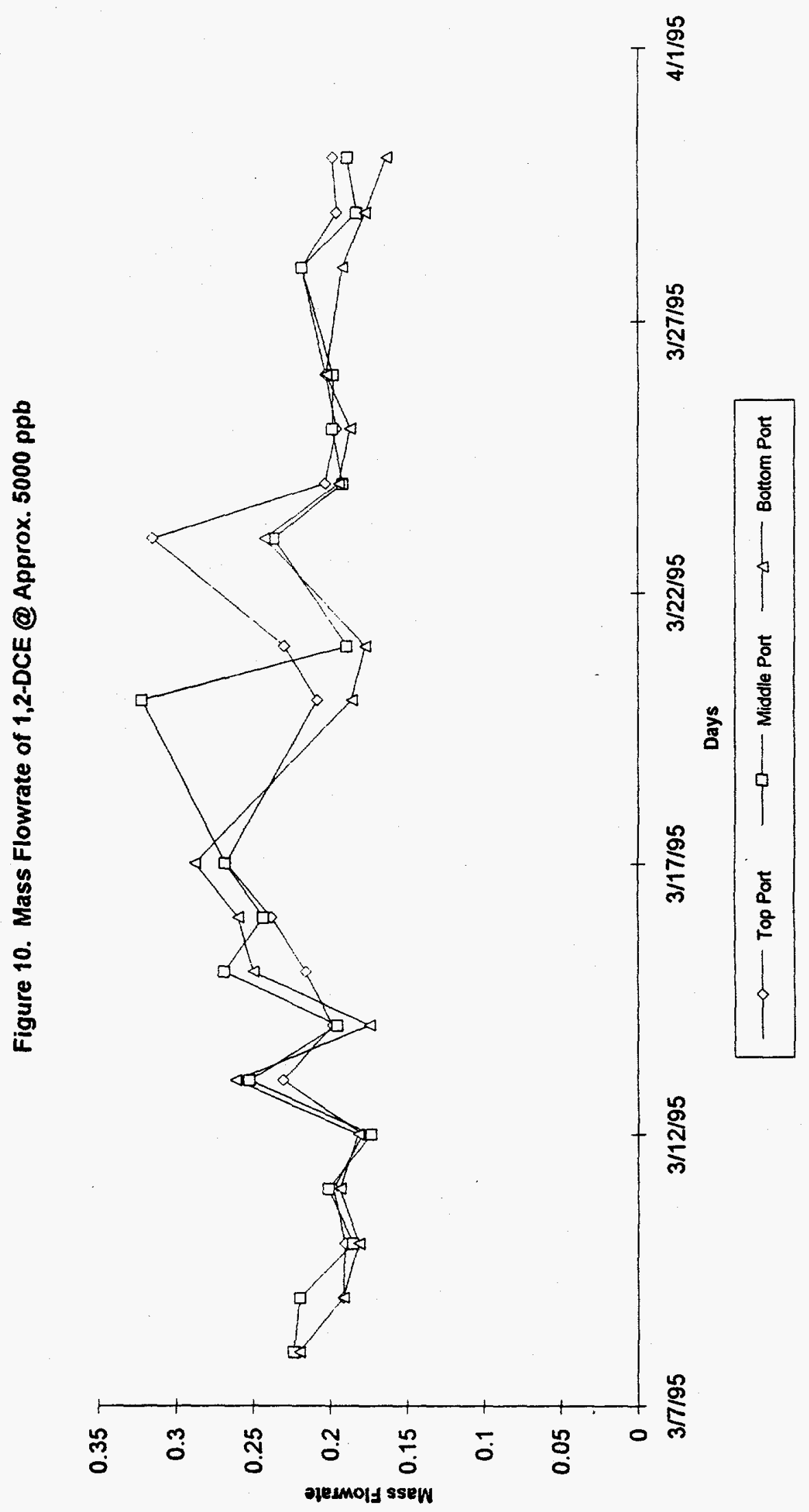


Figure 11. Concentration of TCE During shock Period

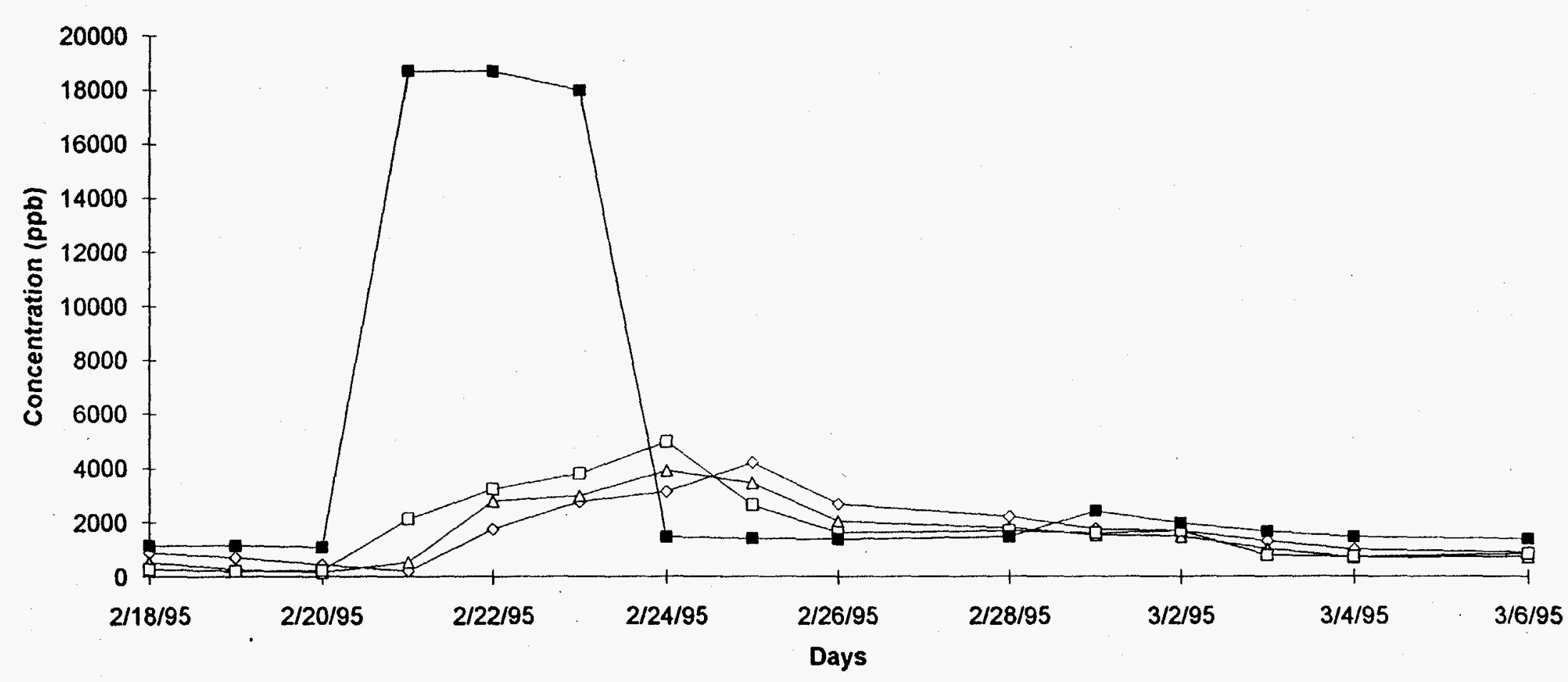

$$
\longrightarrow \text { Top Port } \longrightarrow \text { Middle Port } \longrightarrow \text { Bottom Port } \longrightarrow \text { Influent }
$$


Figure 12. Concentration in Bottom Port During Shock Period

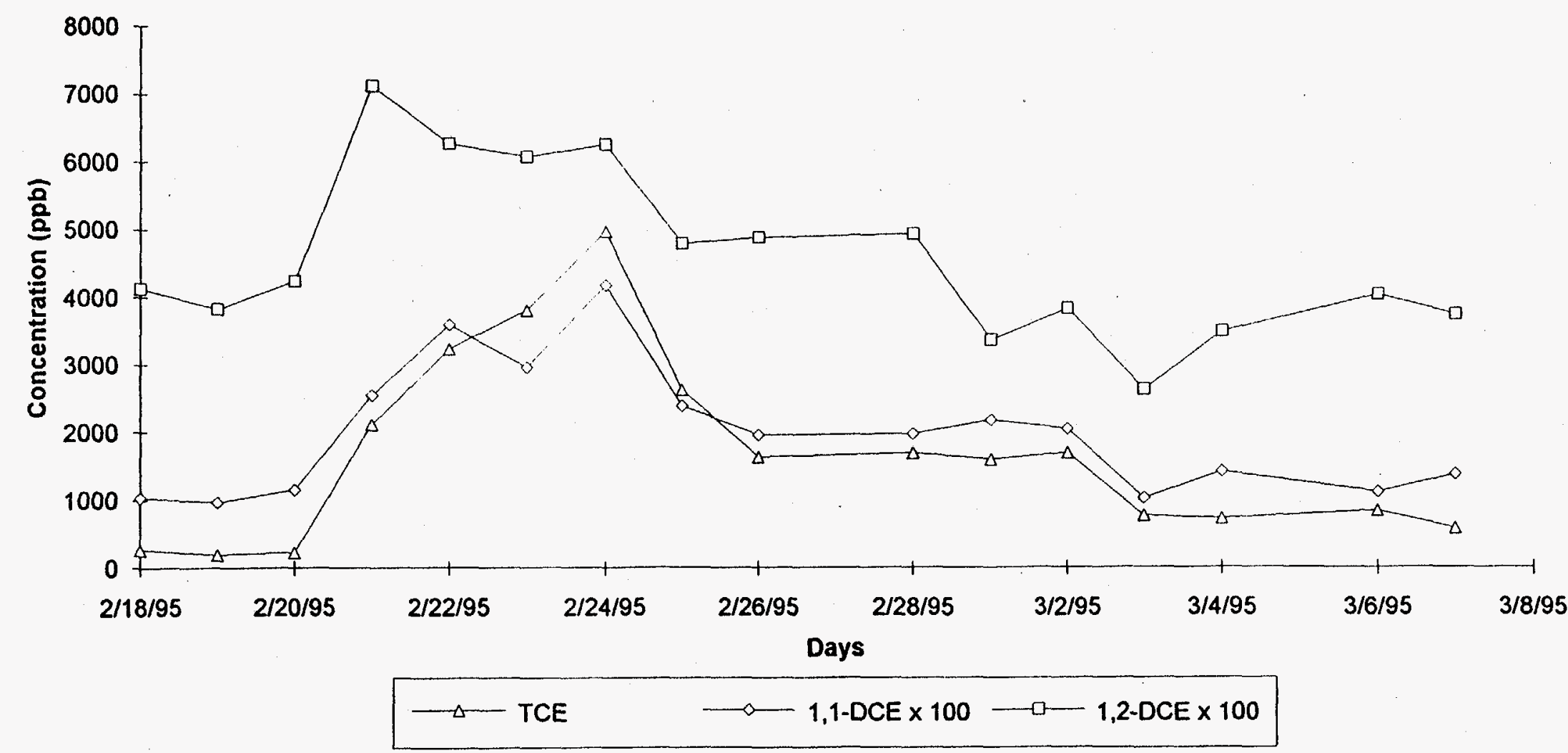




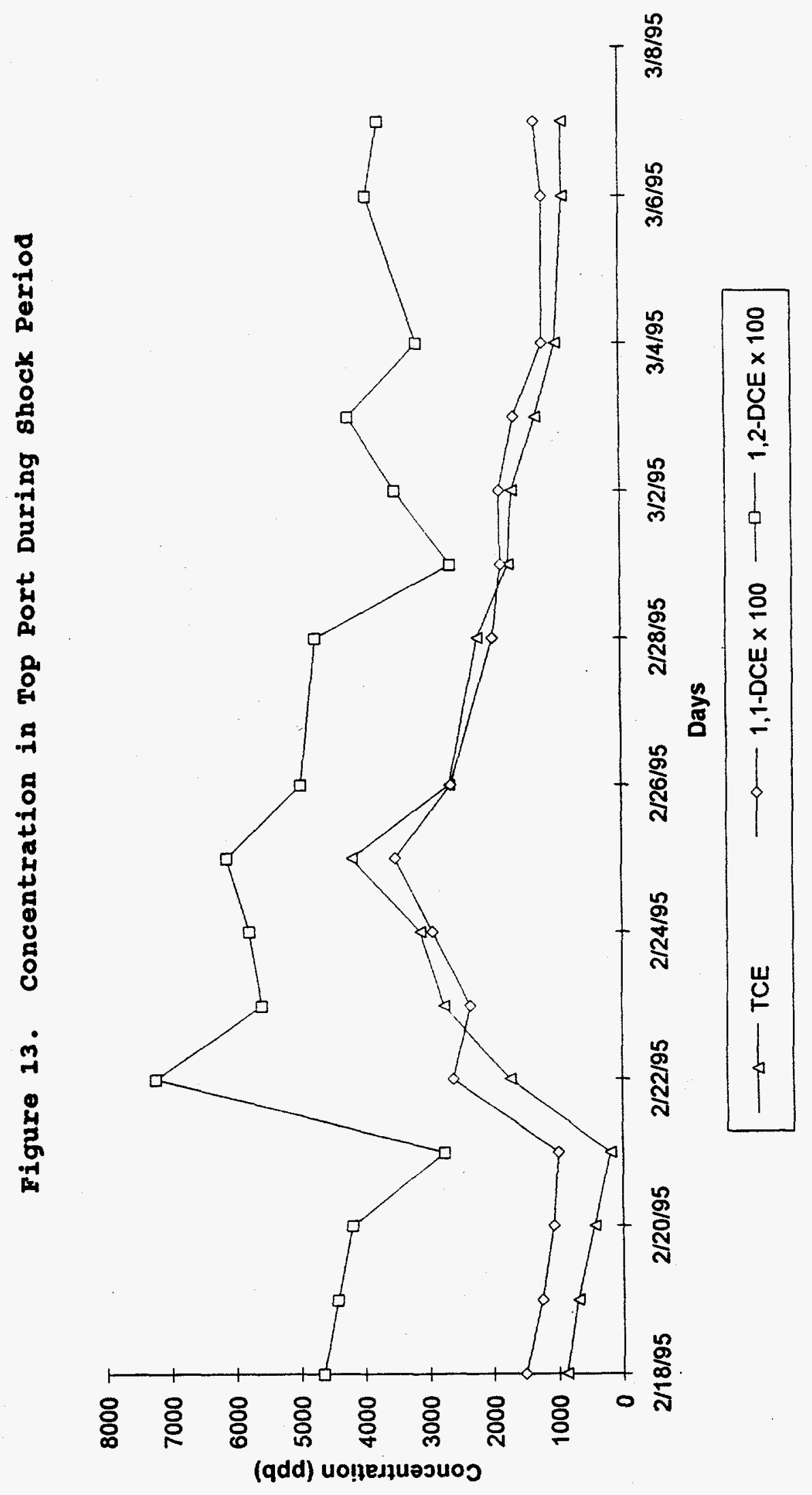

$-135-$ 
Figure 14. Top, middle and bottom port concentrations

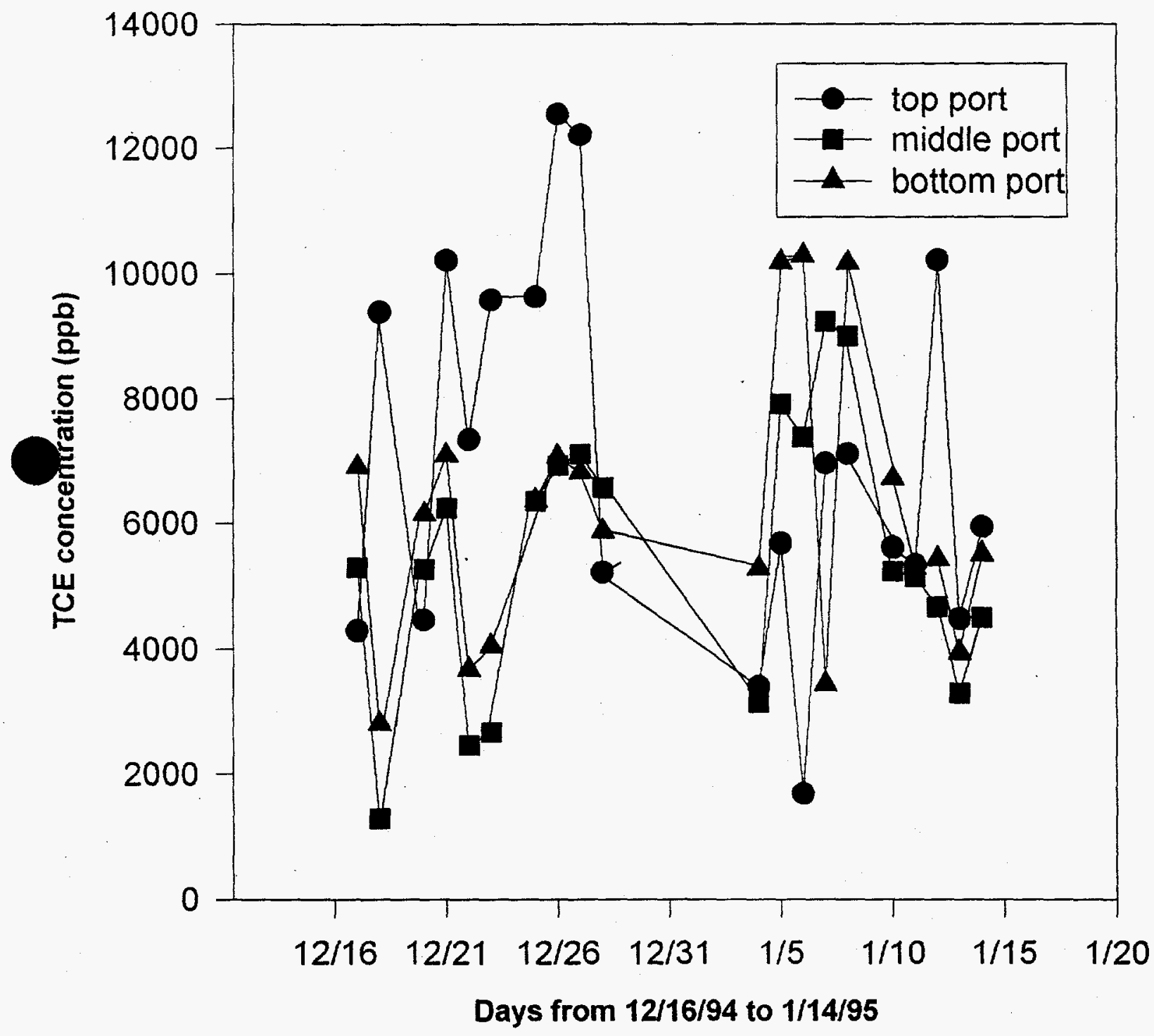


Figure 15. Overall percent removal of TCE

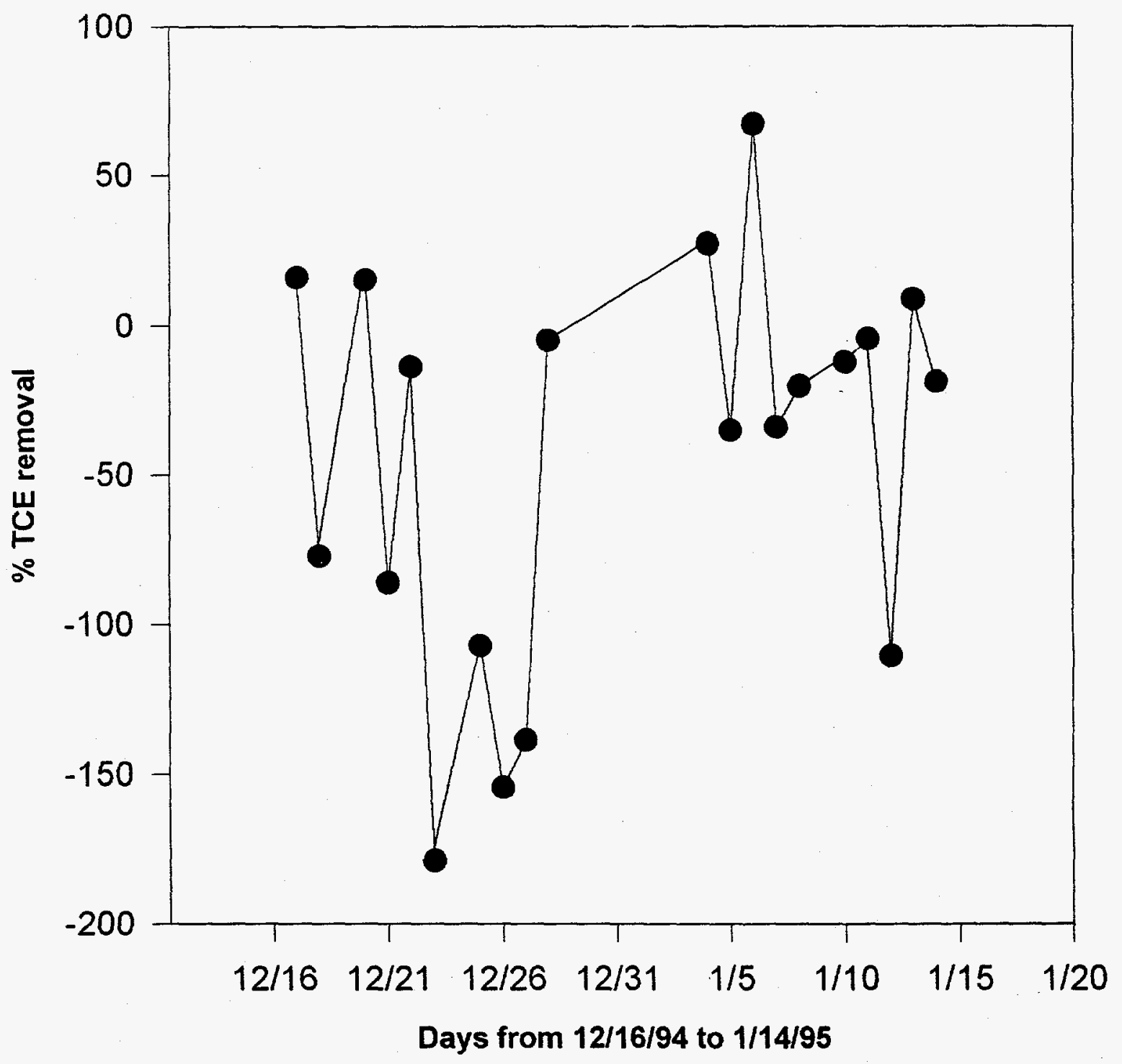




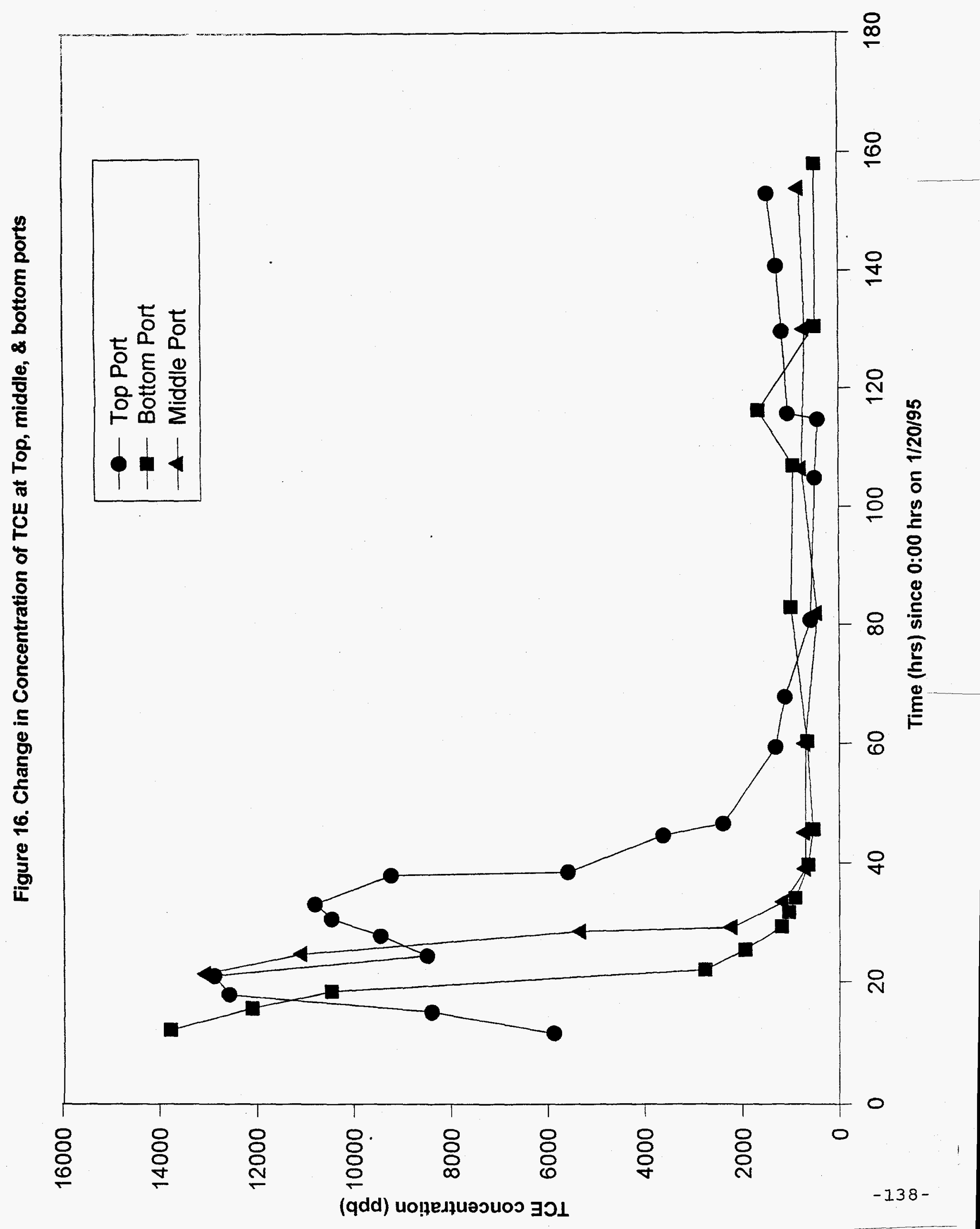


Figure 17. Top, middle, and bottom port concentrations

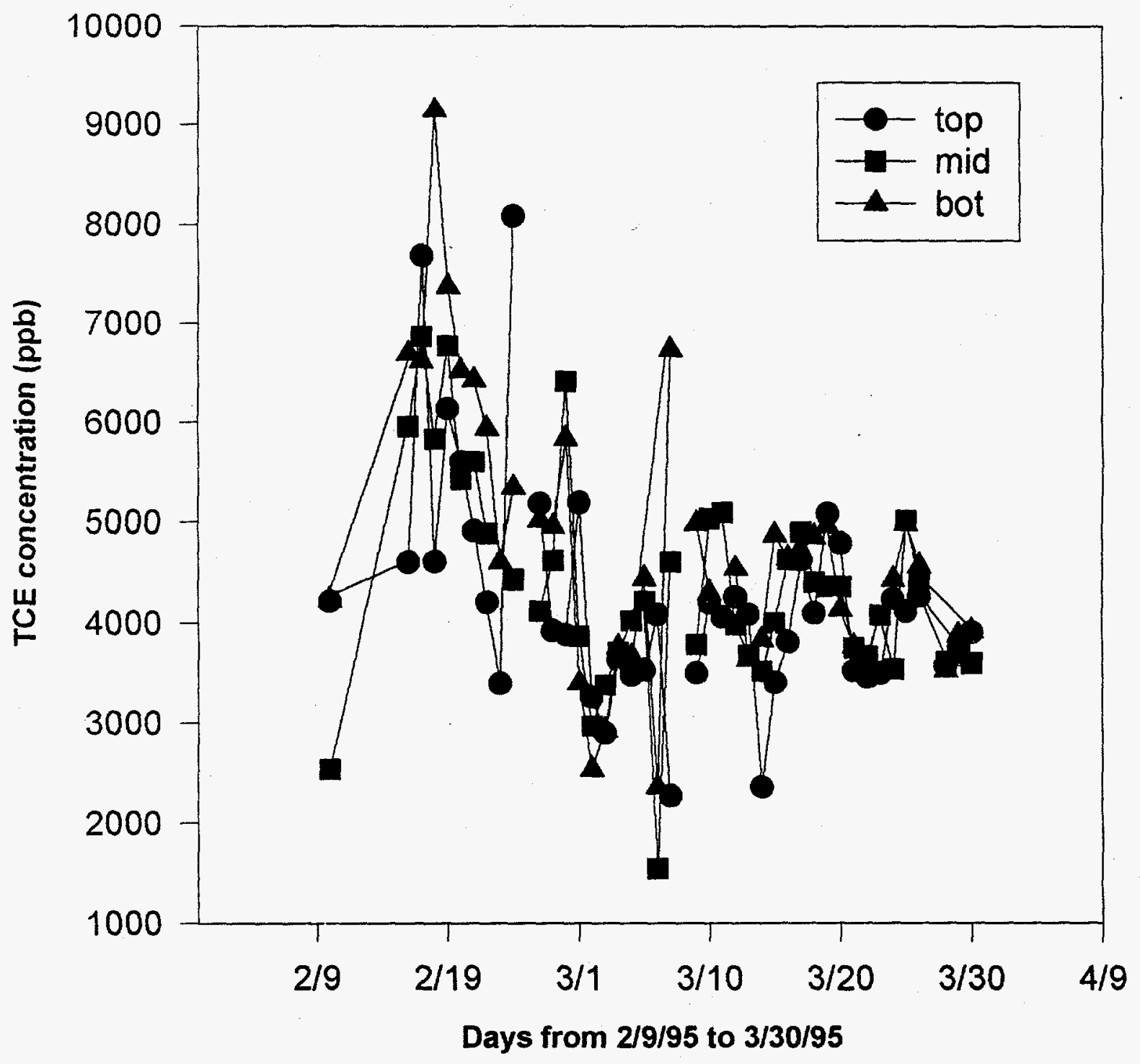


Figure 18. Overall TCE removal rate (ur /hr)

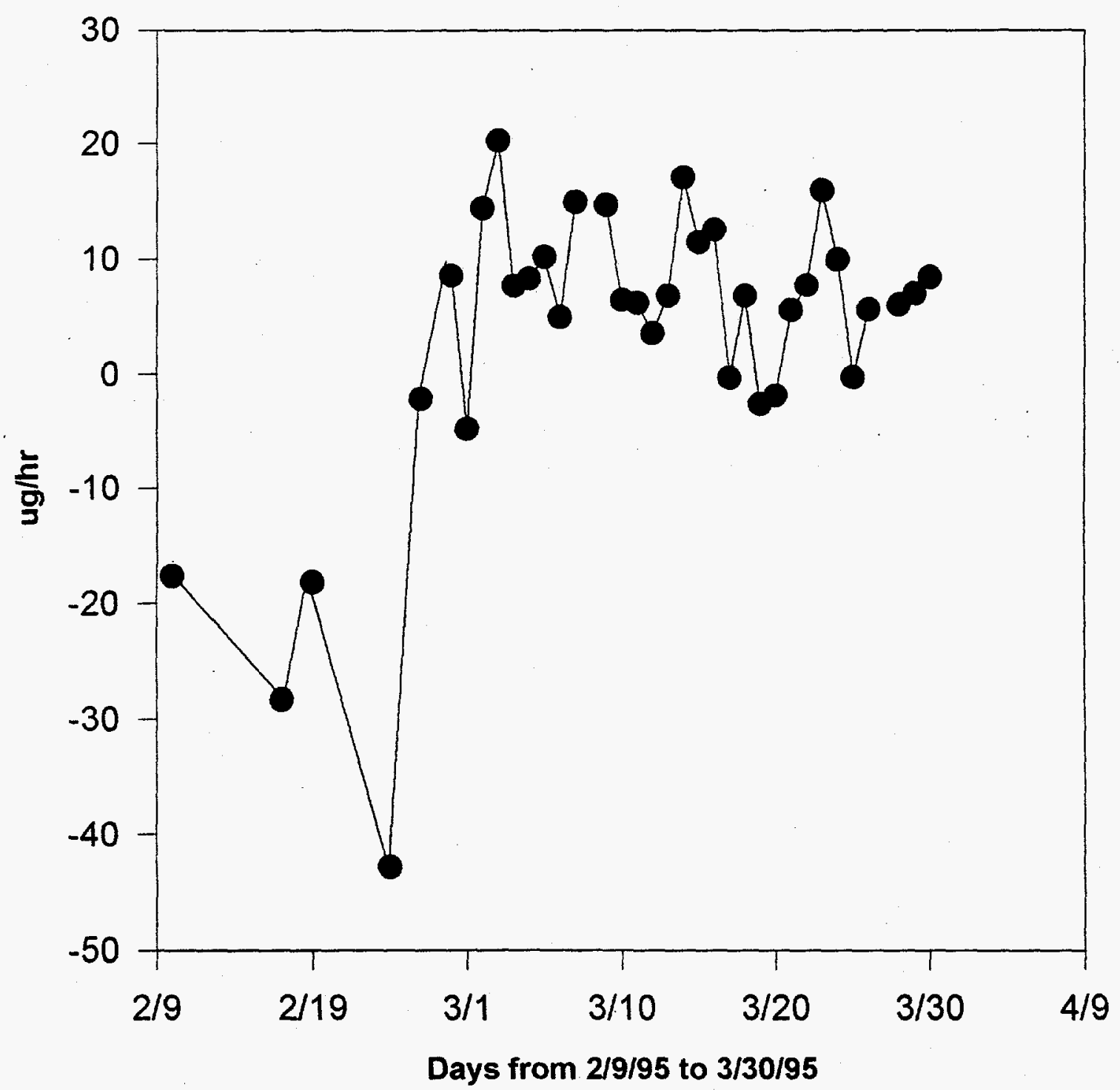

36

$-140-$ 
Figure 19. Overall percent removal of TCE

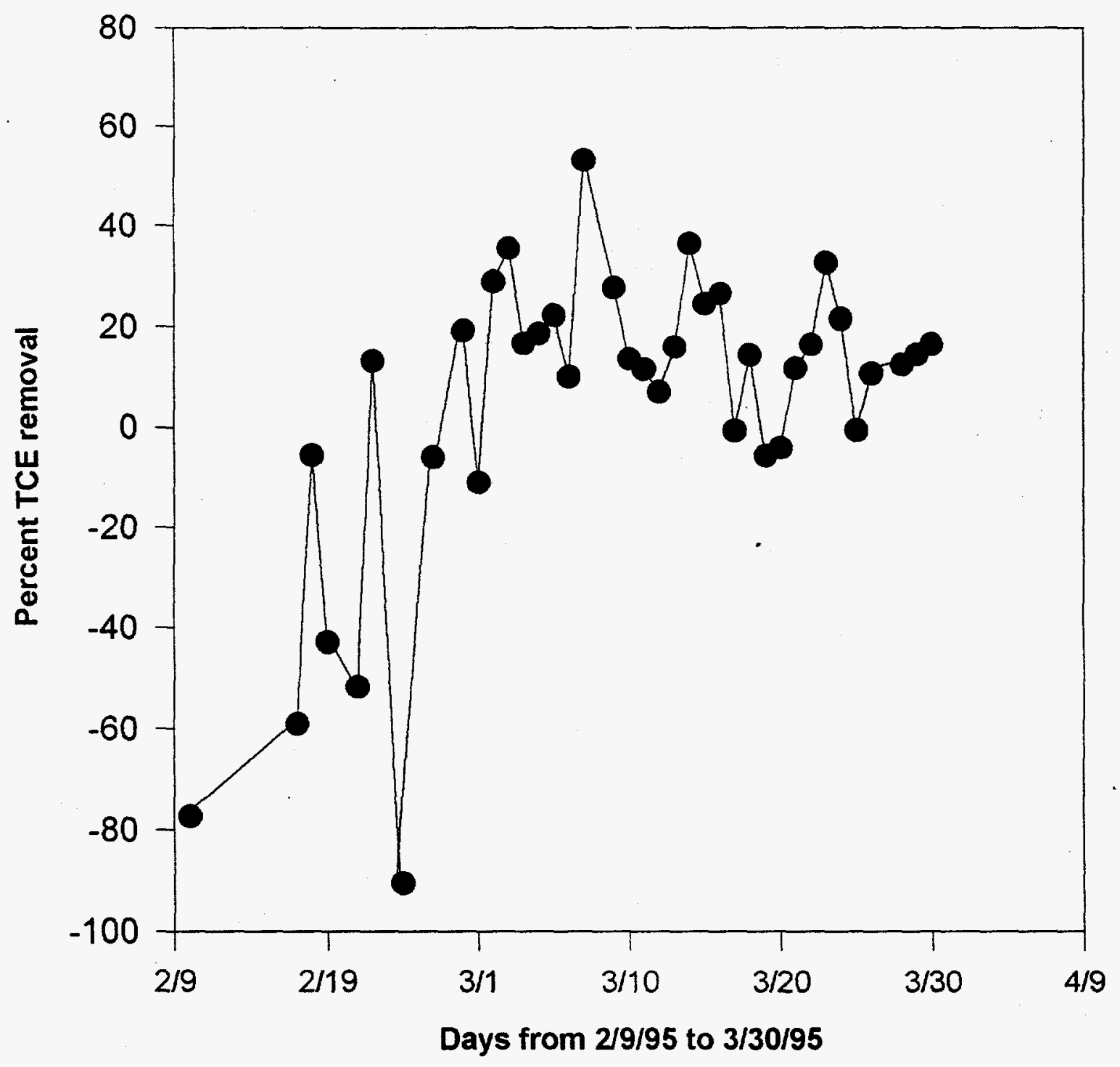


Figure 20. Changes in aerobic column conditions with time

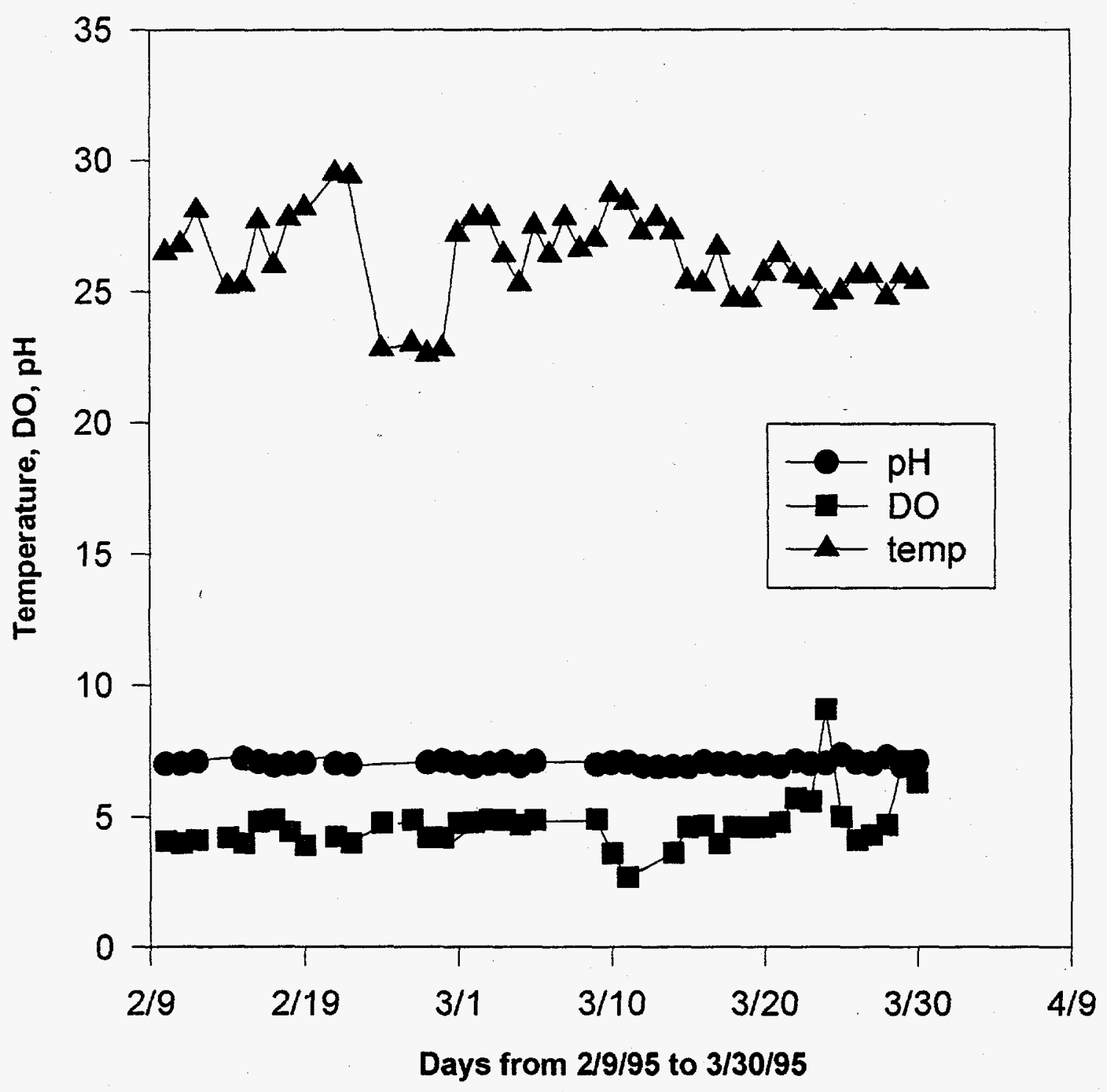


Microbial Enrichment for Enhancing In-Situ Biodegradation of Hazardous Organic Wastes in Soil

WVU / METC / DOE COOPERATIVE AGREEMENT

Contract No: DE-FC21-92NC29467

METC TASK No. 1.3

NRCCE Project MC-18

QUARTERLY REPORT: JANUARY-MARCH, 1995

For:

U.S. Department of Energy

Office of Fossil Energy

Morgantown Energy Technology Center

Morgantown, West Virginia

By:

Dr. Alan J. Sexstone and Dr. Pradeep Saini

Division of Plant \& Soil Sciences

College of Agriculture and Forestry

Dr. Chris Atkinson

Mechanical and Aerospace Engineering

College of Engineering

West Virginia University

Morgantown, WV 26506-6057 


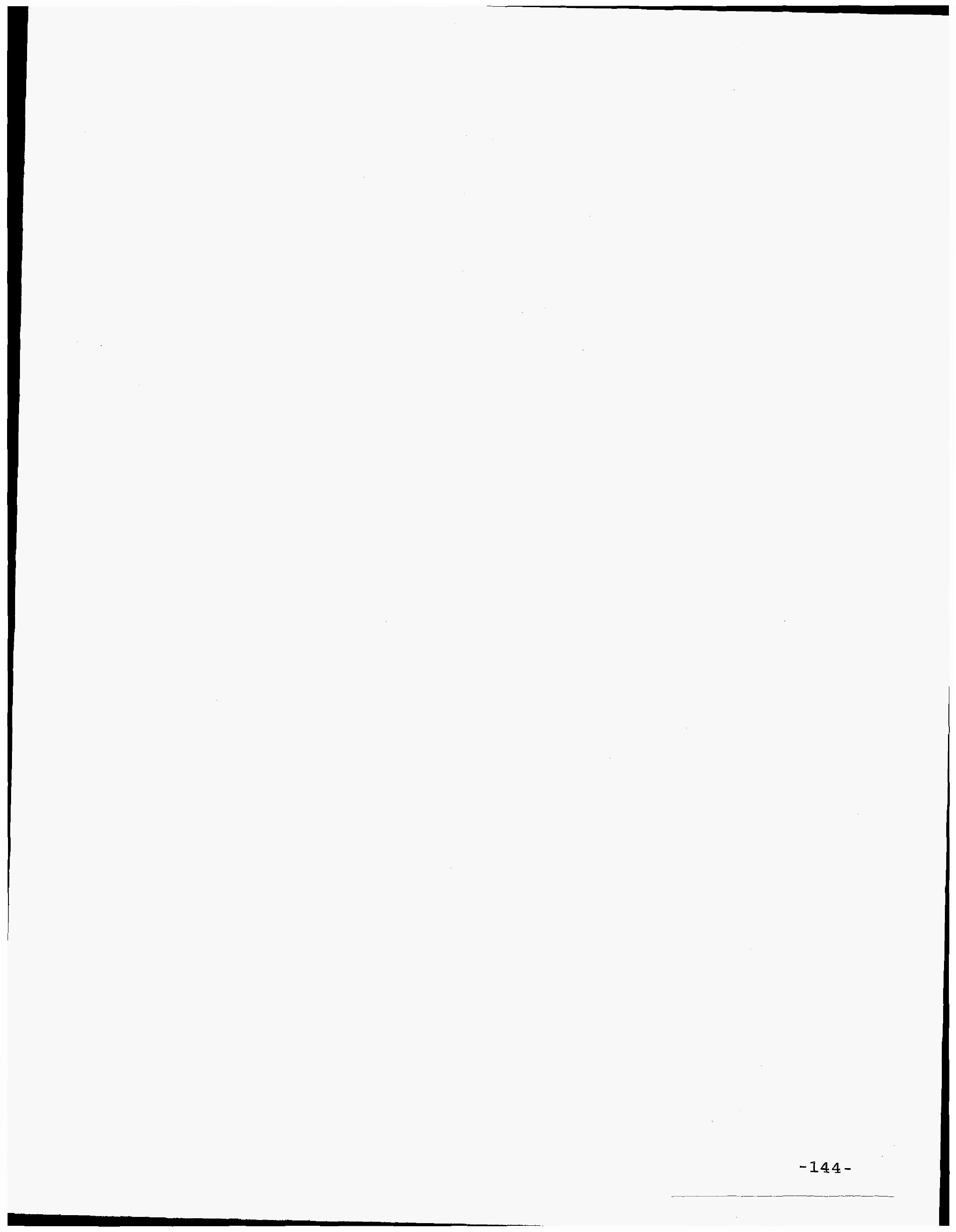

$-144-$

\section{$-144-$}




\section{INTRODUCTION AND PURPOSE}

Superfund and RCRA regulations have mandated the restoration of millions of cubic yards of contaminated soils nationwide. The cost of excavation and hauling large volumes of soil, combined with the tighter environmental regulation of landfills has severely restricted this cleanup option. Both industry and government are actively seeking additional innovative organic waste cleanup technologies to remedy this problem. Bioremediation is often proposed as a cost-effective treatment option for on-site hazardous waste clean-up, particularly where large soil volumes are involved and incineration is not considered feasible. However, biodegradation results are influenced by local site conditions making effective remediation difficult to predict and insure. We have been investigating the effectiveness of commercially available microbial inocula for use in bioaugmented remediation of hazardous mixed organic wastes in soil. At present, we are examining ex-situ remediation and surface composting, a process ideally suited to incorporation of a microbial inoculant. Bioaugmentation holds great promise for degradation of compounds which are now recalcitrant in soil, however efficacy of available microbial inocula must first be critically evaluated. We are developing a generalized testing procedure and expertise, which we can employ to examine bioaugmentation / biodegradation of a variety of wastes and / or waste sites.

Year 1 (1994) The purpose of the first year of study was to develop a reliable in vitro assay to directly compare selected commercially available microbial inocula for enhancing biodegradation of mixed organic wastes by soil composting. The products to be compared initially were taken from compilations provided by the EPA National Contingency Plan Product Schedule (NCPPS) or the EPRI Advanced Bioremediation Assessment and Technology Evaluation Program (ABATE). While both programs have identified microbial products, neither has directly compared efficacy of inoculation in soil composting. Inocula identified from the lists were obtained directly from the remediation firms which produce them and used in replicated laboratory experiments to determine treatment effects on the rate and extent of biodegradation and formation of characteristic degradation byproducts. The products were tested in both a surface and subsurface soil which have been excavated and amended for waste composting. Soils were contaminated with either a crude oil or model mixed waste containing hydrocarbons, solvents, and polynuclear aromatic hydrocarbons. Biodegradation of the pollutants was monitored in the presence and absence of inoculation. A specific objective of the work was to compare the efficacy of bioaugmentation in a surface and subsurface soil. The working hypothesis to be tested was whether positive effects of bioaugmentation are greatest in the subsurface soil due to reduced microbial competition in this environment. Results of the initial one year study generated specific comparisons of bioaugmentation products in a model test system.

Year 2 (1995) During the 1994 we concentrated on identification of superior commercially available microbial inocula for bioremediation of organic wastes. Inocula were screened for biodegradation kinetics in surface and subsurface soil samples artificially contaminated with a chemically defined model mixed organic waste. During the coming year we propose that superior products selected by our screening procedure must next be tested for effectiveness in the variety of mixed organic wastes and soils expected in real world conditions. Therefore, we will obtain soil samples from waste contaminated sites, 
return them to the laboratory, and quantify the effectiveness of selected inocula for bioaugmented soil remediation. We will assess effectiveness of biodegradation by monitoring substrate disappearance of parent organic compounds following their extraction from soil. To facilitate screening of a large number of soils we will also develop and apply a rapid radiorespirometric technique based on the ability of microorganisms to biodegrade ${ }^{14} \mathrm{C}$ labeled recalcitrant compounds directly injected into the mixed waste milieu of the contaminated sample. Identification of suitable inocula and development of rapid screening methods for waste biodegradation represent the next necessary step prior to large-scale deployment of bioaugmentation technology in the field.

\section{Objectives}

The overall research objective is delineation of conditions under which bioremediation can effectively be employed to enhance remediation of hazardous organic wastes. Specific objectives for the 1995 work are: 1)Verify the effectiveness of bioaugmentation in soils collected from sites previously contaminated with hazardous mixed organic wastes. Superior commercially available microbial inocula selected during our year one laboratory trials will be utilized. 2)Develop and apply a radiorespirometric technique for the rapid screening of bioaugmentation effectiveness in soil samples previously contaminated with hazardous mixed organic wastes.

\section{BACKGROUND AND METHODOLOGY}

Methodology of the 1994 study was extensively detailed in previous quarterly reports. The 1995 study will be performed by researchers in WVU's Division of Plant \& Soil Sciences. Contaminated soils for the study will be obtained from industrial and government sites identified by NRCCE as well as from existing production sites identified by regional oil and gas cooperatives with whom we cooperate (IOGA / WVONGA).. We will concentrate on soils contaminated with hydrocarbons and solvents and will study five sites.

Waste contaminated bulk soil will be returned to the laboratory and stored at $40 \mathrm{C}$ prior to use. Soils will be amended with $\mathrm{NH}_{4} \mathrm{NO}_{3}$ and $\mathrm{K}_{2} \mathrm{HPO} 4$ to fall within $\mathrm{C}: \mathrm{N}: \mathrm{P}: \mathrm{K}$ ratios determined as optimum for waste degradation. Soil samples ( $10 \mathrm{~g}$ wet weight) will be distributed to replicate $250-\mathrm{ml}$ Erlenmeyer flasks and adjusted to $25 \%$ gravimetric moisture content (approximately $60 \%$ water filled porosity, a level optimum for aerobic microbial activity in soil). Sterile control soils will be prepared by autoclaving flasks at $121{ }^{\circ} \mathrm{C}$ and $103 \mathrm{kPa}$ for 20 minutes on 2 consecutive days. The waste contaminated soil will be then mixed 1:1 with glass beads to improve porosity and aeration, a typical procedure for soil composting. Soils will also be amended with a water soluble dispersant chosen from the EPA NCPPS to enhance release of the waste from soil particles and maximize contact with the soil microflora. Half of the treated soils will be amended with the commercial microbial inocula at rates recommended by the manufacturer. Inocula selected are produced by Sybron, Interbio, and Hydrobac. Flasks will be capped with butyl rubber stoppers equipped with a rubber septa and incubated in the dark for 30 to 60 days. 
Each soil will be sampled on five dates by sacrificing four replicate flasks. Headspace gas of all flasks will be sampled weekly and analyzed for $\mathrm{CO}_{2}$ by gas chromatography (GC). Four flasks from each treatment group and two sterile controls will be sacrificed on day $0,7,28,42$, and 60 for solvent extraction of the waste. Headspace $\mathrm{CO} 2$ samples will be measured by GC using a Carle 100 gas chromatograph equipped with a thermal conductivity detector and a $2 \mathrm{~m}$ Poropak $\mathrm{Q}$ column. Solvent extracts will be analyzed by $\mathrm{GC}$ on a Varian 3400 gas chromatograph equipped with an autosampler, on column injector, and flame ionization detector. Separation of waste components will be achieved on a $30 \mathrm{~m}$ DB-1 capillary column. Some solvent extracts will also be analyzed by GC/MS.

Radiorespirometry will be employed to follow mineralization of individual compounds within the mixed waste. Individual $14 \mathrm{C}$ labeled compounds will be added to the contaminated soil at $0.9 \mathrm{uCi}$ per $10 \mathrm{gram}$ soil. The working assumption is that the added radiolabeled compound does not significantly increase the pool size of the component within the mixed waste, thus does not affect the mineralization rate of the compound. ${ }^{14} \mathrm{C}-\mathrm{CO}_{2}$ will be captured weekly by sparging into hyamine hydroxide and aliquots counted in a Scintiverse cocktail using a Wallac 1409 Scintillation counter. Direct injection of a known radiolabeled hydrocarbon or solvent into the mixed waste milieu of the soil should allow rapid assessment of relative biodegradation potential. If successfully developed, this technique will allow us to rapidly screen a larger number of soil samples for effectiveness of bioaugmentation.

Well equipped laboratories in Brooks Hall and the Agricultural Sciences Bldg are available for this study. They contain equipment necessary for the culture and maintenance of both aerobic and anaerobic microorganisms and for the chemical analyses of soil, sediments, and water. Major permanent analytical equipment includes: Super speed and Ultra centrifuges, a Coy anaerobic chamber, gas chromatographs (ECD,FID, TCD); HPLC ( UV/Vis, Conductivity, RI), a scintillation counter, an inductively coupled plasma emission spectrophotometer, atomic absorption spectrophotometers, a Dionex ion chromatograph, a Technichon autoanalyzer, and other routine laboratory equipment. We also have the full support of the NRCCE Analytical Facility.

\section{PROGRESS THIS PERIOD ( JANUARY - MARCH, 1995) RESULTS, DISCUSSION, CONCLUSIONS}

Using the Varian 3400 gas chromatography facility in Brooks Hall we completed final analyses of the over 1500 artificial mixed organic waste (AMOW) and crude oil samples generated in the 1994 study. Final reduction of these data were completed during the past quarter. Dr. Saini, a post-doctoral associate and our chief analyst, also has completed set-up of a Carle AGC gas chromatograph for the 1995 soil respiration analyses.

Commercial microbial inocula in use during the ongoing bioremediation trials are presented in Table 1. All inocula are multi-strain formulations immobilized onto bran or sand as a solid carrier. Sixty day experiments evaluating biodegradation of AMOW in soils augmented with these inocula are complete and reported (Figures $1-10$; Table 2). Both sterile and live soils exhibited similar half-lives for toluene and o-dichlorobenzene which abiotically volatilized 
rather than biodegraded under the conditions of the in vitro test procedure. These data emphasize the necessity for a valid sterile control soil in the determination of bioremediation potential. Inoculum addition decreased the half-life in surface soils of nonvolatile organic compounds. Waste Stream Technology's Bioblend formulations appeared to be particularly effective, however the biodegradation data resulting from addition of these lyophilized sand cultures were not well described by first-order kinetics resulting in poor half-life estimates. We are at present trying to determine if the observed biodegradation rate estimates are valid, or are an artifact of the inoculum carrier. Other inocula were formulated on oat bran carriers and biodegradation results with these inocula were well described by first-order kinetics. The data indicate that Sybron Chemical's ABR formula consistently decreased compound half-lives in comparison to those observed in uninoculated soil. Beneficial results appeared to be most pronounced in subsurface compared with surface soils (Table 2). We also performed trials utilizing a light W.V. crude oil in place of AMOW. Half-lives of 6 n-alkanes (tetradecane, hexadecane, heptadecane, octadecane, nonadecane, and docosane) and two iso-alkanes (pristane and phytane) were determined by regression analysis (Figures 13-20). Three inocula (Sybron, Interbio, Hydrobac) significantly decreased half-lives of these hydrocarbons in soil (Table 3,4). Microbiological analysis demonstrated that these inocula contained the highest number of hydrocarbon degrading bacteria (Table 5).

The effect of nutrient amendment on bioremediation the absence of bioaugmentation was also examined (Table 6-7) Levels of $\mathrm{N}$ significantly increased biodegradation of individual hydrocarbon compounds, but $\mathrm{P}$ amendment had no significant effect. Plots amended with lower $N$ levels ( $C: N$ 60:1 and 120:1) exhibited significantly higher biodegradation rates than plots receiving high $N(C: N=30: 1)$ or zero $N$. In general, biodegradation rates decreased with increasing molecular weight of the individual hydrocarbon, and n-alkanes biodegraded faster than corresponding iso-alkanes. Similar results were obtained with higher oil application rates $(10 \% \mathrm{w} / \mathrm{w}$ compared with $2.4 \% \mathrm{w} / \mathrm{w})$. The residual saturation capacity of the Guernsey silt loam was determined to be $7.05 \mathrm{~L} \mathrm{oil} \mathrm{m} \mathrm{m}^{-2}(5 \% \mathrm{w} / \mathrm{w})$ at field moisture capacity. Increasing soil moisture content decreased the residual saturation capacity of the soil for oil.

During the past quarter we began the preliminary work on our 1995 objectives. We have monitored cumulative AMOW mineralization in the presence and absence of inocula ( Figure 11-12 ). Inoculum addition significantly increases soil respiration compared with uninoculated soil and soil amended with sterile inocula. Addition of waste to inoculated soil inhibits soil respiration compared to non-waste amended soil. We are now obtaining $14 \mathrm{C}$ labeled substrates to develop the radiorespirometric assay of specific organic pollutants.

\section{WORK PLANNED FOR NEXT PERIOD}

During the coming quarter we will prepare a completion report on our 1994 work (see milestones below) and continue our 1995 work by development of the radiorespirometric assay, identify field sites, begin site characterizations, and bioremediation trials as discussed in our 1995 milestones chart (see below and attached). 
(9.0) DIFFICULTIES: Funds arrived in March, delaying start-up of 1995 research.

\begin{tabular}{|c|c|c|c|c|}
\hline \multicolumn{5}{|c|}{ Percentage of Project Completion, MC-18, Year 1 (1994) } \\
\hline Task \# & WBS Code & Task Name & Dura & \% Complete \\
\hline 2 & 1.1 & Research Bioremediation & 6w & 100 \\
\hline 3 & 1.2 & Technology Evaluation & $7 w$ & 100 \\
\hline 6 & 3.1 & Hire post-doctoral & 6w & 100 \\
\hline 7 & 3.2 & Characterize soil & $3 \mathbf{w}$ & 100 \\
\hline 8 & 3.3 & Soil analysis & $3 \mathbf{w}$ & 100 \\
\hline 9 & 3.4 & Obtain HCs & $4 w$ & 100 \\
\hline 10 & 3.5 & Extraction techniques $18 \mathrm{w}$ & & \\
\hline 11 & 3.6 & Obtain inocula & & \\
\hline 12 & 3.7 & Finalize QAVC & $8 w$ & 100 \\
\hline 13 & Biore & mediation Trial 1 & $14 w$ & 100 \\
\hline 14 & Biore & mediation Trial 2 & $14 w$ & 100 \\
\hline 15 & Trial & Repeats (concurrent) & $19 w$ & 100 \\
\hline 17 & 7.1 & Analysis \& Data Reduction & $4 w$ & 100 \\
\hline 18 & 7.2 & Reports \& Manuscripts & $4 w$ & 50 \\
\hline 19 & Closu & & & 0 \\
\hline 20 & Over & Il Work Complete & & 0 \\
\hline
\end{tabular}

Percentage of Project Completion, MC-18, METC Task 1.3, Year 2 (1995)

1.0

2.0

2.1

2.2

3.0

3.1

3.2

3.3

3.4

4.0

4.1

4.2

4.3

4.4

4.5

5.0

6.0

6.1

6.2

7.0
Preliminary Research

Analytical Techniques

Evaluate Radiorespirometry

Develop Radiorespirometric Assay

Preparation of Trials

Site Identification

Site Characterization

Waste Characterization

Finalize QA/QC

Bioremediation Trials

Trial 1

Trial 2

Trial 3

Trial 4

Trial 5

Trial Repeats (concurrent)

Analysis and Reporting

Analysis and Data Reduction

Reports and Manuscripts

Overall Work Complete
$8 w$

75

$8 w$

10

10

$12 \mathrm{w}$

$12 w$

$12 \mathrm{w}$

$8 w$

$6 \mathrm{w}$

$6 \mathrm{w}$

$6 w$

$6 w$

6w

\section{5}

0

0

0

$8 w \quad 2$

$40 \mathrm{w} \quad 0$

$50 \mathrm{w} \quad 0$ 
Table 1. Commercial microbial inocula used for bioaugmentation study.

Inoculum Source

Enviroflow, Inc.

12181 Balls Ford Road

Manassas, Va 22110

International Biochemicals Group

Microbe Masters, Inc.

P.O. Box 45212-210, Baton Rouge, LA 70895

Polybac Corporation

3894 Courtney Street

Bethlehem, PA 18017

Sybron Chemicals, Inc.

111 Kesler Mill Road

Salem, VA 24153

Waste Stream Technology

302 Grote Street

Buffalo, NY 14207
Product Designation

DBC Plus, Type R5

Dried Bacterial Cultures

Micro Pro "SSC"

Dried Bacterial Cultures

Hydrobac

Dried Bacterial Cultures

ABR Hydrocarbon (9583)

Dried Bacterial Cultures

Bioblend M-B4W

Bioblend M5

Dried Bacterial Cultures

Table 2. Calculated half life ( $\mathrm{t}_{12}$, days) of individual components of mixed organic waste as affected by inoculation.

\begin{tabular}{|c|c|c|c|c|c|c|}
\hline \multirow[b]{2}{*}{ Treatment } & \multicolumn{2}{|c|}{ Naphthalene } & \multicolumn{2}{|c|}{ Heptadecane } & \multicolumn{2}{|c|}{ Pristane } \\
\hline & Surface & Subsurface & Surface & Subsurface & Surface & Subsurface \\
\hline $\mathrm{SS}+\mathrm{SI}+\mathrm{NN}$ & 100.9 & 109.7 & 471.4 & 376.6 & 455.9 & 368.6 \\
\hline $\mathrm{S}+\mathrm{SI}+\mathrm{N}$ & 30.1 & 28.9 & 19.3 & 23.1 & 30.1 & 27.7 \\
\hline M-B4W & 19.8 & 18.2 & 6.6 & 9.5 & 7.0 & 11.2 \\
\hline M5 & 16.1 & 15.1 & 5.5 & 5.9 & 5.6 & 6.4 \\
\hline DBC Plus R5 & 34.7 & 27.7 & 19.3 & 21.0 & 23.9 & 23.9 \\
\hline Hydrobac & 33.0 & 31.5 & 27.7 & 20.4 & 34.7 & 25.7 \\
\hline Interbio SSC & 31.5 & 33.0 & 14.4 & 14.4 & 27.7 & 27.7 \\
\hline ABR HC & 23.1 & 12.4 & 8.6 & 7.8 & 23.1 & 19.8 \\
\hline
\end{tabular}

SS $=$ Sterilized soil

$\mathrm{SI}=$ Sterilized inoculum

$\mathrm{NN}=$ No nutrients 
Table 3. Percent remaining of hydrocarbon compounds following a 60 day growth chamber incubation in the bioaugmentation experiment.

\begin{tabular}{|c|c|c|c|c|c|c|c|}
\hline \multirow{3}{*}{ Compound Inocula } & \multirow[b]{2}{*}{$\mathrm{DBC}$} & \multicolumn{5}{|c|}{ Day 60} & \multirow[b]{2}{*}{ Soil } \\
\hline & & Hydrobac & Interbio & Sybron & M-B4W & M5 & \\
\hline & \multicolumn{7}{|c|}{ Compound } \\
\hline decane $C_{10}$ & $<1$ & $<1$ & $<1$ & $<1$ & $<1$ & $<1$ & $<1$ \\
\hline undecane $C_{11}$ & $<1$ & $<1$ & $<1$ & $<1$ & 1.2 & $<1$ & $<1$ \\
\hline dodecane $\mathrm{C}_{12}$ & $<1$ & $<1$ & $<1$ & $<1$ & $<1$ & $<1$ & $<1$ \\
\hline tridecane $C_{13}$ & 1.1 & $<1$ & 1.1 & 1.3 & 6.3 & 4.8 & 1.2 \\
\hline tetradecane $C_{14}$ & 4.4 & 2.5 & 3.8 & 3.4 & 18.8 & 11.6 & 5.2 \\
\hline pentadecane $C_{15}$ & 2.4 & 2.2 & 3.2 & 3.4 & 16.1 & 13.5 & 4.1 \\
\hline hexadecane $C_{16}$ & 4.1 & 5.7 & 6.2 & 7.3 & 22.0 & 17.0 & 7.5 \\
\hline heptadecane $C_{17}$ & 4.4 & 3.1 & 5.5 & 4.6 & 21.6 & 12.9 & 4.3 \\
\hline octadecane $C_{18}$ & 8.5 & 5.1 & 5.5 & 6.5 & 20.7 & 18.4 & 5.6 \\
\hline nonadecane $\mathrm{C}_{19}$ & 12.2 & 8.9 & 9.8 & 8.3 & 30.5 & 27.7 & 9.4 \\
\hline eicosane $C_{20}$ & 5.7 & 2.7 & 4.0 & 4.0 & 19.5 & 13.6 & 4.5 \\
\hline heneicosane $C_{21}$ & 7.1 & 8.3 & 4.4 & 4.6 & 12.3 & 9.7 & 9.9 \\
\hline docosane $C_{22}$ & 4.8 & 3.3 & 3.0 & 3.3 & 11.8 & 7.8 & 5.8 \\
\hline tricosane $\mathrm{C}_{23}$ & 5.0 & 4.0 & 3.4 & 3.5 & 10.5 & 6.4 & 5.0 \\
\hline tetracosane $C_{24}$ & 7.4 & 7.3 & 9.5 & 10.3 & 15.1 & 7.8 & 4.8 \\
\hline pentacosane $C_{25}$ & 9.3 & 7.4 & 7.9 & 7.8 & 17.9 & 12.3 & 9.3 \\
\hline hexacosane $C_{26}$ & 9.2 & 6.6 & 10.8 & 9.0 & 8.8 & 5.9 & 4.2 \\
\hline octacosane $C_{28}$ & 24.9 & 34.0 & 23.3 & 28.6 & 35.9 & 27.0 & 19.4 \\
\hline pristane $_{17}$ & 33.6 & 21.0 & 24.3 & 17.9 & 58.6 & 43.1 & 17.0 \\
\hline phytane $C_{20}$ & 34.7 & 19.6 & 19.9 & 19.8 & 54.3 & 51.1 & 18.1 \\
\hline
\end{tabular}


Table 5. Total heterotrophic plate counts and oil degrader counts enumerable in inoculated oil contaminated soil following a $\mathbf{3 0}$ day growth chamber incubation

\begin{tabular}{|c|c|c|c|c|}
\hline & $\begin{array}{c}\text { Total Heterotrophs } \\
\text { TSA } \\
\end{array}$ & $\begin{array}{c}\text { Oil Degraders } \\
\text { (BH* oil-BH no oil) }\end{array}$ & $\mathrm{BH}+1 \%$ Oil & $\mathrm{BH}+0 \% \mathrm{Oil}$ \\
\hline Surface Soil ${ }^{5}$ & 6.98 & 7.97 & 8.03 & 7.18 \\
\hline Subsurface Soil ${ }^{s}$ & 6.23 & 4.60 & 6.78 & 6.32 \\
\hline Interbio & 11.19 & 9.98 & 10.06 & 9.24 \\
\hline DBC Plus R5 & 10.96 & 9.95 & 9.99 & 8.96 \\
\hline Syborn & 10.74 & 9.10 & 9.25 & 8.70 \\
\hline MB4W & 10.91 & 8.85 & 8.87 & 7.59 \\
\hline M5 & 5.81 & 8.99 & 9.03 & 7.96 \\
\hline Hydrobac & 10.35 & 10.12 & 10.17 & 9.23 \\
\hline $\operatorname{LSD}^{\#}(0.05)$ & 0.21 & 2.44 & 0.26 & 0.11 \\
\hline
\end{tabular}

- Difco Bushnell Haas mineral salts medium.

"Least significant difference.

${ }^{s}$ Guernsy silt loam soil A horizon $(0-7.5 \mathrm{~cm})$ and $\mathrm{C}$ horizon $(>45 \mathrm{~cm})$. 
Table 6. Percent remaining of hydrocarbon compounds following a 90 day field incubation.

\begin{tabular}{lllll}
\hline \multicolumn{1}{c}{ Nitrogen Treatment (C:N) } & no N & $30: 1$ & $60: 1$ & $120: 1$ \\
\cline { 2 - 5 } Compound and $\mathrm{C}$ content & & & & \\
decane $\mathrm{C}_{10}$ & $<1$ & $<1$ & $<1$ & $<1$ \\
undecane $\mathrm{C}_{11}$ & $<1$ & $<1$ & $<1$ & $<1$ \\
dodecane $\mathrm{C}_{12}$ & 5.1 & $<1$ & $<1$ & $<1$ \\
tridecane $\mathrm{C}_{13}$ & 10.1 & 2.6 & 2.2 & 1.9 \\
tetradecane $\mathrm{C}_{14}$ & 13.4 & 2.5 & 1.9 & 1.9 \\
pentadecane $\mathrm{C}_{15}$ & 21.9 & 6.7 & 3.3 & 2.2 \\
hexadecane $\mathrm{C}_{16}$ & 33.5 & 13.3 & 5.4 & 5.4 \\
heptadecane $\mathrm{C}_{17}$ & 43.7 & 22.5 & 8.4 & 8.3 \\
octadecane $\mathrm{C}_{18}$ & 49.0 & 26.3 & 10.0 & 9.9 \\
nonadecane $\mathrm{C}_{19}$ & 55.1 & 28.3 & 10.8 & 10.9 \\
eicosane $\mathrm{C}_{20}$ & 74.8 & 36.8 & 14.2 & 15.8 \\
heneicosane $\mathrm{C}_{21}$ & 54.2 & 25.7 & 9.0 & 9.4 \\
docosane $\mathrm{C}_{22}$ & 59.9 & 28.2 & 10.8 & 10.9 \\
tricosane $\mathrm{C}_{23}$ & 54.6 & 27.2 & 12.5 & 12.6 \\
tetracosane $\mathrm{C}_{24}$ & 56.2 & 30.2 & 14.6 & 13.1 \\
pentacosane $\mathrm{C}_{25}$ & 56.7 & 29.3 & 14.2 & 17.2 \\
hexacosane $\mathrm{C}_{26}$ & 63.2 & 36.7 & 15.7 & 20.2 \\
octacosane $\mathrm{C}_{28}$ & 75.2 & 49.0 & 12.4 & 14.4 \\
pristane $\mathrm{C}_{17}$ & 78.5 & 51.9 & 30.1 & 29.8 \\
phytane $\mathrm{C}_{20}$ & 63.3 & 42.7 & 30.2 & 30.5 \\
& & & & \\
\hline & & & &
\end{tabular}


Table 7. Remaining percent of individual hydrocarbon compounds after 90 days in the growth chamber.

\begin{tabular}{|c|c|c|c|c|}
\hline \multirow{3}{*}{$\begin{array}{l}\text { Nitrogemn Treatment }(\mathrm{C}: \mathrm{N}) \\
\text { Compound and } \mathrm{C} \text { content }\end{array}$} & \multicolumn{4}{|c|}{ Day 90} \\
\hline & no N & $30: 1$ & $60: 1$ & $120: 1$ \\
\hline & & & & \\
\hline decane $C_{10}$ & $<1$ & $<1$ & $<1$ & $<1$ \\
\hline undecane $C_{11}$ & $<1$ & $<1$ & $<1$ & $<1$ \\
\hline dodecane $C_{12}$ & $<1$ & $<1$ & $<1$ & $<1$ \\
\hline tridecane $\mathrm{C}_{13}$ & 3.5 & 1.1 & $<1$ & $<1$ \\
\hline tetradecane $C_{14}$ & 10.5 & 2.9 & 1.8 & 1.8 \\
\hline pentadecane $C_{15}$ & 28.4 & 14.3 & 13.2 & 11.5 \\
\hline hexadecane $\mathrm{C}_{16}$ & 18.6 & 4.8 & 4.2 & 3.6 \\
\hline heptadecane $C_{17}$ & 22.2 & 6.4 & 5.4 & 5.7 \\
\hline octadecane $\mathrm{C}_{18}$ & 35.7 & 14.5 & 13.9 & 12.6 \\
\hline nonadecane $\mathrm{C}_{19}$ & 26.3 & 7.2 & 6.0 & 6.1 \\
\hline eicosane $C_{20}$ & 26.7 & 7.6 & 6.8 & 6.6 \\
\hline heneicosane $C_{21}$ & 31.7 & 9.4 & 8.5 & 8.2 \\
\hline docosane $C_{22}$ & 27.4 & 6.4 & 6.0 & 5.3 \\
\hline tricosane $C_{23}$ & 24.3 & 4.5 & 4.7 & 4.1 \\
\hline tetracosane $C_{24}$ & 20.9 & 4.2 & 4.2 & 4.1 \\
\hline pentacosane $C_{2 s}$ & 56.7 & 29.3 & 14.2 & 17.2 \\
\hline hexacosane $\mathrm{C}_{26}$ & 63.2 & 36.7 & 15.7 & 20.2 \\
\hline octacosane $C_{28}$ & 75.2 & 49.0 & 12.4 & 14.4 \\
\hline pristane $\mathrm{C}_{17}$ & 78.5 & 51.9 & 30.1 & 29.8 \\
\hline phytane $\mathrm{C}_{20}$ & 63.3 & 42.7 & 30.2 & 30.5 \\
\hline
\end{tabular}


Table 4. Calculated half life ( $\mathrm{t}_{1 / 2}$, days) of individual components of crude oil as affected by inoculation.

\begin{tabular}{lcccccccc}
\hline Treatment & Tetradecane & Hexadecane & Heptadecane & Pristane & Octadecane & Nonadecane & Docosane & Phytane \\
\cline { 2 - 8 } Sterile soil & 99.0 & 96.0 & 96.0 & 96.4 & 96.4 & 96.4 & 96.4 & 96.4 \\
Soil & 6.4 & 6.3 & 5.5 & 18.7 & 21.7 & 4.2 & 3.7 & 19.8 \\
Syborn & 2.2 & 2.5 & 1.8 & 34.7 & 2.1 & 2.4 & 1.8 & 46.2 \\
Interbio SSC & 2.8 & 3.5 & 2.3 & 40.7 & 2.3 & 3.3 & 22.0 & 34.7 \\
Hydrobac & 3.8 & 3.9 & 3.7 & 33.0 & 3.5 & 3.7 & 3.3 & 25.7 \\
DBC Plus R5 & 4.9 & 6.0 & 5.5 & 19.3 & 4.8 & 4.7 & 4.5 & 23.1 \\
M5 & 17.8 & 23.9 & 21.7 & 6930 & 21.7 & 23.9 & 23.9 & 231 \\
M-B4W & 14.4 & 22.4 & 21.0 & 347 & 23.9 & 24.8 & 25.7 & 693 \\
\hline
\end{tabular}




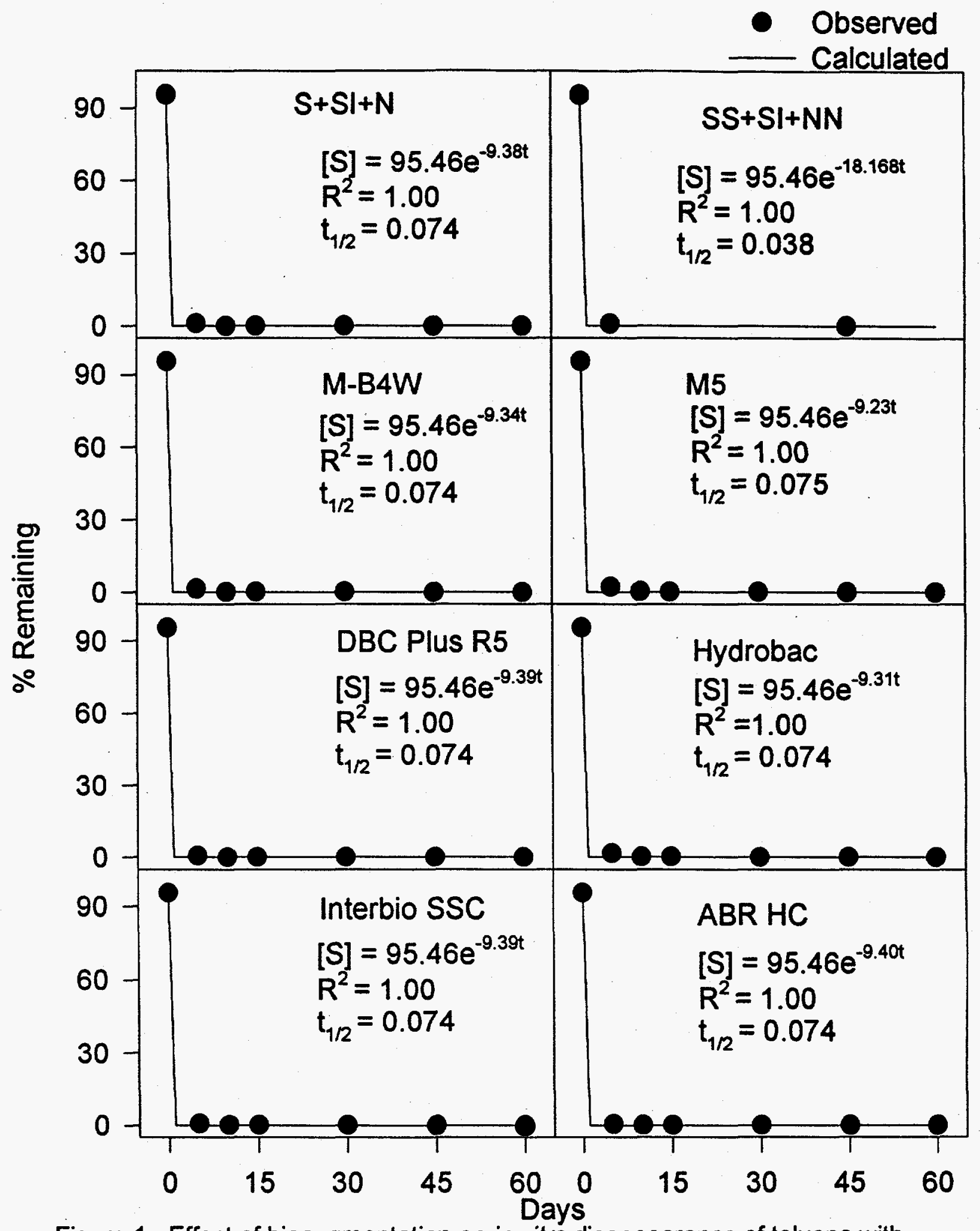

Figure 1. Effect of bioaugmentation on in vitro disappearance of toluene with time in surface $(0-7.5 \mathrm{~cm})$ soil.

Rates in the presence of an inoculum should be compared with those of the indigenous soil $(\mathrm{S}+\mathrm{SI})$ and of a sterile soil $(\mathrm{SS}+\mathrm{SI})$. Soils were amended with $\mathrm{N}$ and $\mathrm{P}$. 


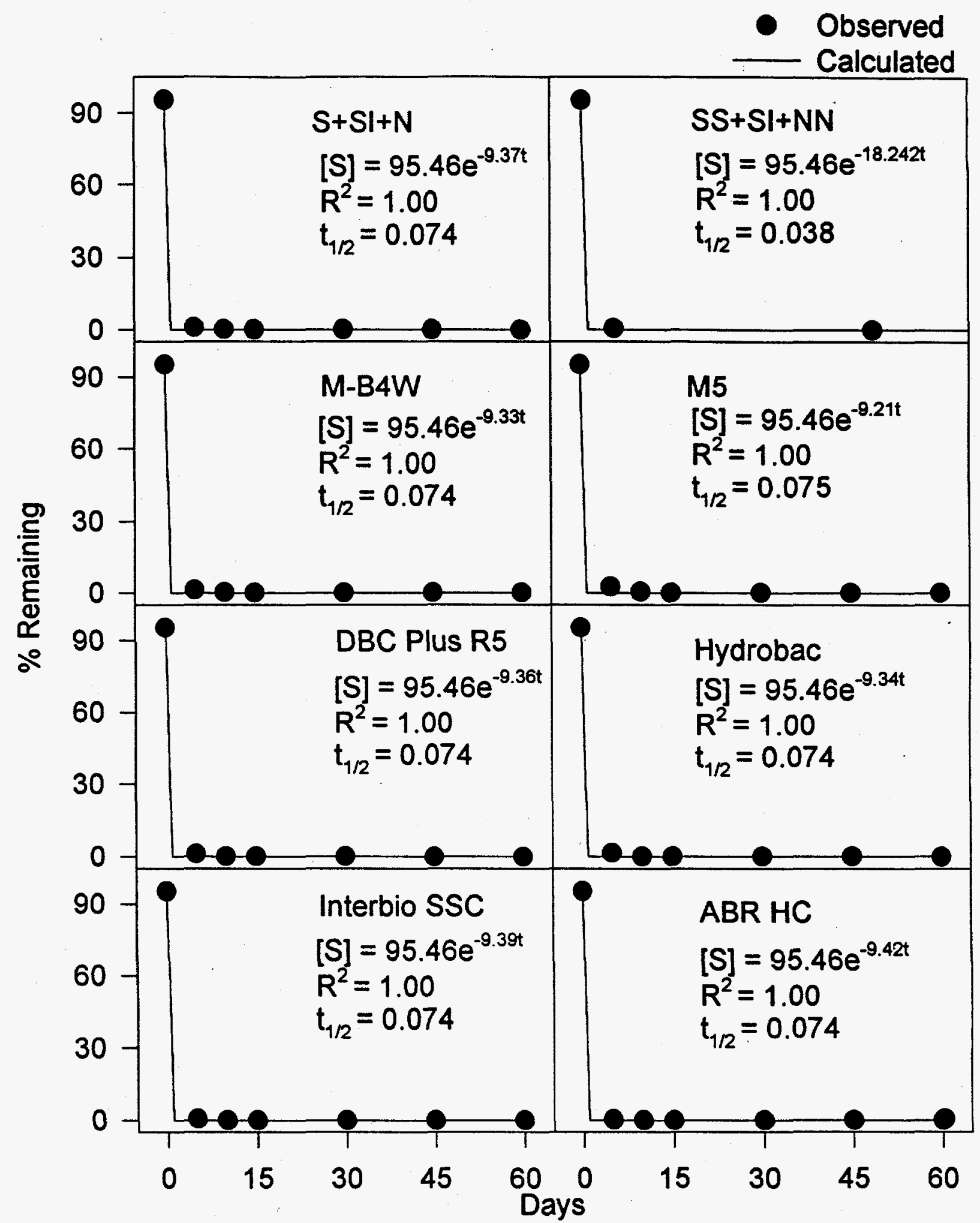

Figure 2. Effect of bioaugmentation on in vitro disappearance of toluene with time in subsurface $(>45 \mathrm{~cm})$ soil.

Rates in the presence of an inoculum should be compared with those of the indigenous soil $(\mathrm{S}+\mathrm{SI})$ and of a sterile soil $(\mathrm{SS}+\mathrm{SI})$. Soils were amended with $\mathrm{N}$ and $\mathrm{P}$. 


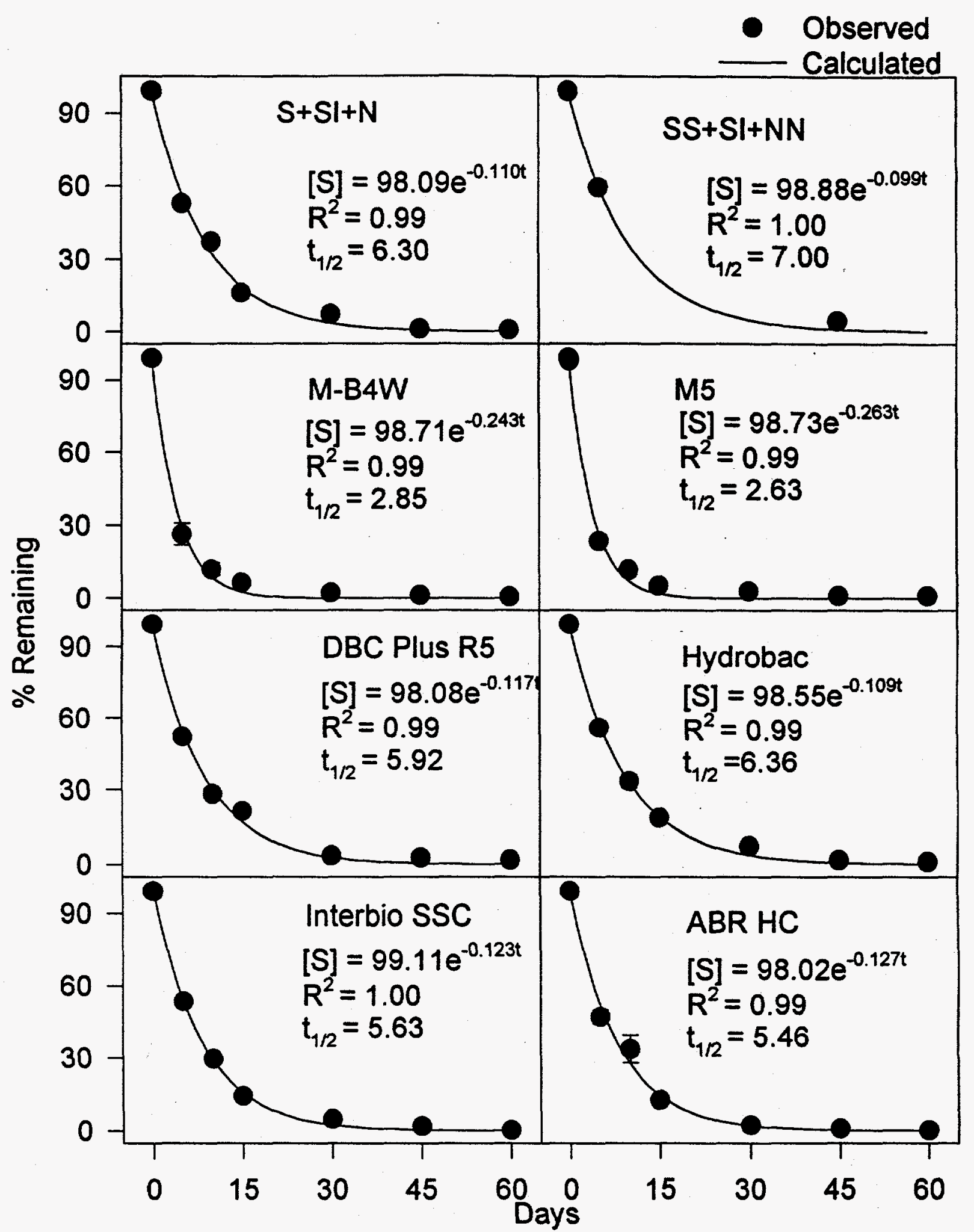

Figure 3. Effect of bioaugmentation on in vitro disappearance of 0-dichlorobenzene with time in surface $(0-7.5 \mathrm{~cm})$ soil.

Rates in the presence of an inoculum should be compared with those of the indigenous soil $(S+S I)$ and of a sterile soil $(S S+S I)$. Soils were amended with $\mathrm{N}$ and $\mathrm{P}$. 


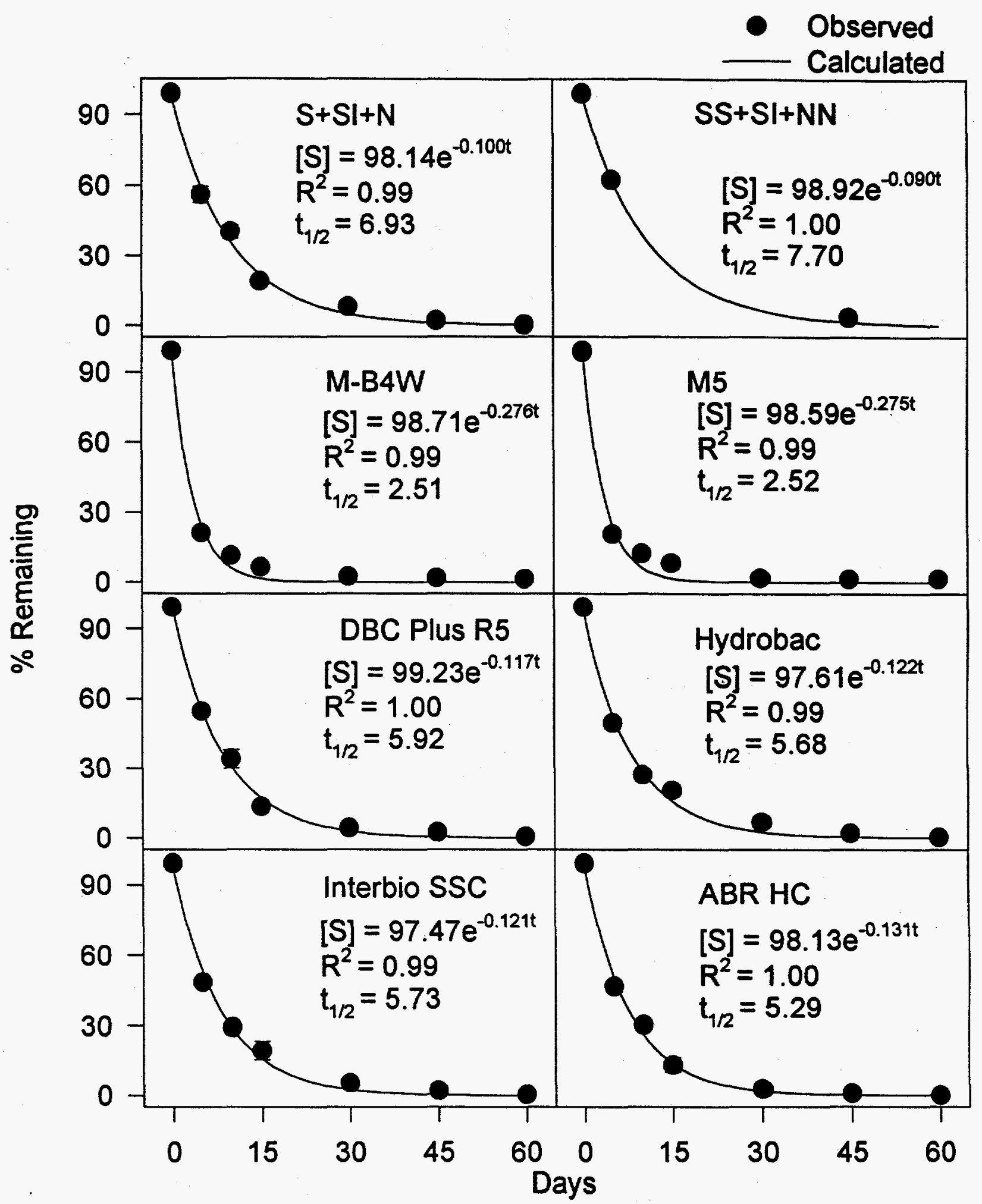

Figure 4. Effect of bioaugmentation on in vitro disappearance of o-dichlorobenzene with time in subsurface $(>45 \mathrm{~cm})$ soil.

Rates in the presence of an inoculum should be compared with those of the indigenous soil $(\mathrm{S}+\mathrm{SI})$ and of a sterile soil $(\mathrm{SS}+\mathrm{SI})$. Soils were amended with $\mathrm{N}$ and $\mathrm{P}$. 


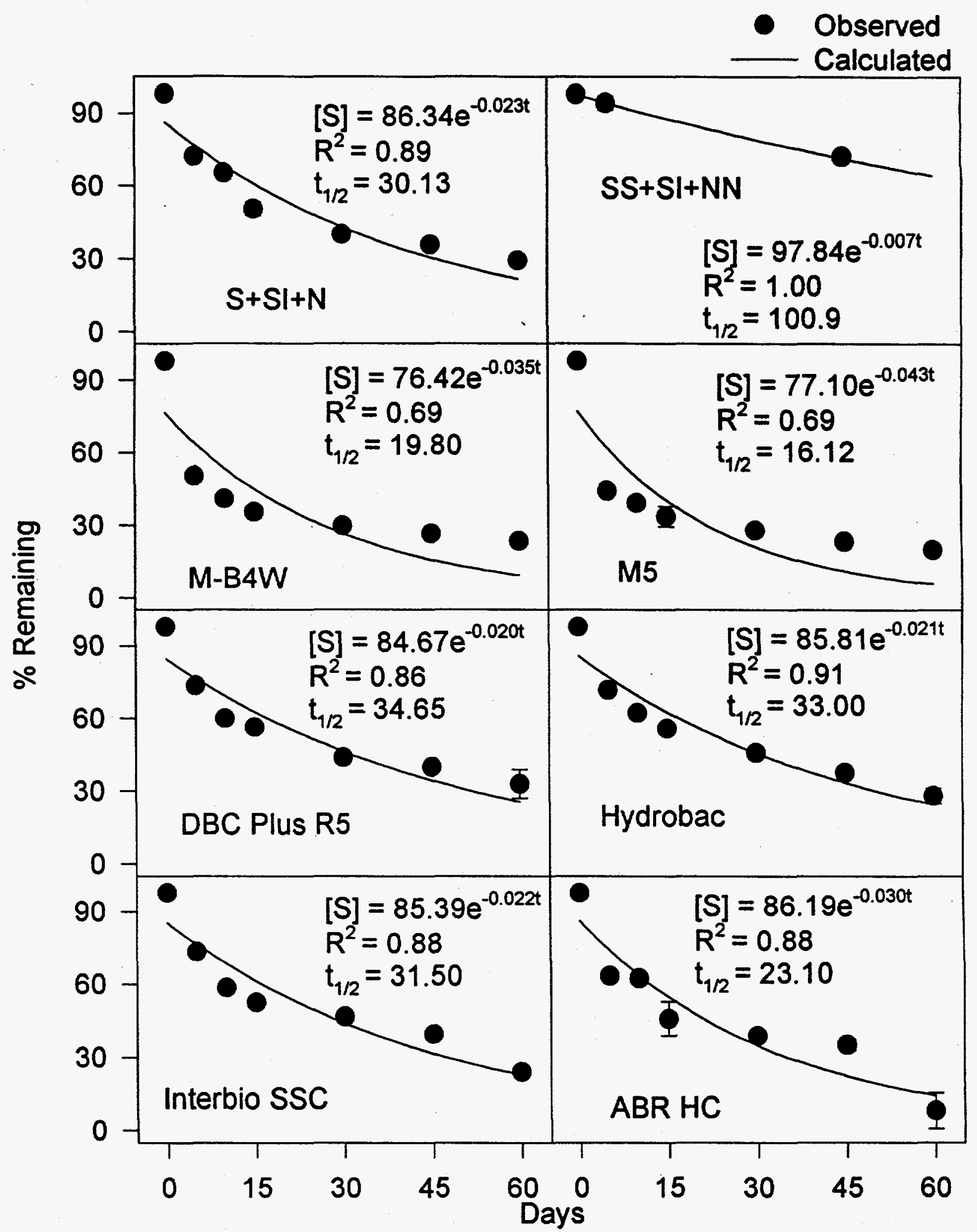

Figure 5. Effect of bioaugmentation on in vitro disappearance of naphthalene with time in surface $(0-7.5 \mathrm{~cm})$ soil.

Rates in the presence of an inoculum should be compared with those of the indigenous soil $(\mathrm{S}+\mathrm{SI})$ and of a sterile soil $(\mathrm{SS}+\mathrm{SI})$. Soils were amended with $\mathrm{N}$ and $\mathrm{P}$. 


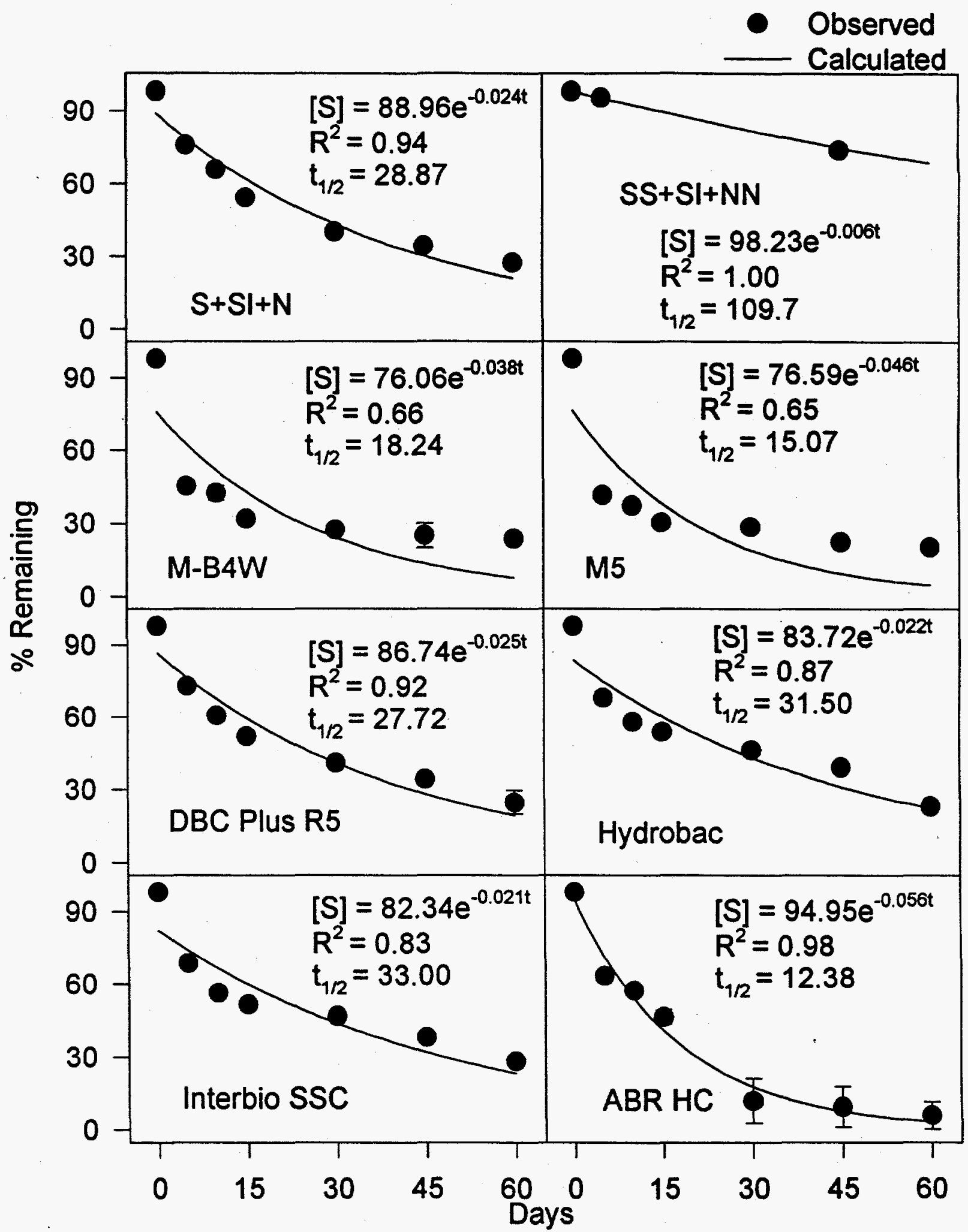

Figure 6. Effect of bioaugmentation on in vitro disappearance of naphathalene with time in subsurface $(>45 \mathrm{~cm})$ soil.

Rates in the presence of an inoculum should be compared with those of the indigenous soil $(S+S I)$ and of a sterile soil $(S S+S I)$. Soils were amended with $\mathrm{N}$ and $\mathrm{P}$. 


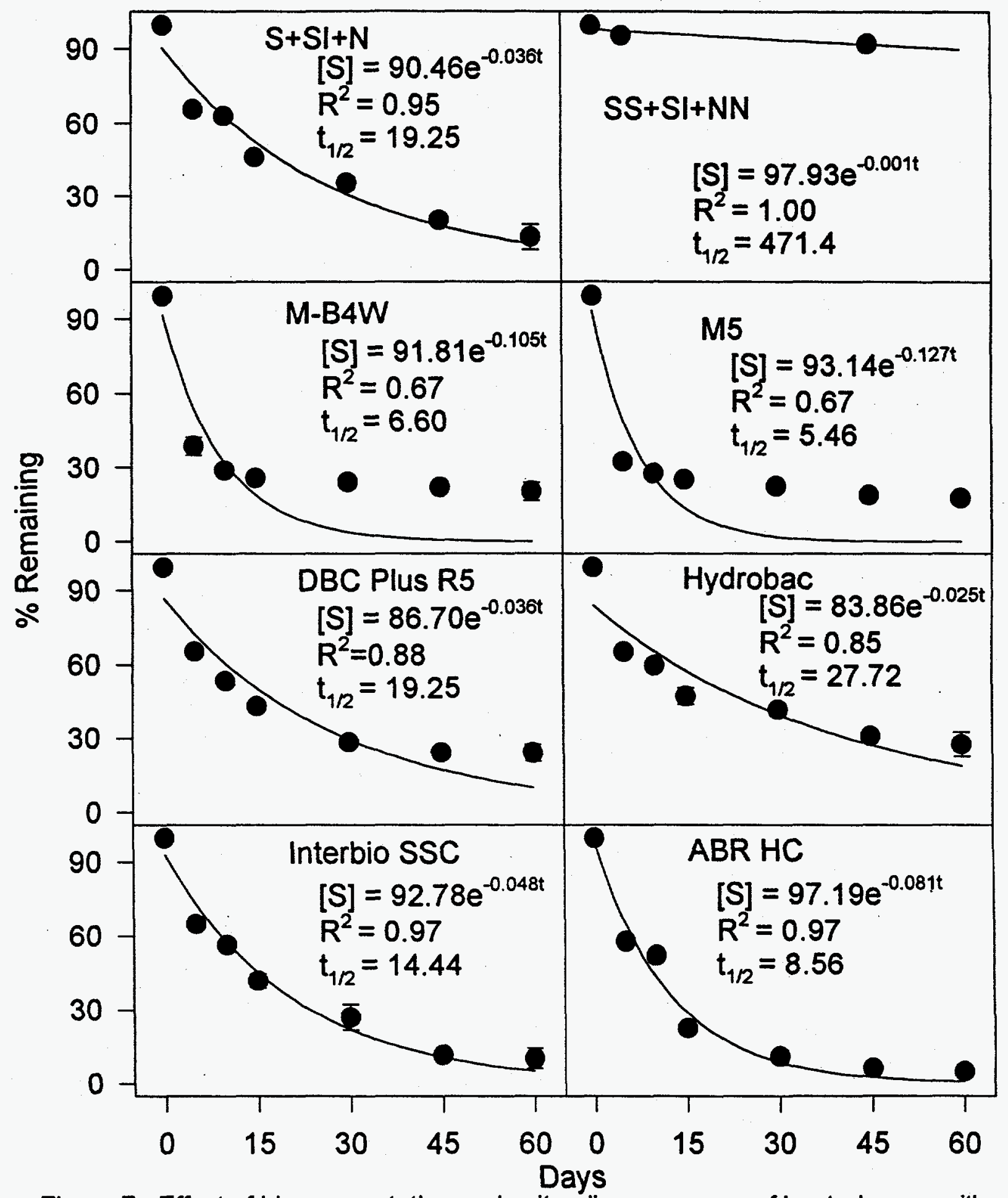

Figure 7. Effect of bioaugmentation on in vitro disappearance of heptadecane with time in surface $(0-7.5 \mathrm{~cm})$ soil.

Rates in the presence of an inoculum should be compared with those of the indigenous soil $(\mathrm{S}+\mathrm{SI})$ and of a sterile soil $(\mathrm{SS}+\mathrm{SI})$. Soils were amended with $\mathrm{N}$ and $\mathrm{P}$. 


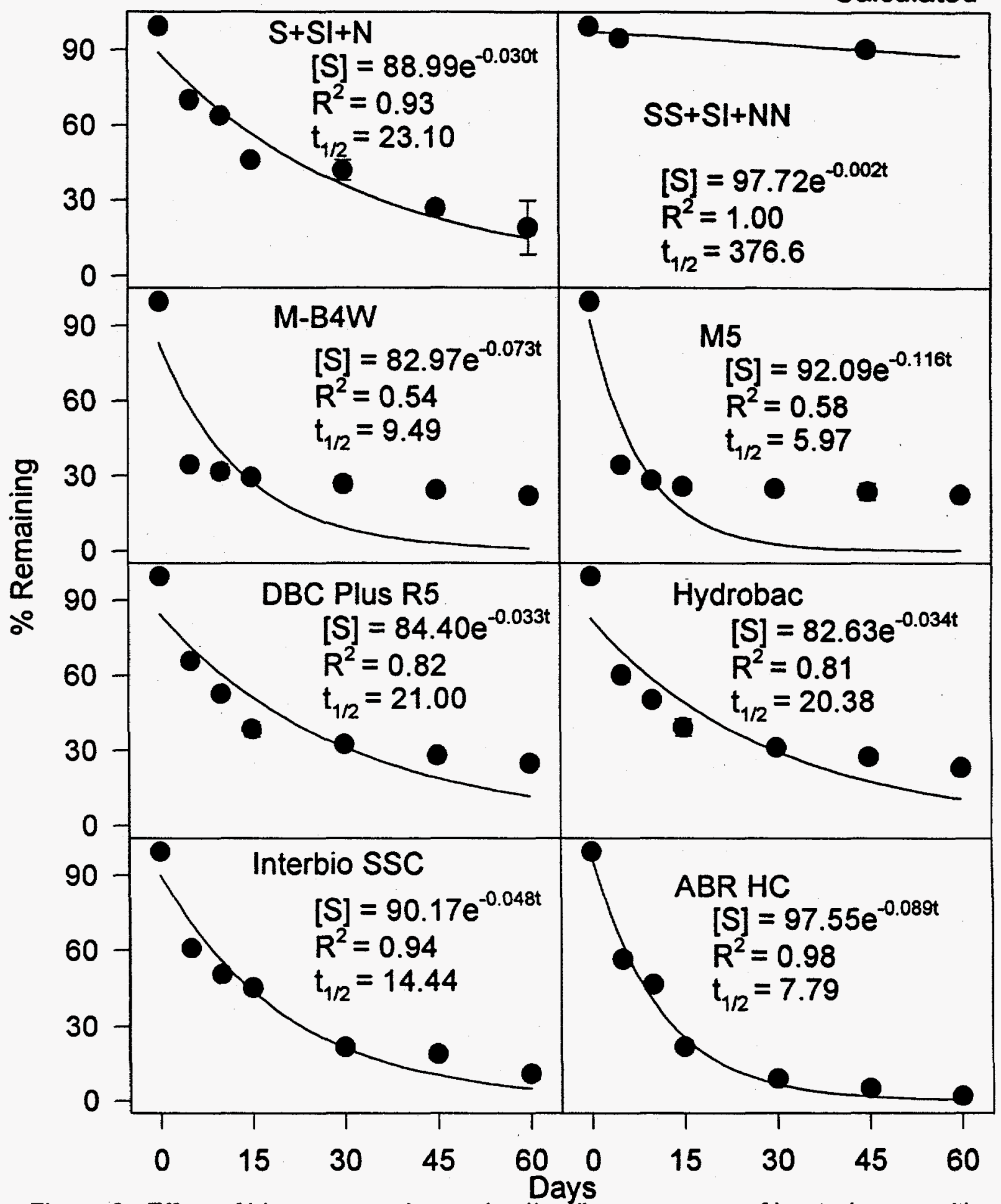

Figure 8. Effect of bioaugmentation on in vitro disappearance of heptadecane with time in subsurface $(>45 \mathrm{~cm})$ soil.

Rates in the presence of an inoculum should be compared with those of the indigenous soil $(\mathrm{S}+\mathrm{SI})$ and of a sterile soil $(\mathrm{SS}+\mathrm{SI})$. Soils were amended with $\mathrm{N}$ and $\mathrm{P}$. 


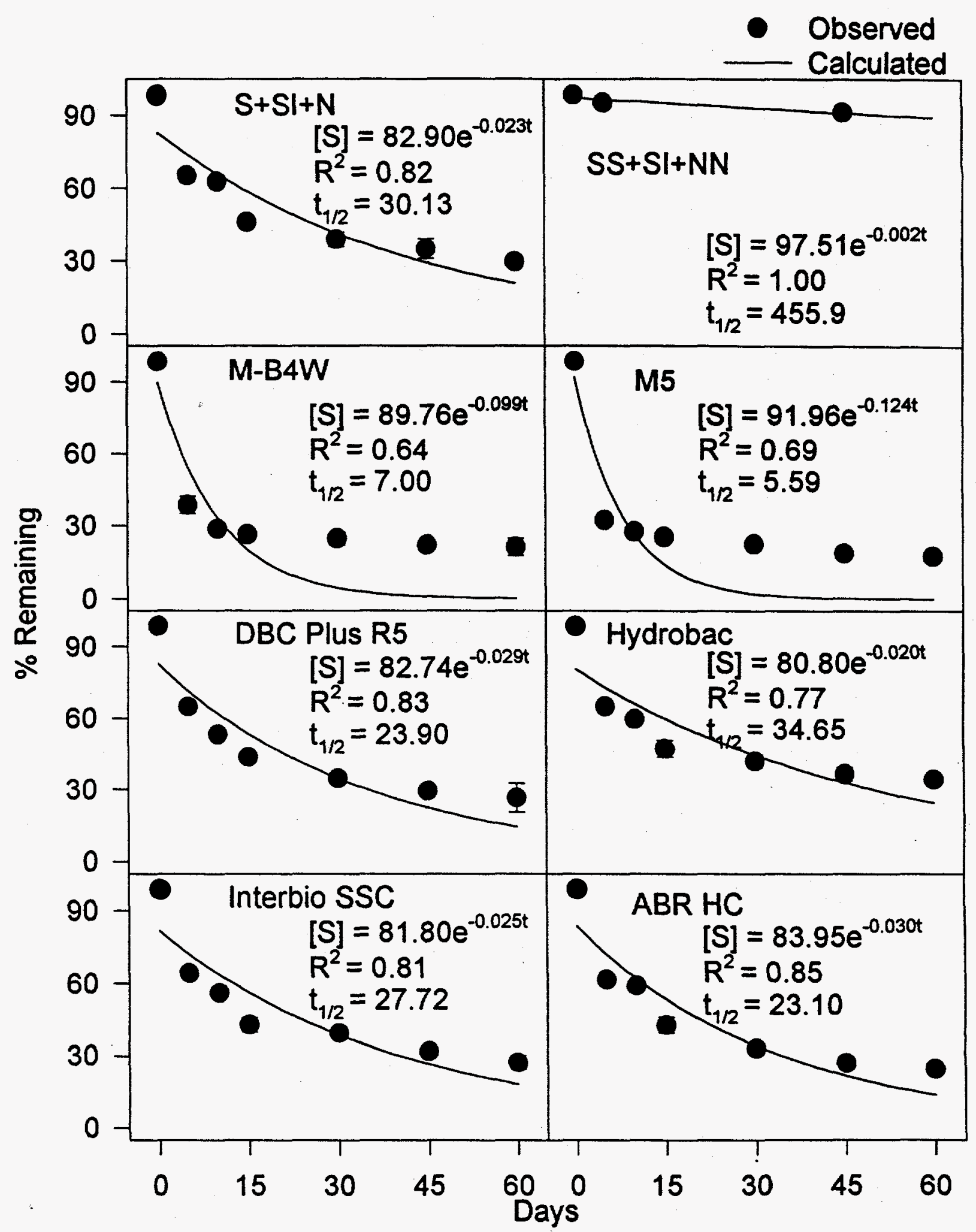

Figure 9. Effect of bioaugmentation on in vitro disappearance of pristane with time in surface $(0-7.5 \mathrm{~cm})$ soil.

Rates in the presence of an inoculum should be compared with those of the indigenous soil $(\mathrm{S}+\mathrm{SI})$ and of a sterile soil $(\mathrm{SS}+\mathrm{SI})$. Soils were amended with $N$ and $P$. 


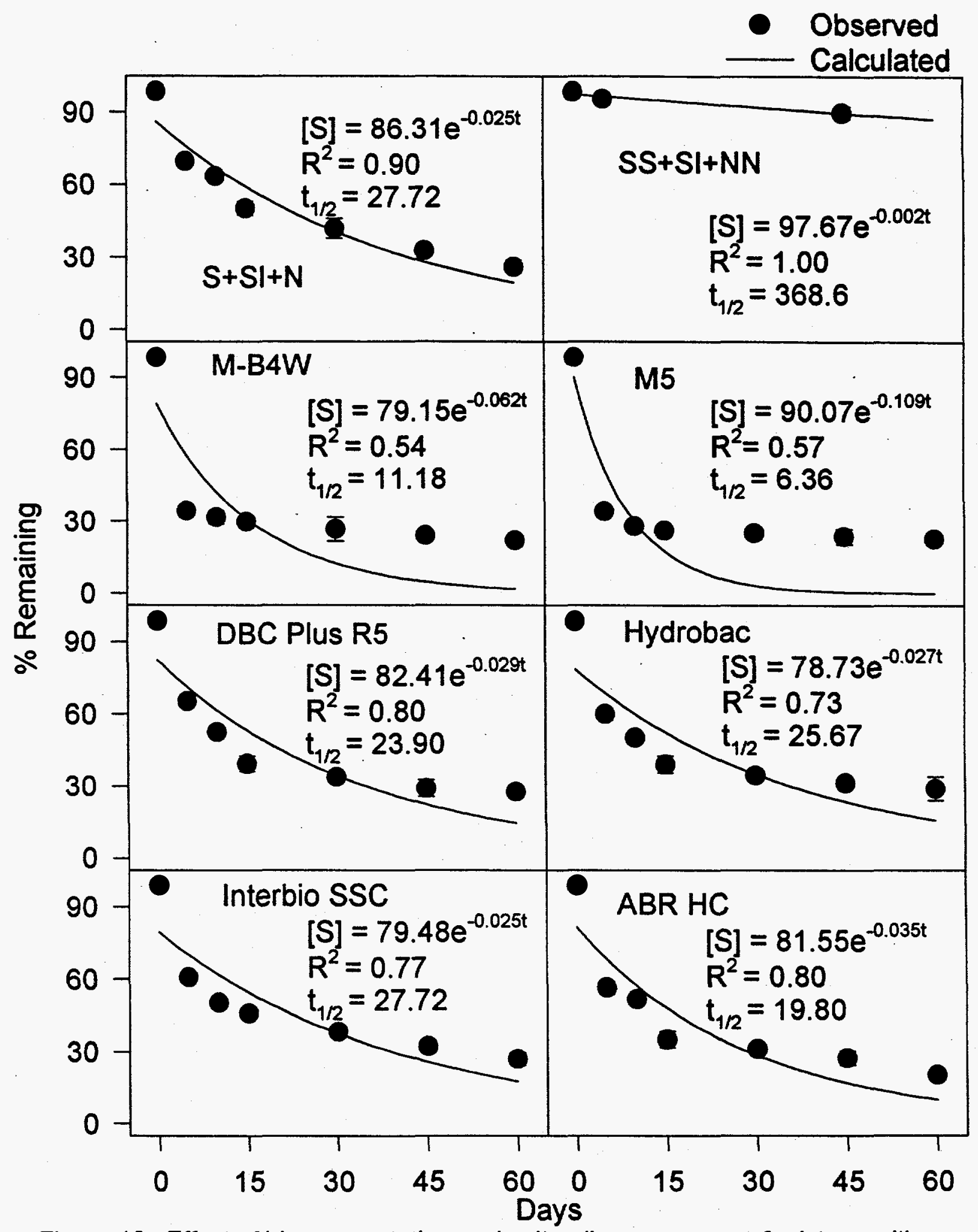

Figure 10. Effect of bioaugmentation on in vitro disappearance of pristane with time in subsurface $(>45 \mathrm{~cm}$ ) soil.

Rates in the presence of an inoculum should be compared with those of the indigenous soil $(\mathrm{S}+\mathrm{SI})$ and of a sterile soil (SS+SI). Soils were amended with $\mathbf{N}$ and $\mathbf{P}$. 


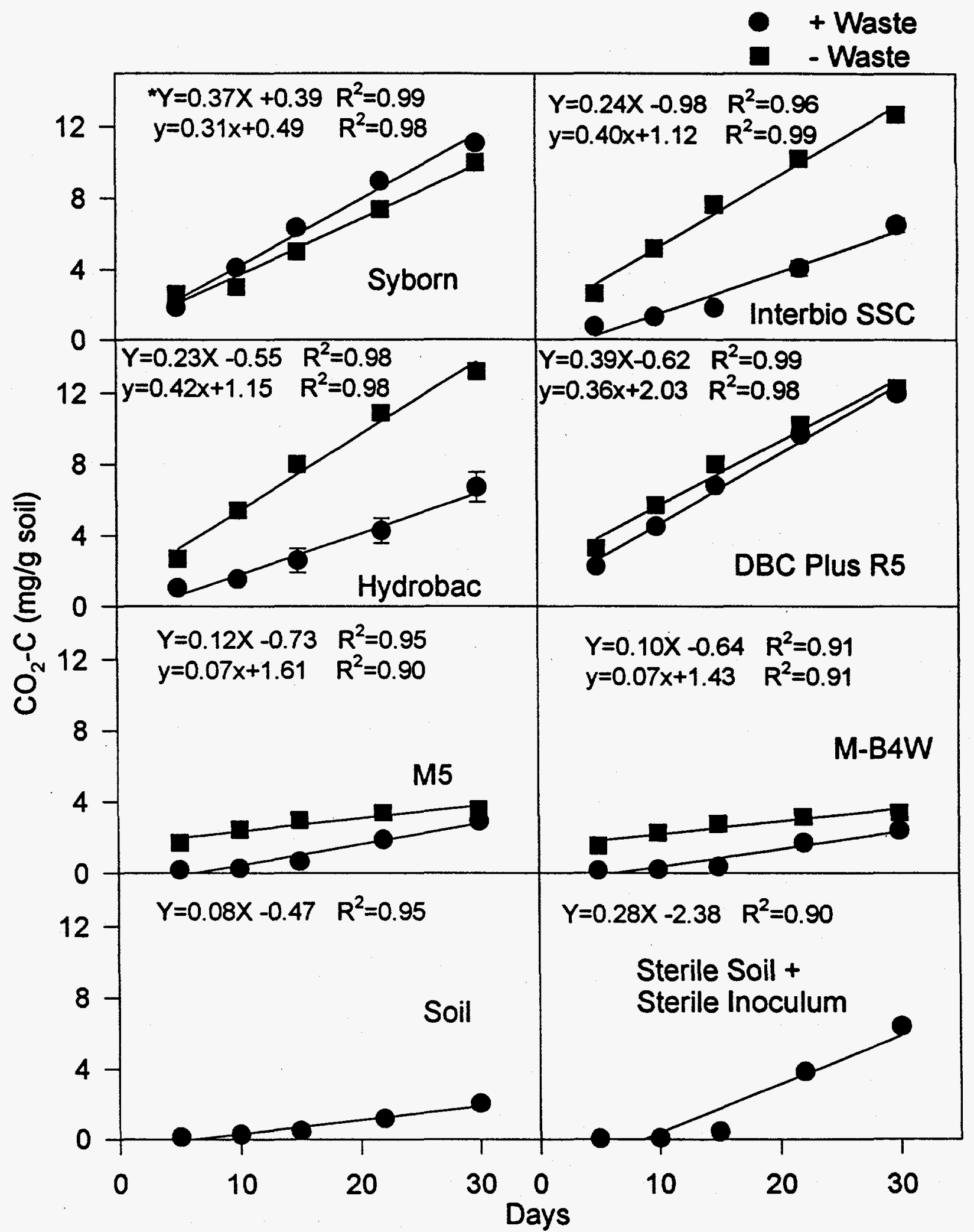

Figure 11. Effect of waste oil application on cumulative $\mathrm{CO}_{2}$ production from native and bioaugmanted surface $(0-7.5 \mathrm{~cm})$ soil.

Regression analyses : Upper case equation describes waste treated soil and lower case equation describes soil receiving no organic waste. 


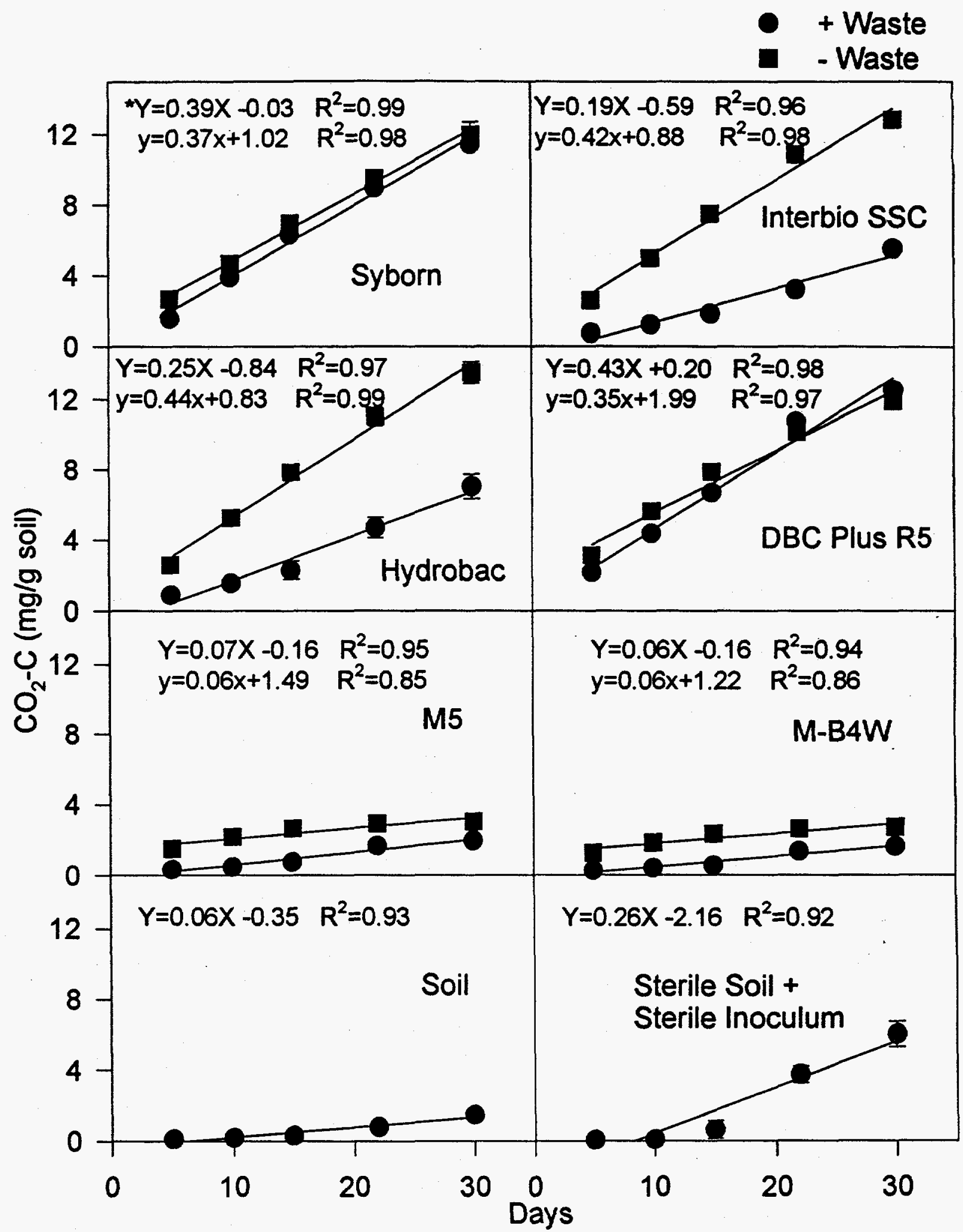

Figure 12. Effect of waste oil application on cumulative $\mathrm{CO}_{2}$ production from native and bioaugmanted subsurface $(>45 \mathrm{~cm})$ soil.

Regression analyses : Upper case equation describes waste treated soil and lower case equation describes soil receiving no organic waste. 


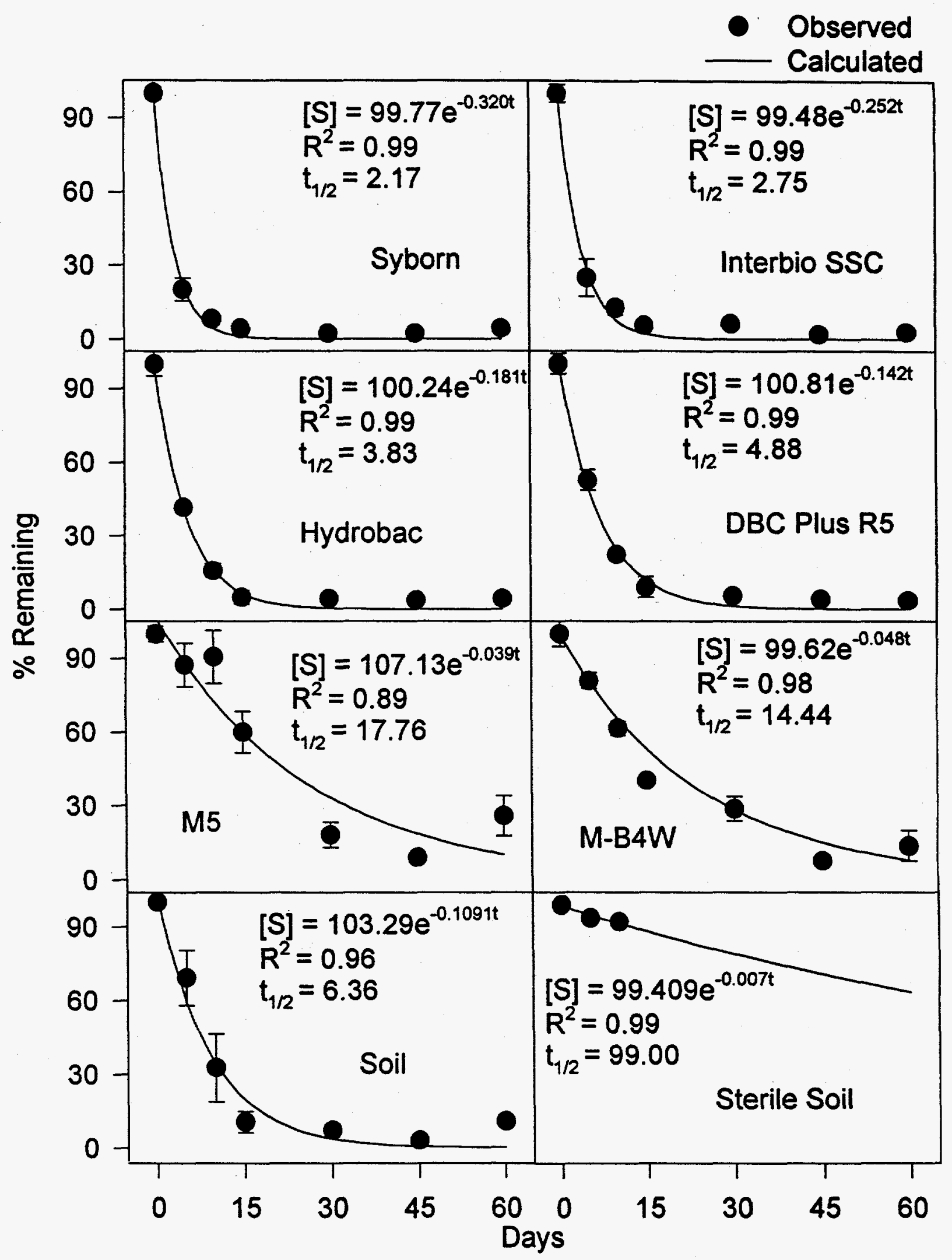

Figure 13. Effect of bioaugmentation on in vitro disappearance of tetradecane with time in crude oil contaminated surface $(0-7.5 \mathrm{~cm})$ soil. 
- Observed

Calculated

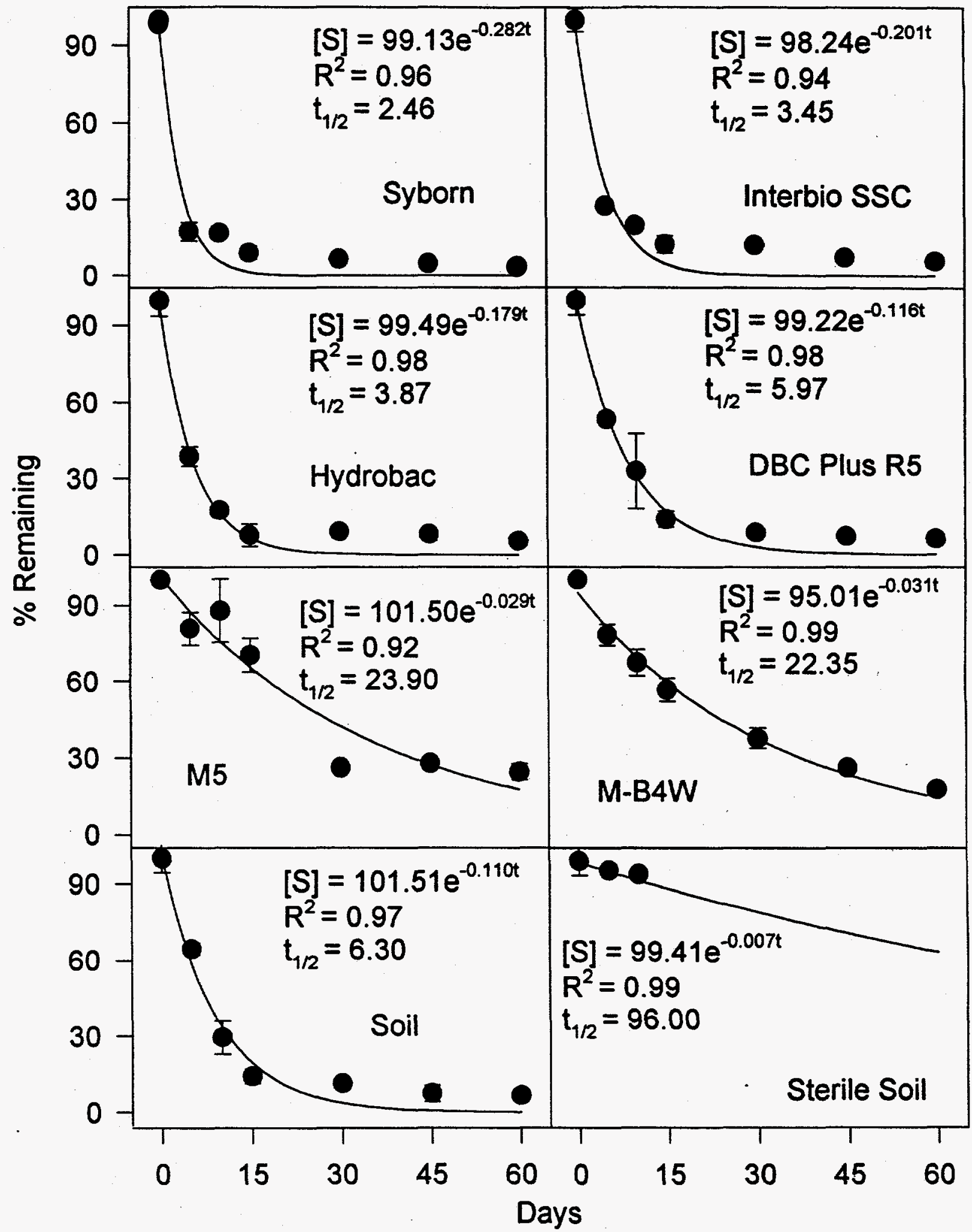

Figure 14. Effect of bioaugmentation on in vitro disappearance of hexadecane with time in crude oil contaminated surface $(0-7.5 \mathrm{~cm})$ soil. 
- Observed

Calculated

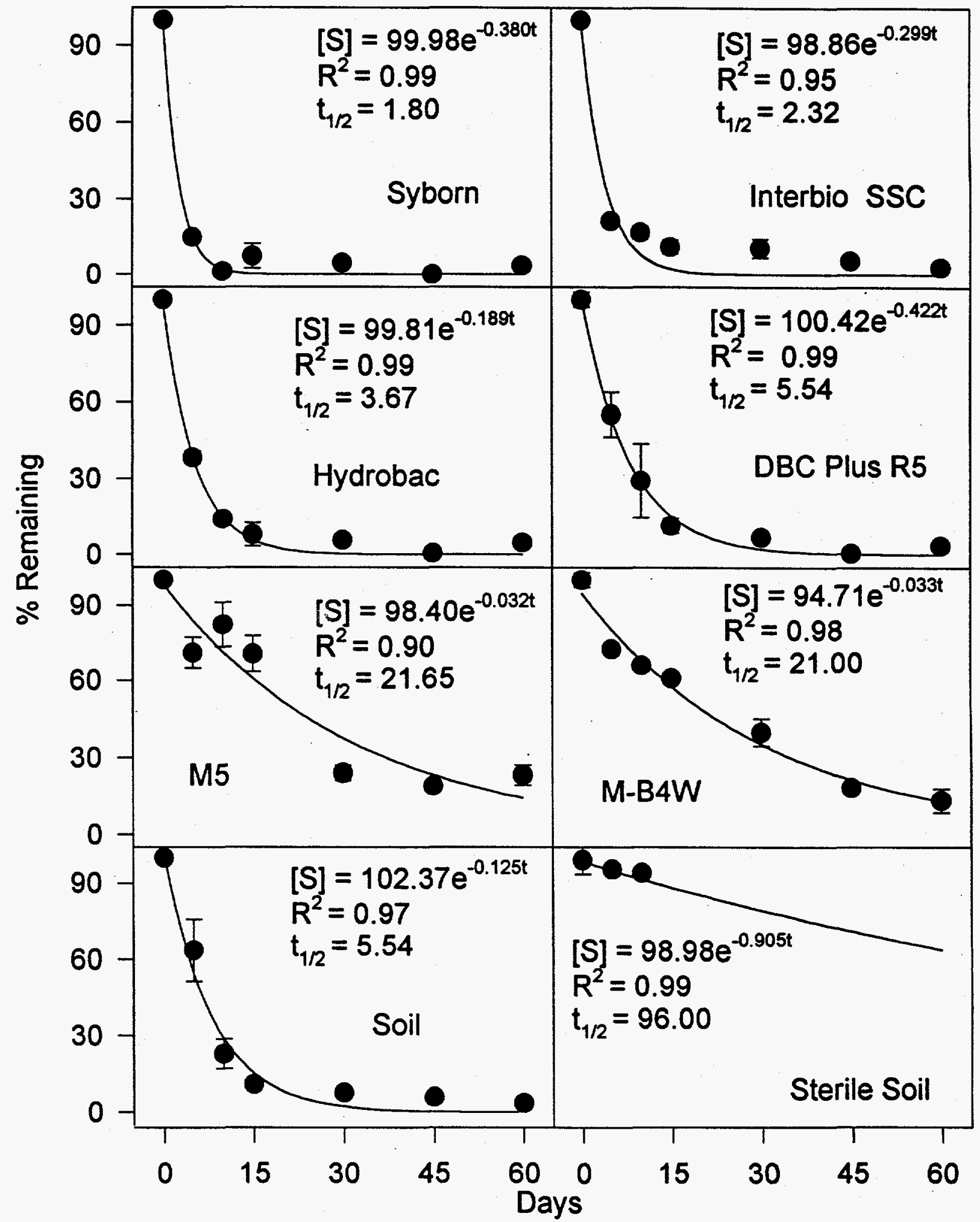

Figure 15. Effect of bioaugmentation on in vitro disappearance of heptadecane with time in crude oil contaminated surface $(0-7.5 \mathrm{~cm})$ soil. 


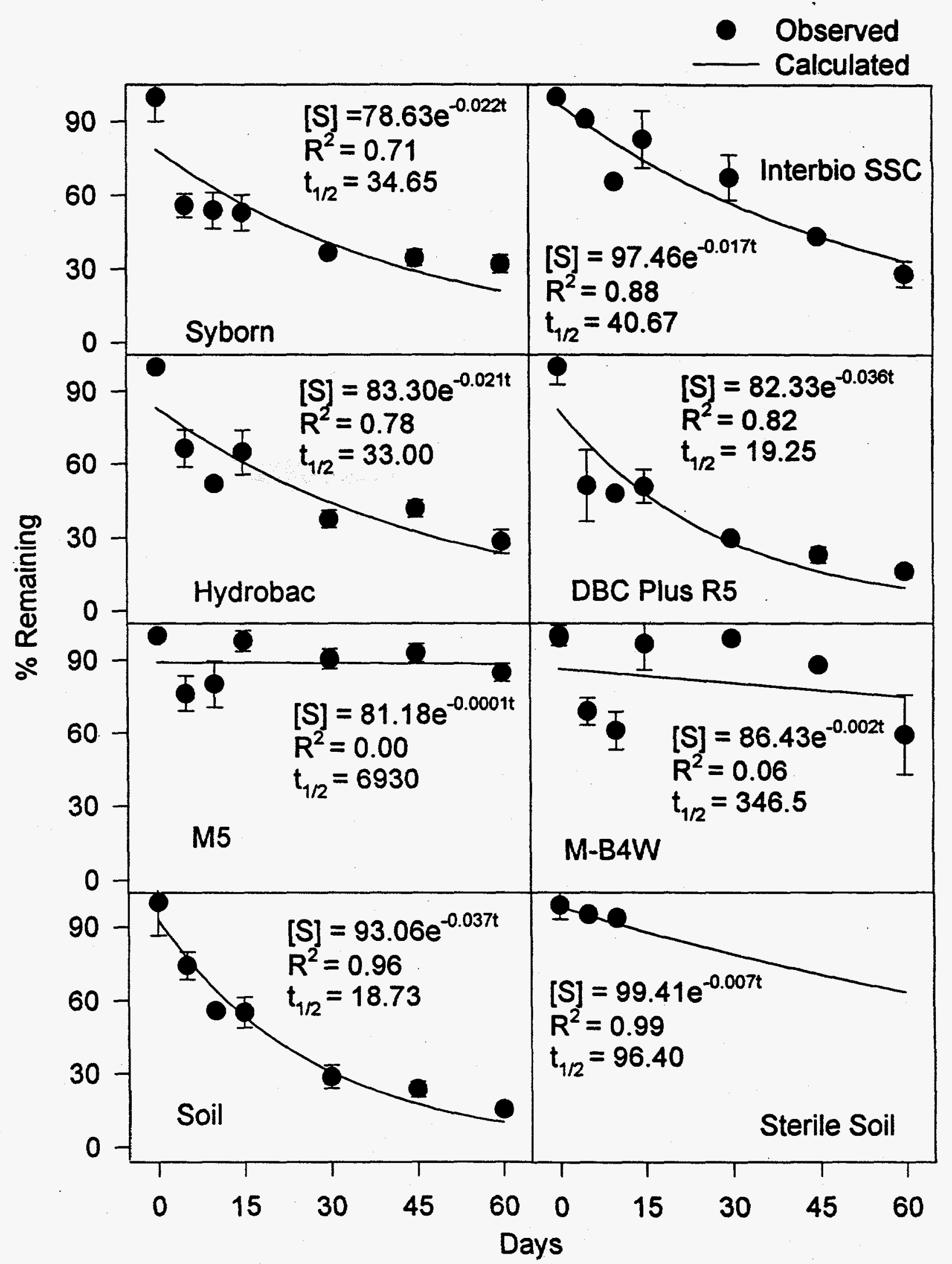

Figure 16. Effect of bioaugmentation on in vitro disappearance of pristane with time in crude oil contaminated surface $(0-7.5 \mathrm{~cm})$ soil. 


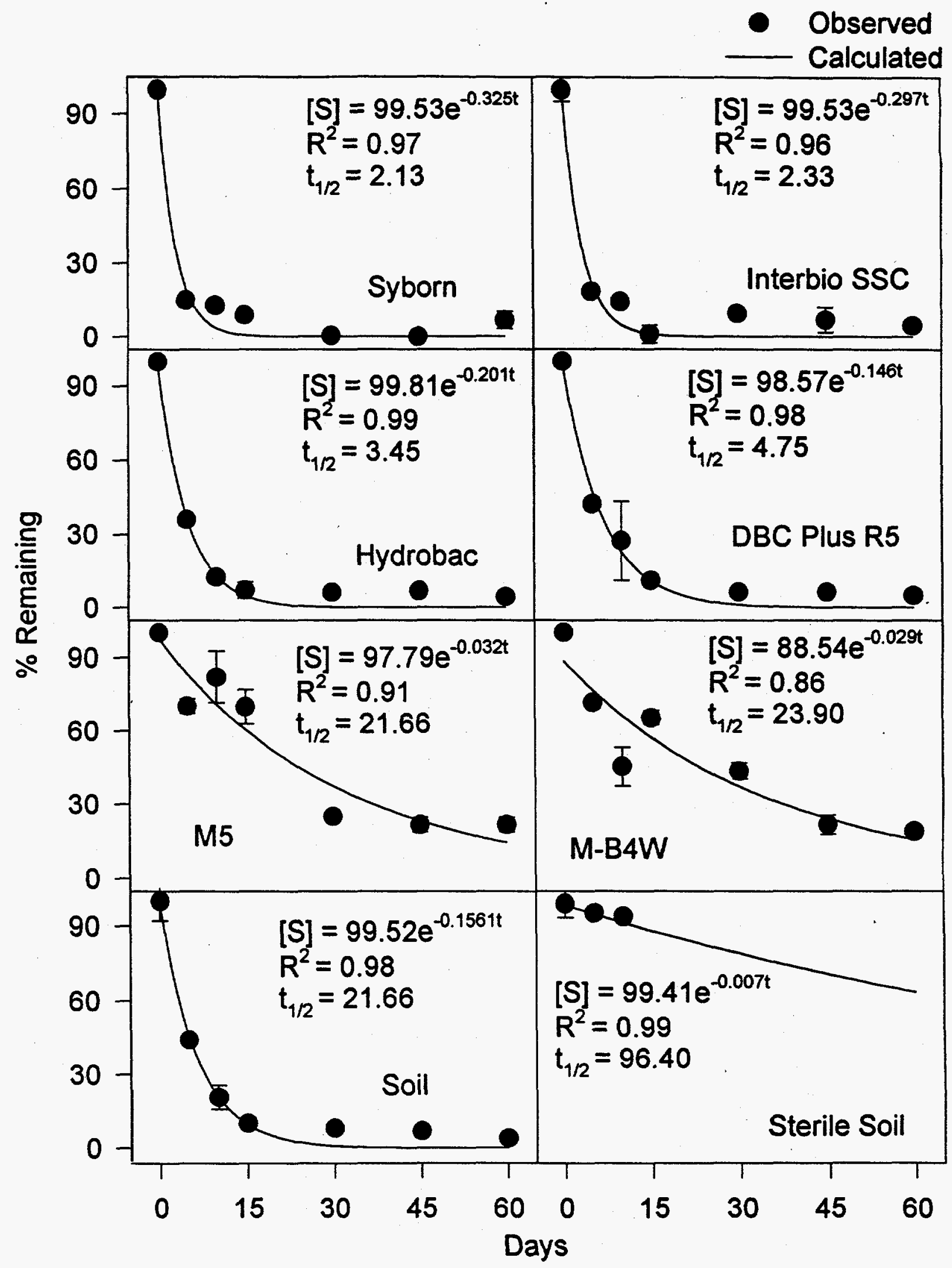

Figure 17. Effect of bioaugmentation on in vitro disappearance of octadecane with time in crude oil contaminated surface $(0-7.5 \mathrm{~cm})$ soil. 


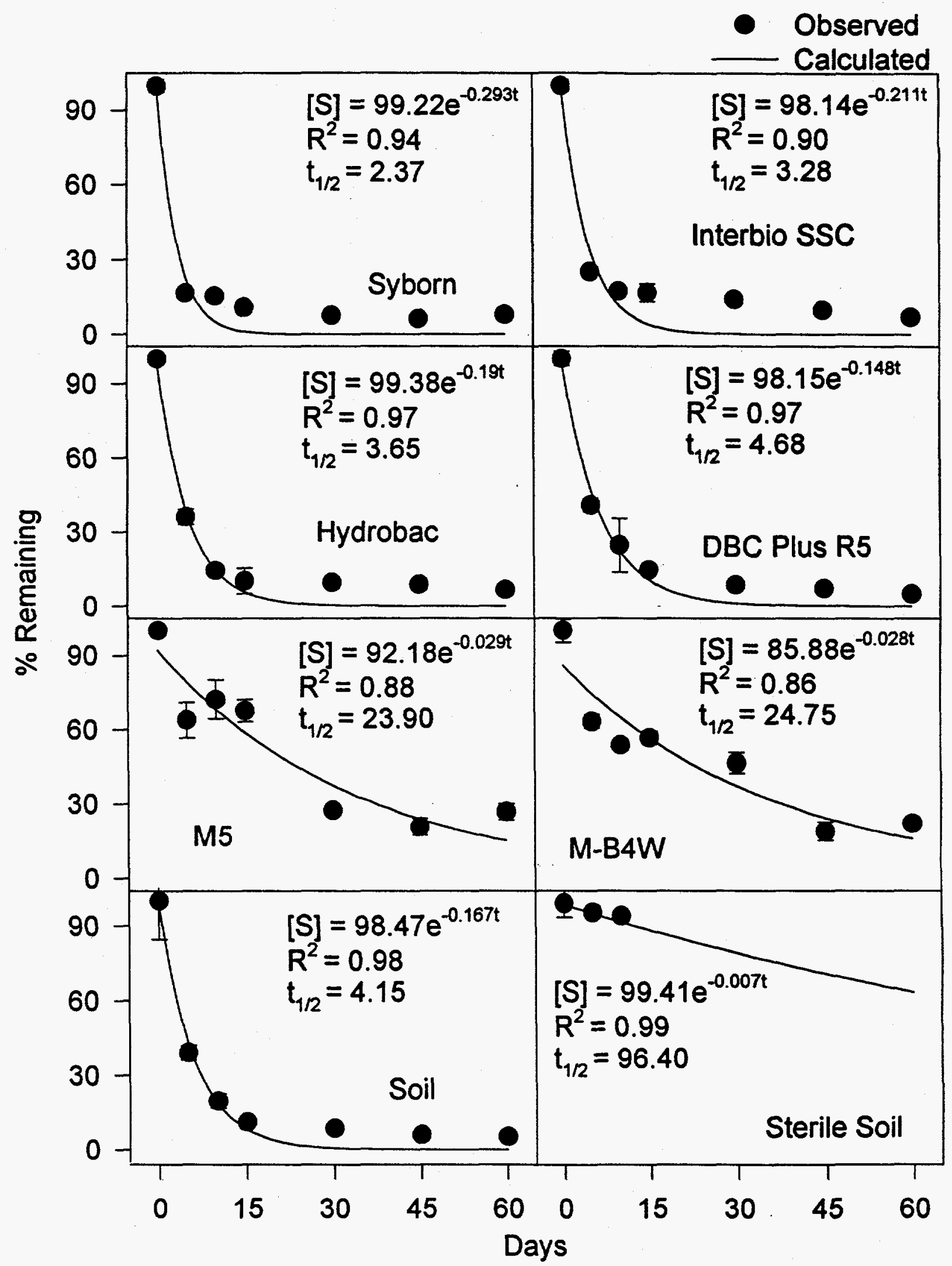

Figure 18. Effect of bioaugmentation on in vitro disappearance of nonadecane with time in crude oil contaminated surface $(0-7.5 \mathrm{~cm})$ soil. 


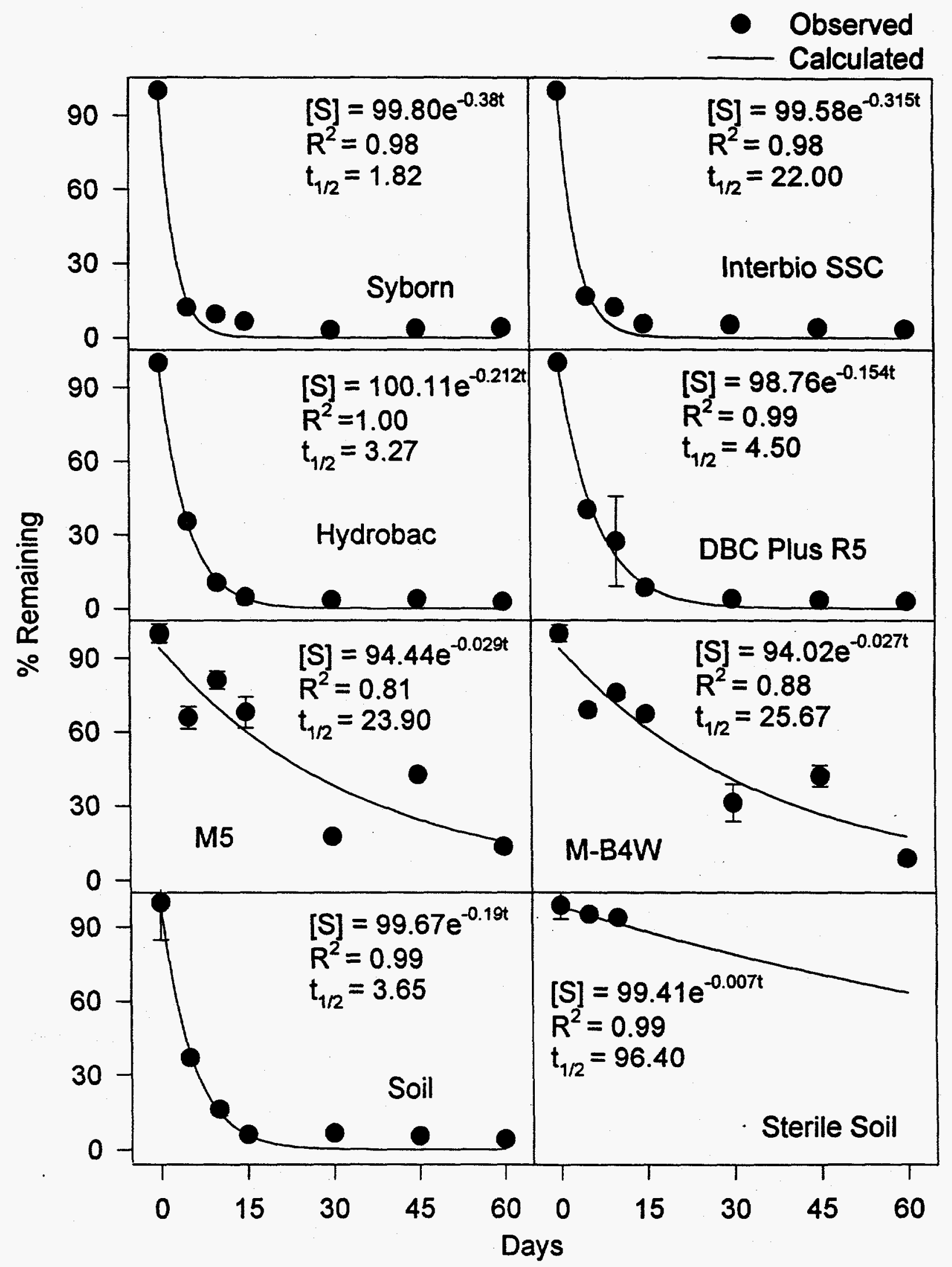

Figure 19. Effect of bioaugmentation on in vitro disappearance of docosane with time in crude oil contaminated surface $(0-7.5 \mathrm{~cm})$ soil. 


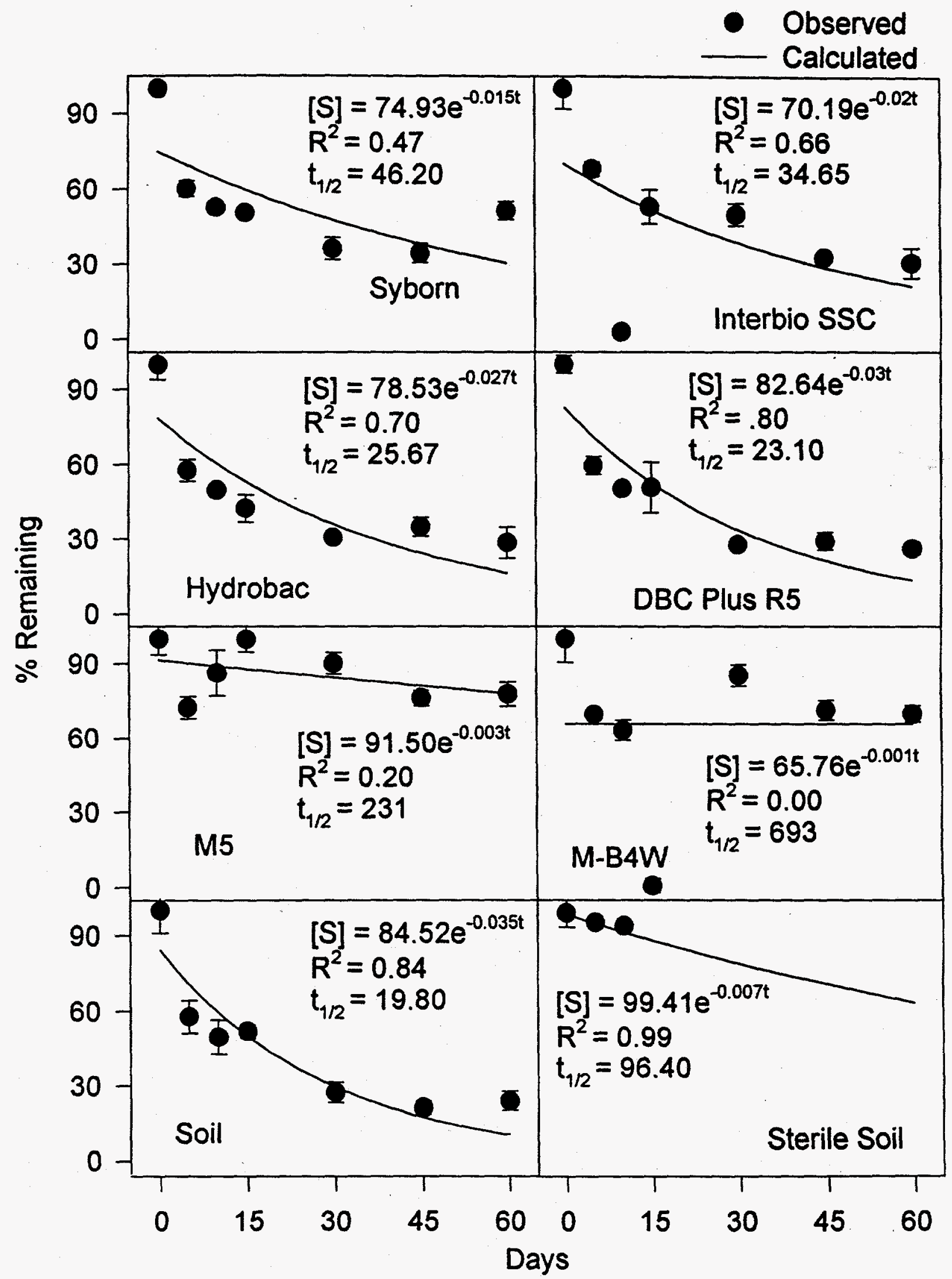

Figure 20. Effect of bioaugmentation on in vitro disappearance of phytane with time in crude oil contaminated surface $(0-7.5 \mathrm{~cm})$ soil. 
$-176-$ 
METC Task No. 1.4

Quarterly Technical Progress Report

Reporting Period: January 1, 1995 - March 31, 1995

Work Performed Under Contract

No: DE-FC21-92MC29467

\author{
For: \\ U.S. Department of Energy \\ Office of Fossil Energy \\ Morgantown Energy Technology Center \\ Morgantown, West Virginia
}

\author{
By: \\ H. Ilkin Bilgesu and Sam Ameri \\ Petroleum \& Natural Gas Engineering \\ West Virginia University \\ P.O. Box 6070 \\ Morgantown, WV 26506-6070
}

April 1995 
$-178-$ 


\begin{abstract}
$\underline{\text { ABSTRACT }}$
Contaminations of the subsurface soils are problems encountered in many areas and especially locations with various underground and surface tanks used for storage of hazardous materials. The subsurface conditions vary at a site and the prediction of contaminant movement is a difficult task. This work focuses on the flow behavior of fluids in the porous media where drainage with prefabricated vertical drains (PVD) are used to flush the soils.
\end{abstract}


$-180-$ 


\section{TABLE OF CONTENTS}

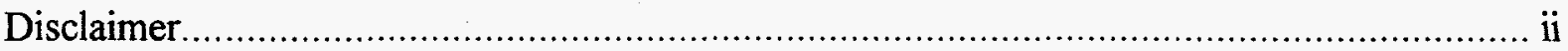

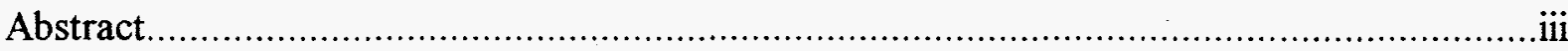

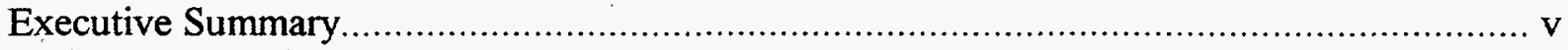

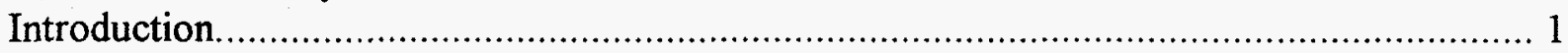

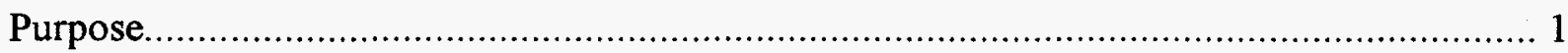

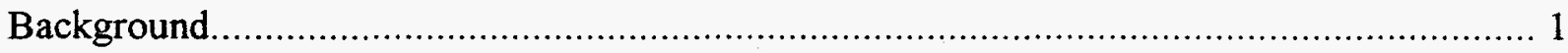

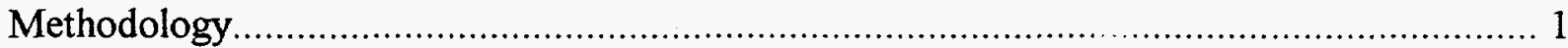

Work Performed This Period........................................................................................ 2

Work Planned for Next Period............................................................................. 2

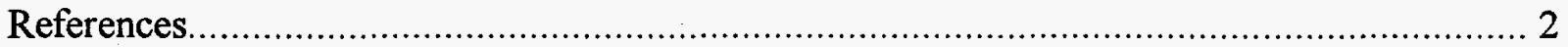


$-182-$ 


\section{EXECUTIVE SUMMARY}

This subtask was funded for the initial 60\% of the requested amount in mid March 1995. Presently, a literature search is initiated to gather information on the new developments in the area of subsurface contaminant movements. Some documents regarding available numerical models are collected. 



\section{INTRODUCTION}

Contaminations of the subsurface soils are problems encountered in many areas and especially locations with various underground and surface tanks used for storage of hazardous materials. Environmentally hazardous conditions are experienced when an existing container leaks or ruptures due to natural or man caused actions. As a result, the contents, defined as hazardous to health and attributed mainly to hydrocarbon derivatives, leak from their environment.

The subsurface conditions vary at a site and the prediction of contaminant movement is a difficult task. The plumes can partially be absorbed by soils as well as changing from one state to another through condensation or vaporization. The prediction of movements of these contaminants as a liquid or gas is a very difficult task due to the nature of the formations involved at a particular site. Additional difficulty results from the need for a knowledge of multiphase transport process that describes the movement of these chemicals.

\section{PURPOSE}

The purpose of this study is to investigate the flow mechanisms through different numerical models and to select at an existing model to study the subsurface flow mechanisms. The selected model will be used to predict the behavior of fluids in a laboratory scale contaminant recovery cell.

\section{BACKGROUND}

Fresh water aquifers are subject to contamination from a variety of activities such as spills of hazardous materials. When a spill occurs the fate of the contamination depends on many factors. The most important factor is the transmissibility property of the soils or permeable media. Proper knowledge and understanding of the heterogeneity of subsurface can provide a useful tool in understanding the fate and remediation of the contamination.

\section{METHODOLOGY}

A commercially available numerical model will be selected for the investigation of prefabricated vertical drains (PVD) on both laboratory and field scale investigation. Different grid designs will be considered for the representation of the experimental setup presently available in the West Virginia University's Civil Engineering laboratories. Some important soil properties that will be considered are porosity, thickness and conductivity of the porous medium, injection rates and subsurface fluid velocities, spacing between PVD's. 


\section{WORK PERFORMED THIS PERIOD}

This subtask was funded for the initial 60\% of the requested amount in mid March 1995. The researchers expect that the remaining $40 \%$ funded in April 1995. A literature search was initiated to gather information on the recent developments in the area of subsurface contaminant movements. The document regarding available numerical models for subsurface flow prediction was received from one source.

\section{WORK PLANNED FOR NEXT PERIOD}

The followings are planned for the next quarterly period:

1. The literature study will be continued.

2. A grid system suitable for numerical model studies will be prepared for the laboratory scale experimental setup.

3. Existing numerical models will be evaluated for their suitability in representing the experimental flow system.

\section{REFERENCES}

USEPA, "Determining Soil Response Action Levels Based on Potential Contaminant Migration to Ground Water: A Compendium of Examples," October 1989, EPA/540/2-89/057, Office of Emergency and Remedial Response, Washington, D.C. 20460.

USEPA, "Handbook on In-Situ Treatment of Hazardous Waste-Contaminated Soils," January 1990, EPA/540/2-90/002, Office of Research and Development, Cincinnati, OH 45628. 


\subsection{DEVELOPMENT OF A STANDARD PROTOCOL AND BARRIER DESIGN MODEL FOR IN-SITU FORMED BARRIERS (MC-26)}

Quarterly Technical Progress Report

for the period of

January 1, 1995 to March 31, 1995

Work Performed Under

Contract Number: DE-FC21-92MC29467

For:

U.S. Department of Energy

Morgantown Energy Technology Center

PO Box 880, 3610 Collins Ferry Road

Morgantown, WV 26507-0880

\section{Prepared by:}

West Virginia University

National Research Center for Coal and Energy

Department of Civil and Environmental Engineering

Department of Petroleum and Natural Gas Engineering

and

BDM Federal Inc. 
$-188-$ - 


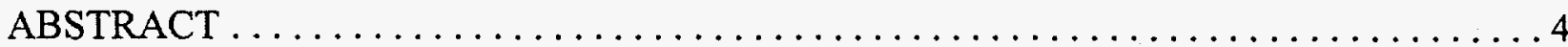

1.5.1 ADMINISTRATIVE REPORTING $\ldots \ldots \ldots \ldots \ldots \ldots \ldots \ldots \ldots \ldots \ldots \ldots \ldots$

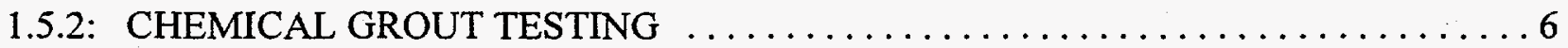

1.5.2.1: CHEMICAL GROUTS TO CONTROL LEACHATE $\ldots \ldots \ldots \ldots \ldots \ldots 6$

1.5.2.2: LARGE DIAMETER COLUMN TESTING $\ldots \ldots \ldots \ldots \ldots \ldots \ldots \ldots$

1.5.2.3: SAND RAIN DEVICE $\ldots \ldots \ldots \ldots \ldots \ldots \ldots \ldots \ldots \ldots \ldots \ldots \ldots \ldots \ldots \ldots \ldots$

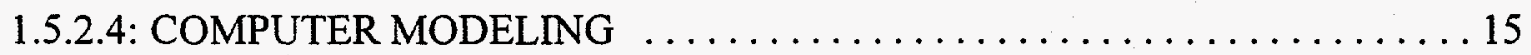

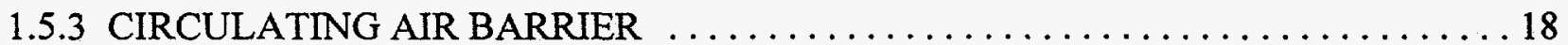

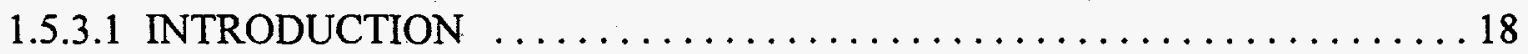

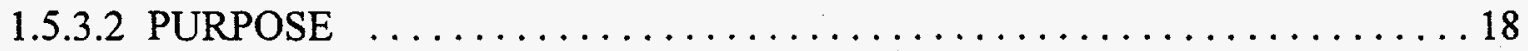

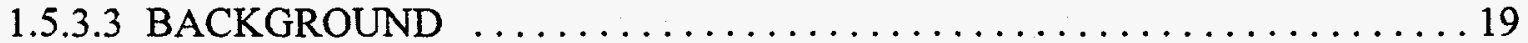

1.5.3.4 METHODOLOGY ................................. 19

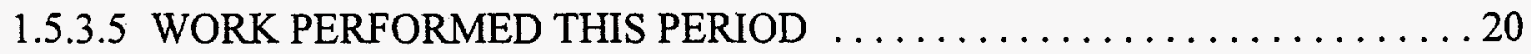

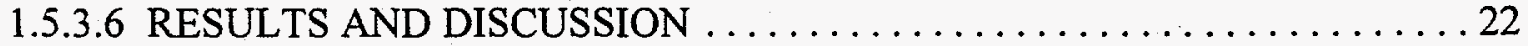

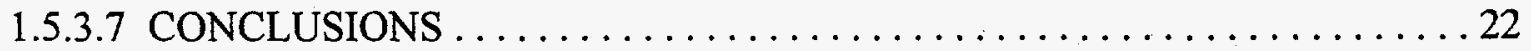

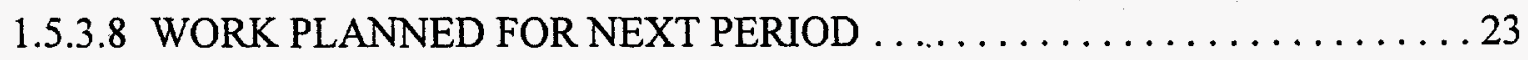

1.5.3.9 TECHNICAL/ADMINISTRATIVE DIFFICULTIES $\ldots \ldots \ldots \ldots \ldots \ldots 23$

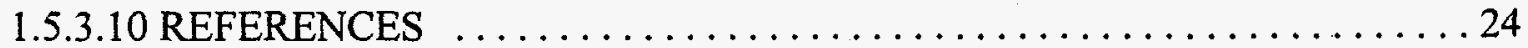




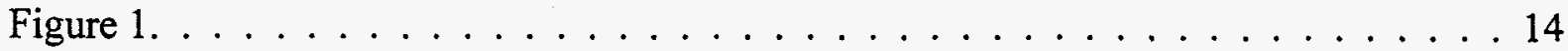

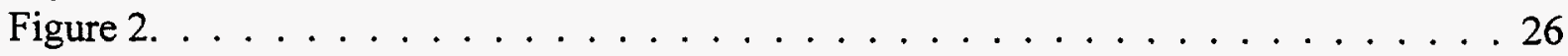

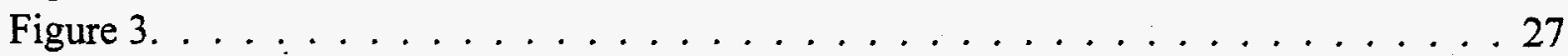

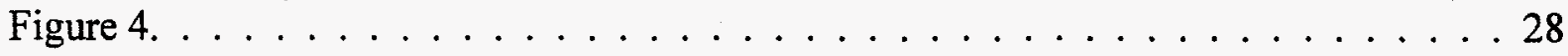

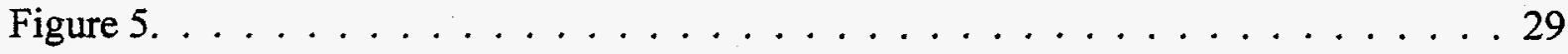

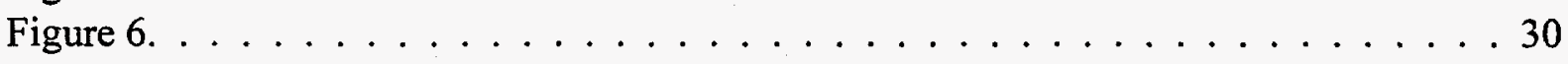

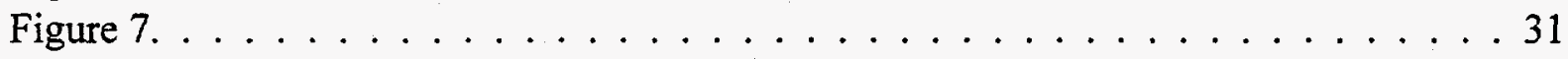

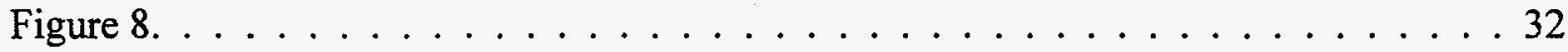

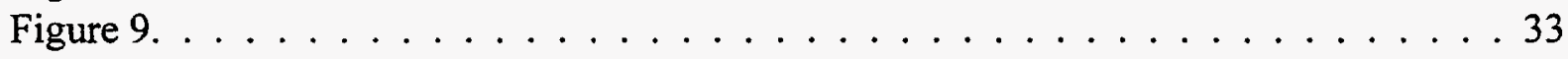

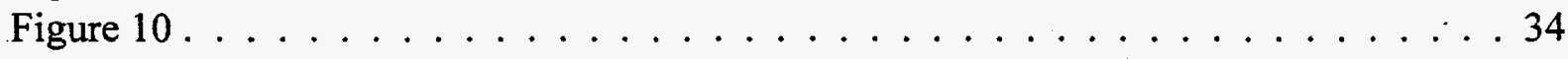




\begin{abstract}
Significant research effort is currently being conducted in the United States and the world for remediation of contaminated soils and groundwater. In parallel to remediation efforts, confinement technologies are needed to retard, or even prevent, the advancement of contamination plumes into the environment until the implementation of remediation efforts is completed. Research proposed herein aims at developing and investigating containment/confinement technology using desiccation and chemical grouts for in situ formation of barrier.
\end{abstract}

The desiccant barrier proposed to be investigated will be the recently developed circulating air barrier $(\mathrm{CAB})$. The $\mathrm{CAB}$ utilizes the injection of dry gas (air, nitrogen, $\mathrm{CO}_{2}$, etc.) to create an ultra dry zone in situ, beneath, or adjacent to the zone of contamination. The $\mathrm{CAB}$ relies on the removal (drying) of in situ liquids (water) so that any contaminating liquids entering the zone of desiccation must replace the previously removed liquids before the contaminants can migrate further. In field application, the CAB may be established by means of specific patterns of vertical or horizontal (or a combination of vertical and horizontal) injection and withdrawal wells which enable the injected dry gas to travel through and dry the formation prior to exiting via a withdrawal well.

The chemical grouts proposed to be investigated consist of urethane and divinyl polymers. The setting times of the grouts will be varied to enable optimum migration of the viscous fluid in the test soil, Ottawa sand. Column tests will be initiated to test the extent of migration and permeability of the grouts on a bench-scale. Phase II of this project will investigate the pilot scale injection of grout into a Grout Testing Cell that will be fabricated and installed in the B-17 facility.

This research will be conducted using laboratory and meso-scale setups. In addition to conventional laboratory equipment proposed research will utilize a large scale reactor for simulating in situ conditions. Conducting the research based on a meso-scale setup will minimize problems associated with scale effects. Such problems are usually encountered when a method is developed in the laboratory with no considerations given to correlation of laboratory scale results to field implementation. The B-17 facility in METC with its infrastructure will be utilized to conduct the proposed work. The proposed experimental methodologies will simulate field conditions and should provide laboratory data to test and enhance predictions of $\mathrm{CAB}$ and Chemical Grout performance made by existing models and computer simulations. 


\subsubsection{ADMINISTRATIVE REPORTING}

During this quarter the final version of the Construction Permit was submitted to Robert Romanosky, Chair, of the Laboratory Safety Committee at METC. Personnel at BDM Federal were instrumental in compiling the document and addressing the numerous comments from the Laboratory Safety Committee's December 22, 1994 review of the Construction Permits. This document took a quarter to reach the final version because of delays at METC in producing the design drawings and configuring ventilation system requirements. Once this document is signed researchers will begin moving existing equipment to Building 17. Additional equipment that is needed to perform experiments in B-17 will be designed and fabricated by EG\&G Technical Services of West Virginia. A Service Agreement is being initiated by WVU so that the project may reimburse $E G \& G$ for it's services. $E G \& G$ will be designing and fabricating two Circulating Air Barrier ( $C A B)$ vessels and five Chemical Grout testing cells. This equipment will be used to complete the bench scale experiments which have been initiated at WVU.

The research team presented the findings of the Literature Review to the METC COR (Rodney Giesbrecht) and other team members at the NRCCE on March 31, 1995. William Overby of BDM presented a thorough review of Generic Barrier Technologies and explained why the researchers chose to explored the $\mathrm{CAB}$ and the Chemical Grouts. The Chemical Grout graduate research assistants presented a brief background and explained results of preliminary . work. Dr. Khashayar Aminian presented the results of the literature review and a description of the principles of how the $\mathrm{CAB}$ functions and design of experimental apparatus to test the $\mathrm{CAB}$.

This document will report on the progress of Project MC26 under the WVU/METC Cooperative Agreement. The document is divided into three major sections. The first section contains Administrative reporting that will outline major milestones. The task schedule and progress will be presented as well as financial information. The project is managed by the Environmental Technology Division of the West Virginia University National Research Center for Coal and Energy. The second major section will report on the Chemical Grouting research being conducted by the West Virginia University Department of Civil and Environmental Engineering. The third section reports on progress of the $\mathrm{CAB}$ research that is being conducted by West Virginia University Department of Petroleum and Natural Gas Engineering and BDM Federal, Inc. A listing of key personnel below delineates persons responsible for each section.

Key Project Personnel:

Chemical Grout Principal Investigators:

Mohammed A. Gabr, Ph.D., P.E. ${ }^{1}$

Brian Reed, Ph.D., P.E.'

1 West Virginia University Researcher 
Research Assistants:

David A. Bolten ${ }^{1}$

Jacob S. Freshwater ${ }^{1}$

Edward L. Hakala ${ }^{1}$

Tara D. Judy ${ }^{1}$

James Moseley ${ }^{1}$

Circulating Air Barrier Principal Investigators:

Sam Ameri, Ph.D. ${ }^{1}$

Khashayar Aminian, Ph.D. ${ }^{1}$

Shahob Moghaghegh, Ph.D. ${ }^{1}$

David Locke, P.E. ${ }^{2}$

William Overby, C.P.G. ${ }^{2}$

Gregory Johnson, Ph.D. ${ }^{2}$
Research Assistants:

Darwin Molnar, Research Instructor ${ }^{1}$

Aleksandar Bugarski ${ }^{1}$

Edson Costa ${ }^{1}$

Salam Murtada'

Project Manager:

D. Courtney Black ${ }^{1}$

\subsection{2: CHEMICAL GROUT TESTING}

\subsubsection{1: CHEMICAL GROUTS TO CONTROL LEACHATE}

GRADUATE RESEARCH ASSISTANTS: Tara D. Judy and David A. Bolten

\section{RESEARCH OBJECTIVES:}

- Choose and evaluate various chemical grouts which exhibit properties making their use feasible in the development of a bottom seal at hazardous waste sites.

- Determine the chemical and physical properties of the grouts selected for further study.

- Characterize and develop the chemical grouts as a low permeability barrier to various chemicals and water.

- Conduct performance testing and establish systematic test protocol.

\section{PROJECT STATUS}

2 BDM Federal, Inc. Researcher 
Based on the literature review, a urethane gel and vinyl monomer grout were chosen for further testing. Immersion testing has been completed on both grouts to determine their reactivity in various harsh environments. At present, column permeability tests are being conducted on the grouts alone and on a mixture of sand and grout. Compression tests have also been conducted on a limited number of disturbed grout and sand mixtures to determine the each grout's compressive strength.

\section{Immersion Test Procedure}

1. Cast the grout molds and allow to cure for 1 hour.

2. Place the molds in various waste solutions for 24 hours. Immerse one specimen in deionized water as a control and comparison group

3. Towel dry each mold, photograph and measure (i.e., weight and volume).

4. Next, allow the specimens to dry for 20 hours.

5. After this drying period, re-photograph and record the physical characteristics of the molds.

6. Again immerse the grout specimens in there respective waste solutions for another 24 hours.

7. Repeat step 3.

8. Lastly, allow each mold to air dry for another 20 hours, after which their characteristics are recorded.

As mentioned in the second quarterly report, 10 acrylic columns and a stand have been manufactured to conduct batch permeability tests on the grout specimens. Each column is fitted with a porous stone to give stability and allow for adequate drainage. Permeability tests on the grout alone along with permeability test on a mixture of sand and grout are currently being conducted.

\section{Specimen Preparation Procedures For Permeability Testing}

\section{Pure Grout Specimens}

1. Place the fitted plastic cap in the clean out plug and tighten with wrench.

2. Mix a predetermined volume of grout.

3. Tilt the column and smoothly pour the grout in. Be sure not to damage the sand lift.

4. Allow the grout to dry for 1 hour for optimum curing.

5. Remove the plastic cap and replace with a porus stone.

6. Pour 1 liter of tap water into the column and let sit for 24 hours.

7. If no leakage is observed after the 24 hour time period, add an additional $15 \mathrm{~L}$ of water.

8. Monitor and record the change in the water head and outflow at regular intervals.

\section{Grout and Sand Specimen}

1. Place the fitted plastic cap in the clean out plug and tighten with wrench.

2. Place a reweighed amount of sand in the column following the ASTM standard for 
minimum density.

3. Calculate the pore volume of the sand lift.

4. Prepare a pore volume amount of grout.

5. Tilt the column with care to reduce disturbance of the sand lift.

6. Pour the grout solution down the side of the column and allow to permeate through the sand.

7. Allow to cure for 1 hour.

8. Pour 1 liter of tap water into the column and let sit for 24 hours.

9. If no leakage is observed after the 24 hour time period, add an additional $15 \mathrm{~L}$ of water.

10. Monitor and record the change in the water head and outflow at regular intervals.

\section{Compression Testing}

Due to the characteristics of the grout, compression tests on grout alone could not be conducted. Therefore a sand and grout mixture following the ASTM standard for chemically grouted soil was made to conduct the compressive test. These specimens were made in triplicate to assure accurate results and performed in accordance to ASTM Method D 4219 - 18.

\section{$\underline{\text { Results }}$}

As mentioned earlier, immersion tests have already been conducted on both grouts, and have been meet with mixed results. Both the vinyl monomer and the urethane gel shrink when exposed to the air and swell when in contact with water. The urethane gel floated in all waste solutions while the vinyl monomer did not float in any of the studied waste solutions. Sodium hydroxide had adverse affects on both grouts. Sodium hydroxide turned the urethane dark brown and soft and made the vinyl monomer turn a dark brown color with very little structural integrity.

Permeability testing on the vinyl monomer grout alone and the sand and grout mixtures are currently being performed. In the initial stages, the vinyl monomer grout alone has proven to have a very low permeability $(\sim 0)$. Do to the toxicity and the limited supply of the urethane, the urethane gel permeability testing has not commenced.

All the compression test on the vinyl monomer grout with sand yielded similar results. Failure occurred at a stress rate of $21441.9 \mathrm{KN} / \mathrm{m}^{2}$ at a strain of $11 \%$.

\section{PROBLEMS:}

The development of a water-tight seal in the column tests has been difficult. Minor modifications and new materials may be required for correction.

\subsubsection{2: LARGE DIAMETER COLUMN TESTING}




\section{RESEARCH OBJECTIVES:}

- Establish and develop a testing protocol for evaluation of various chemical compounds as a permeation grout for forming in-situ barriers.

- Evaluate the performance of these grouts as a barrier to plume migration.

- Determine the durability of these grouts when exposed to chemical agents.

- Determine the structural integrity of the grout by simulating in-situ stress conditions.

\section{PROJECT STATUS:}

The establishment of a standard testing procedure/protocol for evaluating various grouts as a barrier to plume migration is approximately $80 \%$ completed. Trial grouting experiments have began on the $3 \mathrm{M} 5610$ urethane gel and are showing encouraging results. Both of these issues are further discussed in the following sections.

\section{Testing Procedures}

As mentioned in prior reports, the specimen preparation procedure has been developed. This method allows for the study of the Ottawa sand at a minimum density $\left(94.8 \mathrm{lb} / \mathrm{ft}^{3}\right)$ and a maximum density $\left(111 \mathrm{lb} / \mathrm{ft}^{3}\right)$ (through use of a vibratory plate). These two conditions bound the densities likely to be encountered in the field. At a minimum density, a grout should be easier to inject into the soil media, but the permeability exhibited by the sand will be higher. When the soil is at a maximum density, the media will be less groutable and display a low permeability. The adapted methods utilized in obtaining these densities are outlined below.

\section{A. Minimum Dry Density Procedure}

1. Wipe the test vessel clean

2. Record the diameter of the vessel and the injection well

3. Using a permanent marker, make a ring around the inside of the column 18 inches from the bottom of the interior base to represent the final desired specimen height.

4. Place the geonet in the bottom of the column, followed by the geotextile

5. Insert a $181 / 4$ inches piece of 5/8 inch O.D. tygon tubing inside the injection well and connect static mixing tube hand tight.

6. Position the injection well in the center of the column approximately 1 inch from the base plate.

7. Weigh out $6 \mathrm{~kg}$ of the Ottawa sand and record on the Specimen Preparation Data Sheet

8. Gently place the sand in the column using a small container. The drop height of the sand should be at a minimum (approximately zero)

9. Repeat steps seven and eight until the specimen height is obtained 
10. Remove the tygon tubing from the injection well and reconnect the static mixing tube.

11. Calculate the density of the sand. This value should be within $5 \%$ of the actual minimum density $\left(94.8 \mathrm{lb} / \mathrm{ft}^{3}\right)$ obtained through the ASTM method.

\section{B. Maximum Dry Density Procedure}

1. Wipe the test vessel clean

2. Record the diameter of the vessel and the injection well on the Specimen Preparation Data Sheet

3. Using a permanent marker, make a ring around the inside of the column 18 inches from the bottom of the interior base to represent the final desired specimen height.

4. Place the geonet in the bottom of the column, followed by the geotextile

5. Insert a 181/4 inches piece of 5/8 inch O.D. tygon tubing inside the injection well and connect static mixing tube hand tight.

6. Weigh out $6 \mathrm{~kg}$ of the Ottawa sand and record on the data sheet.

7. Put the injection well through the center hole of the vibratory plate. Lift and hold

8. Position the injection well in the center of the column approximately 1 inch from the base plate.

9. Pour in the preweighed sand and level the lift using a straight edge

10. Lower the vibratory plate onto the lift

11. Connect the vibratory plate to the power cord

12. Start vibration and record the start time on the data sheet

13. Vibrate for two minutes

14. Add and level out the next sand lift, then repeat the procedure until desired specimen height is obtained.

15. Remove the tygon tubing from the injection well and reconnect the static mixing tube.

16. Calculate the density of the sand. This value should be within $5 \%$ of the actual minimum density $\left(111 \mathrm{lb} / \mathrm{ft}^{3}\right)$ obtained through the ASTM method.

Preliminary testing of the chemical grouts will be in unsaturated conditions. At these conditions, dilution effects can be neglected and the integrity of the grout bulbs will be increased. Later studies will be performed at saturated conditions to account for the presence of water.

Once the specimens are properly prepared, groutability tests commence. These tests are performed to address the ability of the chemical grout to be injected into the soil media. Factors such as: viscosity, gel time control, ease of grout preparation, and injection rates.

\section{Groutability' Testing Procedure}

1. Record the pertinent initial data on the Groutability Testing data sheet

2. Ensure that the well insert piece is removed

3. Set pump to desired flow rate $(0-4 \mathrm{~L} / \mathrm{min})$ and tubing size (26) 
4. Fill one small bucket (approximately 2 gallons) with tap water (Bucket \#1)

5. Fill another small bucket (Bucket \#2) with approximately $1 \mathrm{~L} 50 \% \mathrm{w} / \mathrm{w} \mathrm{NaOH}$ and tap water

6. With the injection line disconnected from the well, take the component lines and place in the bucket containing only the tap water.

7. Check to ensure the component valves are set correctly

8. Prime the injection system with the water

9. At this point, if the grout is batch mixed, the components should be mixed together, time recorded, and the other end of the injection line placed in the grout. If in-line mixed, the component lines are placed in the respective containers.

10. Record the initial amounts of the grouts.

11. Prime the injection system with the grout and displace the water in the line

12. Connect the injection line to the well assembly at the static mixing tube

13. Open the well valve

14. Push start on the pump and record initial time

15. If applicable, at two minute intervals, record the grouting pressures on the data sheet

16. Continue pumping until one of the following cases occurs:

i) the grout is observed around the entire circumference of the acrylic tubing

ii) the grout begins to short-circuit through either the top or bottom of the specimen

iii) a marked increase in the injection pressure is observed

iv) the viscosity of the grout is too high (i.e. approaching the gel time)

17. Push stop on the pump and record the time.

18. Disconnect from the static mixer and place the line in a 5 gallon bucket

19. Transfer the component line(s) to Bucket \#2 and restart the pump

20. Flush the pumping system, and if necessary, disassemble the connections and clean individually

21. Measure the amount of grout injected and record

One concern during this stage of testing, is the emission of health threatening gases. In particular, the $3 \mathrm{M} 5610$ urethane grout which is comprised of toluene 2,4-diisocyanate with an exposure limit of $0.005 \mathrm{ppm}$ and toluene 2,6-diisocyanate also with a 0.005 exposure limit. To reduce the risk to health, exposure to the compounds will be minimized through the use of a local exhaust system and a contained injection system. The initial measurements of the compound components will require a hood. Once placed in the proper container and sealed, it is transferred to the mobile injection station. The components will be positioned in a acrylic containment box connected to the exhaust system. The component lines will be connected and injection of the grout will commence. Upon completion of the injection process, the containers will be resealed and properly transported and disposed of. Spill kits will be readily available through the duration of this stage of study.

After the appropriate curing time (typically less than 6 hours), the effectiveness of the chemical grout to develop an impermeable seal within the large diameter column is investigated. Initially, it was thought that the vinyl tanks located in B-17 could be utilized for this phase of testing; however, after meeting with METC employees and observing the tanks identification 
plates, an alternative design was deemed necessary. The plates on these tanks clearly stated that they are not to be utilized for pneumatic hydrostatic purposes and gaining approval for their use would be difficult. The new permeability testing method will involve the use existing on-site water pressure. In short, METC water line pressure is approximately $70-80 \mathrm{psi}$, above what will be required for testing. This water pressure will be decreased through use of a precision regulator. The regulator's, which were recently received, can be set to a minimum outlet pressure of $2 \mathrm{psi}$ and a maximum of $15 \mathrm{psi}$. By setting the head pressure to a set value, a constant head permeability test can be performed. The volume permeating through the columns will be measured with time and a value for the permeability calculated. The resulting effluent liquids will be analyzed for base compounds of the chemical grouts, which in turn, would show disintegration of the grouting material. Breakthrough experiments will also be performed utilizing a tracer (e.g., chloride) which also require analytical work. This permeability testing method should prove much simpler to operate and yield more reliable results than the technique. A detailed procedure for performing these tests will be provided at a later date.

Upon completion of the permeability testing, a Post-Grouting phase of testing will begin. In these tests and the final grout bulb characteristics (i.e., bulb dimensions, photography, etc) and properties (i.e., compressive strength) are evaluated. ASTM Method D 4219 - 83 Standard Test Method for Unconfined Compressive Strength Index of Chemical-Grouted Soils is adhered to. Because these tests require the utilization of a loading machine, these experiments will need to be conducted off-site at WVU Geo-Environmental Laboratories

$\underline{\text { Results }}$

As relayed earlier, groutability tests have began. Only the 5610 urethane gel has been injected due to a limited amount of the Duraseal (vinyl monomer) in stock. A new shipment of the Duraseal is expected to arrive any day.

The urethane has been injected three times in batch mixes. The preliminary testing showed that the gel time was too fast (i.e., less than two minutes) to allow injection by batch mixing unless the gel time extender was used as a replacement. The initial test utilized a . minimum density specimen with the vibratory plate as a surcharge $(653 \mathrm{~g})$ and a $6: 1$ ratio of extender to gel. The two components were mixed and injection immediately began. After two minutes the gel became too viscous for pumping and injection ceased. The entire system was fouled with the grout; however, when disassembled, the entire system proved to be easily cleaned. The flow rate was $1.5 \mathrm{~L} / \mathrm{min}$ and no injection pressures were observed. The resulting grout bulb was spherical with a $102 \mathrm{~mm}(4 \mathrm{in}$.) diameter. No core samples were taken.

To increase the gel time, the gel time extender was refrigerated for 1.5 hours prior to mixing. The same surcharge and 6:1 ratio were utilized. The flow rate was increased in this test to $3 \mathrm{~L} / \mathrm{min}$ to increase grout delivery. Grouting operations were ceased when the grout shortcircuited at the top of the sample beside the well with approximately $1.5 \mathrm{~L}$ of the compound injected. The gel time proved to be greatly increased by chilling the extender to 10 minutes. 
This allowed the entire system to be flushed and cleaned. The bulb had a height of $267 \mathrm{~mm}$ (10.5 in.), a diameter $191 \mathrm{~mm}$ (7.5 in.), and was very symmetric. The bulb was also present around the well where there were no perforations (i.e., the grout did not migrate radially in a horizontal direction only from the well pattern). A core sample was taken on the vertical axis and subjected to a compression test. Failure of the sample was observed at a stress of 13468 $\mathrm{kN} / \mathrm{m}^{2}$ and a strain of $6.6 \%$

The final test was performed utilizing a 10:1 extender to gel ratio. The extender was again chilled prior to mixing and the surcharge remained the same. $3.3 \mathrm{~L}$ of the grout was prepared. The initial injection rate was $2.0 \mathrm{~L} / \mathrm{min}$, but was increased to $3.25 \mathrm{~L} / \mathrm{min}$ with no observed injection pressures. The gel time was increased sufficiently to permit the entire volume of the grout to be injected into the specimen and allow for system flushing. Upon exhaustion of the grout mixture, grout operations were terminated. This bulb was $330 \mathrm{~mm}$ (13 in.) in height and $241 \mathrm{~mm}(9.5 \mathrm{in}$.) in diameter (i.e., to develop a complete seal within the column, 2 more inches are required). In this test, two core samples of the bulb were obtained: one sample on the $\mathrm{Y}$-axis (vertically) and another on the $\mathrm{X}$-axis (horizontally). Both were tested for compressive strength and yielded varying results. The vertical sample failed in compression at a stress of $8701 \mathrm{kN} / \mathrm{m}^{2}$ and a strain of $13.1 \%$, while the horizontal sample reached failure at values of 3972 $\mathrm{kN} / \mathrm{m}^{2}$ and $9.8 \%$.

\section{PROBLEMS:}

No problems or difficulties have arose.

\subsubsection{3: SAND RAIN DEVICE}

GRADUATE RESEARCH ASSISTANT: James Moseley

\section{RESEARCH OBJECTIVES:}

- Construct a device that will produce a uniformly dense sand sample for large-scale grout testing.

\section{PROJECT STATUS:}

The literature review process is underway and should be done within two weeks. Communication with Romish and EG\&G is encouraging. An initial idea of what the sand rain device might look like was conveyed to them and they are confident they can fabricate a satisfactory device.

It was decided that a prototype was not to be built, so the next step is a measured drawing.

$\underline{\text { Results }}$ 
A review of the literature revealed that there have been several sand rain devices (a.k.a pluviators) that have already been designed and built. Results with these have been quite good when using uniform sand. Pluviators are more desirable than vibratory methods because

\section{Sand Pluviator}

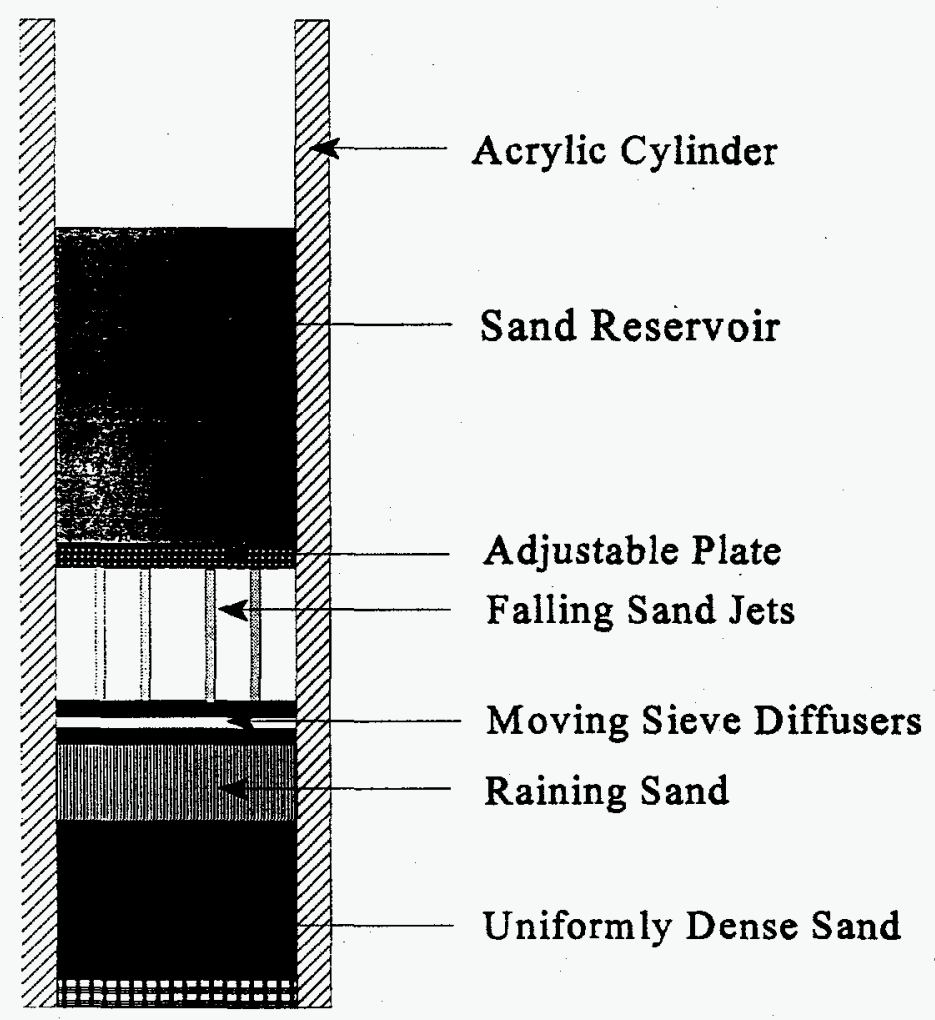

\section{Figure 1 Typical Sand Rain Device}

vibrating tables tend to crush about $2 \%-9 \%$ of the sand particles so that they are reduced in size. Also, a wide range of densities can be achieved as well as more accurate measurements of those densities. Presented in Figure 1 is a typical sand rain device.

Research in the field now has turned to achieving the same results with other types of soil. With sands containing greater than $2 \%$ fines, problems occur with the typical configuration because of the radical differences in particle characteristics. The fine particles tend to segregate and stay in the air since they reach terminal velocity much sooner than the sand particles. The fine particles also tend to clog the sieves and disallow a uniform rain which causes radical differences in relative densities. Experiments done in a vacuum have achieved only marginal 
improvements.

Two methods that have been introduced in the past two years to overcome these difficulties are (1) a consolidation procedure and (2) a newly designed sand rain device. The consolidation procedure is done simply by forming a slurry in the large scale testing mold and performing a consolidation test to force out most of the water. The consolidation procedure approximates actual in-situ conditions well and density can be varied widely. The biggest drawback to this procedure is each sample takes about 18-20 days to form a single specimen

The second method involves changing the raining procedure in a typical device. Instead of using an adjustable plate, a plate with a long thin slit is used to allow passage of the sand from the reservoir. This slitted plate is allowed to move back and forth while raining sand and moving up so the drop height is constant. According to the research, this eliminates the need for diffuser sieves. This looks like a promising alternative to the standard design if other soils are eventually to be tested.

\section{PROBLEMS:}

No problems have arisen.

\subsubsection{4: COMPUTER MODELING}

GRADUATE RESEARCH ASSISTANT: Edward L. Hakala

\section{RESEARCH OBJECTIVES:}

--Adapt BGROUT to model specific meso-scale grout injection experiments.

--To effectively use COLORGRID in analyzing output created by BGROUT.

--Using the revised model, investigate grout injection strategies.

\section{PROJECT STATUS:}

The program BGROUT has been successfully executed using data formatted to resemble the confinement project's meso-scale experiments. Initial input data for BGROUT was provided by Walt $\mathrm{K}$. Sawyer and subsequently modified to match the confinement project's parameters.

Initial estimates of the grout penetration radius were made using the following data: grout with a viscosity of $5 \mathrm{cp}$; GTC diameter of 3 feet; permeability of the sand at 1000 millidarcy; and injection pressure of $23 \mathrm{psi}$. These variables are easily modified to allow for prediction of optimum settings. All other variables are set to typical values, as estimated by Mr. Sawyer, and may also be modified. With this initial setting, the penetration radius of the grout was determined to be 0.880 feet from the injection site. Several other executions were made using different data to see what kind of 
effects those changes would make. Initial estimates for a grout of viscosity $10 \mathrm{cp}$ did not significantly change the results from the initial estimates using a grout of viscosity $5 \mathrm{cp}$.

\section{PROBLEMS:}

In order to accurately model the meso-scale experiments the value of several variables must first be known. Some of the values needed include the initial viscosity of the grout, the grout set times, and the permeability of the medium. Although these values are needed to more accurately model the experiments, they can be estimated in the initial executions of BGROUT.

The results obtained from BGROUT are graphically analyzed using a program called COLORGRID. This program does not have printing capabilities and only gives graphical displays. Therefore, all plots or graphs created to facilitate the interpretation of the results must first be manually copied, then transferred to a spreadsheet and manipulated and printed from there. 


\section{FLOW CHART OF COMPUTER MODELING}

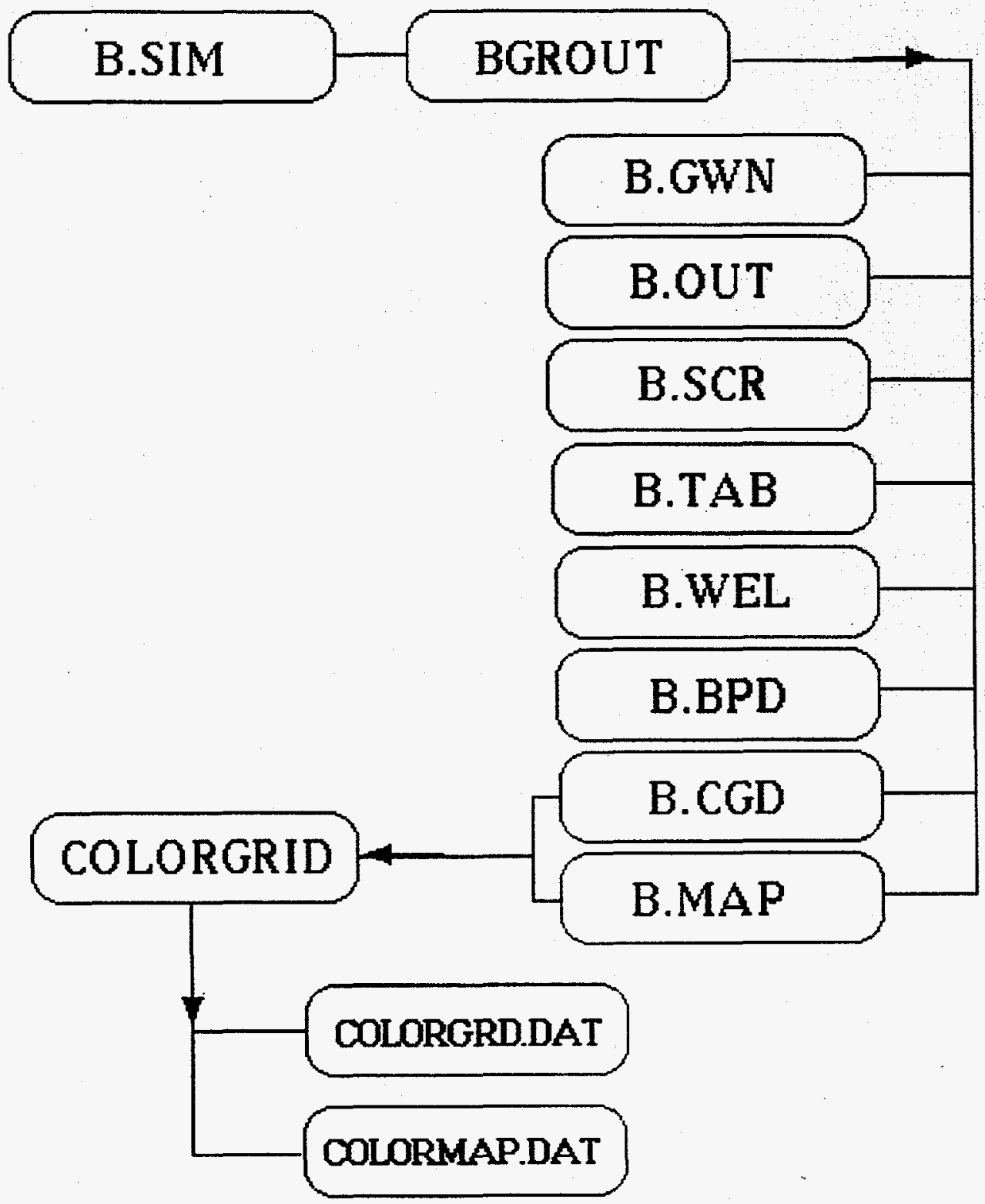




\subsubsection{CIRCULATING AIR BARRIER}

\subsubsection{INTRODUCTION}

Many contaminated subsurface sites can not be economically decontaminated because of the limitations in technologies for decontamination. In such cases, containment becomes the primary technology for environmental protection. For non-excavatible sites, in situ containment is the most viable approach for preventing further spread of contamination. Different approaches for achieving in situ containment have been proposed; however, the study herein is focused on the evaluation of in situ barriers created by soil desiccation.

The desiccant barrier proposed to be investigated is the recently developed $(1,2)$ Circulating Air Barrier ( $\mathrm{CAB}$ ). $\mathrm{CAB}$ utilizes the injection of dry gas into a porous media to create an ultra dry zone in situ by removing water and reducing the water saturation below the level required for liquids to flow in order to prevent migration of underground contaminants. $C A B$, once established, will also provide a means of monitoring and removing contaminants entering the zone. The proposed experimental methodology should provide laboratory data to test and enhance predictions of $\mathrm{CAB}$ performance made by existing models and computer simulations.

\subsubsection{PURPOSE}

The concept of the Circulating Air Barrier was conceived $(1,2)$ to solve the subsurface contamination problems at the Hanford site used by the former Atomic Energy Commission. The references to $C A B(1,2,3)$ are mainly related to $C A B$ as a concept, and no field or laboratory data is available in the literature. The previous studies $(1,2)$ concluded that a CAB system provided many advantages, however, the concept needs to be demonstrated to develop data necessary for scale-up and regulatory acceptance.

Among issues that must be settled before it can be decided if CAB technology is applicable to all DOE sites are the influence of the soil characteristics (such as, porosity, permeability, water saturation, grain size distribution, and clay content) on the drying profile and $\mathrm{CAB}$ performance. The laboratory study to be undertaken will evaluate the soil characteristics influence on CAB performance and will determine the effects of flow and sweep efficiency for fixed and mixed grain size soils. These experiments will validate and/or improve model predictions of system behavior and drying profiles of different soil types. 


\subsubsection{BACKGROUND}

The Circulating Air Barrier (CAB) system is a desiccant-type barrier designed to prevent the movement of liquid contaminants toward groundwater, using air circulation and a processing system to lower water saturation in a targeted subsurface zone. The concept of Circulating Air barrier was introduced in a study (1) that evaluated the barrier systems that could be installed beneath and around the tank farms with a minimum of excavation at DOE's Hanford Site. The $\mathrm{CAB}$ can be installed using either vertical or horizontal wells, establishing a pattern of air injection and extraction wells. The moving air vaporizes water in the zone and carries the water vapor to extraction well. In time, circulation of the air reduces the water saturation in the swept interval, and continues to remove, by evaporation, liquids that move into the zone such as a leaked plume. No liquids can flow through this interval until a critical saturation is achieved, a saturation level that is well above the initial saturation. In the event that a leak occurs, the CAB system serves as a tool for early leak detection and provides a means to withdraw volatile contaminants for surface treatment. The study concluded that $\mathrm{CAB}$ system provided many advantages including non-physical confinement, active monitoring and leak detection, commercially available oil and gas technologies and equipments, emergency response and rapid deployment capability, and high potential for integration with other remediation technologies. However, the concept needs to be demonstrated to develop data needed for scale-up and regulatory acceptance.

A follow up study by $\mathrm{K} \& \mathrm{M} / \mathrm{BDM}$ (2) which addressed modeling, cold test design, and surface processing and control design for the $C A B$ demonstration at Hanford concluded that several issues must be settled before it can be decided if CAB technology is applicable to all DOE sites. Key among these issues is the influence of the soil characteristics such as porosity, permeability, water saturation, grain size-distribution, and clay content on the drying profile and $\mathrm{CAB}$ performance. This report further recommended a laboratory study to be undertaken to evaluate the soil characteristics influence on $C A B$ performance and to find out the effects of flow and sweep efficiency for fixed grain-size and mixed grain-size soils. This would also serve to validate and/or improve model predictions of system behavior and drying profiles of different soil types. In addition, a range of geologic and climatic environments within which the $C A B$ could successfully operate, baseline equilibrium moisture curve for a specific grain-size, and relative humidity for a specific temperature.

\subsubsection{METHODOLOGY}

Experimental procedures will be developed to address the problem of evaluating a desiccant barrier, i.e. a barrier based on creation of a dry zone of earth beneath a contaminated zone to store contaminating liquids, thus preventing their further migration. Two phases of experimental research are proposed in this study. The B-17 facility in METC with its infrastructure will be utilized to conduct the proposed work. The first phase deals with bench-scale experiments using laboratory setups. The second phase will deal with a meso-scale setup that will utilize large tanks for simulations of in situ conditions in order to minimize problems associated with scale effects. 
Bench-scale testing of the $\mathrm{CAB}$ process parameters will utilize sand packs to determine the relationship between soil characteristics and in situ barrier quality. Sand packs will be calibrated to determine porosity, permeability, and saturation characteristics. The soil characteristics will be varied by changing grain size and sorting of the pack materials. Residual water saturation of the pack will be established by first saturating the pack with water and then desaturating the pack by injection of water-saturated air. The pack will then be dried at various rates of air injection to determine drying characteristics as a function of rate, remaining water saturation, and soil characteristics. The final phase of sand pack testing will be to resaturate the packs with simulated contaminant fluids injected at low pressure (near atmospheric) at the top while monitoring any effluent at the bottom. This will allow determination of contaminants migration rate as well as total storage capacity of the packs.

Meso-scale performance testing will be used to investigate the effectiveness of the $C A B$ system in containment/confinement of the study waste under simulated field conditions. The mesoscale tests of the CAB system will utilize large rectangular tanks in DOE/METC's B-17 building to create a three-dimensional test bed to verify, refine, and extrapolate the results of sand pack experiments to field like conditions. The tanks will be filled to a desired depth by slurring sand of predetermined grain size range into the tanks with water. All or part of bed will then be desaturated, dried, and "contaminated" with safe liquid to simulate the CAB process on the mesoscale. Instrumentation and sampling ports and tubes will be placed in strategic locations in or at the tanks to monitor the status of the CAB.

\subsubsection{WORK PERFORMED THIS PERIOD}

\section{Task 1: SARS Activity}

Detailed $C A B$ vessel assembly drawings were submitted to METC personnel on 01/25/95 for re-drawing as per METC requirements. As of 04/07/95, these drawings have not been completed. A meeting with a METC equipment group was attempted, however, they require METC drawings prior to such a meeting. A draft of the 'Operating Plan' requirements has been completed, however, its editing and consummation is dependent upon final $C A B$ vessel assembly design as per official METC drawings.

\section{Task 2.1: Literature Review}

As stated above, a comprehensive literature review relative to $\mathrm{CAB}$ was conducted and completed during previous quarters and reported earlier. A presentation relative to the results of the literature review was given on 03/31/95.

Additional literature searches relative to procedures and instrumentation for measuring and monitoring air humidity, soil moisture, and permeability have been continued during this quarter. The key issue in the selection of the instruments is minimum intrusion in the sand-pack or CAB bed 
to avoid influencing the air flow path.

\section{Task 3: Laboratory Equipment and Preliminary Testing}

The air-water equilibrium plays a critical role in the $\mathrm{CAB}$ design and development. While there are published data for air-water equilibrium, they are not obtained in the porous media. Consequently, it is important to investigate the influence of porous media on both gas-water equilibrium and mass transfer from liquid phase to gas phase. Two sets of preliminary experiments have been designed. These experiments are described below.

\section{Sand-pack Tests}

The effect of dry air on an unconsolidated porous medium at irreducible water saturation will be investigated during these set of experiments. The main portions of these experiments will be conducted at the B-17 Building at METC utilizing the CAB vessel assembly. However, a series of preliminary experiments have been designed for calibration of test equipment and to evaluate the protocols for determining sand pack properties. These preliminary experiments have been performed at WVU/PNGE laboratories.

A sand-pack chamber, as illustrated in Figure 1, has been designed and manufactured to identify the most feasible method of determining sand-pack properties, namely, optimum sand moisture content (water saturation) for compaction, porosity, and permeability. To date, the optimum moisture content for packing ASTM 20/30 mesh sand that conforms to ASTM designation $\mathbf{C} 778$ has been determined using a modified 'Standard Ordinary Compaction Test' ( see Figures 2 and 3). The procedure and experimental setups for determining sand-pack porosity and permeability have been developed ( see Figures 4 and 5). The measured porosity values based on the method have found reasonable repeatability, however, more testing is required to assure repeatability. Permeability measurement instrumentation and techniques are currently being evaluated for accuracy and repeatability.

\section{Core Tests}

The effect of porous media on air-water equilibrium has been investigated utilizing Berea sandstone core samples. It should be noted that a consolidated porous media, such as a Berea core sample, does not represent the typical soils at DOE Sites. However, these series of experiments will provide a foundation for evaluating the influence of porous media on air-water equilibrium when the media is at irreducible water saturation. Also, these experiments will provide a lower limit for sand-pack experiments while the published air-water equilibrium will serves as a upper limit.

The designed experiments are implemented to first fully saturate the core sample with water (see Figure 6). Then, the core saturation is reduced to minimum water saturation by displacing the water by water vapor-saturated air ( see Figure 7). Finally, dry air is injected into 
the core sample to attain a certain pressure and then released to evaluate the increase in humidity (see Figure 8). These experiments will assist in evaluating the effect of porous media on air-water equilibrium. For calibration purposes, an experimental setup has been designed to investigate the accuracy of the experimental apparatus and procedures for air-water equilibrium measurements (see Figure 9). To date several experiments have been completed, however, equipment failures has led to alternate measurement procedures and purchase of additional equipment.

\subsubsection{RESULTS AND DISCUSSION}

\section{SARS Activity}

The draft form of the 'Operating Permit' is completed and should submitted for METC approval during the next quarter.

\section{Sand-Pack Tests}

The optimum water saturation for compaction of ASTM 20/30 mesh sand has been determined to be 8 per cent. Porosity values vary by approximately 3 per cent, which indicates reliability of the procedure. Permeability measurements methods need to be re-designed in order to quantify the repeatability of the compaction technique.

\section{Core Tests}

The core saturation and desaturation experiments have been successfully performed and verified by our previous measurements of porosity, permeability and minimum water saturations. The dry experiment deals with minute volumes of air and water and, as a result, the experimental procedures and instrumentation have been continuously modified to conform within the measurement ranges of existing equipment and instrumentation.

\subsubsection{CONCLUSIONS}

\section{SARS Activity}

The next phase of SARS Activity is completion of the 'Operating Permit'. Completion of this document is contingent upon receipt of the 'official' METC drawings.

\section{Sand-Pack Tests}

The sand-pack tests are useful in establishing experimental protocols and identifying the necessary instrumentation for $\mathrm{CAB}$ vessel assembly experimentation that will be conducted at DOE/METC's B-17 Building.

\section{Core Tests}


The core tests can provide a foundation for evaluating the influence of porous media on air-water equilibrium.

\subsubsection{WORK PLANNED FOR NEXT PERIOD}

\section{SARS Activity}

Continue assisting METC personnel in the finalization of 'official' drawings for METC 'Operating Permit'. Upon completion of drawings, meet with METC equipment group, determine appropriate instrumentation for $\mathrm{CAB}$ experiments, and order necessary equipment. Upon completion of drawings, edit and finalize 'Operating Plan' for 'Operating Permit'. Submit 'Operating Permit' for METC approval and, as per METC instructions, submit drawings for construction of $\mathrm{CAB}$ vessel assemblies

\section{Sand-Pack Tests}

Continue packing sand as per modified 'Standard Ordinary Compaction Test' measuring porosity and permeability and determine repeatability of experimental procedural techniques. Order equipment necessary to evaluate additional compaction techniques. Evaluate additional compaction techniques by determining repeatability of experiments by porosity and permeability measurements.

\section{Core Tests}

Complete air-water equilibrium experiments in Berea sandstone core samples. Initiate mass transfer experiments in Berea sandstone core samples.

\subsubsection{TECHINICAL/ADMINISTRATIVE DIFFICULTIES}

As stated earlier, detailed drawings of the CAB vessel assembly were submitted to METC personnel on 01/25/95 and to date have not been completed. A meeting with the METC equipment group, finalization of the draft 'Operating Plan', ordering and purchase of materials and equipment, and actual construction of the $C A B$ vessel assemblies are contingent upon receipt of these drawings. 


\subsubsection{REFERENCES}

1. K\&M/BDM: "Evaluation of Alternative Drilling Technologies and Subsurface Barriers for Single Shell Tanks at Hanford", Report Prepared for USDOE/METC under Contract No. DE-AC21-90MC27346, Phase I: Feasibility Assessment Jan. 1993 and Phase II: Implementation Plan Development Nov. 1993.

2. K\&M/BDM: "Design of Circulating Air Barrier System for Cold Tests at Hanford", Volume I - Draft Report Prepared for USDOE/METC under Contract No. DEAC21-90MC27346, Task 23, July 30, 1994.

3. Thompson, B.M., C.E. Morris, J. Stormont, M.D. Anesky: "Development of Dry Barrier for Containment and Remediation of Waste Sites", Proceedings of Waste Management 94 Symposia, Vol. III, pp. 2193-2198.

4. Robert E. Treybal: Mass Transfer Operations, Second Edition, McGraw-Hill Book Company, 1968.

5. H.C. Slider: Worldwide Practical Petroleum Reservoir Engineering, PennWell Books, 1982.

6. C.H. Ikoku: Natural Gas Production Engineering, McGraw-Hill Book Company, 1983.

7. Katz and Coats: Underground Storage of Fluids, Ulrichs Books Inc., Ann Arbor, Mich., 1975.

8. Katz et al: Handbook of Natural Gas Engineering, McGraw-Hill Book Company, 1959.

9. $\quad$ "Compaction Tests", Chapter 6: Manual of Soil Laboratory Testing, Vol. 1, John Wiley and Sons, 1978.

10. ASTM Committee D-18: "Standard Test Methods for Moisture-Density Relations of Soil, Rock, and Soil-Aggregate Mixtures using $5.5 \mathrm{lb}$ Rammer and 12-inch Drop", from Annual Book of ASTM Standards, Section 4, Vol. 04.08, 1991.

11. ASTM Committee D-18: "Test Methods for Moisture-Density Relations of Soil (D698)", Proceeding for Testing Soils, Fourth Edition, December 1964.

12. ASTM Committee D-18: "Standard Test Method for Laboratory Determination of Water (Moisture) Content of Soil, Rock, and Soil-Aggregate Mixtures", from Annual Book of ASTM Standards, Section 4, Vol. 04.08,1991. 
13. ASTM Committee D-18: "Standard Test Method for Permeability of Granular Soils (Constant Head)", from Annual Book of ASTM Standards,section 4, Vol. 04.08, 1991.

14. Alsono, M., M. Satoh, and K. Miiynami: "Void-Size Distribution in TwoDimensional Random Packings of Equal-Sized Disks", The Canadian Journal of Chemical Engineering, Vol. 70, February 1992, pp. 28-32.

15. Ouchlyama, N.: "Porosity Estimation from Particle Size Distribution", Ind. Eng. Chem. Fundam., Vol. 25, No. 1, 1986, pp. 125-129.

16. Aberg, B.: "Hydraulic Conductivity of Noncohesive Soils", Journal of Geotechnical Engineering, Vol. 118, No. 9, September 1992, pp. 1335-1347.

17. Ameri, S., T.P. Meloy, and K. Aminian: "Permeable Rock Model Using an Array of Pores", Powder Technology, Vol. 75, 1993, pp. 107-112. 


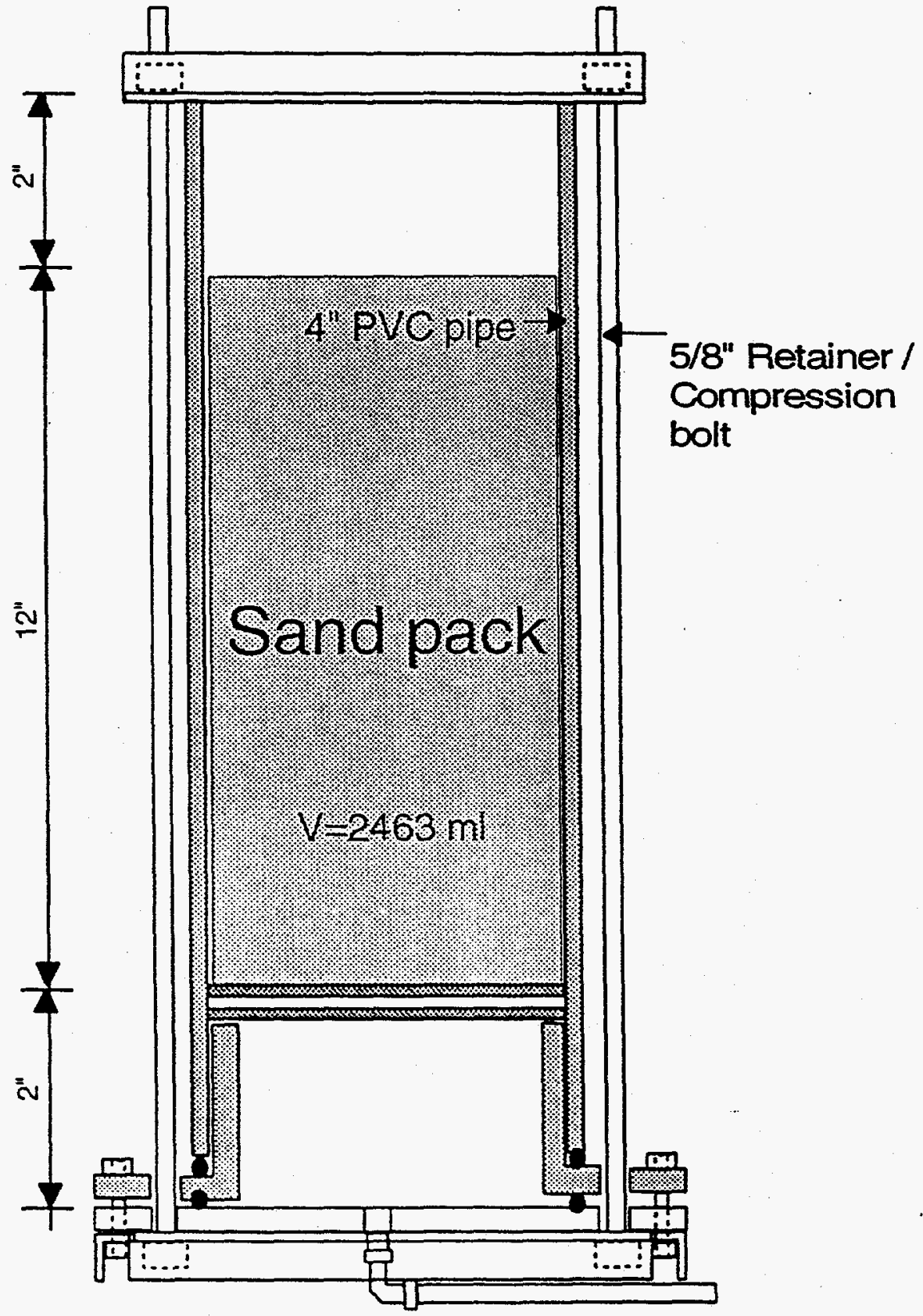

Figure 1: Sand-pack chamber for compaction. 


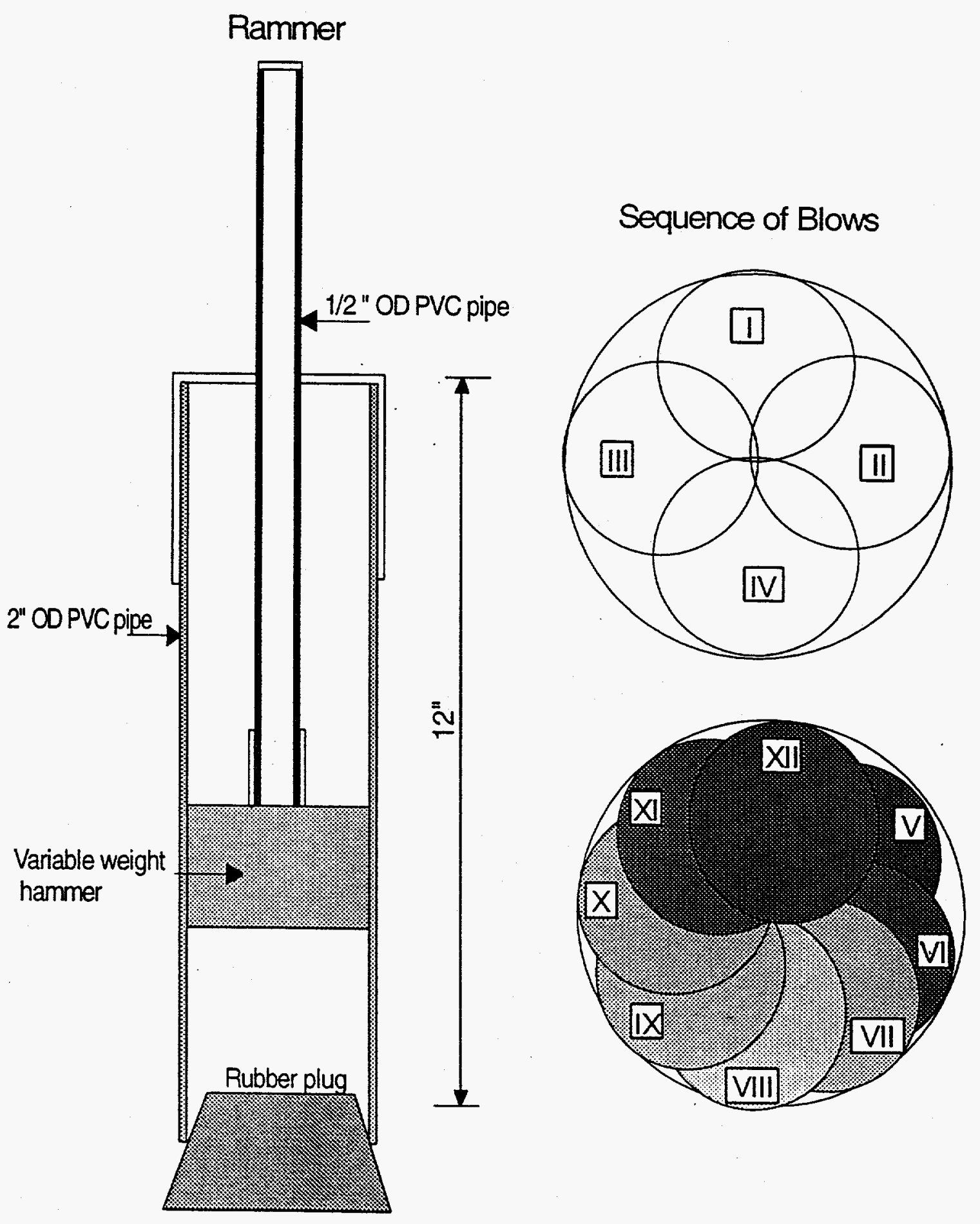

Figure 2: The rammer and sequence of blows for sand compaction. 


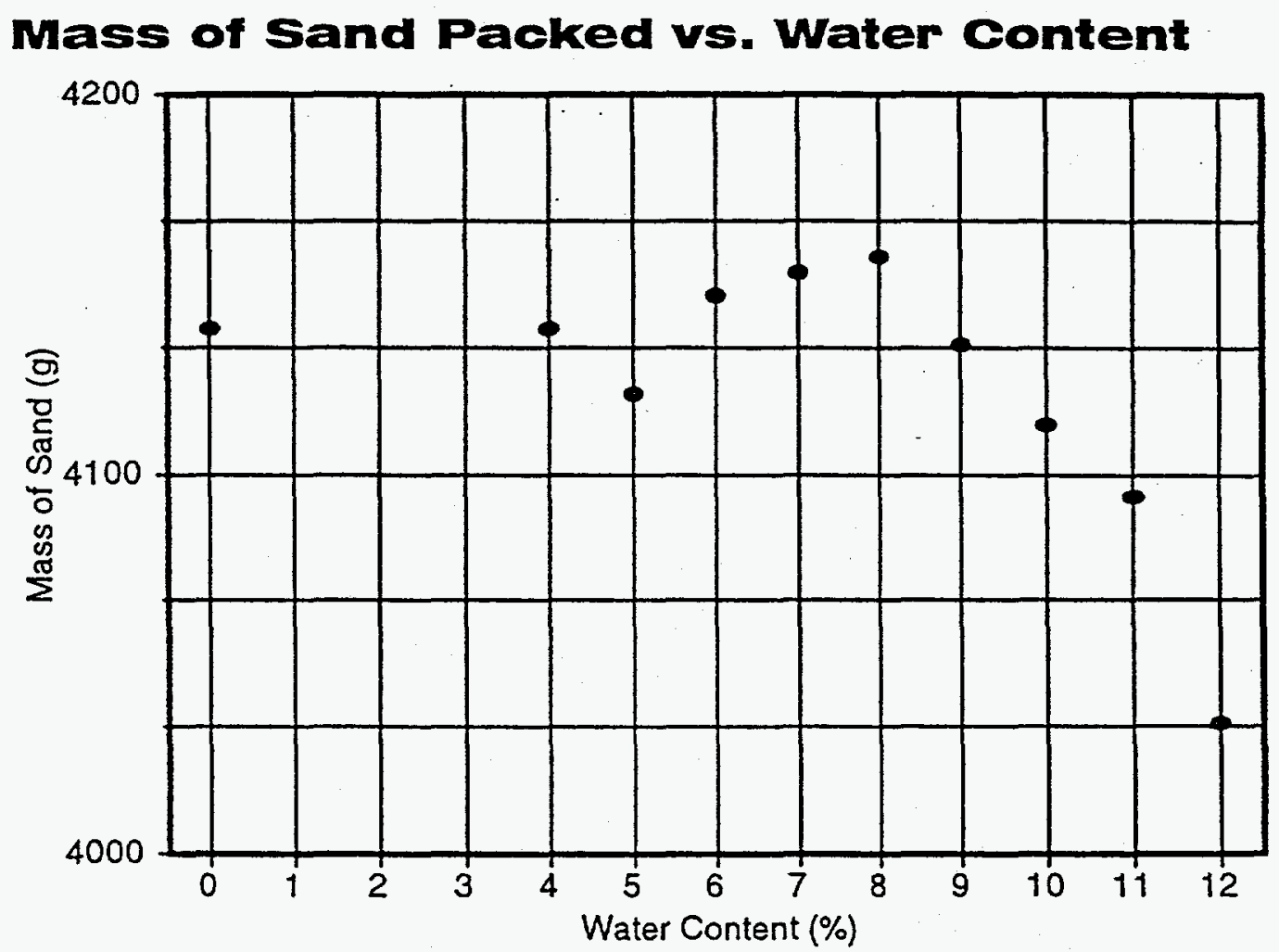

Figure 3: Optimum water content for sand compaction. 


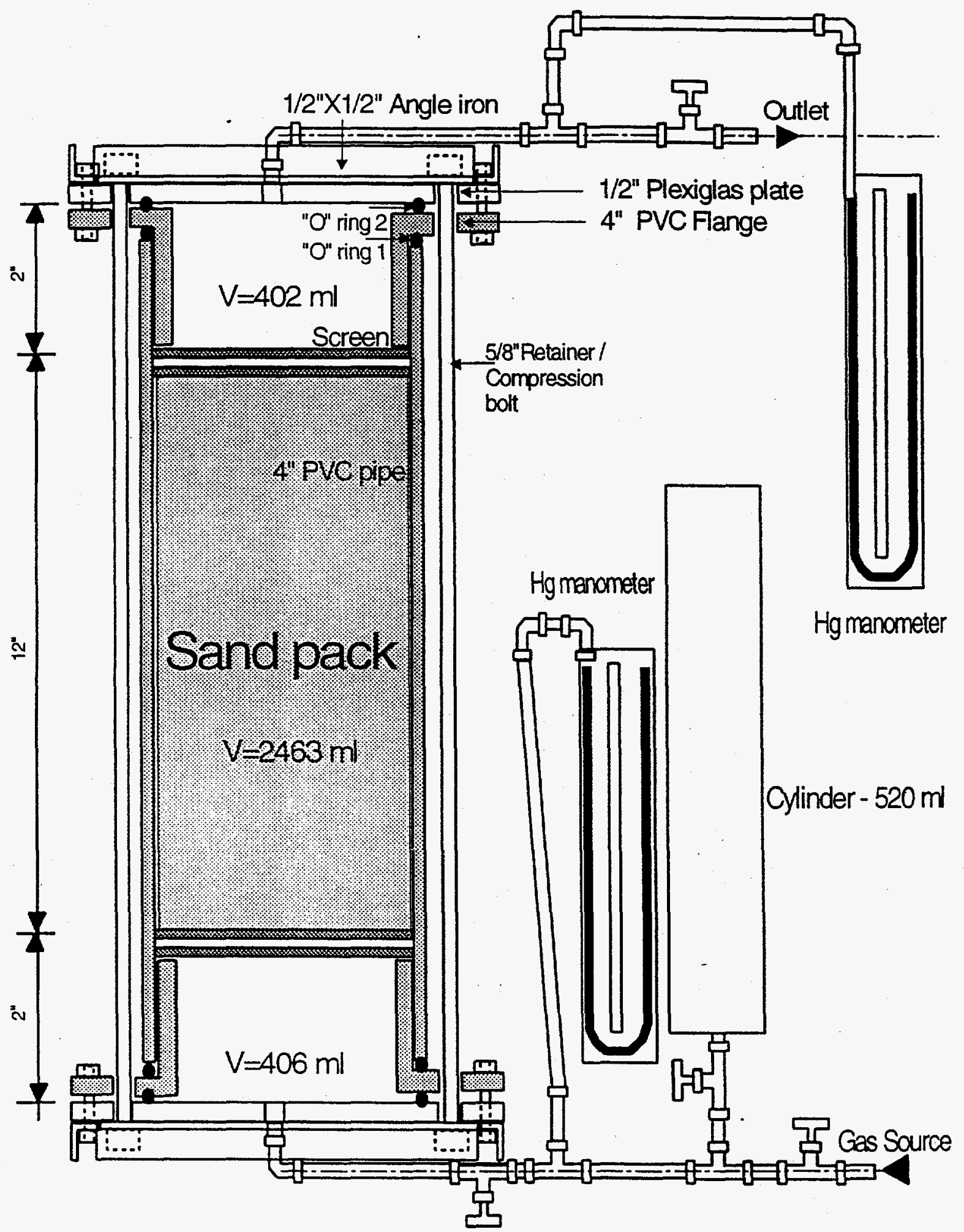

Figure 4: The experimental set up for porosity measurements. 


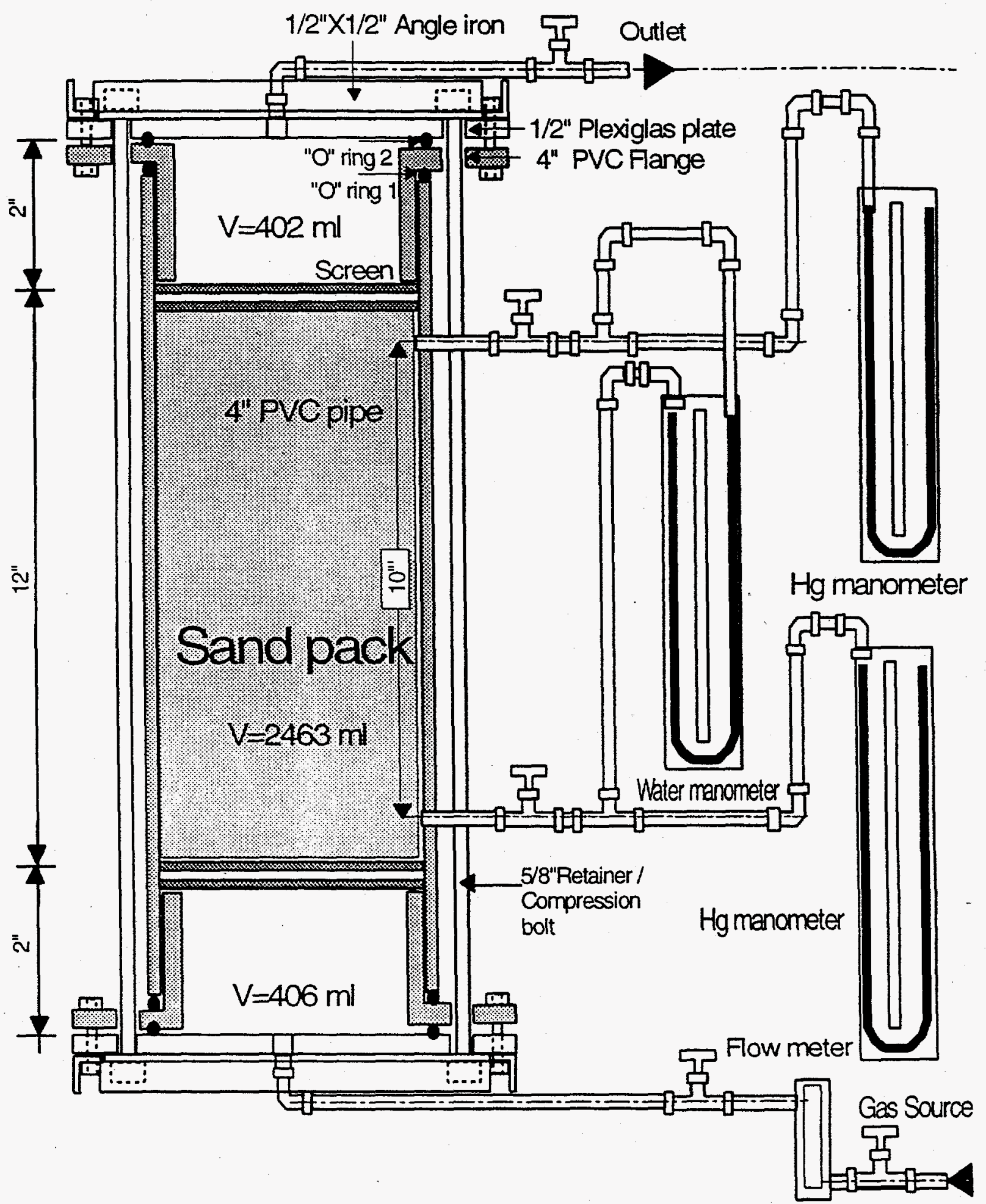

Figure 5: The experimental set up for permeability measurements. 


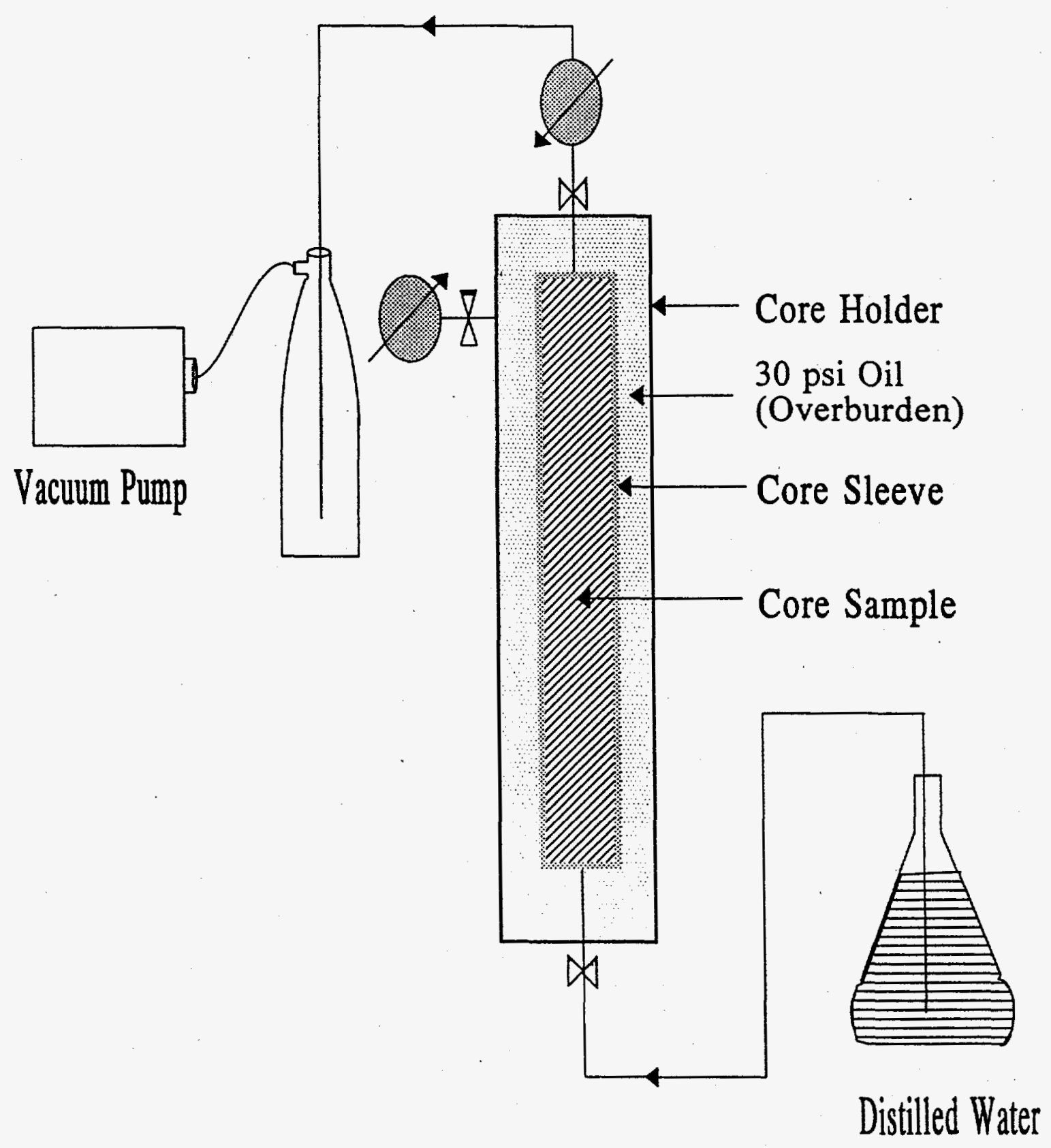

Figure 6: The experimental set up for core saturation. 
Humidity and

Temperature

Probe

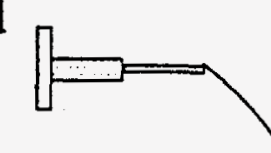

Moisture Trap

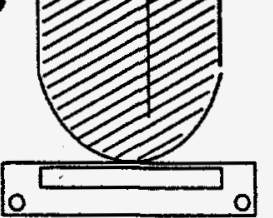

Digital Balance

Humidifier
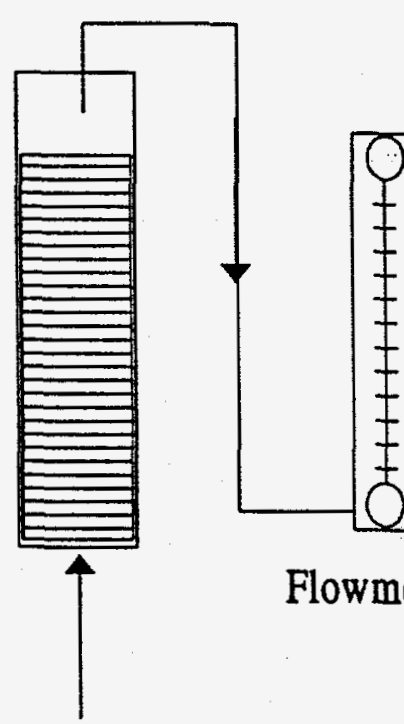

Flowmeter

Heat

Shrink

Sleeve

Mercury

manometer

Compressed Air

Figure 7: The experimental set up for core desaturation. 


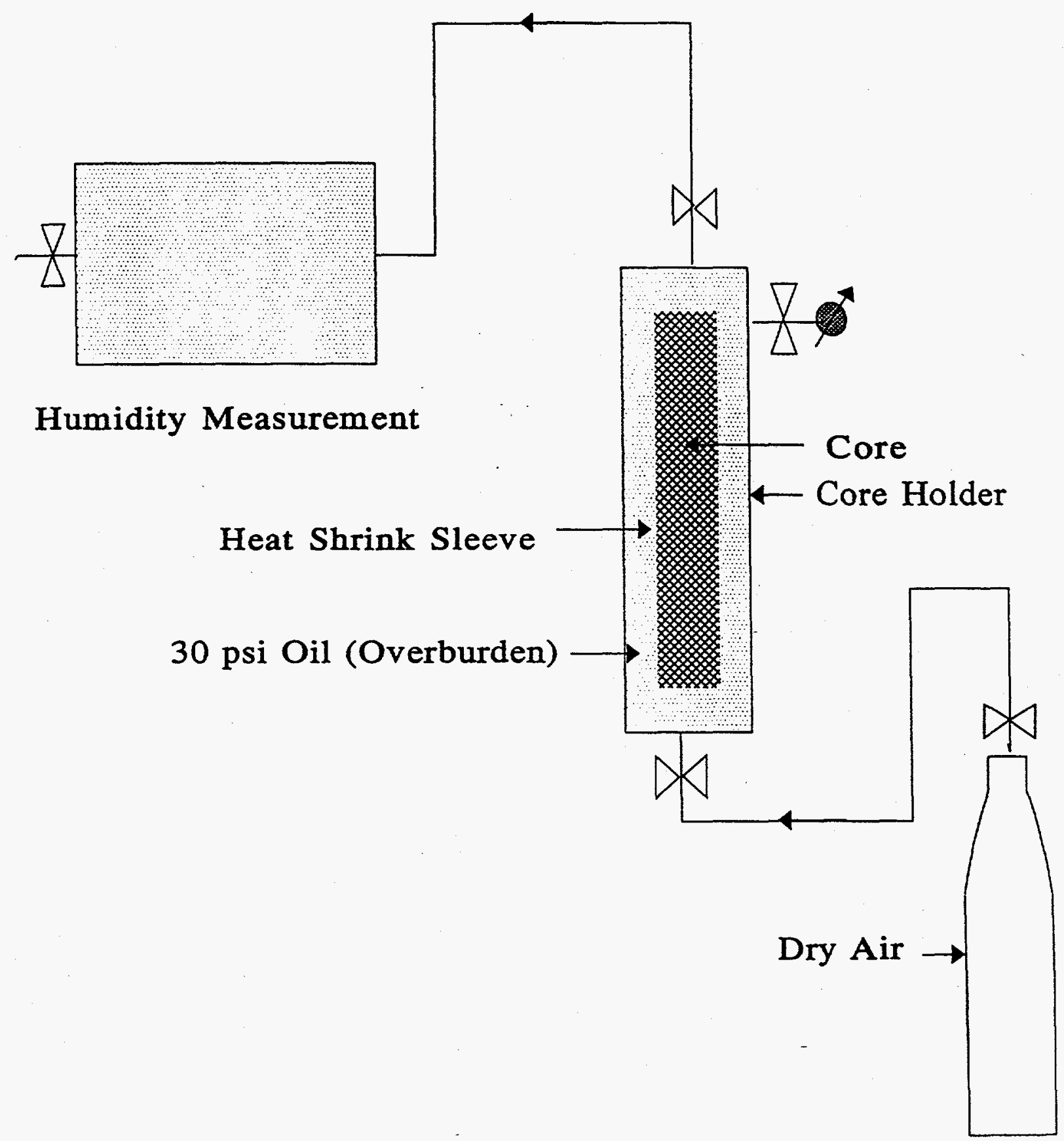

Figure 8: The experimental set up for air-water equilibrium in porous media. 


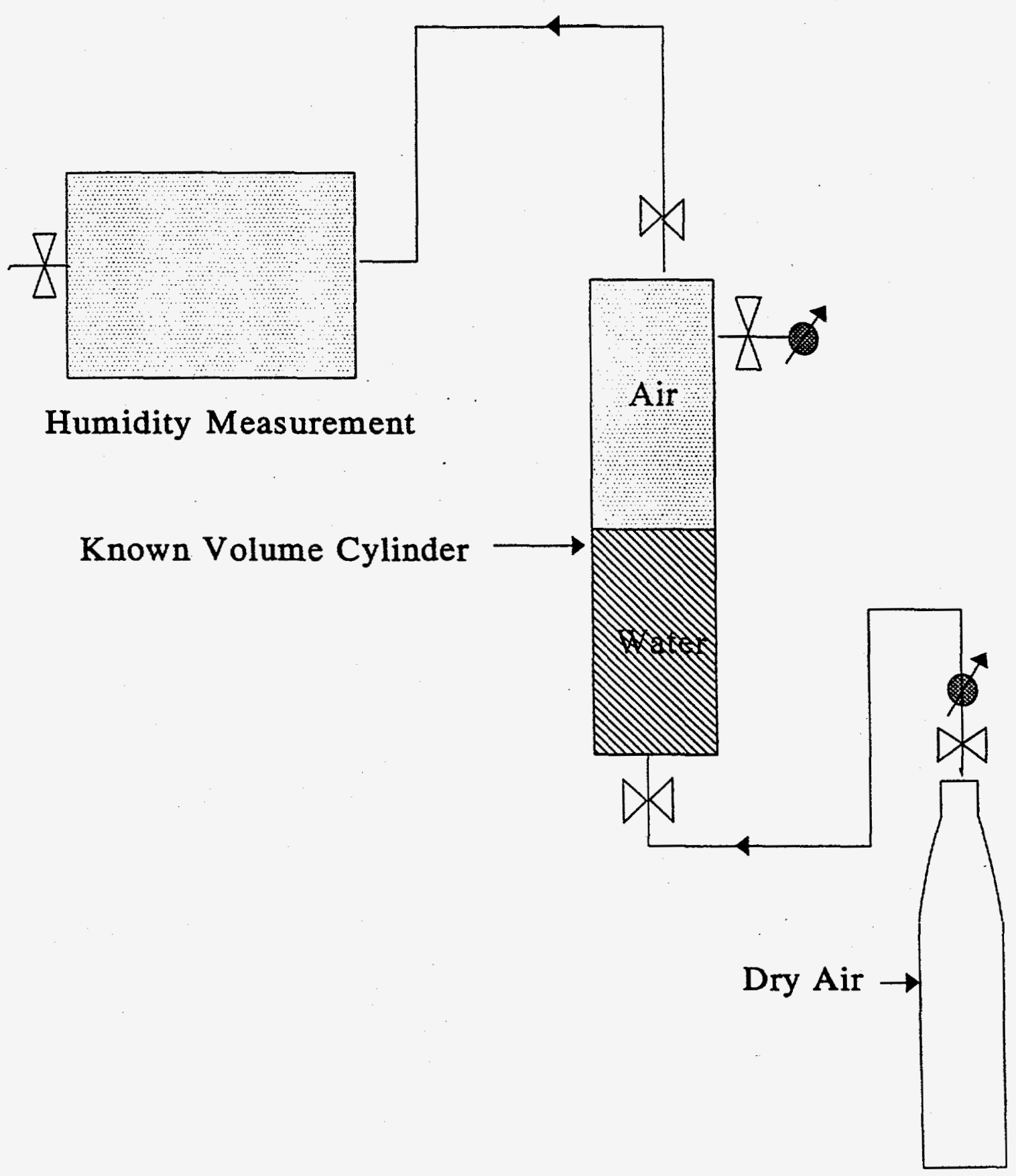

Figure 9: The experimental set up for air-water equilibrium. 
$-222-$ 


\section{0 \\ ADVANCED PRODUCT \\ APPLICATIONS TESTING}


$-224-$ 


\title{
Chemical Destruction of Chlorinated Organic Compounds
}

\author{
MC-6
}

\author{
METC TASK \# 2.1 \\ Quarterly Report for Period \\ January 1 through March 31, 1995
}

Work Performed Under Contract No.: $\quad$ DE-FC21-92MC29467

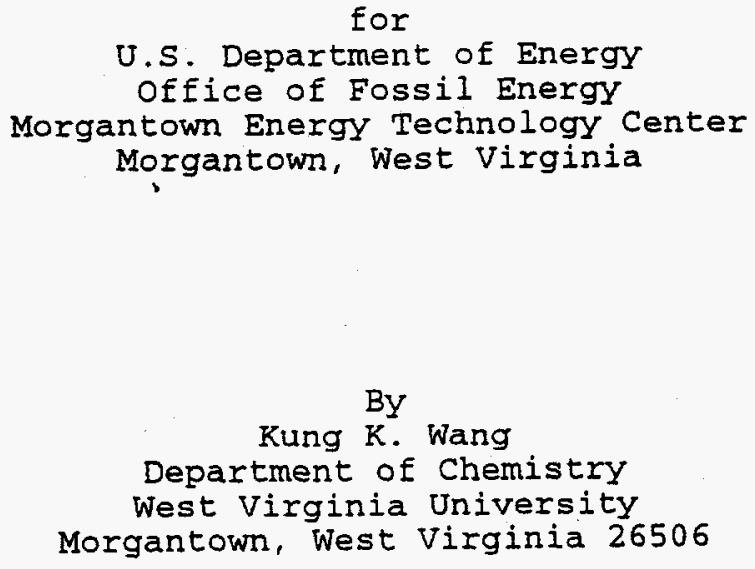

April 1995 
$-226-$ 
Chlorinated organic compounds, such as carbon tetrachloride, trichloroethylene, 2,4,5trichlorophenoxyacetic acid (2,4,5-T), and polychlorinated biphenyls (PCBs), have been widely used as organic solvents, pesticides and herbicides, dielectric fluids for transformers and capacitors, and for a variety of other purposes. The environmental problems and health risks associated with these chlorinated organic compounds have been well recognized. The chemical structures of some representative compounds are shown below.<smiles>O=C(O)COc1cc(Cl)c(Cl)cc1Cl</smiles>

It is the objective of this research program to develop chemical treatment procedures to transform chlorinated organic compounds to less or nontoxic materials. We discovered that sterically hindered triarylboranes are excellent electron carriers for sodium metal and can be used to effectively dechlorinate PCBs from greater than 500 PPM to less than 8 PPM, far less than the $50 \mathrm{ppm}$ standard set by EPA. Because PCBs are among the most inert chlorinated organic compounds, it is likely that this treatment procedure developed for PCBs could also be easily adopted for other chlorinated molecules, including particularly 2,3,7,8-TCDD because of similarity of chemical structures. We will develop a practical procedure to extend this treatment procedure further by synthesizing and fabricating new materials of triarylborane for use in dechlorination of a variety of chlorinated organic compounds. Other chemical treatment procedures for dechlorination of PCBs by using the very reactive hydroxyl radical and by nitration of PCBs to activate the aromatic ring for subsequent dechlorination will also be investigated. 
$-228-$ 
Section No.

Page No.

1.0 INTRODUCTION $\ldots \ldots \ldots \ldots \ldots \ldots \ldots \ldots \ldots \ldots \ldots \ldots \ldots$

$2.0 \quad$ PURPOSE $\quad \ldots \ldots \ldots \ldots \ldots \ldots \ldots \ldots \ldots \ldots \ldots \ldots \ldots \ldots \ldots \ldots \ldots$

$3.0 \quad$ BACKGROUND $\quad \ldots \ldots \ldots \ldots \ldots \ldots \ldots \ldots \ldots \ldots \ldots \ldots \ldots \ldots \ldots \ldots$

4.0 METHODOLOGY $\ldots \ldots \ldots \ldots \ldots \ldots \ldots \ldots \ldots \ldots \ldots \ldots \ldots \ldots \ldots \ldots \ldots$

5.0 WORK PERFORMED THIS PERIOD $\ldots \ldots \ldots \ldots \ldots \ldots \ldots$

6.0 RESULTS AND DISCUSSION $\quad \ldots \ldots \ldots \ldots \ldots \ldots \ldots$

7.0 CONCLUSIONS $\quad \ldots \ldots \ldots \ldots \ldots \ldots \ldots \ldots \ldots \ldots \ldots$

8.0 WORK PLANNED FOR NEXT PERIOD $\ldots \ldots \ldots \ldots \ldots \ldots \ldots$

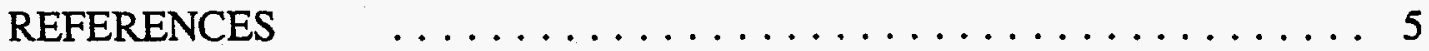




\section{LIST OF FIGURES}

Figure

Page No.

Figure 1. Chemical Structures of Three Representative

Polychlorinated Biphenyls $\ldots \ldots \ldots \ldots \ldots \ldots \ldots$

Figure 2 The Synthetic Sequence for Monomers 1 and 2 and Polymer 3

3

Figure 3 Synthesis of Compound 6 Having Two Triarylboryl Groups 


\section{EXECUTIVE SUMMARY}

We successfully developed a synthetic procedure for preparing a monomer containing a sterically hindered triarylboryl functionality. An attempt to produce the corresponding polymer as a potential electron carrier for dechlorination of PCBs by a palladium-catalyzed process was also performed. The resulting material is being characterized. A new compound containing two triarylboryl groups was also synthesized. 
$-232-$ 


\subsection{INTRODUCTION}

Polychlorinated biphenyls, commonly referred to as PCBs, are one of the major organic pollutants in the environment. The chemical structures of three representative polychlorinated biphenyls are shown in Figure 1. The large scale use of PCBs for a variety of purposes, especially as a dielectric material in capacitors and transformers as well as plasticizers and solvents in plastics and printing inks, coupled with the chemical stability of PCBs against degradation have resulted in their worldwide accumulation in the environment.

Figure 1. Chemical Structures of Three Representative Polychlorinated Biphenyls
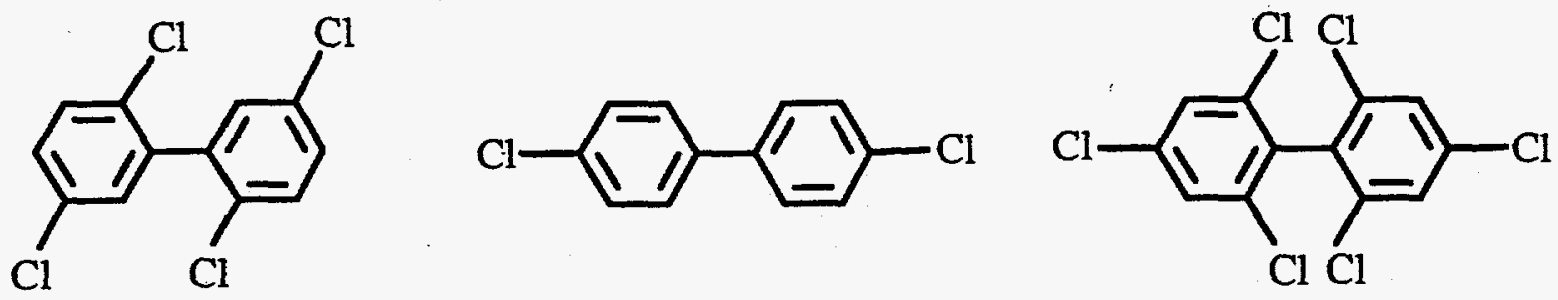

The total worldwide production of PCBs through 1980 is estimated to be approximately 2.4 billion pounds. Of the 1.25 billion pounds of PCBs estimated to have been produced in the United States; mainly by Monsanto under the registered trademark of Aroclor, about 24 million pounds are believed to have been released to the environment.

The toxic effects of PCBs have been well documented. One of the most famous cases occurred in Japan in 1968 when PCBs from a defective heat exchanger were leaked into rice oil which was then consumed by more than 1000 people. ${ }^{1}$ For those who consumed more than 0.5 grams (average consumption was, 2 grams), severe acne, darkened skin, and eye damage developed. Recovery was slow and these symptoms were still present even after three years. Numerous studies have also reported the toxic effort of PCBs to a wide range of wildlife, including mink, some species of shellfish, shrimp, and fish, and especially those birds that are at the top of the food chain, such as eagles, hawks, falcons, and pelicans. ${ }^{2}$ The chronic (longterm) toxicity to humans and other species is yet to be fully realized.

Because of the thermodynamic stability of PCBs, destruction by incineration and other chemical degradation processes are difficult. Disposal of untreated PCBs by landfill is virtually banned by the Resource Conservation and Recovery Act (RCRA). Currently, incineration is still the most widely used method for treating many hazardous wastes, including PCBs. Incinerators are strictly regulated to assure effective destruction of PCBs. For example, the regulation requires $99.9999 \%$ (six-9's) efficiency for the degradation of nonliquid PCBs by incineration. 
However, despite such strict regulations it is possible that trace amounts of PCBs as well as other combustion byproducts, including the much more toxic polychlorinated benzofurans and dioxins, could still be released to the environment through stack emission. Concerns about the health impact of PCBs, dioxins, and other organic compounds formed and emitted into the environment have on surrounding communities have created many controversies and strong opposition from various environmental groups. It is now typical to take more than ten years and prolonged legal battle before an incinerator for industrial hazardous wastes could be constructed and operated. One recent example involves the Waste Technologies Industries (WTI) facility in East Liverpool, Ohio which recently began its test burn only after 13 years of planning and construction, more then 20 court cases, and even the intervention of the Vice President of the United States. In an article of the Chemical and Engineering News, many issues concerning hazardous waste incineration were raised and discussed. ${ }^{3}$ It is clear that there is a need to continue research and development of alternative chemical processes for treating hazardous wastes in general and PCBs and other chlorinated aromatic compounds in particular.

\section{$2.0 \quad$ Purpose}

It is the purpose of this research project to first evaluate the existing technologies for in situ dechlorination of PCBs-contaminated soil. Development of a new chemical treatment procedure for dechlorination of PCBs will also be a major goal.

\subsection{Background}

Development of chemical process for the destruction of PCBs and other chlorinated aromatic compounds continues to be a research area of intense interest. Limited success has been achieved in some specific cases. We recently discovered that sterically hindered triarylboranes are excellent electron carriers for sodium metal and can be used to effectively dechlorinate PCBs from greater than 500 PPM to less than 8 PPM, far less than the $50 \mathrm{ppm}$ standard set by EPA. Because PCBs are among the most inert chlorinated organic compounds, it is likely that this treatment procedure developed for PCBs could also be easily adopted for other chlorinated molecules, including particularly 2,3,7,8-TCDD because of similarity of chemical structures. The use of the very reactive hydroxyl radical for dechlorination of PCBs was also found to be a promising process.

\subsection{Methodology}

We will develop a practical synthetic procedure to prepare and fabricate new materials containing triarylboranes as electron carriers for dechlorination of PCBs. Synthetic methods involving organic reactions will be employed to produce these new materials. The use of the very reactive hydroxyl radical, to be generated by the Fenton reaction $\left(\mathrm{FeSO}_{4} / \mathrm{H}_{2} \mathrm{O}_{2}\right)$ and other methods, for dechlorination of PCBs will also be investigated. Furthermore, an alternative strategy involving an initial activation of the benzene rings of $\mathrm{PCBs}$ by nitration $\left(\mathrm{HNO}_{3} / \mathrm{H}_{2} \mathrm{SO}_{4}\right)$ followed by attacking of the activated benzene rings with $\mathrm{NaOH}$ could also provide a solution for degradation of PCBs. 
We successfully developed a synthetic procedure for preparing a monomer containing a sterically hindered triarylboryl functionality. An attempt to produce the corresponding polymer as a potential electron carrier for dechlorination by a palladium-catalyzed process was also performed. The resulting material is being characterized. A new compound containing two triarylboryl groups was also synthesized.

\subsection{Results and Discussion}

We have successfully synthesized compounds 1 and 2 as precursors for polymer 3 containing sterically hindered triarylboryl functionality to be used as a potential electron carrier for dechlorination of PCBs (Figure 2). The structures of monomers 1 and 2 have been fully characterized by MS and ${ }^{1} \mathrm{H}$ NMR spectroscopy.

Figure 2. The Synthetic Sequence for Monomers 1 and 2 and Polymer 3
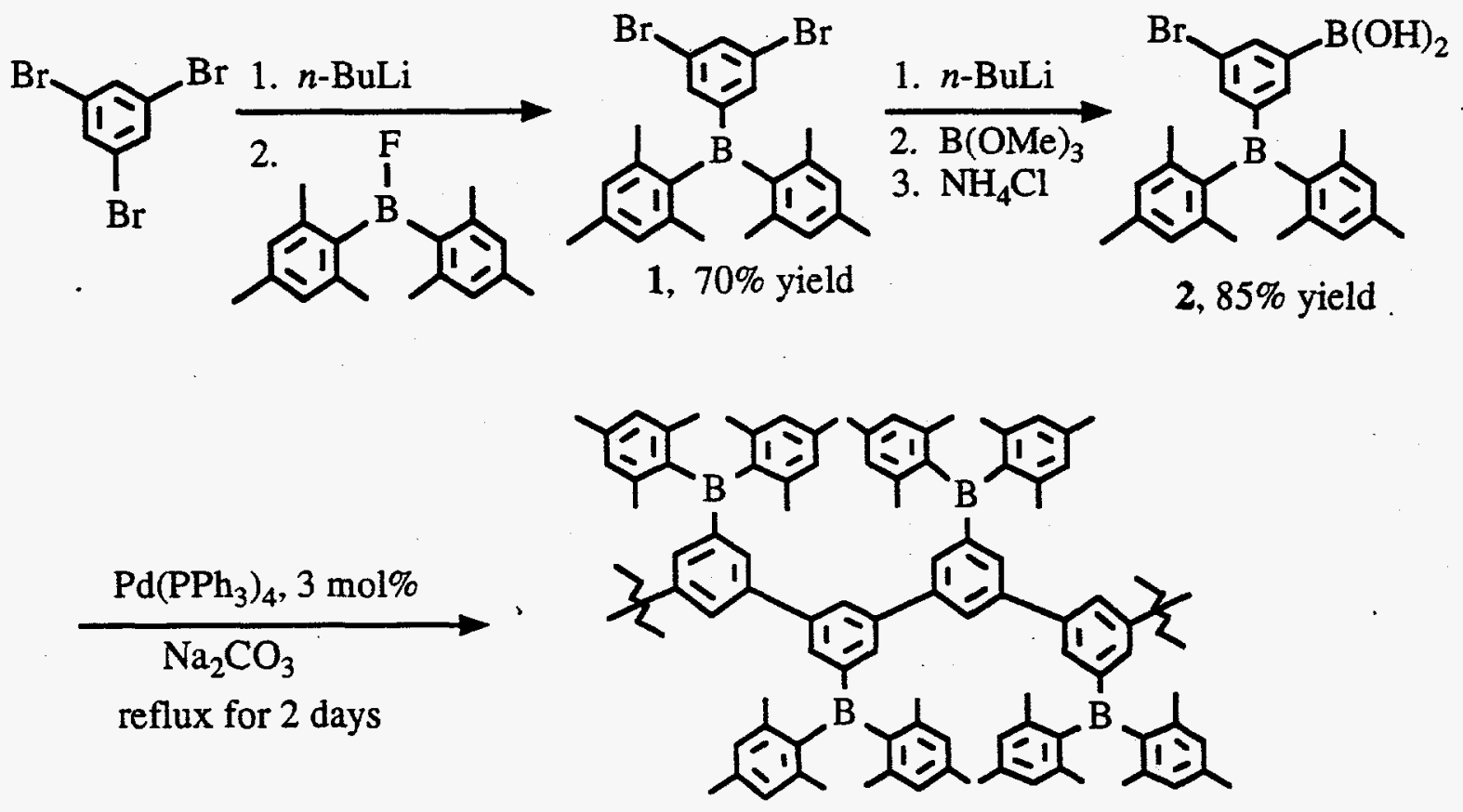

3

We have also conducted a palladium-catalyzed process in an attempt to promote polymerization of 2 to form 3 . While it appeared that a polymeric material was produced, the low solubility of this material in organic solvents made it very difficult to characterize. We are investigating the possibility of preparing lower molecular weight oligomers in order to facilitate structural elucidation. 
We have also successfully synthesized a new compound 6 containing two sterically hindered triarylboryl groups. The reaction sequence is summarized in Figure 3 . It is hoped that this new compound would exhibit a different electron-carrying ability and thus producing a different dechlorination property.

Figure 3. Synthesis of Compound 6 Having Two Triarylboryl Groups<smiles>CC(C)c1cc(C(C)C)c(B(c2ccccc2)c2ccccc2)c(C(C)C)c1</smiles>

4

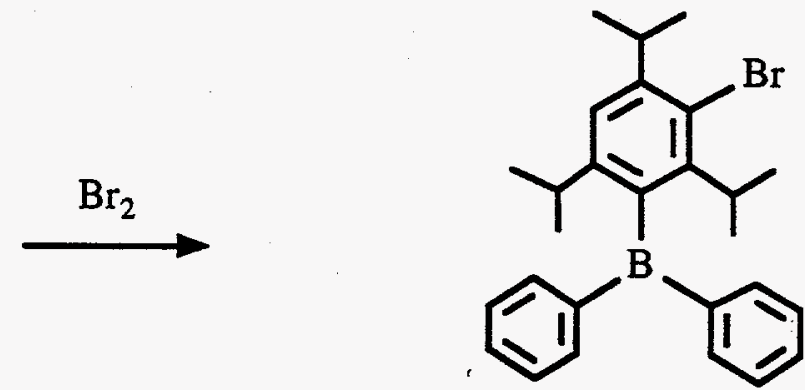

$5,73 \%$

1. $n$-BuLi

2. $\left(\mathrm{C}_{6} \mathrm{H}_{5}\right)_{2} \mathrm{BOC}_{2} \mathrm{H}_{5}$<smiles>CC(C)c1cc(C(C)C)c(B(c2ccccc2)c2ccccc2)c(B(c2ccccc2)c2ccccc2)c1B(c1ccccc1)c1ccccc1</smiles>

\subsection{Conclusions}

We now have successfully synthesized the requisite monomers for producing a polymeric material as an electron carrier for dechlorination of PCBs. While it appeared difficult to fully characterize the structure of the resulting polymeric material, new strategies are being employed to try to produce lower molecular weight oligomers to allow structural elucidation.

\subsection{Work Planned for Next Period}

We will contact commercial vendors to determine whether there are any practical technologies for in situ dechlorination of PCBs-contaminated soil. Furthermore, in addition to synthesizing a polymer containing sterically hindered triarylboranes, other chemical procedures including nitration of $\mathrm{PCBs}$ to activate the benzene rings followed by dechlorination with $\mathrm{NaOH}$ will be investigated. 


\section{References}

(1) Bailey, R.A.; Clarke, H.M.; Ferris, J.P.; Krause, S.; Strong, R.L., Chemistry and the Environment, Academic Press: New York, 1978; p 158.

(2) See reference $1 \mathrm{pp}$ 172-174.

(3) Hanson, D.J., Chemical and Engineering News 1993, 71, 7. 
$-238-$ 


\title{
CONTINUED DEVELOPMENT OF AN ATMOSPHERIC MONITORING MASS SPECTROMETRY SYSTEM
}

\author{
METC TASK \# 2.2
}

Quarterly Technical Progress Report

$$
1-1-95-3-31-95
$$

\section{Work Performed Under Contract}

No.: DE-FC21-92MC29467

For:

U.S. Department of Energy

Office of Fossil Energy

Morgantown Energy Technology Center

Morgantown, West Virginia

\author{
By: \\ F.L. King \\ Department of Chemistry \\ West Virginia University \\ Morgantown, WV 26506-6045
}


$-240-$ 


\section{ABSTRACT}

The objective of this project is the development of a mass spectrometric methodology applicable to the field determination of Volatile organic Compounds (VOC's), such as BTEX components (Benzene, Ioluene, Ethylbenzend, and Xylenes. A combination of chemical ionization, selective ion storage, and tandem mass spectrometry will be employed with an ion trap mass spectrometry system. The Gas Chromatography Mass Spectrometry (GC-MS) interface on the ion trap system will be modified to permit direct atmospheric monitoring. Through the use of tandem mass spectrometry methods the need for chromatographic separation will be eliminated reducing the overall size and complexity of the system. Existing literature methods and newly developed methods will be compared for sensitivity, accuracy, and precision. 
$-242-$ 


\section{TABLE OF CONTENTS}

Cover

Disclaimer

Abstract

Table of Contents

Executive Summary

Introduction

Purpose

Background

Methodology

Work Performed this Quarter

Results and Discussion

Conclusions

Work Planned for next Quarter

Technical/Administrative Matters 


\section{EXECUTIVE SUMMARY}

Although this project had a starting date of 1-1-95, funds were not made available to my department until 3-13-95. The work this quarter was limited to unfunded research conducted by undergraduate students. These students were brought into the project at the beginning of the Spring 1995 semester to permit preliminary development of tandem mass spectrometry (MS/MS) methods and to train these students in ion trap mass spectrometry. Currently an evaluation of the reproducibility of MS/MS results (energy resolved dissociation) is being conducted by the students. Results from this study will be contained in the next quarterly report. The hiring of personnel to work on the project for the remainder of its duration has begun. A small allotment of BTEX standard material was obtained with the assistance of the NRCCE at WVU. 


\subsection{Introduction}

In the general area of Characterization, Sensors, and Monitoring, analytical systems are needed that can provide near real-time measurements of hazardous materials and their degradation products at sites where contamination is suspected. Of particular interest are the volatile organic compounds (VOC'S) associated with petrochemicals. Presently, we are investigating the utility of atmospheric sampling mass spectrometry for the determination of benzene, toluene, ethylbenzene, and xylenes in ambient air. Preliminary methods relying on chemical ionization $(\mathrm{Cl})$ and/or tandem mass spectrometry (MS/MS) have been identified in a survey of the literature. It is proposed to continue this work by developing methods that employ a combination of $\mathrm{Cl}$ and MS/MS techniques with the ion trap mass spectrometer for the identification of components in mixtures. This expands upon the previous work by examining the influence of potential interferences on the accuracy of the methods and by developing appropriate protocols to eliminate these interferences or correct for them.

\subsection{Purpose}

The overall objective of this project is the development of an atmospheric monitoring ion trap mass spectrometry system and associated methods for determination of volatile organic compounds. One of our ultimate goals is to develop methods that can be employed by technician level operators. We believe that this is an essential first step toward the development of truly field portable mass spectrometry systems. Toward the end of the project we anticipate using the system at field sites to demonstrate the methods' capabilities. During the summer, at the Winnfield site in West Virginia the BTEX capabilities will be examined. This demonstration is planned to further our second goal, to gain the interest of a manufacturer in developing field portable MS systems. The manufacturer of the NRCCE trap, Varian, has expressed interest in the project. Prof. King has also been in contact with Finnigan MAT, the manufacturer of the original ion trap mass spectrometers. Finnigan MAT has agreed to loan Prof. King their newest generation ion trap for use during a three-year period beginning in late 1994. Our group will be in a unique position of having both traps available for a comparison of capabilities during the course of this project. We will keep both manufacuters informed regarding the results of our 
research.

During the 1995 project year specific goals are:

Develop and demonstrate a method for speciation of the components in a Gasoline Range Hydrocarbons standard containing aromatic and alkyl constituents.

Develop and demonstrate a method for the speciation of the components in a neutral chlorinated hydrocarbons standard containing aromatic and alkyl chlorinated hydrocarbons.

\subsection{Background}

During 1994, the NRCCE acquired an ion trap mass spectrometry system for use in atmospheric monitoring. Through funding of a project entitled "Evaluation of IR and Mass Spectrometric Techniques for On-Site Monitoring of Volatile Organic Compounds" mass spectrometric methods for separation and determination of the principal components in BTEX, (Benzene, Toluene, Ethlylbenzene, and Xylenes) were identified in the literature. The literature methods indicate some interference problems that must be considered to obtain accurate data, ie. the separation of xylenes and ethylbenzene. In the 1995 project year it is proposed to develop complete methods for the speciation of 10 components in an environmental petroleum standard and the speciation of 9 components in an environmental halogenated hydrocarbon standard. Our interest in the petroleum standard is to test the ability of the system to identify components in the atmosphere near a leaking petroleum tank; whereas, the interest in the halocarbons stems from a desire to develop monitoring for off gas from hazardous waste incinerators. During the course of the work potential interferences arising from both the sample and the monitoring environment will be identified. The original methods will then be modified by employing selective reagent chemical ionization and/or tandem mass spectrometry to selectively identify the species of interest and to eliminate the influence of the inteferent species. 


\subsection{Methodology}

A will be developed by modifying those found in the literature for use with triple quadrupole mass spectrometry systems. Water chemical ionization will be employed to provide strong, characteristic molecular ion signals for the analytes. Selective ion storage software is to be available from the manufacturer in early May 1995 . This software will facilitate the use of ion integration for calibration and any MS/MS methods. Any interferences will be identified, and MS/MS routines developed to eliminate the interference problem. The potential of using negative ion $\mathrm{Cl}$ will also be investigated for the halogenated hydrocarbons as well when an ion trap system with negative ion capabilities becomes available in the Fall of 1995.

\subsection{Work Performed This Quarter}

Work this quarter was limited to the training of unpaid undergraduates in the use of the ion trap mass spectrometer. These students have now begun evaluating reproducibility of MS/MS results with the ion trap mass spectrometer. Plans were made to hire these students to work on the project during the summer. This approach makes best use of the time spent training them in the use of the system. Two graduate students have also been hired to work through the summer on this project. A small amount of BTEX standard was obtained throught the WVU NRCCE.

\subsection{Results and Discussion}

During this initial quarter only training of personell and preliminary investigations have been conducted. The project remains on schedule because most of this quarter was set aside for such training and hiring of personnel. The evaluations of MS/MS performance for the ethylbenzenexylene separation have begun and will conclude in the next quarter.

\subsection{Conclusions}

As discussed above this was the induction period for the project, no conclusions are yet available. This progress is consistent with the propose timetable of tasks presented in the original proposal. 


\subsection{Work Planned for Second Quarter 1995}

With the beginning of paid researchers in May 1995, the project will pick up speed. We plan to evaluate the MS/MS methods in the lab during May and have the instrument at the Winnfield site in mid to late June to evaluate the performance of these methods in the field. The personnel dollars have been alloted heaviest during the early summer to facilitate the accomplishment of this goal by the end of June.

\subsection{Technical Administrative Matters}

Funding for this project arrived 13 March 1995. No personnel appointments are allowed by the University without available funds, therefore, the late arrival of funds precluded timely hiring of a postdoctoral research associate. It was decided to hire two graduate students, appointments begining May 15, to work on the project during the summer. Robert Steiner is a second year graduate student in the Ph.D. program with general expertise in ionization mechanisms and operational theory of mass spectrometry systems. Chris Lewis is a first year masters student whose thesis will focus on environmental applications of ion trap mass spectrometry. These students will be responsible for the development and evaluation of the atmospheric monitoring interface. During this semester work on the project consisted of efforts by unpaid undergraduate research assistants. These students worked with the ion trap mass spectrometer to gain with its operating principles and the application of tandem mass spectrometry procedures. Currently these students are conducting an evaluation of the reproducibility of tandem mass spectrometry results for toluene, xylene, and ethylbenzene. Initially these students were placed on the project to continue efforts until funded personnel became available. Because of their experience with the system, I plan to hire these students as research assistants during the summer of 1995. One of the students, Nate Sams, is graduating in May 1995 and will be hired for the duration of the project. Nate's excellence in analytical chemistry was recognized by receipt of the Society for Analytical Chemists of Pittsburgh College Chemistry Award. This team will be responsible for the development of analytical methods. The approach will be the use of selective ion storage to tune the ion trap to hold the chemical ionization reagent ions, $\mathrm{H}_{3} \mathrm{O}^{+}$, and selected parent molecules of BTEX components. Water chemical ionization 
has been shown to provide strong parent ion signals for aromatic species such as the BTEX components. The use of time-integrated signals for quantitation will be examined during the summer of 1995. 
$-250-$ 


\title{
Capture of Hazardous Waste Materials Utilizing Fluidization Coating Technology
}

\section{HZDWSTFLD}

\author{
METC TASK \# 2.3 \\ Quarterly Technical progress Report \\ Reporting Period: January 1 - March 31, 1995 \\ Work Performed Under Contract \\ No.: DE-FC21-92MC29467
}

\begin{abstract}
For:
U.S. Department of Energy

office of Fossil Energy

Morgantown Energy Technology Center

Morgantown, West Virginia
\end{abstract}

By:

Dr. Richard Turton

Department of Chemical Engineering

West Virginia University

Morgantown, WV 26506-6102

(i) 
$-252-$ 


\section{Abstract}

The purpose of this research is to investigate how fluidization coating technology can be utilized to capture and stabilize hazardous waste materials. In particular, the fate of aqueous solutions of heavy metal compounds will be addressed. These solutions will be sprayed into a high temperature fluidized bed containing different types of solids. Due to evaporation of the solution, the non-volatile inorganic materials will either concentrate on the fluidized particles or will form an aerosol of fine particles ( $<1$ micron) due to spray drying. The capture efficiency of the fluidized bed will be determined by evaluating the fraction of the heavy metals which is captured by the fluidized solids. The chemical form of the metals on the solids will also be determined and the leachability of the metals from the solids will be found. Techniques to further stabilize the metals on the fluidized particles will be addressed and may include a secondary spraying of stabilizing chemicals with an additional thermal treatment and over-spraying the fluidized particles with a low melting point glass. 
$-254-$ 
1.0 Introduction

2.0 Purpose

3.0 Background

4.0 Methodology

5.0 Worked Performed in this Period

6.0 Results and Discussion $\quad 7$

$\begin{array}{lll}7.0 & \text { Conclusions } & 7\end{array}$

8.0 Work Planned for Next Period 7

Appendix

References

Acronyms and Abbreviations

\section{List of Figures}

Figure 1: Sketch of Proposed Experimental Apparatus

\section{List of Tables}

Table 1: Tentative Work Schedule for Current Project 


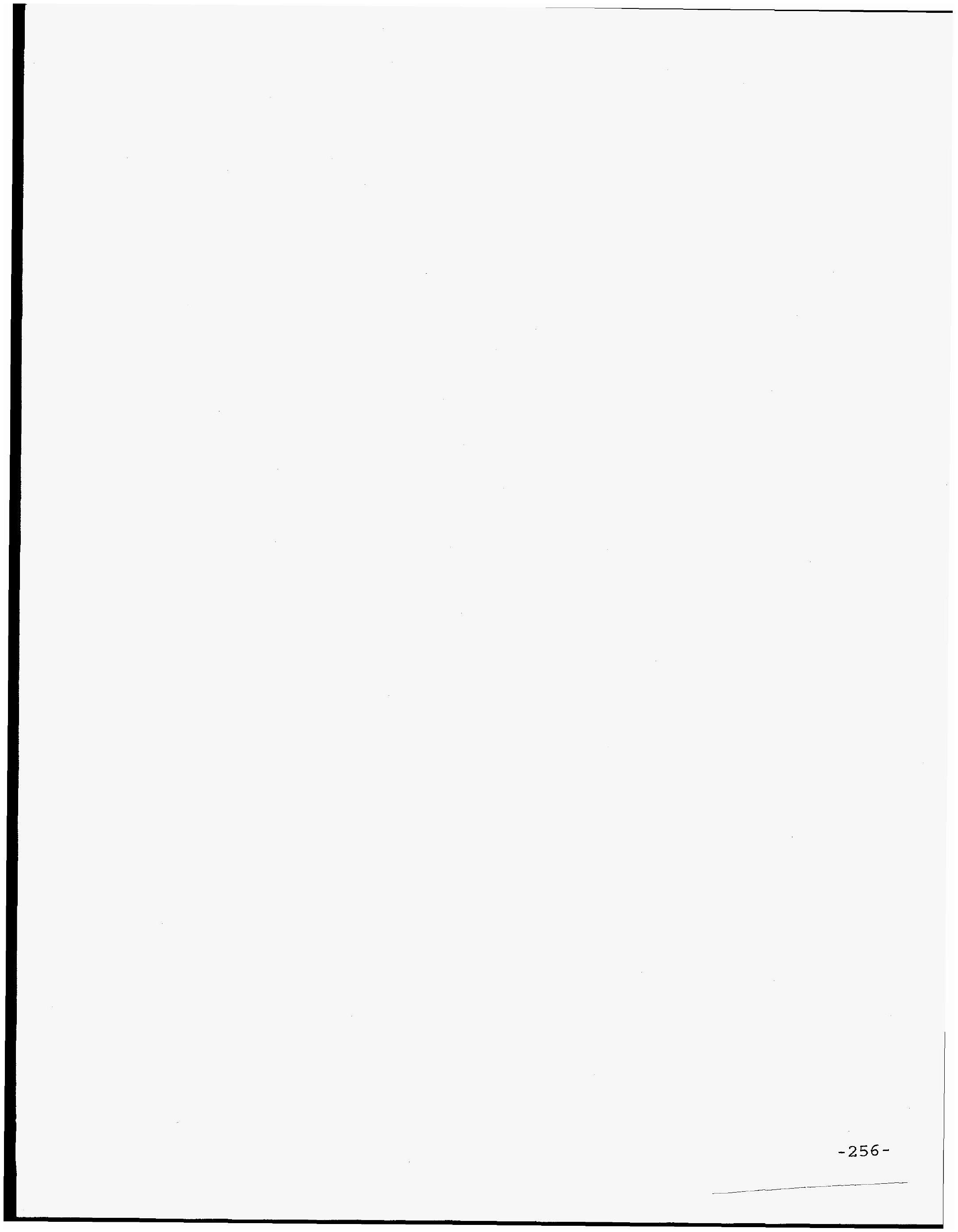

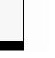




\section{Executive summary (Current Work)}

During the first period of this project, a model chemical solution was chosen for the coating experiments. This aqueous solution consists of the following heavy metal compounds:

$$
\begin{array}{ll}
\mathrm{Cr}\left(\mathrm{NO}_{3}\right)_{2} * 6 \mathrm{H}_{2} \mathrm{O} & 1 \% \text { by weight } \\
\mathrm{Ni}\left(\mathrm{NO}_{3}\right)_{2} * 6 \mathrm{H}_{2} \mathrm{O} & 1 \% \text { by weight } \\
\mathrm{Pb}\left(\mathrm{NO}_{3}\right)_{2} & 1 \% \text { by weight } \\
\mathrm{Cd}\left(\mathrm{NO}_{3}\right)_{2} * 4 \mathrm{H}_{2} \mathrm{O} & 1 \% \text { by weight }
\end{array}
$$

The metal compounds are consistent with the aqueous portions of several EPA recommended test wastes, for example, MWTP-5400, 3113/4 and 2110.

In addition, preliminary design of the fluidized bed coating system was completed. The fluidized bed will be manufactured from stainless steel pipe and will be inserted into a tube furnace to maintain the bed temperature. The aqueous solution will be fed to the bed via an atomizing nozzle located at the center of a perforated distributor plate. The atomizing and fluidizing gas will be nitrogen and the distributor plate will be designed so as to promote spouting. The exhaust gas from the bed will be filtered and cooled prior to discharging to the atmosphere. The choice of particle size and types of bed material to be used will be decided during the next period. 
$-258-$ 


\subsection{Introduction}

The capture and disposal of hazardous inorganic chemicals from liquid solutions and liquid-solid slurries currently is of great concern. Such hazardous chemicals typically contain heavy metal compounds, for example mercury, lead, cadmium, and sometimes radioactive species. The sources of these chemicals are diverse, and include: aqueous streams produced from washing contaminated soils; organic streams such as lead bearing paint; and dilute aqueous solutions of radioactive elements used in hospitals. The source and characteristics of the waste stream will often dictate the method of treatment. Methods such as adsorption on to activated carbon, incineration and gasification are all currently used to dispose of hazardous wastes containing heavy metals and radioactive species. The fate of the heavy metals and the their final chemical form is unclear, Barton et al. (1), for many treatment processes and this forms the raison d'etre for this research.

\subsection{Purpose}

The purpose of this research is to investigate the use of fluidized bed coating technology in the collection, concentration and stabilization of hazardous inorganic chemical compounds. Fluidization technology has been utilized in the destruction of waste streams in such applications as Municipal Solid Waste (MSW), Medical Waste and Hazardous Waste Incinerators. However, the emphasis has been on maximizing the destruction efficiency for organic compounds. Recently, with the increasing concern regarding the formation of dioxins and dibenzofurans in such devices, it has been suggested that gasification, rather than combustion, should be considered for the destruction of waste streams, Gallaway and Sprung (2). However, regardless of the method of destruction, if a waste liquid stream containing heavy/radioactive metals is to be fed to an incinerator/gasifier then the mechanism by which the inorganic material leaves the system needs to be investigated. Therefore, it is the purpose of this work to address what happens to such metal species when solutions of them are fed to fluidized bed waste incinerators/gasifiers.

\subsection{Background}

When considering the fate of liquid solutions of heavy metals fed to equipment containing fluidized solids, several removal mechanisms must be considered. It is assumed that the liquid stream will be sprayed into the bed via an atomizing or hydraulic spray nozzle. Clearly, it is important to disperse the liquid into the bed as a fine spray, in order to prevent excessive agglomeration and "wet quenching" of the bed. For waste incineration/gasification equipment typical bed temperatures will be high compared to the boiling point of the liquid and undesirable spray drying of the liquid waste may occur. The object when 
spraying the liquid feed into the fluid bed is to coat the fluidized particles with feed solution and to avoid spray drying. The efficiency of capture of the liquid is very important since liquid not deposited on particles will evaporate quickly in the vapor phase and effectively spray dry. When spray drying occurs the inorganic material, including any heavy metals, will tend to form a fine solid/aerosol mist that will be very difficult to clean from the gas stream. In fact, the formation of aerosols may so severely affect the efficiency of capture in such devices as scrubbers, bag houses and electrostatic precipitators that the majority of the metals end up in the stack gas. Therefore, the efficiency of spray capture by the fluidized particles is a very important factor in fluidized bed coating operations. For typical coating operations, the capture efficiency ranges from 95 - 99\%. However, typical coating operations do not use the level of superheat expected in combustion and gasification equipment.

The second consideration is the fate of the metals once they have been deposited on the solids surface and the liquid evaporated. Obviously, this will depend on the temperature and pressure (usually $1 \mathrm{~atm}$ ) in the bed, the chemical composition of the bed material and the gas phase composition. The gas phase composition will be mainly, nitrogen, water, carbon dioxide and oxygen with smaller amounts of hydrogen chloride, hydrogen sulfide (gasification) and sulfur dioxide (combustion). Evidence suggests that binding of the metals with the bed material is a strong function of the bed material, Ho et al. $(3,4)$ and that the leachability of metals from bed material is generally low.

Thus two key elements to be investigated are capture efficiency and stabilization of metals once they are on the bed material.

\subsection{Methodology}

The overall objectives of this work are to assess the potential of fluidized bed coating techniques to capture, concentrate and stabilize hazardous inorganic chemicals present in solution. The specific objectives are:

Identify model compounds to represent hazardous waste chemicals containing heavy metals.

Demonstrate that aqueous solutions of these model compounds may be sprayed onto a bed of fluidized particles resulting in the capture and concentration of these compounds on the particles.

Evaluate the capture efficiency of the fluidized bed coating process.

Investigate different routes to stabilize the model compounds so that the resulting bed particles have very low levels of leachable 
heavy metals and are hence non-hazardous.

With the above objectives in mind the specific tasks/deliverables for this project are given below:

Year 1

1. Design of a fluidized bed capable of operating at high temperatures (up to $900^{\circ} \mathrm{C}$ ) to be used in the coating experiments.

2. Construction of fluidized bed system.

3. Choice of a model chemical system for the hazardous waste and the size and materials to be used for the fluidized particles.

4. Production of samples of solid particles, impregnated with model compounds, produced via spraying solutions of these compounds into a fluidized bed.

5. Evaluation of the efficiency of capture of solutions of model compounds sprayed into the fluidized bed.

\section{Year 2}

6. Evaluation of the total heavy metal content and leachability of the heavy metals deposited on the fluidized particles and production of samples of such particles.

7. Evaluation of methods to stabilize heavy metals on fluidized particles. Variables to be considered are Temperature, Bed Material and addition of additional chemicals if required. stabilization will be determined by leachability tests on the solids. Production of samples of stabilized particles.

8. Evaluation of over-spraying fluidized bed particles with glass to stabilize heavy metals. This will be attempted if other methods of stabilization are unsuccessful. Production of samples of glass coated particles.

The work plan for this project is given in Table 1. 


\section{Table 1: Work Schedule}

\begin{tabular}{|c|c|c|c|c|c|c|c|c|c|c|c|c|c|c|}
\hline \multirow{3}{*}{ \# } & \multirow{3}{*}{ Task Name } & \multirow{3}{*}{ Dur } & \multirow{3}{*}{ \% Compl } & \multicolumn{11}{|c|}{1995} \\
\hline & & & & \multicolumn{3}{|c|}{ Q1 } & \multicolumn{3}{|c|}{ Q2 } & \multicolumn{3}{|c|}{$\overline{03}$} & \multicolumn{2}{|c|}{ Q4 } \\
\hline & & & & $\mathrm{J}$ & $F$ & $M$ & A & $M$ & $J$ & $J$ & $\mathbf{A}$ & $\mathbf{S}$ & O) $\mathbf{N}$ & $\mathrm{D}$ \\
\hline 1 & Design of Fluld Bed System & $4 M$ & $50 \%$ & & & & & & & & & & & \\
\hline 2 & Construction of Fuidl Bed & $4 M$ & $0 \%$ & & & $\square$ & 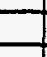 & & & ] & & & & \\
\hline 3 & Choose Model Chems \& Part & $2 M$ & $50 \%$ & & & * & _ & & & & & & & \\
\hline 4 & Production of Coated Solids & $4 M$ & $0 \%$ & & & & & & $\square$ & & & $\Rightarrow$ & & \\
\hline 5 & Evaluation of Coating Efficy. & $3 M$ & $0 \%$ & & & & & & L & & & E & & \\
\hline 6 & Report Preparation & $12 M$ & & & & & & & & & & & & \\
\hline 7 & Report 1 & $\mathbf{O M}$ & & & & 7 & & & & & & & & \\
\hline 8 & Report 2 & OM & & & & & & & $\infty$ & & & & & \\
\hline 9 & Report 3 & $\mathbf{O M}$ & & & & & & & & & & $\infty$ & & \\
\hline 10 & Annual Report - Year 1 & OM & & & & & & t. & & & & & - & $\infty$ \\
\hline 11 & Overall Work Completed & $12 M$ & & & & & & & & & & & & 7 \\
\hline
\end{tabular}




\subsection{Worked Performed in this period}

The start of the experimental portion of this project was delayed until March 8, 1995 due to funds not being available until this time. During the period $1 / 1 / 95-3 / 31 / 95$, for which this report is written, the following work was accomplished:

Item 1: The model compounds to be used for this study have been chosen to be an aqueous solution with the following composition:

$$
\begin{array}{ll}
\mathrm{Cr}\left(\mathrm{NO}_{3}\right)_{2} \star 6 \mathrm{H}_{2} \mathrm{O} & 1 \% \text { by weight } \\
\mathrm{Ni}\left(\mathrm{NO}_{3}\right)_{2} \mathrm{H}_{2} \mathrm{O} & 1 \% \text { by weight } \\
\mathrm{Pb}\left(\mathrm{NO}_{3}\right)_{2} & 1 \% \text { by weight } \\
\mathrm{Cd}\left(\mathrm{NO}_{3}\right)_{2} \star 4 \mathrm{H}_{2} \mathrm{O} & 1 \% \text { by weight }
\end{array}
$$

This aqueous solution is consistent with the concentration of RCRA metals that are present in the aqueous portion of the following EPA recommended test wastes - MWTP-5400: Heterogeneous Debris, MWTP3113/3114: Absorbed Aqueous and Organic Liquids, and MWTP-2110: Aqueous Halogenated Organic Liquids.

Item 2: Preliminary work has been done on the design of the fluidized bed system to be used in the coating experiments. A tentative sketch of the equipment showing pertinent details is shown in Figure 1. Referring to Figure 1, the aqueous solution containing the RCRA metals (item 1) will be gravity fed from a holding tank to the nozzle located at the center of the gas distributor plate. The liquid will be atomized using pressurized nitrogen in the nozzle. The temperature of the fluidized bed (stainless steel construction approx. $75 \mathrm{~mm}$ diameter) will be maintained by inserting the bed into a 3 zone pipe furnace. The central and end heaters will be controlled to give a close to constant bed temperature. The bed particles will be fluidized by the atomizing nitrogen/water mixture and by a separate nitrogen feed to the plenum of the bed. The gas distributor will be designed to promote spouting in the center of the bed by passing the majority of the fluidizing gas through the center of the plate, as shown in detail in Figure 1. The exhaust gases leaving the bed will pass upward through an expansion section to promote particlegas disengagement. The gas leaving the top of the expander section will first pass through a fine $(0.5 \mathrm{micron})$ filter to remove any metal aerosol particles formed by the spray drying of the liquid solution. The gas will then flow through a cold trap to condense the majority of the water and finally will be exhausted through a fume hood to the atmosphere. Metal capture efficiency will thus be determined by analysis of the metal content of: the particles; the water collected in the trap; and any particulate matter collected on the filter. A metal balance will be attempted by comparing the above measurements with the total amount of liquid sprayed into the bed during the coating experiment. 


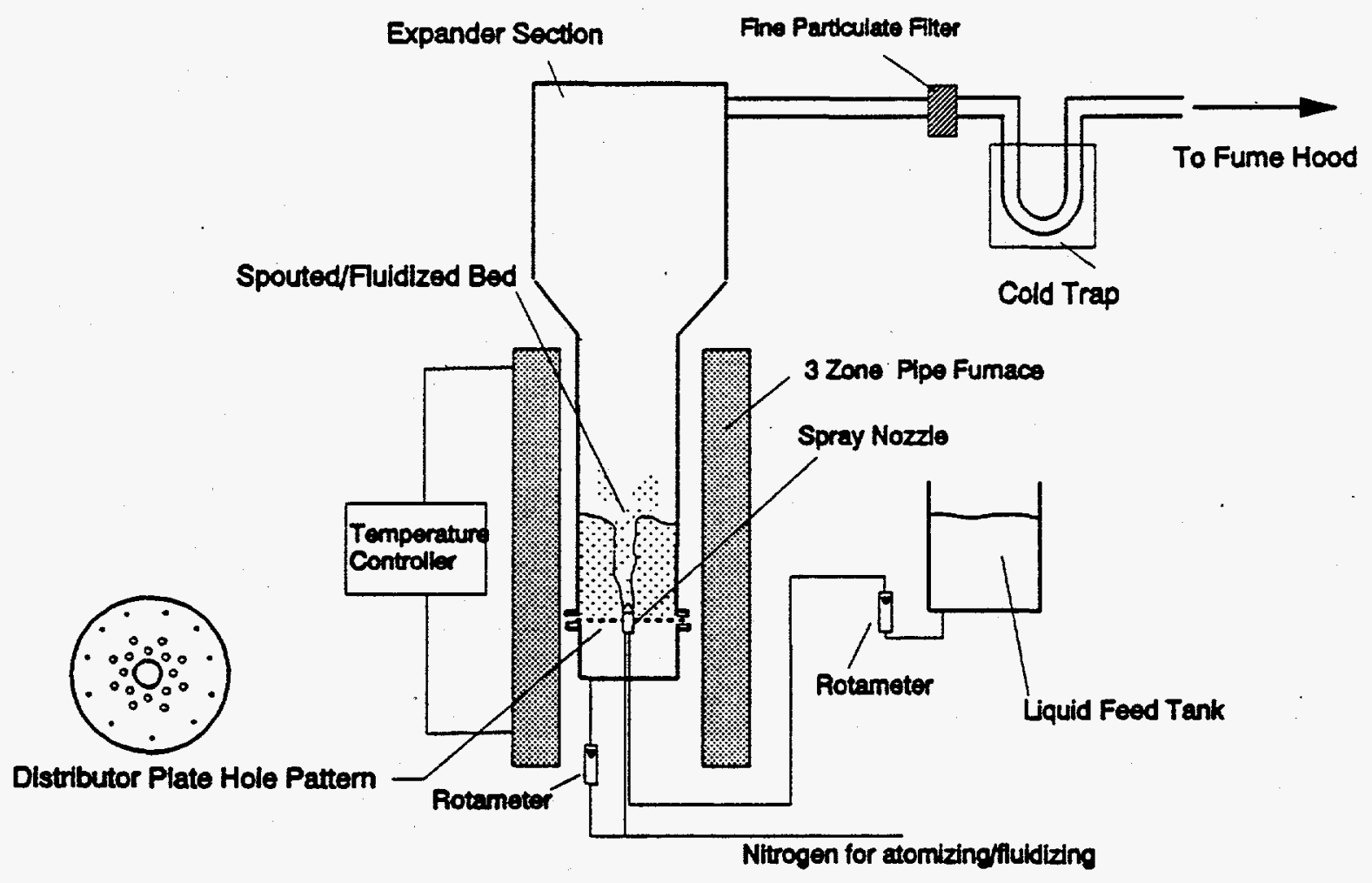

Figure 1: Sketch of Proposed Experimental Apparatus 


\title{
6.0 Results and Discussion (Current Period)
}

Due to the delay in project funding there are no experimental results to report at this time.

\subsection{Conclusions (Current Period)}

Due to the delay in project funding there are no conclusions to report at this time.

\subsection{Work Planned for Next Period}

The final design and commencement of construction of the fluidized bed is planned for the next (2nd) quarter. The tube furnace to be used in this work will be specified and ordered. In addition, the chemicals given in item 1 of section 5 of this report will be ordered and MSDS sheets will be obtained and displayed in room B65, Engineering Sciences Building, where these chemicals will be stored.

Consideration of the type of bed material will also be made and suitable suppliers will be identified.

\section{References}

1. R.G.Barton, W.D. Clark and W.R.Seeker, "Fate of metals in waste combustion systems", Comb. Sci. Tech., 74:327 (1990)

2. T.R.Gallaway and J.L.Sprung, "Destruction of UST Organics and Nitrates, Polymeric Organic Wastes, and Chlorocarbon Solvents by Steam Reforming", Proc. Waste Retrieval, Treatment and Processing Meeting, Houston, TX, 215-221, March (1993)

3. T.C. Ho, H.W.Chu and J.R.Hopper, "Metal volatilization and separation during incineration", Waste Mgment., 13,455-466 (1993)

4. T.C.HO, C.Chen, J.R.Hopper and D.A.Oberacker, "Metal capture during fluidized bed incineration of Wastes contaminated with lead chloride", Combustion Sci. Technol., 85, 101-116 (1992)

\section{Acronyms and Abbreviations}

\author{
MSDS - Material and Safety Data Sheets \\ MSW - Municipal Solid Waste \\ RCRA - Resource Conservation and Recovery Act (1976)
}


$-266-$ 


\title{
REMEDIATION OF HAZARDOUS SITES WITH STEAM REFORMING
}

Quarterly Report for Period

January 2, 1995 through March 26, 1995

(January - March 1995)

Work Performed Under Contract

No.: DE-FC21-92MC29467

(MTCI No. 10070)

\author{
For \\ U.S. Department of Energy \\ Office of Fossil Energy \\ Morgantown Energy Technology Center \\ Morgantown, West Virginia
}

\author{
By \\ Babak AghaMohammadi \\ Manufacturing and Technology Conversion \\ International, Inc. (MTCI) \\ Columbia, Maryland 21044
}

April 20, 1995 
$-268-$ 
Subsystem procurement, installation and checkout is proceeding. The evaporative heat exchanger was received and the steam superheater was designed and is being fabricated. 
$-270-$ 


\section{TABLE OF CONTENTS}

Section No.

Page No.

1. TECHNICAL BACKGROUND ................ 1

2. EXPERIMENTAL METHODOLOGY $\ldots \ldots \ldots \ldots \ldots \ldots$

3. EXPERIMENTAL RESULTS AND DISCUSSIONS $\ldots \ldots \ldots \ldots \ldots .3$

4. CONCLUSIONS $\ldots \ldots \ldots \ldots \ldots \ldots \ldots \ldots \ldots \ldots \ldots \ldots \ldots$ 


\section{LIST OF FIGURES}

Figure

Page No.

Figure 1. Process Flow Diagram $\ldots \ldots \ldots \ldots \ldots$

Figure 2. Air-Cooled Evaporative Heat Exchanger . . . . . . . . . . . 6

Figure 3. Schematic of Steam Superheater . . . . . . . . . . . . . 7 


\section{TECHNICAL BACKGROUND}

A complete discussion of the technical background was presented in the quarterly report for the period July 1, 1993 through September 30, 1993. For continuity of the discussion in this part, the following summary paragraph has been included herein.

The MTCI thermochemical reactor system has easily demonstrated at commercial levels its superior performance in the steam reforming of a wide variety of biomass, industrial and municipal waste feedstocks containing chlororganics as well as coal, coal liquefaction bottoms, and mild gasification char at ambient (atmospheric) conditions. The system processed a wide spectrum of feedstocks producing a hydrogen-rich product gas that is free of the diluents (primarily $\mathrm{N}_{2}$ ) found in air-blown steam reforming systems and is more cost-effective than oxygen-blown systems. In addition, liquid and solid waste streams from the MTCI system show extremely low levels of toxics and leachability, permitting easier landfill or industrial toxic byproduct recovery. The feasibility of developing a pressurized system based on the MTCI technology would permit even greater gains in processing yields, system modularity, and capital and operating costs for processing hazardous and other waste. This would especially be applicable to the cleanup and treatment of large volumes of soils contaminated with toxic organics, i.e., PCBs, pesticides, cyanides, RCRA metals, and dioxin/furans. Reformation of toxic organics in the oxidizing environment of incinerators are completely eliminated because of the reducing environment present in the MTCI thermochemical reactor (steam reformer). 


\section{EXPERIMENTAL METHODOLOGY}

The test plan and methodology remain the same as previously reported. 


\section{EXPERIMENTAL RESULTS AND DISCUSSIONS}

During this reporting period, the second-stage scrubber (C-6) and its circulation tank (C-7) (Figure 1 ) were received.

The air-cooled evaporative heat exchanger (Figure 2), purchased from Baltimore Air Coil, was also received.

The pulse combustor tube bundle is under fabrication and will be ready for refractory pouring by the end of April 1995.

The natural gas and air flow meters for the pulse combustor have been purchased and received.

The steam superheater has been designed. Figure 3 shows the schematic of this unit. It consists of a 30-inch carbon steel pipe with 3/8-inch wall thickness. The unit is 10 feet long and one end is caped. The saturated steam enters the unit at one end inside $10 \times 3 / 4$ " stainless steel tubing. Each tube is 20 feet long and U-shaped. The steam superheater has a 5-inch refractory lining. The fabrication of the unit is completed and it ready for refractory pouring. 


\section{CONCLUSIONS}

With procurement and receipts of materials and parts proceeding normally, it is anticipated that the pressurized system will be assembled and ready for checkout and shakedown by the end of August 1995.

\section{PLANS FOR NEXT REPORTING PERIOD}

- Pour pulse combustor refractory.

- Pour steam superheater refractory.

- Begin erecting the subsystems. 


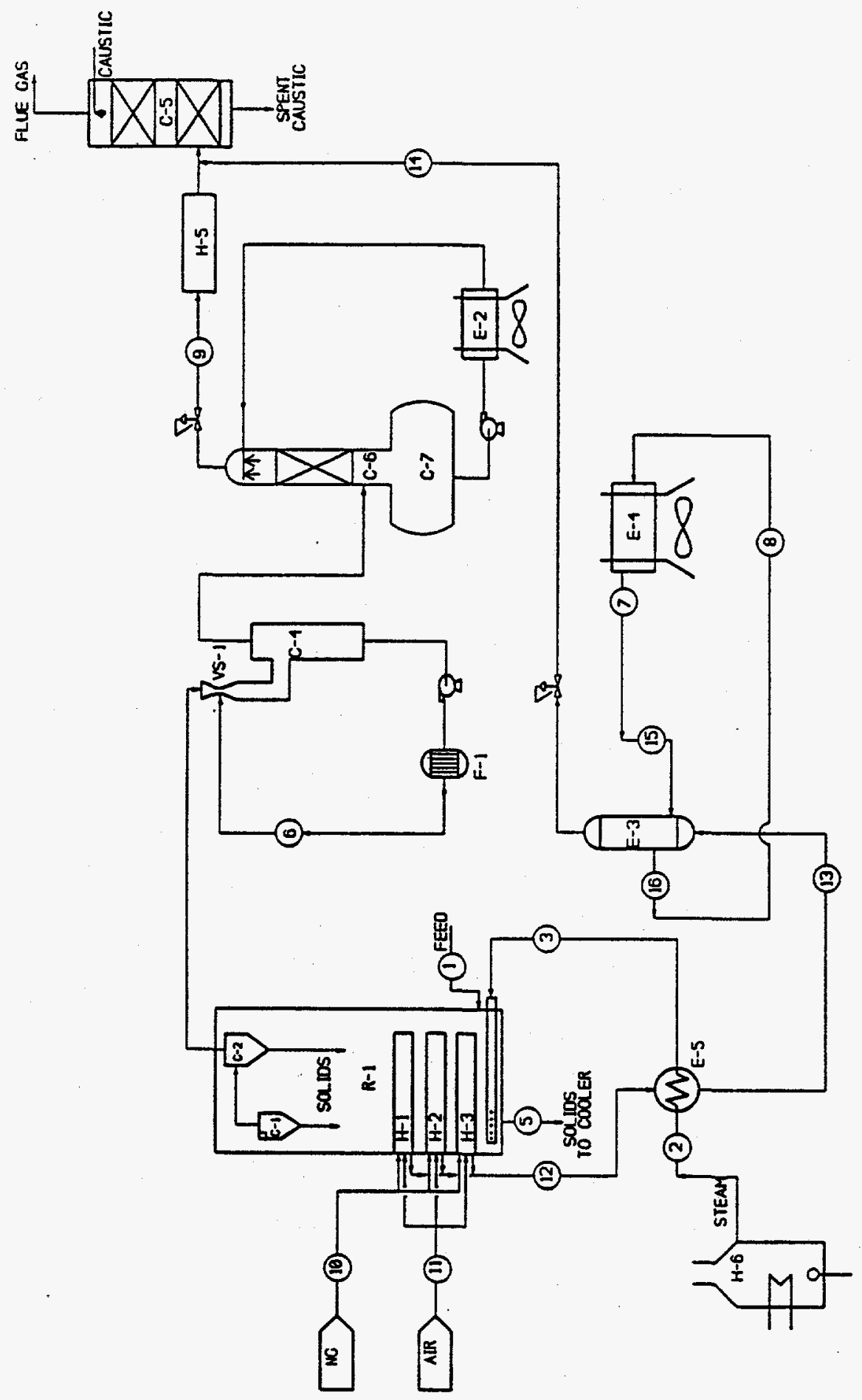

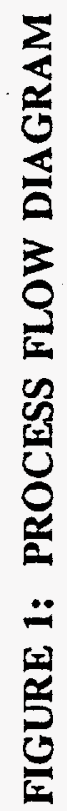




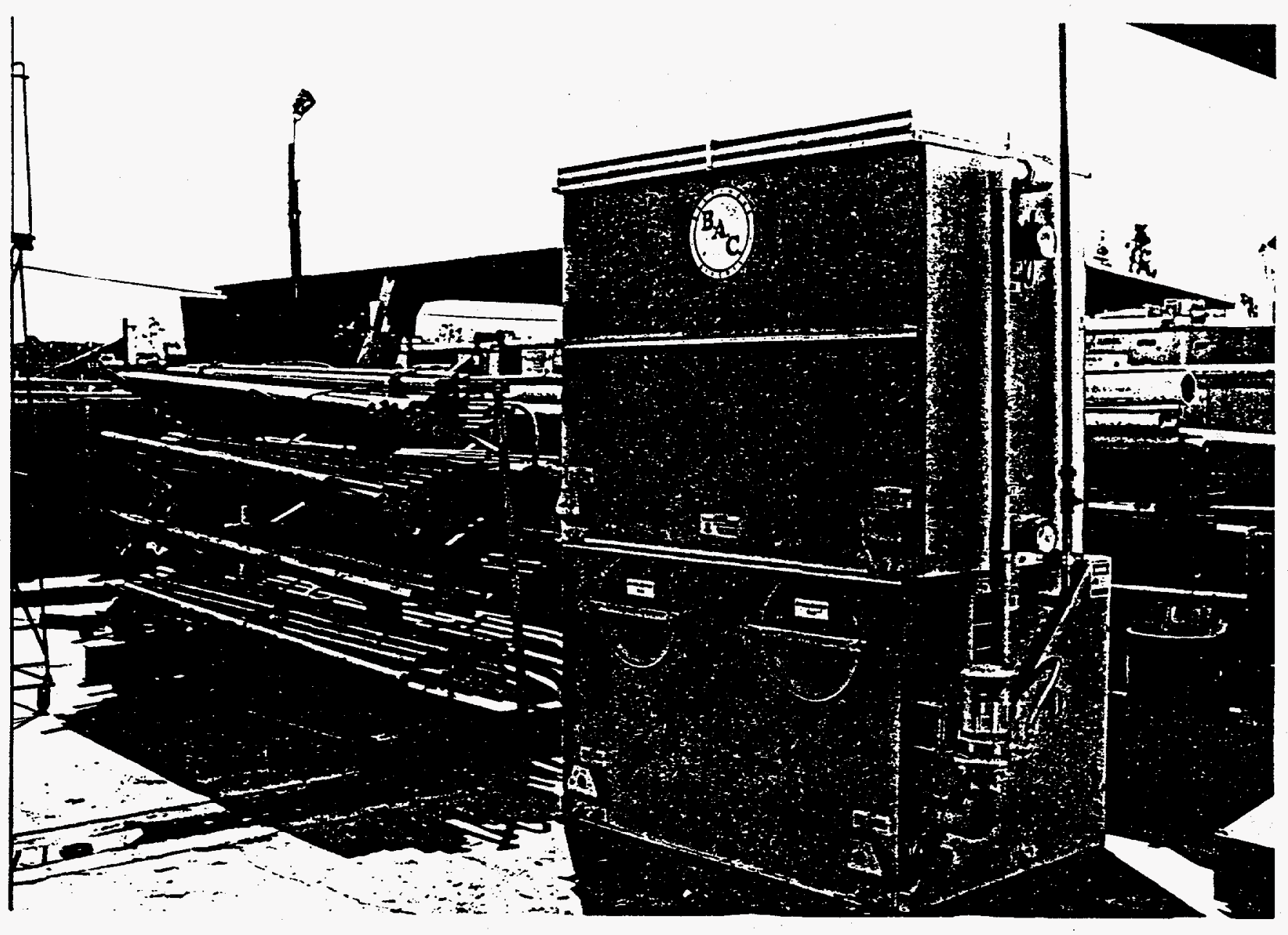

FIGURE 2: AIR-COOLED EVAPORATIVE IIFIT EXCIIANGER 

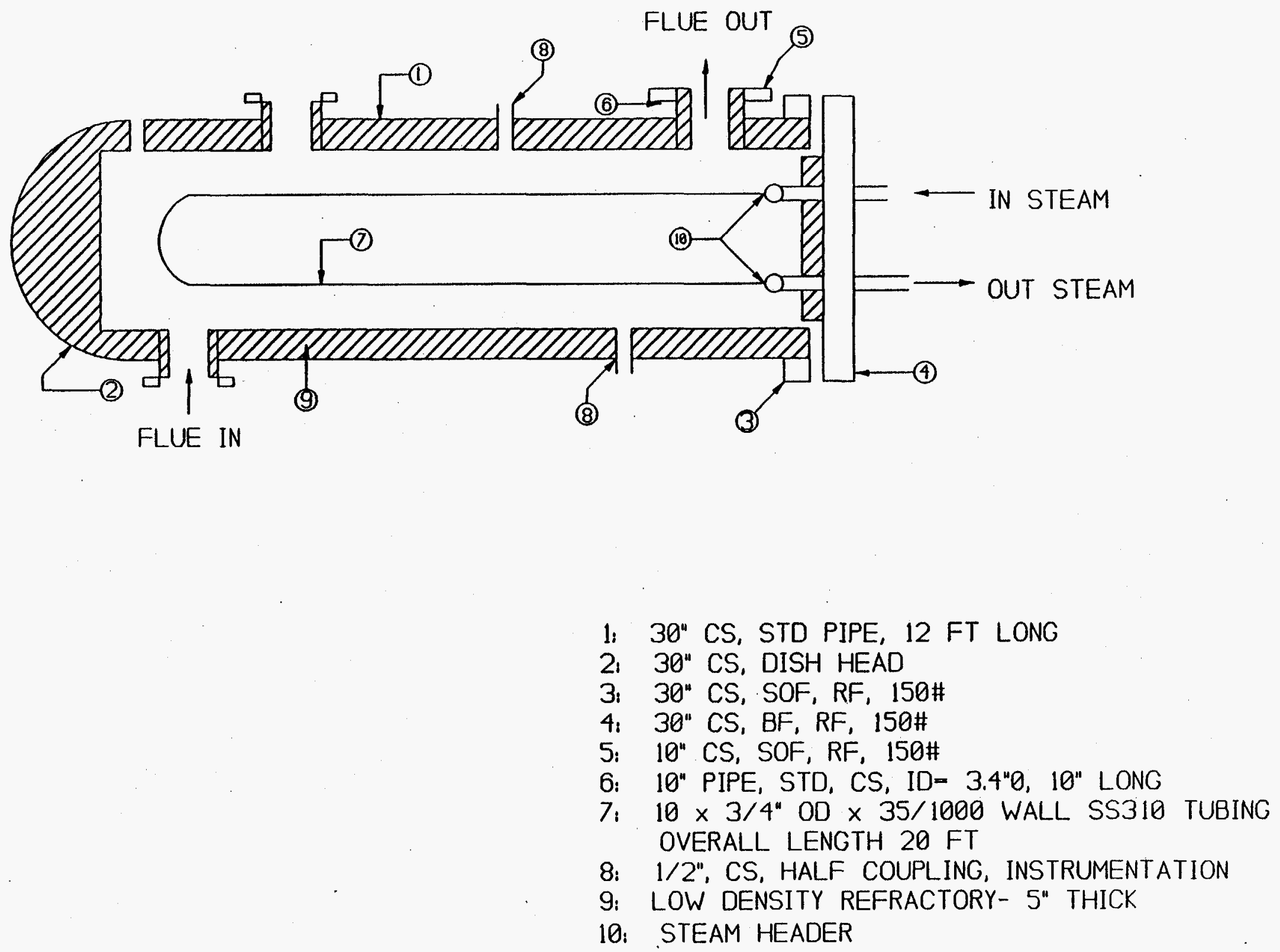
$-280-$ 


\title{
"ENVIRONMENTAL POLLUTION CONTROL DEVICES BASED ON NOVEL FORMS OF CARBON"
}

\author{
Quarterly Report for Period \\ thru March 31, 1995
}

Work Performed Under Project No::

MC-17 as Part of the WUU-DOE Cooperative Agreement,

DE-FC21-92MC29467

For

U. S. Department of Energy

Morgantown Energy Technology Center

Morgantown, West Virginia

\section{By}

Albert Brennsteiner, WWU, Department of Chemical Engineering John W. Zondlo, WUU, Department of Chemical Engineering Alfred H. Stiller, WUU, Department of Chemical Engineering

Peter G. Stansberry, WWU, Department of Chemical Engineering Dacheng Tian, WUU, Department of Chemical Engineering

R. Terry K. Baker, PSU, Materials Research Department Nelly M. Rodriguez, PSU, Materials Research Department

West Virginia University

Morgantown, West Virginia 26506

March 1995 
$-282-$ 


\section{ABSTRACT}

The use of electrochemistry is an effective means to remove heavy metal contaminants from aqueous effluent streams. Electrochemical processes also exist for the removal of salts as well as bacteria and organic compounds form water. This project deals with the development and testing of carbon nano-fibers for the cathodic removal of heavy metals from the effluent stream.

The concentration of heavy metal ions in the effluent stream is usually very low. 1 to $1000 \mathrm{ppm}$. These low concentrations lead to relatively low current densities and low conversion of electroactive species at electrodes with small surface area. Therefore, the electrolytic cell must be designed to increase the degree of conversion of the electroactive species (metal ion) as it passes through the cell. This increase in conversion can be obtained by two means; (1) the use of a 3-dimensional electrode (increases surface area and residence time) and (2) turbulence (rotated electrode or flowing stream). The desire is to create a very high ratio of electrode surface area to electrolyte volume within the cell, coupled with turbulent mass transport within the cathode material. In this type electrode, it is possible to control the conversion efficiency using the length of electrode through which the effluent solution must pass.

This work is to develop and test a cathodic material with an extremely large ratio of surface area to electrolyte volume. This will be accomplished by using a packed-bed of carbon nano-fibers or by growing carbon nano-fibers on a conductive support. The surface area can be increased by 2-3 orders of magnitude. This increased surface area can help minimize the length of electrode through which the solution must pass. This decreased distance leads to reduced resistance to solution flow.

All experimental parameters will be optimized for the removal of cadmium, lead and copper from laboratory prepared samples using a small-scale model of the electrolytic cell. Subsequent work shall examine the use of this electrolytic cell on "real" samples and for the selective removal and recovery of precious metals. The final objective will be to transfer this technology for use in industrial applications. 
$-284-$ 
SECTION

PAGE

Disclaimer

ii

Abstract

iii

List of Tables

vi

List of Figures

vii

Executive Summary

viii

Introduction

1

Purpose

1

Background

1

Experimental Methodology

2

Metal Removal Cell

2

Detector Cell

3

Samples

Carbon Nano-Fibers

Vapor Grown Carbon Fibers

Reticulated Vitreous Carbon

Work Performed This Period

Experimental

Surface Area 
Reagents

Procedure

Results and Discussion

Conclusions

Work Planned for Next Period

Technical / Administrative Difficulties

References 


\section{LIST of TABLES}

\section{TABLE}

PAGE

Table I Standard Reduction Potentials of Metal lons

Table II Properties of Vapor Grown Carbon Fibers

Table III Properties of Reticulated Vitreous Carbon

Table IV Properties of Carbon Nano-Fibers

Table V Properties of Carbon Nano-Fibers Grown on Graphite Fiber Mats

Table VI Percentage of Project Completion 


\section{LIST of FIGURES}

FIGURE

PAGE

Figure 1 Electrochemical Remediation Cell and Detector

Figure 2 Thin-Layer Flow Cell 3

Figure 3 Modified Remediation Cell 9

$\begin{array}{lll}\text { Figure } 4 & \text { ASV Response for Cadmium, Lead and Copper at a MFE } & 10\end{array}$

$\begin{array}{lll}\text { Figure } 5 \text { Dependence of Peak Current on Deposition Time } & 10\end{array}$

$\begin{array}{lll}\text { Figure } 6 \text { Dependence of Peak Current on Scan Rate } & 10\end{array}$

$\begin{array}{lll}\text { Figure } 7 & \text { Calibration Curve for Lead } & 11\end{array}$

$\begin{array}{lll}\text { Figure } 8 & \text { Precision of Copper and Lead Responses } & 11\end{array}$

$\begin{array}{lll}\text { Figure } 9 & \text { Performance of RVC for Metal Removal }\end{array}$

Figure 10 Performance of Carbon Nano-Fibers Grown on Graphite Mats 


\section{EXECUTIVE SUMMARY}

Flow electrolysis using carbon nano-fibers, either loosely or grown on a conductive support, was employed for decontaminating heavy metal solutions. Reduction of $\mathrm{Cd}(\mathrm{II}), \mathrm{Pb}$ (II) and $\mathrm{Cu}$ (II) ion concentrations in aqueous solutions was carried out under controlled flow and potential conditions. Removal efficiencies of $90 \%$ and greater were obtained using carbon nano-fibers grown and graphite fiber mats. For initial metal ion concentrations of $100 \mathrm{ppb}$, this corresponds to an effluent metal ion concentration at the outlet of the electrolytic cell of $10 \mathrm{ppb}$ or less. The decrease in metal ion concentration was monitored using Anodic Stripping Voltammetry (ASV) downstream from the electrolytic cell. The performance of the carbon nano-fibers competes with prevalent metallic and carbonaceous metal removal systems. The ease with which modifications and optimizations can be

accomplished makes this a simple and economic method for metal ion removal and recovery. 
$-290-$ 


\section{ELECTROCHEMICAL STUDY OF CARBON NANO-FIBERS}

\author{
INTRODUCTION
}

\section{PURPOSE}

The purpose of this research is to assess the feasibility of using carbon nano-tube devices to remove heavy metal contaminants from aqueous streams. This work will address the fabrication, behavior and analytical utility of these novel carbonaceous materials. Standard electrochemical techniques will be employed to meet this objective.

\section{BACKGROUND}

Electrochemical techniques pertain to measurements involving the flow of electrons during a reduction-oxidation (redox) reaction. These measurements involve current, potential, charge and/or time as the primary variables. Electrochemical studies typically incorporate the use of a three electrode system. This systems includes a working, reference and auxiliary electrode. The redox reaction occurs at the surface of the working electrode as a result of the applied potential. Therefore, it is critical to choose a suitable material for the working electrode. The material must meet certain requirements. The electrode material should exhibit high electrical conductivity, be chemically inert over the potential region of interest, show favorable electrochemical behavior with the analyte(s), have a low background current and have an easily reproducible surface (1). Carbon materials are well suited for use as working electrodes. Graphite $(2,3)$, carbon paste (4), glassy carbon (5) and reticulated vitreous carbon (RVC) (6) are a few examples of carbonaceous materials that have been used. A detailed discussion of carbon electrodes has been compiled by Dryhurst and McAllister (7).

Carbonaceous materials have been used to produce flow-through porous electrodes. Electrode materials have included graphite chips (8) or granules (9), glassy carbon grains (10), crushed graphite (11), screens of graphite (12) or carbon (13) and RVC (14). These porous flow-through electrodes have been used to remove metal ions from aqueous solutions. This is of major importance to industrial processes and environmental applications.

The large surface area of porous flow-through electrodes makes them excellent candidates for the removal of metal ions from solution. Removal efficiencies approaching $100 \%$ can be achieved (14). The present work will address the use of various carbon materials, including carbon nano-fibers to produce porous flow-through electrodes for the removal of metal ions from aqueous media. The resulting effluent will be monitored downstream using anodic stripping voltammetry to assess the decrease in analyte concentration and hence the electrode efficiency. 


\section{EXPERIMENTAL METHODOLOGY}

A schematic diagram of the apparatus used to carry out these experiments is shown in Figure 1 . It was designed in our lab and was produced by our machinist. It is a two-cell system.

The upstream, working cell removes metal ions from the flowing stream. The downstream, analytical cell is used to measure the metal ion concentrations in the resulting effluent. The analysis of the analyte concentration leaving the working cell will be measured on-line by anodic stripping voltammetry. This is necessary since the concentration of the metal ions leaving the working cell is expected to be in the parts-per-billion (ppb) range and such an analytical cell is essential to obtain sensitive and accurate measurements at these low concentration levels. A typical 3-cell electrode system, using a silver/silver chloride $(\mathrm{Ag} / \mathrm{AgCl})$ reference electrode will be used for all studies.

\section{METAL REMOVAL CELL}

The upper cell is used to test the various carbonaceous electrode materials for their ability to remove certain heavy metal ions from an aqueous stream. The cylindrical body of the upper (working) flow-through cell was made of Plexiglas.

A solution flow channel was drilled through the Plexiglas body. The working electrode material is held in place by glass wool or by a snug fit, dependent upon the nature of the material. Contact to the working electrode is accomplished using a platinum wire through an access port in the Plexiglas wall. The $\mathrm{Ag} / \mathrm{AgCl}$ reference electrode and platinum wire auxiliary electrode are introduced into the flow channel by similar access ports in the wall. Teflon tubing is used to connect the sample reservoirs, the pump and the upper and lower cells.

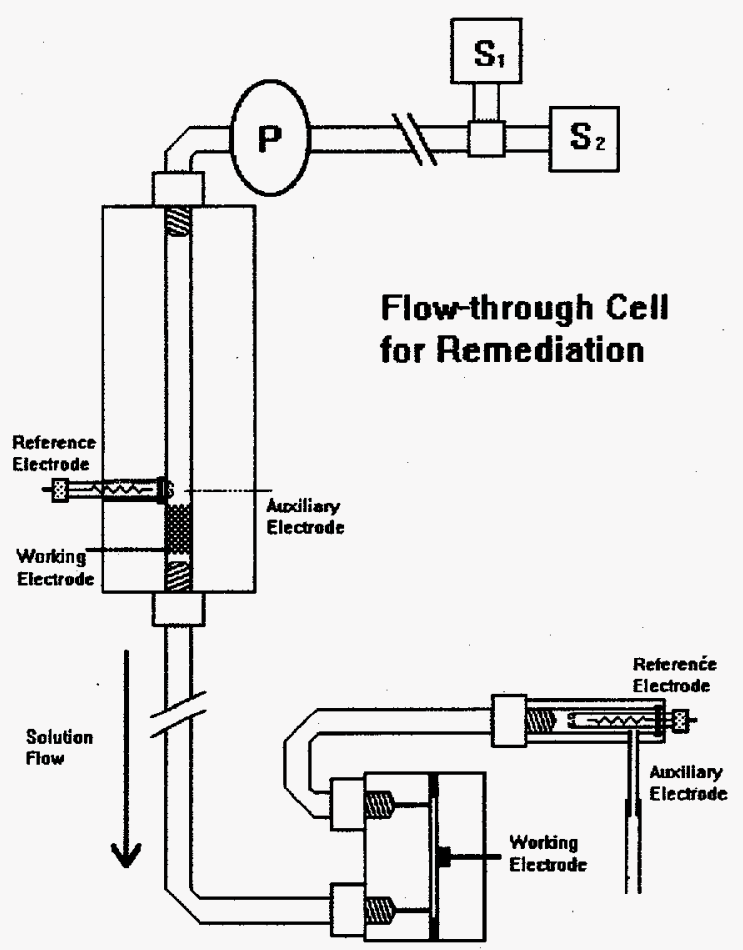

Downstream Detector

FIGURE 1:

Electrochemical Remediation Cell and Detector ( $P=$ pump; $S=$ sample)

The sample is pumped into the upper working cell and through the carbonaceous working electrode material. A peristaltic pump is used to control the flow rate for all experiments. An applied potential more negative than the standard reduction potential of the metal ions of interest is applied to the working electrode. This applied potential forces the plating of the metals onto the electrode surface thus removing the 
contaminant metals from solution. Experimental parameters will be optimized to maximize the removal of these metals. These parameters include $\mathrm{pH}$, buffer concentration, solution flow rate (V) and applied potential (E). Conversion efficiency, long-term stability and loading capacity will also be assessed. Finally, the pressure drop and flow rate characteristics of the solution flowing through the upper cell will be assessed.

\section{DETECTOR CELL}

The lower flow detector (analytical cell) is used to determine metal ion concentration in the effluent stream. The detector working electrode is a glassy carbon disk. The reference electrode is $\mathrm{Ag} / \mathrm{AgCl}$ and the stainless steel body of the cell acts as the auxiliary electrode (Figure 2). A thin mercury film is deposited onto the working electrode surface by applying a negative potential (usually $-1.00 \mathrm{~V}$ ) while a solution containing mercuric ions $\left(\mathrm{Hg}^{2+}\right)$ flows past the glassy carbon electrode. Mercuric ions are reduced to mercury metal forming a thin film of mercury on the glassy carbon surface. The mercury film preconcentrates the metal ions of interest (i.e. $\mathrm{Cd}, \mathrm{Pb}, \mathrm{Cu}$ and $\mathrm{Zn}$ ) at the electrode surface prior to measurement. The metal ion concentration in the mercury film can be 10-100 times greater than the metal ion concentration in the effluent steam. In order to accumulate the metal ions, the mercury solution flow is stopped and the analyte solution is passed over the mercury-coated disk.

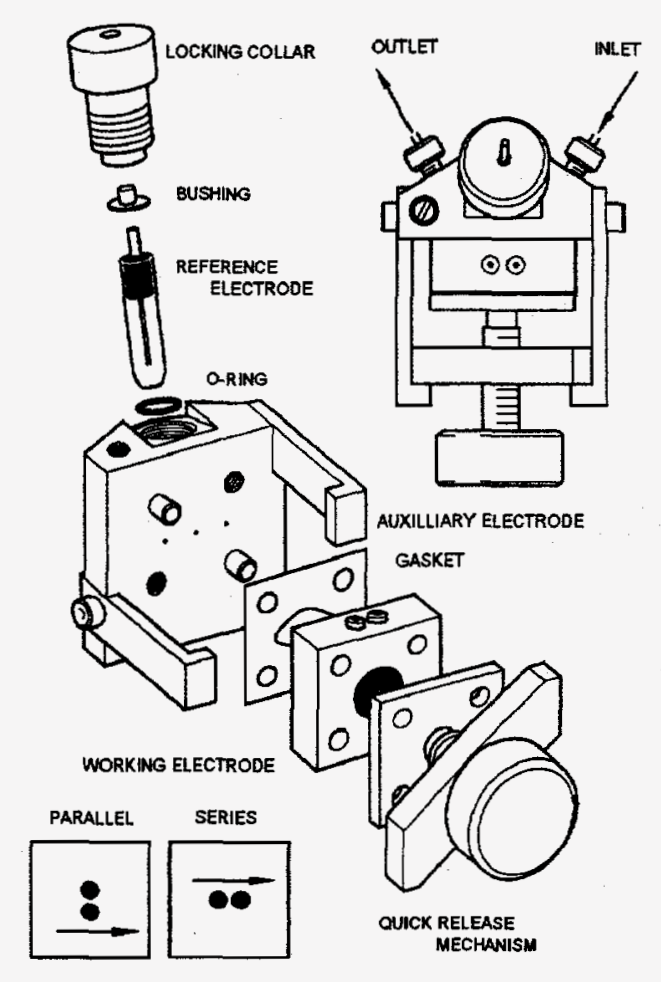

FIGURE 2:

Thin-layer Flow Cell for Metal Detection

A potential more negative than the standard reduction potential of the metals being removed is applied to the glassy carbon working electrode as the effluent stream flows past. Any metal ions not removed by the upper flow-through cell will be preconcentrated into the mercury film at the detector. The metal ions are subsequently stripped (removed) from the mercury film by scanning the potential in the positive direction. This forces the oxidation of the metal ions near their standard redox potential. The electron transfer involved in this oxidation is measured as a current flow at the working electrode surface. The current response obtained from this anodic stripping of the metals from the mercury film is used to determine the metal ion concentration of 
the effluent stream. Once the concentration is known, the efficiency of the upper flow-through cell and hence the carbon material under test can be evaluated. In order to determine the metal ion concentration, the flow rate through the upstream working cell and the downstream analytical cell must be measured accurately. This is accomplished by collecting a known amount of the solution at the cell outlet in a precisely calibrated graduated burette while measuring the time using a stopwatch. Accurate and reproducible flow rates are calibrated to onehundredths of a milliliter.

An important feature of this system is that it allows continuous, on-line monitoring of the analyte species in the effluent steam. Measurement of metal ion concentration levels down to and below $0.2 \mathrm{ppb}$ are possible with this detection method dependent upon the metal under investigation.

\section{SAMPLES}

Several carbonaceous electrode materials have been obtained from a variety of sources for comparison. To date, the following samples have been obtained:

Carbon Nano-Fibers (\#1094-A) from PSU (University Park, PA)

Carbon Nano-Fibers (\#1094-B) from PSU (University Park, PA)

Carbon Nano-Fibers grown on Graphite Fiber Mats (\#0295-A) from PSU (University Park, PA)
Vapor Grown Carbon Fibers (VGCF) (PYROGRAF III, Lot ADNH-104107) from Applied Sciences, Inc. (ASI, Cedarville, $\mathrm{OH}$ )

Reticulated Vitreous Carbon (RVC) foam (Duocel ${ }^{\circledR}, 3 \%$ density) from Energy Research and Generation, Inc. (ERG, Oakland, CA). $(10,20,30,45,80$ and $100 \mathrm{ppi)}$

The physical properties of these materials are currently being measured. Tables I-III show some of the properties exhibited by these materials. Each additional sample will undergo similar characterization as it is received. All samples are characterized and tested as received without any further treatment unless otherwise noted.

\section{CARBON NANO-FIBERS}

The carbon nano-fibers were produced by our collaborators at Pennsylvania State University (PSU) under the supervision of Dr. R. Terry K. Baker. This new type of fibrous material is generated using the catalytic carbon vapor deposition technique. The nanofiber material is a microscopic version of carbon fibers. It is produced by the metal catalyzed decomposition of certain hydrocarbons $(15,16)$. Various degrees of graphitization are possible. A more detailed description is included in the original project proposal.

\section{VAPOR GROWN CARBON FIBER (17)}

The VGCF manufactured by Applied Sciences, Inc. (ASI) are produced 
by a combination of catalytic and chemical vapor deposition processes which allow for control of the fiber dimensions, such as filament length and diameter. Lengths are available from 1 $\mathrm{mm}$ to tens of centimeters and diameters can vary from under 0.1 to over $100 \mathrm{~mm}$. The resulting fiber has a lamellar morphology and is highly graphitic. VGCF can be heat treated to further improve the graphitization. These improvements can be readily seen in Table I. Cross section and overall views of these samples were provided in the first quarterly report.

\section{RETICULATED VITREOUS CARBON} (RVC) (18)

\section{Reticulated Vitreous Carbon} (RVC) is an open-pore material with a honeycomb (foam) structure (14). RVC is a form of carbon that combines some of the properties of glass with normal industrial carbon. RVC has a large void volume $(97 \%)$ and large surface area $\left(0.09 \mathrm{~m}^{2} / \mathrm{gram}\right)$. It has a self-supporting rigid structure, a low resistance to flow and is resistant to temperatures up to 600 ${ }^{0} \mathrm{~F}$ in air $\left(6330{ }^{\circ} \mathrm{F}\right.$ in a non-oxidizing environment) (19). A more thorough discussion of vitreous carbon is available in the literature (20-24). The samples obtained had various pores sizes. Sizes included $10,20,30,45,80$ and 100 ppi (pores per inch). The $100 \mathrm{ppi} \mathrm{RVC} \mathrm{foam}$ will be analyzed in our study.

All materials were used as received without any further pretreatment. If necessary to help activate or clean the surface, mild electrochemical or chemical methods will be employed.

\section{WORK PERFORMED THIS PERIOD}

\section{EXPERIMENTAL}

\section{Surface Area}

The surface area of the samples has been determined. The surface areas were obtained using a Gemini III 2375 Surface Area Analyzer (Micrometrics Instrument Corporation, Norcross, GA). Standard operating procedures have been followed as outlined in the operator's manual.

A pre-weighed sample of the carbonaceous material was placed into a clean, dry sample tube. The sample was thoroughly degassed using nitrogen. The dewar was filled with liquid nitrogen and the system prepared for analysis.

The sample tube was connected to the analysis port and the balance tube was connected to the balance port. Care was taken to minimize exposure of the sample to air. The doors to the sample station were closed and the analysis initiated. Saturation pressure was set to $740.53 \mathrm{~mm} \mathrm{Hg}$ and the evacuation rate to $599 \mathrm{~mm} \mathrm{Hg} / \mathrm{min}$. The Gemini III 2375 Surface Area Analyzer performs automated analysis. It is capable of simultaneously performing BET multipoint and single point surface area, Langmuir surface area, t-method micropore, and BJH adsorption/desorption distribution. The resulting data was recorded on an Epson plotter (Model P84FA). 


\section{Electrochemical Apparatus}

\begin{abstract}
A two-cell system is used for this study. The upper, or working cell removes metal ions from the flowing stream. The downstream or analytical cell is used to assess the performance of the working cell by measuring the metal ion concentration in the effluent. The upper flow-through cell design is shown in Figure 1. The cylindrical body of the upper cell is made of Plexiglas $(1.9 \mathrm{~cm}$ diam., $8.0 \mathrm{~cm}$ length). The flow channel $(0.90 \mathrm{~cm}$ i.d.) was drilled through the Plexiglas body. The $\mathrm{Ag} / \mathrm{AgCl}$ reference electrode (3M NaCl, Model RE-4, BioAnalytical Systems, Inc. (BAS) West Lafayette, IN) is introduced into the flow channel through a Plexiglas sleeve positioned 90 degrees to the flow channel. Leakage is prevented using an O-ring and compression-type fitting. A stainless steel fitting (Swagelok, Niagara Falls, ONT) at the top of the cell is used as the auxiliary electrode. Contact to the working electrode is established via platinum mesh positioned through the cell wall and sealed with an o-ring.
\end{abstract}

The thin-layer flow cell, as shown in Figure 2, was purchased from BioAnalytical Systems (Model LC-4401000). The working electrode is a glassy carbon disk ( $0.3 \mathrm{~cm}$ diameter) over which the solution flows. Two $50 \mu \mathrm{m}$ spacers are used to produce the flow channel and direct the effluent flow across the carbon disk. The glassy carbon disk is polished using successive slurries of 1 , 0.3 and $0.05 \mathrm{~mm}$ alumina until a mirrorlike surface is obtained. The glassy carbon electrode is then washed thoroughly with deionized water. All potentials are measured relative to the
$\mathrm{Ag} / \mathrm{AgCl}$ reference electrode (BAS). The thin-layer flow cell is connected to the upper cell using Teflon tubing so that the effluent from the working cell flows to the bottom analytical cell.

Solution reservoirs for the mercury (II) plating solution and samples are $1000 \mathrm{ml}$ Nalgene jars fitted with covers. The solution reservoirs are connected to the working cell using Tygon tubing. Solution flow is controlled with a peristaltic pump (Cole-Parmer Instrument Co., Niles, IL) located upstream from the upper cell. All solutions were deaerated using nitrogen gas prior to use. A nitrogen head space is maintained above the solutions to prevent the re-dissolution of oxygen.

The potential of the upper flow-through cell is controlled using an BAS Model PWR-3 Power Module. Stripping voltammograms at the thin-layer flow cell are obtained using the EG\&G Model 263A Potentiostat/Galvanostat in conjunction with a HP Model 7044b X-Y recorder.

\section{Reagents}

Stock solutions of $1 \mathrm{ppm} \mathrm{Cd}, \mathrm{Pb}, \mathrm{Cu}$ and $\mathrm{Zn}$ ions are prepared using standard solutions (1000 ppm, Fisher Scientific, Fair Lawn, NJ) and deionized water. These solutions are stored in polyethylene containers to avoid contamination. Portions of these solutions are diluted as needed for experimentation. The $1 \times 10^{-4} \mathrm{M} \mathrm{Hg}$ (II) solution used for mercury plating is prepared from $\mathrm{Hg}\left(\mathrm{NO}_{3}\right)_{2}$ as needed. The mercury ion and sample solutions are prepared in $0.1 \mathrm{M} \mathrm{KNO}_{3}$ supporting 
electrolyte. The $\mathrm{pH}$ is adjusted to 3.9 using $\mathrm{HNO}_{3}$. (All chemicals were certified ACS grade purchased from Fisher Scientific unless otherwise noted).

\section{PROCEDURE}

\section{Metal Removal Cell}

The carbon material to be studied was pretreated to oxidize and assist in the wetting of the carbonaceous surface.

This was accomplished by placing the carbon material in a dilute solution (1M) of nitric acid overnight in a covered beaker. The material was then thoroughly washed using distilled-deionized water. The carbonaceous material was then positioned into the lower end of the flow channel in the upper working cell using a clean glass rod. Glass wool was packed below fibrous samples to support them and prevent them from flowing out of position. Various thicknesses of the carbon nano-fibers (1094-A) were packed into the flow channel using different amounts of force. The particles were packed loosely, lightly and tightly. Loosely packed nano-fibers showed little resistance to solution flow, but did not establish a good electrical contact to the platinum wire. Tightly packed nano-fibers resulted in good electrical contact but stopped solution flow. Lightly packed carbon nano-fibers produced some resistance to solution flow but irreproducible electrical contact. A procedure will be developed to pack the carbon nano-fibers so that the resistance to solution flow is minimized while good electrical contact is maintained.
Using the new cell design, it is not necessary to use glass wool to pack the fibrous carbon nano-fiber material. The threaded plug is used to press the material between a platinum mesh and a piece of filter paper. The carbon material is placed into the working cell and the threaded plug is screwed into place snugly against it. The pressure on the carbon nano-fibers can be easily adjusted by turning the threaded plug. Rigid samples, such as Reticulated Vitreous Carbon were positioned using a snug fit. Electrical contact to the working electrode material was established using the platinum wire. The reference electrode was inserted into the sleeve and the cell was connected to the pump using Tygon tubing. $\mathrm{A} 0.1 \mathrm{M} \mathrm{KNO}$ electrolyte solution was pumped through the flow cell. In order to help remove air bubbles and wet the electrode surface, a mild electrochemical pretreatment was used. The cell potential was held at $+1.00 \mathrm{~V}$ for 10 minutes followed by $-1.00 \mathrm{~V}$ for 10 minutes.

The performance of the carbonaceous material under study was tested by placing a solution containing a known concentration of metal ions ( $\mathrm{Cd}$, $\mathrm{Pb}$ and/or $\mathrm{Cu}$ ) into the sample reservoir. The solution was then allowed to pass through the metal removal (working) cell at a known flow rate and applied potential.

The performance was assessed by measuring the metal ion concentration in the effluent and comparing it to the initial ion concentration. The percentage efficiency of the cell is equal to the percentage of metal ions removed from the solution by the electrolytic cell. 
For the preliminary studies, the effluent was collected in a Nalgene bottle for subsequent analysis using the downstream analytical cell.

\section{Detector Cell}

A pre-plated mercury film is used for downstream anodic stripping voltammetric (ASV) detection of the metal ions in the effluent stream. A $1 \times 10^{-4} \mathrm{M}$ $\mathrm{Hg}$ (II) solution in $0.1 \mathrm{M} \mathrm{KNO}_{3}$ is purged with nitrogen for 20 minutes. The mercury film is produced by applying a potential of $-1.00 V$ at the glassy carbon electrode while passing the $\mathrm{Hg}(\mathrm{II})$ solution through the cell at $0.87 \mathrm{ml} / \mathrm{min}$ for 5 minutes. After this period, the potential is held at $+0.05 \mathrm{~V}$ for 90 seconds. Following this conditioning, the stopcock is turned to stop the flow of mercuric ions and allow the flow of the deaerated sample through the cell. This flow is continued for 3 minutes to flush any mercuric ions from the system and replace all of the solution in the system with the sample to be studied.

While the solution is flowing at a known flow rate, the ASV plating potential is applied to the thin-layer flow cell (usually for 1 minute) and the metal ions are accumulated. At this point, the solution flow is stopped to the analytical cell and after a 30 second equilibrium period, a potential ramp is initiated $(-1.00$ $V$ to $+0.200 \mathrm{~V}$ ) and the stripping voltammogram recorded. The scan is terminated at $+0.200 \mathrm{~V}$. Sample solution flow is renewed and the electrode cleaned for 90 seconds to prepare the system for the next determination.
The mercury film and plated metals are removed at the end of a series of experiments using a moist Kimwipe. The electrode is subsequently polished for the next series of studies.

\section{RESULTS and DISCUSSION}

After preliminary testing of the initial cell design (as shown in Figure 1), it was found that some modifications were required.

First: If varying thicknesses of carbonaceous electrode material are to be tested, the distance between the working and the reference electrodes would not be constant. This would lead to differences in the solution resistance and therefore, differences in uncompensated potential (iR) losses.

Second: There was great difficulty in establishing good electrical contact between the working electrode material (the carbon nano-fibers) and the Pt wire lead. This problem induced large cell resistance and high voltage drops across the carbon electrode.

In order to maintain a constant distance between the working electrode and the reference electrode and minimize cell resistance, a new cell design was created. This new design is shown in Figure 3. 


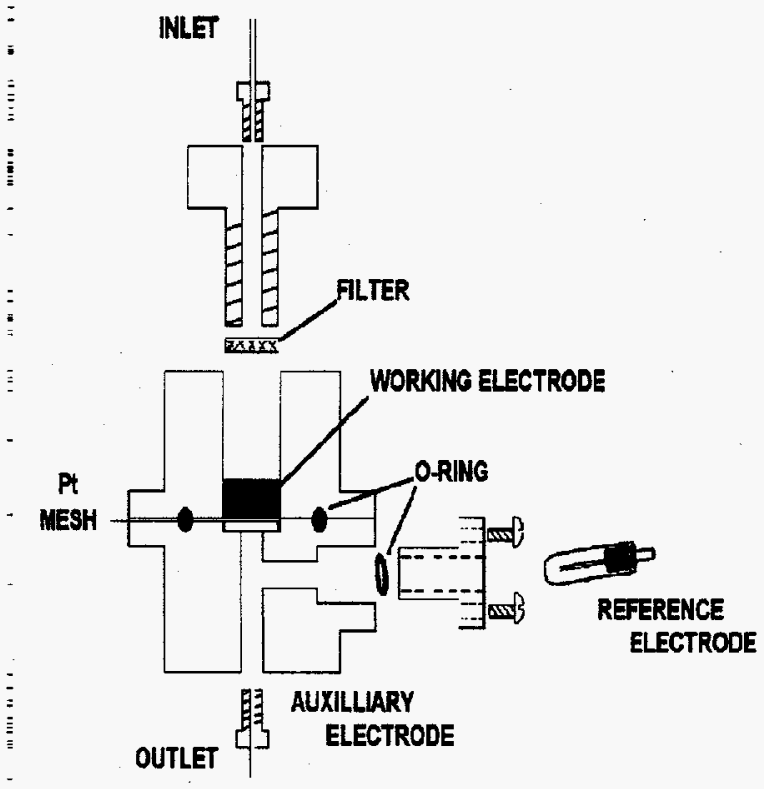

FIGURE 3:

Modified Remediation Cell

A threaded plug will be used to press the carbonaceous working electrode material firmly against a $\mathrm{Pt}$ mesh. This platinum mesh will be used as the working electrode contact. The surface area of the platinum mesh is negligible relative to the surface area of the carbon material, but should still afford much better contact with the carbonaceous material than the single $\mathrm{Pt}$ wire used in the previous design. Therefore, minimal electrolytic contribution will be gained from the platinum mesh while maximizing the electrical contact. The reference electrode was positioned as close as possible to the working electrode through a Plexiglas sleeve. Special care was taken to allow varying amounts of carbon material to be used, while maintaining constant electrode distances. Through the use of flanges and an o-ring, the design also allows easy removal and replacement of the carbon material.

A major complication involved the loading of the carbon nano-fibers in the earlier cell. Loosely packed carbon-fibers allowed solution flow, but electrical contact was sacrificed. If the particles were packed more tightly, improved (although not great) contact was established, but a high resistance to solution flow resulted. Further work is being performed to help eliminate this problem. One step taken in the new cell design is the addition of a threaded plug so that the amount of compression of the nano-fibers can be adjusted and controlled.

\section{ANALYTICAL CELL}

The inherent sensitivity of Anodic Stripping Voltammetry makes it an excellent choice for the detection of heavy metal ions in solution. The detectable limits are often below those attainable using Flame and/or Flameless Atomic Absorption / Emission Spectroscopy. Figure 4 demonstrates the ability to detect these low limits using a thin mercury film coated on a glassy carbon electrode. The mercury film yields well-defined and sharp peaks, good resolution between neighboring signals and a low background current. The response shown is for a sample solution containing 10 parts per billion (ppb) cadmium, lead and copper in $0.1 \mathrm{M} \mathrm{KNO}_{3}$ at various deposition times $(0,30,60,90$ and 180 seconds). The increased accumulation of the metals in the mercury film with time is quite evident. 


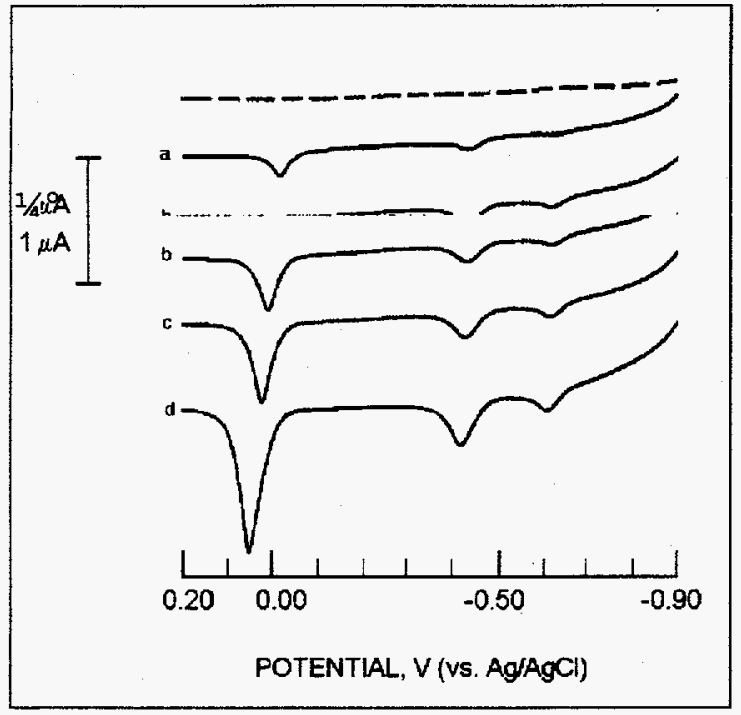

Figure 4: ASV Response for $10 \mathrm{ppb}$ Cadmium, Lead and Copper at a Mercury Film Electrode.

(Mercury Film Plating: $5 \mathrm{~min} @-1.00 \mathrm{~V}, 1 \times 10^{-4}$ M Hg(II), $90 \mathrm{sec} @+0.05 \mathrm{~V}$, flow $=0.87 \mathrm{ml} / \mathrm{min}$. ASV: Deposition: 30 (a), 60 (b), 90 (c) and 120 (d) seconds @-1.00V, $10 \mathrm{ppb} \mathrm{Cd}, \mathrm{Pb}$ and $\mathrm{Cu}$ in $0.10 \mathrm{M} \mathrm{KNO}_{3}, \mathrm{pH}=3.9$, flow $=0.87$ $\mathrm{ml} / \mathrm{min}$; $E Q$ time $=15 \mathrm{sec}$; Stripping: -1.00 to $0.300 \mathrm{~V}, 10 \mathrm{mV} / \mathrm{sec}$, stopped flow)

The dependence of the peak current on the deposition time is shown in Figure 5. The effect of the deposition time on the peak current was studied using a solution containing $100 \mathrm{ppb}$ cadmium and lead. As expected, a linear relationship was obtained with a slope of $2.293 \mu \mathrm{A} / \mathrm{min}(\mathrm{Cu})$ and $1.180 \mu \mathrm{A} / \mathrm{min}(\mathrm{Pb})$ with correlation coefficients of $0.9937(\mathrm{Cu})$ and $0.9926(\mathrm{~Pb})$. The peak current is used to calculate the concentration of metal ions in the effluent stream.

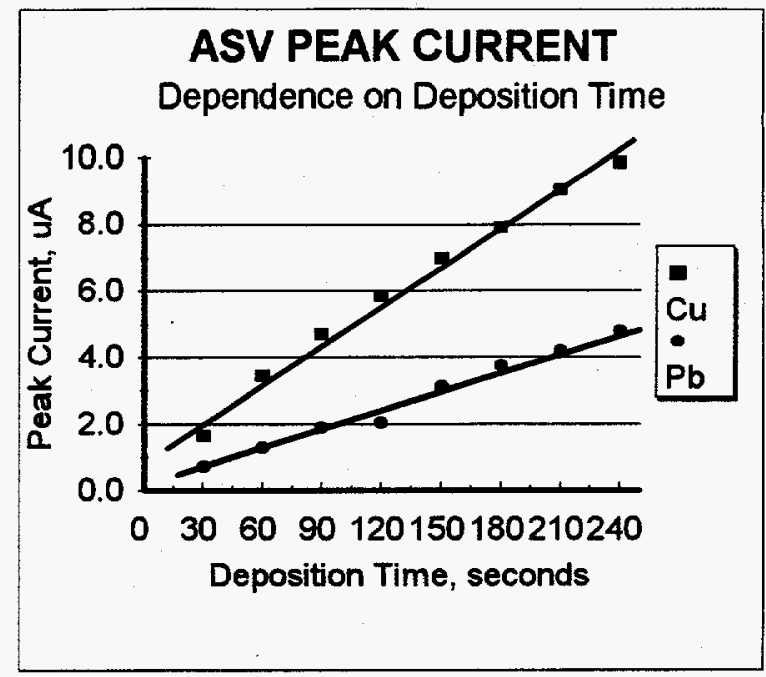

Figure 5: Time Study

(Conditions: same as Figure 4.

$100 \mathrm{ppb} \mathrm{Pb}$ and $\mathrm{Cu}$ )

Figure 6 examines the effect of the ASV scan rate on the stripping response of $100 \mathrm{ppb}$ copper and lead. the peak current increases with the increased scan rate. However, at scan rates above 10 $\mathrm{mV} / \mathrm{sec}$, the peaks begin to broaden, leading to an overlapping of neighboring peaks.

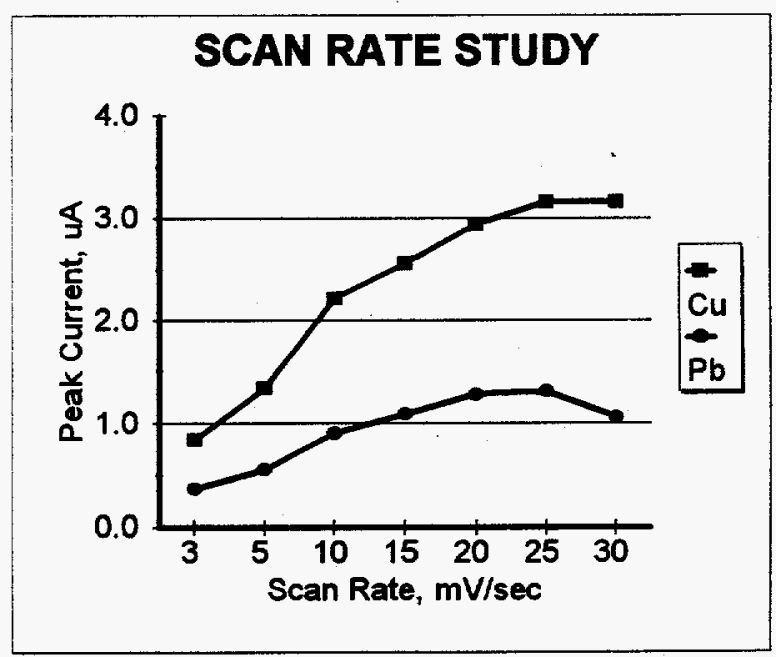

Figure 6: Scan Rate

(Conditions: same as Figure 4, 30 second deposition $100 \mathrm{ppb} \mathrm{Pb}$ and $\mathrm{Cu}$ ) 
Calibration data acquired with a flowing $(0.87 \mathrm{ml} / \mathrm{min})$ solution of lead $(1-5$ ppm) yielded well-defined and sharp peaks. The resulting calibration plot (Figure 7), was highly linear $(R=0.9932)$, with a slope of $1.066 \mu \mathrm{A} \cdot \mathrm{L} \mu \mathrm{g}$.

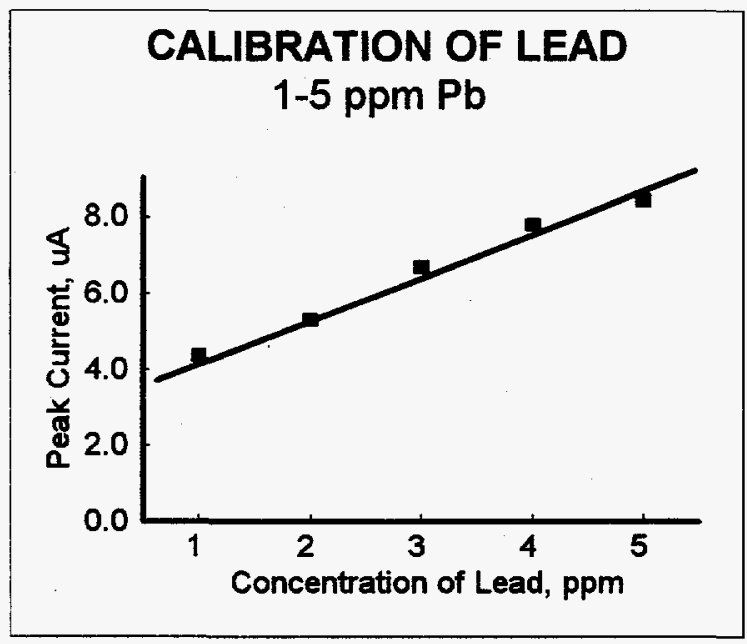

Figure 7: Calibration of Lead (Conditions: same as Figure 4. 2 minute deposition)

The response for 6 repetitive measurements of cadmium, lead and copper was examined. Figure 8 shows the exceptional precision of the response for 30 second deposition of 2 ppm copper and lead. An average peak current and relative standard deviation of $14.413 \mu \mathrm{A}$ and $2.05 \%$ for copper and $7.272 \mu \mathrm{A}$ and $3.42 \%$ for lead demonstrate the degree of reproducibility. The precision of $1 \mathrm{ppm}$ cadmium (not shown) did not produce such outstanding results. The relative standard deviation of $7.80 \%$ illustrates this point. Fine tuning of the experimental procedure is necessary to obtain the desired response.
PRECISION OF ASV RESPONSE

2 ppm Copper and Lead

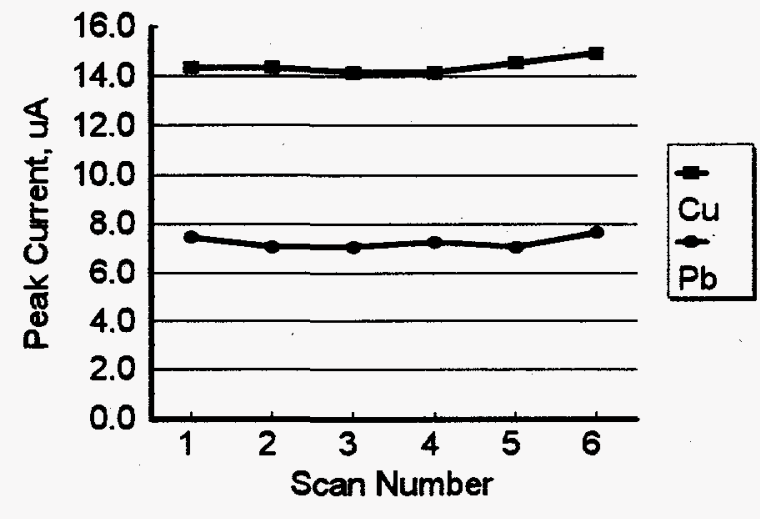

Figure 8: Precision

(Conditions: Same as Figure 4.

5 minute deposition)

\section{METAL REMOVAL}

The effectiveness of a cylindrical piece of Reticulated Vitreous Carbon (RVC) $(6 \mathrm{~mm}$ diam., $6 \mathrm{~mm}$ length) was examined for its performance as the cathode material of the upstream electrolytic (metal removal) cell. Cathodic removal of the metal ions via reductive plating on the RVC was investigated. Figure 9 shows the performance of this cell. A sample solution containing $50 \mathrm{ppb}$ cadmium, lead and copper was analyzed using a flow rate of $1.22 \mathrm{~m} / \mathrm{min}$. Curve " $A$ " shows the response of the solution prior to passing it through the electrolytic cell. Further, Curve " $B$ " shows the negligible removal of the metals ions in the cell due to adsorption alone on the carbonaceous surface $\left(E_{\text {applied }}=0.00 \mathrm{~V}\right.$ ). Only the response for cadmium was affected (16\% decrease). Upon applying a potential well negative of the reduction potentials of all three metals $\left(E_{\text {applied }}=\right.$ $-1.00 \mathrm{~V}$ ), a significant decrease in peak 
current is observed due to the removal of the metals (Curve " $\mathrm{C}$ "). A $64.7 \%$ and $50.0 \%$ efficiency was observed for copper and cadmium, respectively. A small $10 \%$ efficiency was seen for lead. At $-1.000 \mathrm{~V}$ and using a slower flow rate of 0.87 $\mathrm{ml} / \mathrm{min}$ (not shown), preliminary removal efficiencies of $90 \%$ or greater were obtained for the three metals.

In order to improve these efficiencies, several parameters must be addressed. By increasing the ratio of cathode surface area to electrolyte solution volume, increasing the time that the solution remains in the electrode material and/or by optimizing the potential applied to the cell, greater efficiencies can be obtained. One option would be

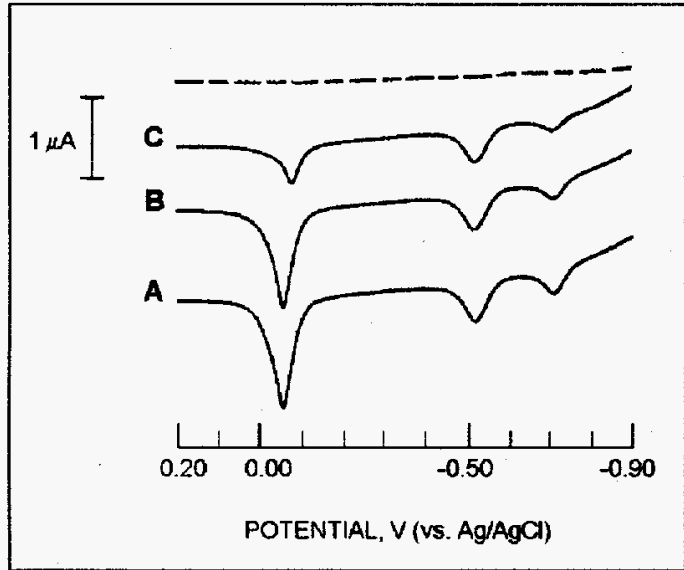

Figure 9: Metal Ion Removal Using RVC Electrode

(Conditions: Same as Figure 4. $50 \mathrm{ppb} \mathrm{Cd}, \mathrm{Pb}$ and $\mathrm{Cu}, 60$ second deposition)

(A) Metal ion solution response prior to passing through working cell.

Solution response after passing through working cell with applied potential (B) $0.00 \mathrm{~V}$ and $(\mathrm{C})$ -

$1.00 \mathrm{~V}$ (dotted line corresponds to blank solution) to lower the flow rate of the solution through the cell. This would allow more time for the metal ions to be removed, but would increase the process time. A simpler solution would be to increase the electrode surface area. This can be accomplished in any number of ways. A longer flow path through the cathode would increase the surface area and the residence time. Another method is to increase the surface area of the solid 3dimensional support by growing carbon nano-fibers onto the surface. This should produce a cathode material with a 2-3 orders of magnitude increase in surface area. Testing has begun using carbon nano-fibers grown on a graphite fiber mats produced at Penn State University. Surface area measurements of this material have been performed. Attempts by co-workers at Pennsylvania State University to grown carbon nano-fibers on the RVC surface were unsuccessful.

Initial attempts to use the loose carbon nano-fibers were halted when the Plexiglas working electrode was broken. In order to eliminate this problem, a new cell was constructed using Lexan, a more rugged material. Loose carbon nanofibers will be tested in the next quarter once the method has been "fine tuned" to establish good packing and electrical contact in the cell.

A sample of carbon nano-fibers grown on graphite fiber mats was obtained from Terry Baker at our March 17, 1995 meeting. Upon completion of the new Lexan cell, this material was prepared for analysis. The carbon nanofibers grown on graphite fiber mats were pretreated as discussed earlier to activate the carbon surface. The surface area of 
the material was then determined. The surface are was relatively large, $99.9 \mathrm{~m}^{2}$ / gram. This is one-hundred times greater than the surface area of the reticulated vitreous carbon material tested previously. This large surface area should enhance the removal efficiencies of the working cell.

The performance of this material was assessed. Good electrical contact and conductivity were obtained between the cathode material and the platinum mesh lead. The effectiveness of the carbon nano-fibers grown on graphite fiber mats to remove metal ions from an aqueous stream was then studied. The removal of the metal ions by adsorption only (no applied potential) onto the cathode resulted in minimal removal of the metal ions. Upon applying a sufficiently negative potential to the cathode, improved ion removal was attained. Figure 10 illustrates the performance of the cathode material.

Curve " $A$ " shows the response of the sample solution prior to passing it through the electrolytic cell. Curve " $B$ " shows the decrease in peak current due to the removal of the metal ions using a potential of $-0.80 \mathrm{~V}$. The response for the effluent when applying potential of $-1.00 \mathrm{~V}$ to the cell is shown in Curve " $\mathrm{C}$ ". Removal efficiencies of $99 \%, 91 \%$ and $88 \%$ were obtained for $\mathrm{Cu}, \mathrm{Pb}$ and $\mathrm{Cd}$, respectively. At an applied of $-1.20 \mathrm{~V}$, no detectable response was seen for any of the metals.

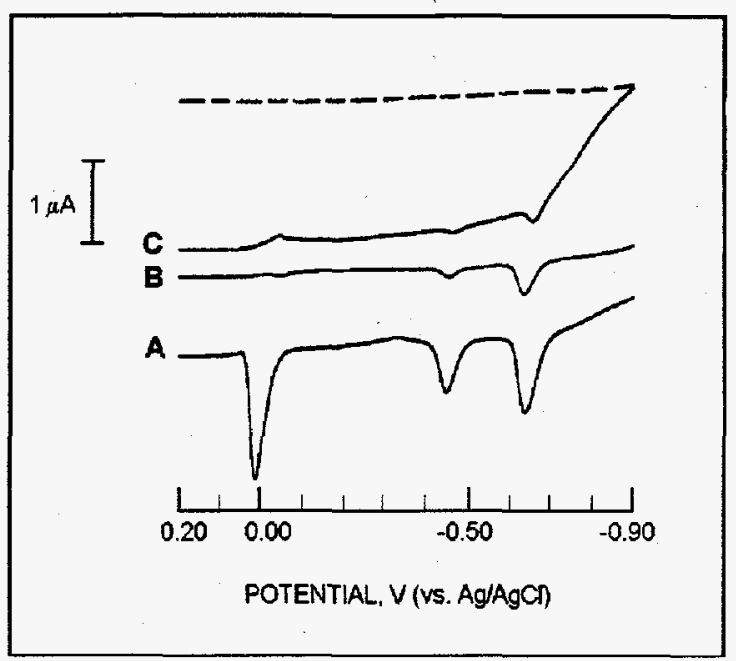

Figure 10: Metal lon Removal Using Carbon Nano-Fibers on a Graphite Fiber Mat

(Conditions: Same as Figure 4. $100 \mathrm{ppb} \mathrm{Cd}, \mathrm{Pb}$ and $\mathrm{Cu}, 60$ second deposition) (A) Metal ion solution response prior to passing through working cell. Solution response after passing through working cell with applied potential (B) $0.00 \mathrm{~V}$ and $(C)-1.00 \mathrm{~V}$ (dotted line corresponds to blank solution) 


\section{CONCLUSIONS}

In the first three quarters, we have met all of our proposed objectives to date. An extensive search of the literature has been conducted in the areas of heavy metal removal, waste water treatment and water remediation. More than 150 papers have been amassed in these areas with special interest in the areas of electrochemistry and electrowinning using carbonaceous materials.

The thin-layer flow-cell to be used as the on-line detector has been assembled and has been thoroughly tested. This testing included characterization, calibration and verification. The flow-cell will be connected on-line and used to monitor the effluent stream of the upstream metal removal cell.

The preliminary cell design for metal removal from aqueous streams has been tested. Modifications have been made to the cell design and the new cell has been produced. The modifications and problems they solve have been discussed earlier.

The performance of the RVC cell was satisfactory. Good removal efficiencies were obtained for slow flow rates. Due to the nature of growing carbon nano-fibers, the RVC could not be used as a support. The RVC was destroyed in all attempts to grow carbon nano-fibers on it. Therefore, no conclusions can be drawn on the enhanced performance due to the increase in surface area due to carbon nano-fibers grown on the surface of the RVC.
One material on which carbon nano-fibers were successfully grown, was a woven mat of graphite fibers. The carbon nano-fiber coated samples were supplied by Terry Baker at Pennsylvania State University. Surface area analysis showed that this material had a very large surface area (approximately $100 \mathrm{~m}^{2} / \mathrm{g}$ ). Analysis of this sample to remove metal ions from the aqueous sample were favorable. The carbon nano-fibers grown an graphite fiber mats performed well for removing the metal ions. Removal efficiencies of $90 \%$ and above $\left(99 \%{ }^{+}\right.$for $\mathrm{Cu})$ were easily obtained. Through the use of several mats, these metal removal efficiencies should be maintained at even higher solution flow rates due to the large increase in cathode surface area. A sample of the same graphite fiber mats is currently being acquired for comparative testing. 


\section{WORK PLANNED FOR NEXT PERIOD}

Analysis shall continue on a variety of carbon nano-fiber systems for the removal of heavy metal ions from water. Carbon nano-fibers will be grown on additional support materials and their properties tested. Bulk, loose carbon nano-fibers, as well as, the carbon nanofibers/support materials will be tested and their performance evaluated. Comprehensive preliminary screening of the samples shall be completed and suitable carbon nano-fiber materials will be selected for further development. Industrial contact will be probed for current needs to help guide the development, fabrication and implementation of this study.

A final report will be prepared summarizing the information obtained and recommendations for the continuation of the program will be evaluated.

\section{TECHNICAUADMINISTRATIVE} DIFFICULTIES

During the past quarter, a major difficulty arose concerning the funding of this project. Due to administrative circumstances, the funding for this project was frozen and our lab was unable either to purchase supplies and equipment or encumber salaries. Salaries were borrowed from other departmental sources to maintain the staff on this project. With the supplies and equipment acquired prior to this freeze, some testing was possible. 
Table I

\section{STANDARD REDUCTION POTENTIALS OF THE METAL IONS OF INTEREST}

Metal lon Reaction

$$
\begin{aligned}
& \mathrm{Zn}^{+2}+2 \mathrm{e}^{-}<=====>\mathrm{Zn}(\mathrm{s}) \\
& \mathrm{Cd}^{+2}+2 e^{-}<=====^{>} \mathrm{Cd}(\mathrm{s}) \\
& \mathrm{Cd}^{+2}+2 \mathrm{e}^{-}<=====>\mathrm{Cd} \text { (in } \mathrm{Hg} \text { ) } \\
& \mathrm{Pb}^{+2}+2 \mathrm{e}^{-}<=====\mathrm{Pb}(\mathrm{s}) \\
& \mathrm{Pb}^{+2}+2 \mathrm{e}^{-}<=====>\mathrm{Pb} \text { (in Hg) } \\
& \mathrm{Cu}^{+2}+2 e^{-}<=====^{>} \mathrm{Cu}(\mathrm{s}) \\
& \mathrm{Cu}^{+2}+2 \mathrm{e}^{-}<=====^{>} \mathrm{Cu} \text { (in } \mathrm{Hg} \text { ) }
\end{aligned}
$$

$\underline{E^{\circ},(v s, A g / A g C l)}$

$-0.986 \mathrm{~V}$

$-0.624 \mathrm{~V}$

$-0.602 \mathrm{~V}$

$-0.348 \mathrm{~V}$

$-0.343 \mathrm{~V}$

$+0.115 \mathrm{~V}$

$+0.123 \mathrm{~V}$ 
Table \|

\section{PROPERTIES of VGCF FIBERS}

Property

Fiber Diameter

Tensile Strength

Tensile Modulus

Ultimate Strain

Density

C.T.E.

Electrical Resist.

Thermal Conduct.
As Grown Heat Treated Units

0.1 through 100

2.7

400

1.5

1.8

$-1.0$

1000

20 $\mathrm{mm}$

$\mathrm{GPa}$

$\mathrm{GPa}$

$\%$

$\mathrm{g} / \mathrm{cm}^{3}$

$\mathrm{ppm} /{ }^{\circ} \mathrm{C}$

$\mathrm{mW}-\mathrm{cm}$

W/m-K

Other Properties

BET Surface Area

76.7799

Langmuir Surface Area

$\mathrm{m}^{2} / \mathrm{gram}$

$\mathrm{m}^{2}$ /gram 


\section{PROPERTIES Of RETICULATED VITREOUS CARBON}

Property

Relative Density

Bulk Density

Ligament Density

Ligament Resistivity

Crushing Strength (@70 $\mathrm{F}$ )

Melting Point (sublimes)

Thermal Expansion Coefficient

$$
\begin{aligned}
& 30-200^{\circ} \mathrm{F} \\
& 200-1800^{\circ} \mathrm{F}
\end{aligned}
$$

$\underline{\text { Value }}$

3

3.1

93

50

10 to 50

6330

1.2

1.8
Units

$\%$

$\mathrm{lbs} / \mathrm{ft}^{3}$

$\mathrm{lbs} / \mathrm{ft}^{3}$

$10^{-4} \mathrm{ohm} \mathrm{cm}$

Ibs/in ${ }^{2}$

${ }^{\circ} \mathrm{F}$

$\mathrm{ppm} /{ }^{\circ} \mathbf{F}$

$\mathrm{ppm} /{ }^{\circ} \mathrm{F}$

Temperature limitation is $600^{\circ} \mathrm{F}$ in air and $6330^{\circ} \mathrm{F}$ in non-oxidizing atmosphere.

Other Properties

100 ppi RVC Sample

BET Surface Area

Langmuir Surface Area

0.0923

$\mathrm{m}^{2} /$ gram

$\mathrm{m}^{2}$ /gram

80 ppi RVC Sample

BET Surface Area

Langmuir Surface Area

44.7955

$\mathrm{m}^{2} /$ gram

$\mathrm{m}^{2}$ /gram 


\title{
PROPERTIES of CARBON NANO-FIBERS
}

\author{
\#1094-A
}

Properties

BET Surface Area

Langmuir Surface Area $\underline{\text { Value }}$

115.1324

186.7804
Units

$\mathrm{m}^{2} / \mathrm{gram}$

$\mathrm{m}^{2} /$ gram

\#1094-B

Properties

BET Surface Area

Langmuir Surface Area
Value

182.7651

286.0305
Units

$\mathrm{m}^{2} /$ gram

$\mathrm{m}^{2} / \mathrm{gram}$ 
Table V

\section{PROPERTIES OF CARBON NANO-FIBERS GROWN ON GRAPHITE FIBER MATS}

\# 0295-A

Properties

BET Surface Area

Langmuir Surface Area $\underline{\text { Value }}$

99.9246

-
Units

$\mathrm{m}^{2} / \mathrm{gram}$

$\mathrm{m}^{2}$ /gram 


\section{"ENVIRONMENTAL POLLUTION CONTROL DEVICES BASED ON NOVEL FORMS OF CARBON"}

\section{PERCENTAGE of PROJECT COMPLETION}

\begin{tabular}{|c|c|}
\hline $\begin{array}{c}\text { TASK } \\
\quad \# \\
\end{array}$ & $\frac{\text { WBS }}{\underline{C O D E}}$ \\
\hline 1 & 1.0 \\
\hline 2 & 1.1 \\
\hline 3 & 1.2 \\
\hline 4 & 2.0 \\
\hline 5 & 3.0 \\
\hline 6 & 3.1 \\
\hline 7 & 3.2 \\
\hline 8 & 3.3 \\
\hline 9 & 3.4 \\
\hline 10 & 3.5 \\
\hline 11 & 4.0 \\
\hline 12 & 4.1 \\
\hline 13 & 4.2 \\
\hline 14 & 4.3 \\
\hline 15 & 4.4 \\
\hline 16 & 4.5 \\
\hline 17 & 4.6 \\
\hline 18 & 4.7 \\
\hline 19 & 5.0 \\
\hline 20 & 5.1 \\
\hline 21 & 5.2 \\
\hline 22 & 6.0 \\
\hline 23 & 7.0 \\
\hline
\end{tabular}

TASK NAME

PRELIMINARY RESEARCH

Electrochemical Remediation (ECR)

Technical Evaluation

ANALYTICAL TECHNIQUES

PREPARATION FOR TRIALS

Hire Post-Doctoral

Purchase Electrochemical System

Obtain Chemicals and Reagents

Obtain Carbon Samples (A-?)

Characterize Carbon Samples

TESTING

ECR - Sample A: Nano-Fibers (1094A)

ECR - Sample B: Nano-Fibers (1094B)

ECR - Sample C: RVC (100 ppi)

ECR - Sample D: RVC (80 ppi)

ECR - Sample E: PYRIGRAF III (LOT ADNH)

ECR - Sample F - ?

Trial Repeats (Concurrent)

ANALYSIS and REPORTING

Analysis and Data Reduction

Reports and Manuscripts

CLOSURE

OVERALL WORK COMPLETE
DUR

OCT-DEC

NOV-DEC

OCT-JUN

SEP-OCT

SEP-NOV

OCT-NOV

OCT-DEC

OCT-FEB

NOV-JUN

NOV-JUN

NOV-JUN

NOV-JUN

NOV-JUN

NOV-JUN

MAR-JUN

JUN-JUL

OCT-JUL

JUL

AUG

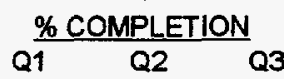

Q3

$\begin{array}{rrr}75 \% & 90 \% & 94 \% \\ 50 \% & 60 \% & 70 \% \\ 25 \% & 50 \% & 70 \% \\ 100 \% & 100 \% & 100 \% \\ 25 \% & 60 \% & 75 \% \\ 90 \% & 90 \% & 90 \% \\ 10 \% & 25 \% & 40 \% \\ 5 \% & 10 \% & 25 \% \\ 0 \% & 15 \% & 70 \% \\ 0 \% & 5 \% & 50 \% \\ 0 \% & 15 \% & 70 \% \\ 0 \% & 10 \% & 10 \% \\ 0 \% & 10 \% & 10 \% \\ 0 \% & 0 \% & 0 \% \\ 0 \% & 5 \% & 20 \% \\ 0 \% & 5 \% & 40 \% \\ 25 \% & 50 \% & 75 \%\end{array}$




\section{REFERENCES}

1. Wang, J. "Stripping Analysis: Principles, Instrumentation, and Application"; VCH Publishers: Deerfield Beach, FL, 1985.

2. Gaylor, V. F.; Elving, P.J.; Conrad, A. L. Anal. Chem., 1953, 25, 1078.

3. Morris, J. B.; Schempf, J. M. Anal. Chem., 1959, 31, 286.

4. Adams, R. N. Anal. Chem., 1958, 30, 1576.

5. Yamado, S.; Sato, H. Nature, 1962, 193, 261.

6. Blaedel, W. J.; Wang, J. Anal. Chem., 1980, 52, 1697.

7. Dryhurst, G.; McAllister, D. L. in "Laboratory Techniques in Electroanalytical Chemistry", Kissinger, P. T. and Heinenman, W. R., Eds.; Marcel Dekker, Inc.: New York, NY, 1984; Chapter 10.

8. Bennion, D. N.; Newman, J. J. Appl. Electrochem., 1972, 2, 113.

9. Chu, A. K. P.; Fleischmann, M.; Hills, G. J. J. Appl. Electrochem., 1974, 4, 323.

10. Fujinaga, T.; Kihara, S. Crit. Rev. Anal. Chem., 1977, 6, 223.

11. Blaedel, W. J.; Strohl, J. H. Anal. Chem., 1964, 36, 1245.

12. Yaniv, D.; Ariel, M. J. Electroanal. Chem. Interfacial Electrochem., 1977, 79, 159.

13. Suzkover, E. Ph.D. Dissertation, Technion-I.I.T., Haifa, 1977.

14. Wang, J.; Dewald, H. D. J. Electrochem. Soc., 1983, 130(9), 1814.

15. Baker, R. T. K., Rodriguez, N.M. U.S. Patent 5,149,584.

16. Rodriguez, N.M., Baker, R.T.K. Patent Application filed October 1992.

17. Applied Sciences, Inc. Technical data sheet on Advanced Material Development.

18. Wang, J. Electrochim. Acta., 1981, 26, 1721.

19. Reticulated Vitreous Carbon (An Exciting New Material), Energy Research and Generation, Inc., Oakland, CA

20. Cowlard, F.C., Lewis, J. C. J. of Materials Sciences, 1967, 2, 507.

21. Noda, T., Inagaki, M., Yamada, S. J. of Non-Crystalline Solids, 1969, $1,285$.

22. Lewis, J. C., Murdoch, R., Moul, A. N. Nature, 1969, vol 221,1137.

23. Kawamura, K., Ryan, T., Jenkins, G. "The Incorporation of Glassy Carbons in Metals," Paper presented at 9th Carbon Conference.

24. Tamaguchi, T. Carbon, 1963, 1, 47. 


\section{0 \\ INFORMATION SYSTEMS, PUBLIC POLICY, COMMUNITY OUTREACH, AND ECONOMICS}




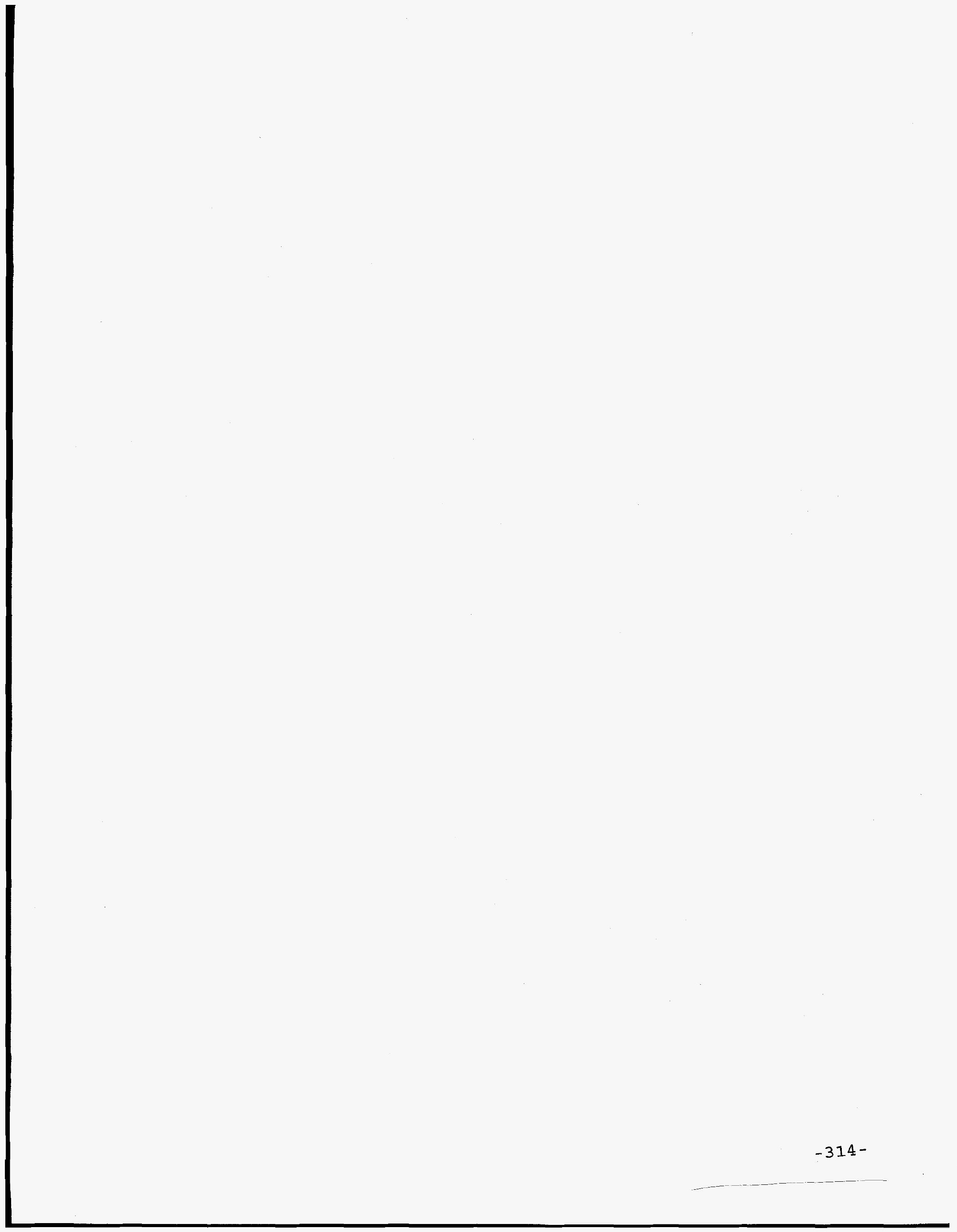

$-314-$

$-314$

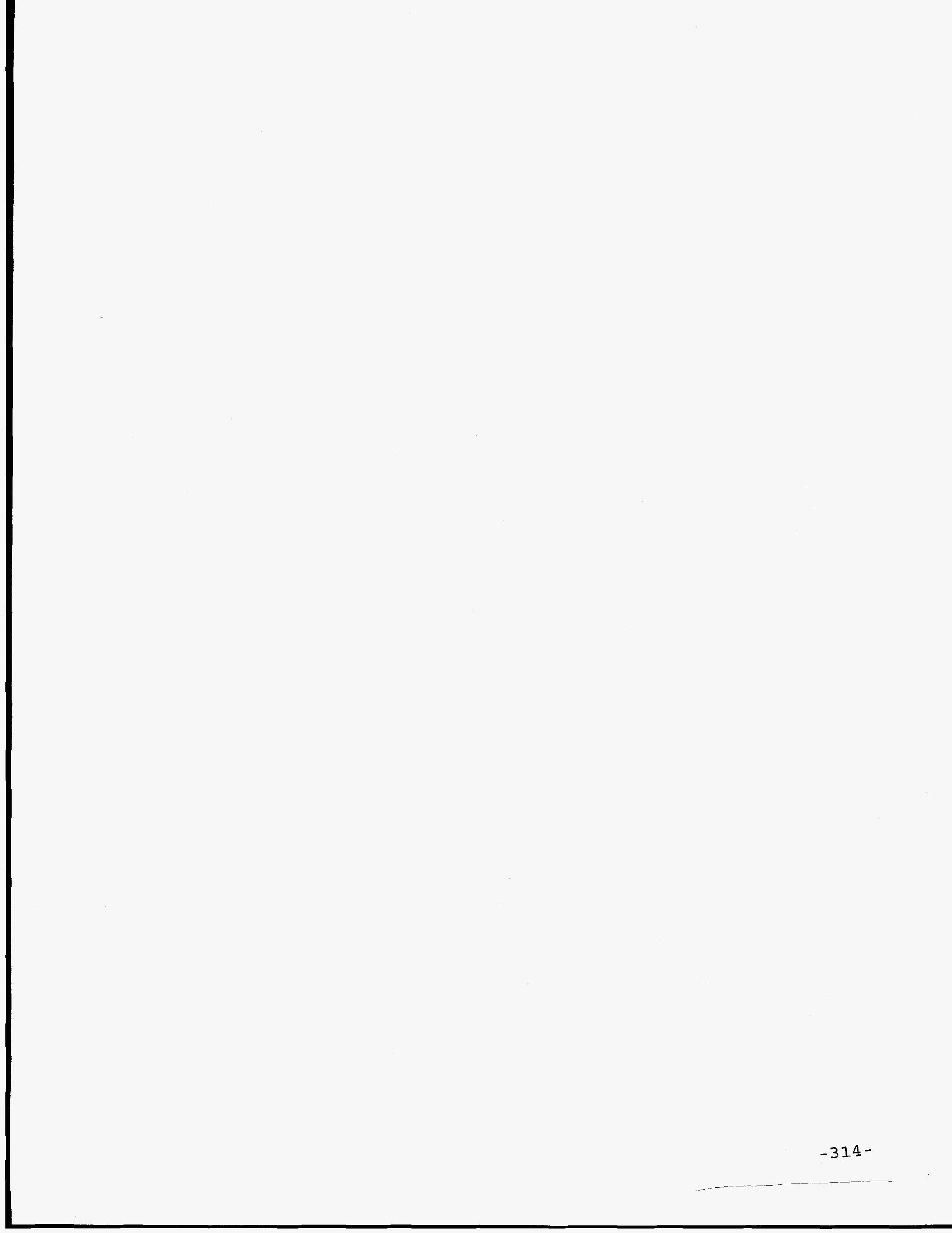




\title{
WINFIELD LOCK AND DAM REMEDIATION
}

\author{
METC TASK \# 3.1 \\ Quarterly Technical Progress Report \\ for Period January 1 through March 31, 1994 \\ Work Performed Under \\ Contract No.: DE-FC21-92MC29467 \\ For \\ U.S. Department of Energy \\ Office of Fossil Energy \\ Morgantown Energy Technology Center \\ P. O. Box 880, Collins Ferry Road \\ Morgantown, West Virginia
}

By

Raymond J. Lovett

National Research Center for Coal and Energy

Environmental Technology Division

West Virginia University

Morgantown, West Virginia 26506

April 1995 
$-316-$ 


\section{Abstract}

The United States Army Corps of Engineers (ACE) must remediate a contaminated industrial site, formerly owned by ACF Industries, Inc., in order to build a new lock on the Kanawha River at Winfield, WV. The original remediation plan, to incinerate the contaminated soil, generated much controversy in the surrounding communities, notably Eleanor, WV.

West Virginia University became involved in the project in August of 1992. Shortly after that time, a formal program to involve WVU in the solution to the remediation problem began. The WVU involvement has been two-pronged. WVU has interacted extensively with the citizens of Eleanor (and Putnam County) providing technical, logistical and financial assistance in their efforts to understand and evaluate the ACE plans for remediation. A primary objective for WVU is to inform the citizens of possible health and safety problems with proposed operations.

These investigations are being conducted by the National Research Center for Coal and Energy (NRCCE) staff and WVU faculty. 
$-318-$ 


\section{Table of Contents}

EXECUTIVE SUMMARY

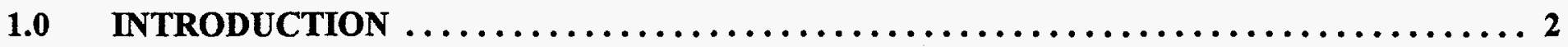

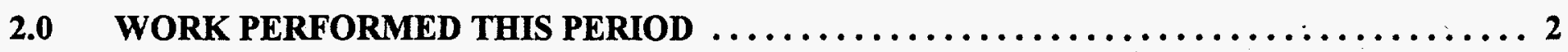

3.0 WORK PLANNED FOR NEXT PERIOD $\ldots \ldots \ldots \ldots \ldots \ldots \ldots \ldots \ldots \ldots \ldots \ldots \ldots \ldots, \ldots$

4.0 TECHNICAL/ADMINISTRATIVE DIFFICULTIES $\ldots \ldots \ldots \ldots \ldots \ldots \ldots \ldots \ldots \ldots \ldots$

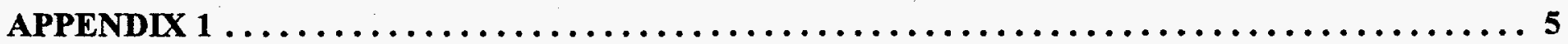
AIR MONITORING PROPOSAL 3 
$-320-$ 


\section{EXECUTIVE SUMMARY}

The Lock and Dam contamination will probably be excavated and shipped to Utah. Plans and specifications will be established in the next three months. Excavation will probably begin in July. Questions remain concerning an agreeable air monitoring plan. 
$-322-$ 
The site of the former ACF Industries, Inc. railroad tank car maintenance shop is contaminated by various organic and inorganic chemicals. The company abandoned the site in March 1986 and the U.S. Army Corps of Engineers (ACE) acquired the site, which was needed for the approach to expansion of the Winfield Locks and Dam. The extent of contamination, and most explicitly, the presence of dioxin at the site, had been inadequately documented before the ACE took possession of the land. The ACE, when it became aware of the extent of contamination, undertook a study which culminated in the publication of an Engineering Evaluation and Cost Analysis (EE/CA) in May 1992. The EE/CA was made public with a 30 day response period. The net conclusion of the EE/CA was that the ACE would incinerate the contaminated soil. The combination of citizen perception that they had not been appropriately informed of the problem and the proposal to incinerate the soil led to a concerted effort by the citizens to have the EE/CA reconsidered. The concerted effort, which included the involvement of the WV Congressional delegation, successfully led to reconsideration of the issue by the Army.

The subsequent reevaluation by the Army took nearly 7 months; the results, an Action Memorandum for the site, was released in December 1992. The Action Memorandum proposed that the soil be excavated, stored in temporary buildings, then remediated after further study.

As a result of the public involvement in the lock issue, Senator Robert C. Byrd of West Virginia and the Senate appropriations committee published some language which involved the Department of Energy and West Virginia University in the problem. The role of the DOE was to assist WVU financially in their efforts to safeguard the health and safety of the citizens and investigate the application of DOE technology in remediation of the site. The DOE-WVU effort is, thus, funded by this Cooperative Agreement and consists of direct assistance to the area around the site as well as certain technological investigations directed towards the choice of the eventual remediation technology (or technologies).

\subsection{WORK PERFORMED THIS PERIOD}

The air monitoring proposal (appended) was sent to the Umbrella Committee for forwarding to ACF. The proposal has been cut back, only mass spectrometric methods for real-time (or nearly so) volatiles monitoring and real-time dust monitoring are proposed (Appendix 1). The intention is to have ACF fund the study. The citizens at Winfield and the Corps were supportive.

ACF (the PRP) proposed last spring to ship the contaminated soil. The Corps and ACF have agreed in principle to do this and are finalizing the paperwork. The details of the planned excavation and shipping will be available this quarter.

Fred Youngs prepared a document critical of the air monitoring program that the Corps had proposed. The adequacy of the program to protect public health appears to be the key issue between the parties .

\section{MEETINGS}

Winfield Umbrella Committee Meeting of 21 February 1995

The meeting was held at the Eleanor Town Hall at 7:00 P.M. Present were the Committee, Corps of Engineers representatives, Susan Small from Rep. Wise's office, Dr. Sentelle (sp?), the Putnam County School 
The Umbrella Committee had asked me to provide a revised copy of the Real-Time Air Monitoring proposal, which I had originally written for DOE funding. The intention is to pursue funding from ACF (or the Corps) for some real time monitoring. Of particular interest is the MS/MS unit being developed by Fred King in conjunction with Varian Corporation. I had intended to be in Las Vegas that week at a meeting concerning On-Site Monitoring Instrumentation, but the rescheduling of the Umbrella Meeting and the lack of any Cooperative Agreement funds for 1995 caused me to cancel. The Committee was interested in my report on the Las Vegas meeting and disappointed I could not attend.

The Corps arrived and announced that they have agreed in principle to having ACF excavate the site and ship the soil by rail to landfills in Utah. The two parties have prepared a consent decree, which must be ratified. The Corps and ACF are formulating the plans for the remediation, which the Corps will approve when satisfied. Once satisfied, the Corps will sign the consent decree. At that time, a 30 day public comment period will begin (advertised in the Federal Register). The comments will be addressed, perhaps some changes made, then the consent decree will be blessed by a Federal judge. The Corps hopes all of this will be finished by April 1 .

Some details of the excavation (sampling, split samples, etc.) were discussed. Some March sampling by ACF is planned to help define the work areas. ACF predicts the excavation will take 6-7 months. The Corps does not believe that excavation can begin before July 1 , so the most optimistic estimate of complete remediation is by January 1, 1996. The excavation/remediation will be conducted by USPCI, which has just been bought by Laidlaw. USPCI used to be owned by the Union Pacific Railroad, which also owns ACF. The question of enforcement was raised. The Corps stated that the Colonel has enforcement responsibilities, but that enforcement would be connected to the original agreement. The Corps will oversee all aspects of the clean-up, although ACF will pay for it. The Corps will conduct duplicate analyses to verify that remaining soil is in fact clean and need not be shipped. Current estimates are that the original 60,000 cubic yards will be moved.

\section{Winfield Umbrella Committee Meeting of 14 March 1995}

The meeting was held at the Eleanor Town Hall at 7:00 P.M. Present were the Committee, Susan Small from Rep. Wise's office and me.

The meeting was quite short. Two major topics were discussed, the real-time air monitoring program using the Fred King MS/MS units and the $\$ 100,000$ consultant funds in the possession of the Corps.

It was decided to allow ACF the opportunity to fund the air monitoring study; the proposal and budgets were to be forwarded to them. The letter to ACF would be copied to the State's congressional delegation. If ACF did not respond favorably, the request would be forwarded to the Corps.

The $\$ 100,000$ continued to cause concern. The intent of the original legislation was not properly expressed in the language, thus certain FARs are limiting the Umbrella Committee's freedom of choice. The RFP had been on the street, but was cancelled at the Umbrella Group's request in order to establish the exact level of citizen participation in the process. It was decided to set up a meeting with Col. Jemiola of the Huntington Corps to discuss the issue. 


\section{Meeting with Col. Jemiola at Huntington Corps Offices 27 March 1995}

This meeting consisted of Col. Jemiola, Dwight Smith and a procurement specialist from the Corps, Tim McCoy (President of the Umbrella Group), Susan Small (Congressman Wise's staff) and me. The meeting was held starting at 2:00 P.M. at the Corps of Engineers office in Huntington. The gist of the meeting is that the Corps will work with the citizens to establish the greatest citizen involvement possible within the legal framework of FARs.

\section{Current Situation}

The storage buildings are under construction. The citizens are gathering their evidence to attempt to have the Corps expand the air monitoring at the site. Some study is being conducted at the site to better delineate the contaminated areas. The site excavation plans and an amended EECA are being prepared.

\subsection{WORK PLANNED FOR NEXT PERIOD}

Major emphasis will be placed next quarter on the final development of the mass spectrometer unit. The unit must be operable by about June 15 if it is to have utility during the excavation. More than likely a trip to Varian will be scheduled in May. Effort will be expended to resolve the conflict on the air monitoring program and the consent decree and workplan will be evaluated.

\subsection{TECHNICAL/ADMINISTRATIVE DIFFICULTIES}

No travel could be performed during the period when there was no funding (Jan. 1-March 10). The lack of funds inhibited progress. 


\section{APPENDIX 1}

\section{DRAFT PROPOSAL}

Project Title: Real Time Air Monitoring at the Winfield Lock and Dam Remediation Site

Principal Investigator: Raymond J. Lovett, Environmental Technology Center, NRCCE, West Virginia University

Date: 7 April 1995 


\section{Introduction}

Sites contaminated with hazardous waste can release toxic materials to site workers and the surrounding communities. These toxic materials can be released in the absence of human intervention, such as a leaking drum, or due to remediation activities, such as excavation. The most potentially harmful release route is through the air. In order to preserve and protect the health and safety of persons within close proximity to such sites, air monitoring systems are often prescribed.

Air monitoring systems typically are composed of time averaged sampling followed by laboratory analysis. Such systems can average over a work day or for longer periods of time. Regardless of the period, the sampling device is collected, sent to a laboratory and results of the air monitoring are not known for days or weeks. Typical monitoring devices include particle collectors, for PM-10 and total particulate analyses, and Summa canisters and polyurethane foam collectors for volatile and semivolatile organic compounds.

The weakness of time averaged monitoring is the inability of these methods to provide time dependent evaluations of fugitive emissions. The response of an individual at a site to a $1 \mathrm{ppm}$ release over 480 minutes $(8$ hours) and a one minute release of $480 \mathrm{ppm}$ will differ substantially (Ducatman (personal communication), 1994). Since these short lived singular events have traditionally been difficult to monitor, risk analyses and regulatory air monitoring requirements have focussed on time averaged emissions. Recently developed schemes for more closely spaced measurements, nominally real time monitoring, have not been extensively tested at remediation sites. Additionally, these newer methods do not yet have quality assurance procedures equivalent to laboratory based evaluations of toxic chemical concentrations. The new methodologies, do, however, have the capacity to differentiate short term high risk toxic emissions from long term low concentration emissions. Such information is of vital interest to remediation workers and near proximity citizens.

A relatively small number of real time instruments have been developed. The ability to determine real time concentrations of environmental pollutants requires a very sensitive measuring device.

Mass spectrometer (MS) systems have traditionally been interfaced with gas chromatographs (GC). These GC/MS systems are used for the laboratory analysis of, e.g., the polyurethane foam units in air samplers. The GC functions as an analyte separation device and the MS identifies and quantifies the analytes. Unfortunately, GC/MS is generally slow (minutes to hours) and the GC capacity is so small that limits of detection on real time samples (unconcentrated) are high. Older GC/MS units were based on quadrupole technology, but more modern units are ion traps, which have 10 to 1000 times more sensitivity. Field GC/MS units with ion traps would be more sensitive and more likely to detect low levels of contaminants than quadrupole units.

A recent commercial advance in mass spectrometry is the MS/MS ion trap. This unit can perform separations and quantification without a GC. The unit performs an initial ionization, creating a parent ion, which is then isolated using the radiofrequency field of the ion trap. The isolated parent ion is then further ionized to give fragments that identify the species. A full range of target analytes can be sequentially created, trapped and analyzed in seconds or minutes. Better detection limits can be achieved by concentrating parent ions with longer sampling times. Ions can be accumulated until the trap is full. A high sensitivity, multispecies analysis would take minutes. 


\section{Proposal}

We propose to use an atmospheric sampling MS/MS and real time particle analyzers to monitor the air at the Winfield Lock and Dam site during the excavation of the contaminated area. These units would be used in addition to conventional air monitoring equipment.

The mass spectrometer unit will be moved around the site. It will be used with the summa canisters and PUF units to provide cross correlation of the field unit with the time averaging unit. The MS unit will also be used during the organic pocket excavation to determine its usefulness.

Continuous particle monitors can be mounted on the time averaged particluate samplers or operated separately. Two general sorts are available, a triboelectric total particle mass monitor and optical (laser) based size differentiating methods. The availability of real time particle monitoring would allow high volume incidents to be isolated from baseline dust generation over the sampling period. The time dependent results would allow correlation of the dust generation to meteorological and excavation operations. Units set in the area between the hazardous excavation area and the non-hazardous excavation area can differentiate between hazardous dust and non-hazardous dust emission, since wind direction and operations information will be available on a real time basis.

The MS unit will be tested in the laboratories at West Virginia University to provide limits of detection, calibration and reproducibility data prior to the field tests. New standardization methodology will be initiated to evaluate field standardization capabilities. For example, a known amount of non-hazardous chemical can be released across the beam at preselected times. The quantitative MS response will be easier to verify by using the 24 hour samplers employed at the site.

Once standardization and method development are completed in the lab, the results will be made available to the responsible parties for a final determination of the suitability of the methods for field implementation at the site. If the system performance is acceptable, a full implementation schedule will be provided based on planned site activities. At minimum, pre-excavation testing and as nearly continuous use as possible during site activities are desired in order to provide an adequate effort to monitor real time exposures of the local residents.

All data will be available to the excavating agency and the citizens of the area through the Winfield Umbrella Group. The results will be written up into a final report on the success of each method.

\section{Justification}

\section{Mass Spectrometer System}

A few research projects are underway to develop mass spectrometric methods for routine monitoring. A sample of on-going work is that of Los Alamos, which has used GC/MS and a sampling system called CMAS along with membrane introduction. The unit proposed here uses an MS/MS system which alleviates the need for GC and can preconcentrate the ions to lower the limit of detection from the air. The Los Alamos unit states that detection limits in air are in the low parts per billion by volume. The predicted air concentration at Winfield during excavation is about a part per trillion $\left(\mathrm{ug} / \mathrm{m}^{3}\right)($ Dames and Moore, 1994). Use of the MS/MS should improve the absolute detection, but we are not aligned with Los Alamos to use their sampling unit, which preconcentrates the organics. The actual limits of detection for the WVU MS/MS unit are as yet unknown.

The ppb limits of detection would provide useful information during excavation of the volatile organics areas and for monitoring the drying areas. The unit would provide species specific, nearly real time estimates of the air 
concentration of volatiles. The objective would be to provide ppt limits of detection with species specific analysis. Whether the MS/MS system can provide that level of detection is as yet unknown. The absolute LODs are in the range of a picogram; a ppt is a $\mathrm{pg} / \mathrm{cm}^{3}$, thus if one $\mathrm{cm}^{3}$ of air can be sampled at $100 \%$ efficiency, the ppt goal could be reached.

\section{Dust Monitors}

these units would be able to provide real time differentiation of dust events during the remediation. If the rail cars are loaded in the buildings, dust emission from the building could be measured. With appropriate design, off-site dust release of the non-hazardous areas could be differentiated from on-site releases.

\section{Work plan}

This project would start as early as soon as funded.

1. Develop instrument: The MS/MS is already available. The system is being modified by Profeesor Fred King of the WVU Chemistry Department under a grant from the Department of Energy. Modification will be in cooperation with Varian Instruments of Palo Alto, $\mathrm{CA}$, the unit manufacturer. Dr. King's deliverable is an air sampling MS/MS unit, but he is not being funded to adapt it to full field capability, which is needed for implementation. Certain pieces, notably some sampling hardware, may be needed to complete the unit. If necessary, cooperation with Los Alamos and/or Oak Ridge will be initiated to facilitate sample introduction development. All safety training would be initiated as soon as approval is given.

2. Develop QAVQC Plan: This is essentially a detailed description of the field monitoring experiment and all supporting data which will determine whether the tests are a success. Included will be details of calibration, check samples, confirmatory field sampling, etc.

3. The site safety plan will be develop in conjunction with contractor efforts. The WVU safety plan will conform to Corps of Engineers and USEPA requirements.

4. Train personnel: This training comprises both safety and instrument training.

5. Test Mass Spectrometer: Lab testing will occur at the NRCCE building. Field testing will be conducted at gasoline stations and possibly during a remediation technology test in California.

6. Write Interim Report: This report will detail the performance of the instruments including the limits of detection and operational requirements and cost.

\section{FUNDING DECISION POINT}

7. Write Site implementation plan: This plan will incorporate the performance data and detail installation at the site and operational plans. Included will be times of measurement, correlations to work efforts and reporting requirements. Demobilization plan will also be included. 
8. Install equipment: The equipment will be installed when the implementation plan is approved. Operation of the equipment will follow the implementation plan.

9. Remove equipment: The MS/MS equipment will be removed after decontamination back to West Virginia University.

10. Write final report: This final report will be presented to the financial support agency and Winfield Umbrella Group. The report will detail the success with which the equipment protected the health and safety of the citizens during the removal actions. 


\title{
A GIS-BASED INFRASTRUCTURE
}

\author{
FOR SITE CHARACTERIZATION AND REMEDIATION \\ METC Task No. MC28-95MU \\ METC TASK \# 3.2
}

Quarterly Technical Progress Report

Reporting Period:

January 1 - March 31, 1995

Work Performed Under Contract

No.: DE-FC21-92MC29467

For:

U.S. Department of Energy

Office of Fossil Energy

Morgantown Energy Technology Center

Morgantown, West Virginia

\author{
By: \\ Marshall University \\ Center for Environmental, Geotechnical, and Applied Sciences \\ Huntington, West Virginia 25755 \\ (304) 696-5453 \\ (304) 696-5454 Fax
}


$-332-$ 


\begin{abstract}
The primary goal of this proposed work is to determine an effective GIS-based infrastructure for describing, characterizing, and remediating contaminated sites. The work is being carried out using the remediation needs of the U.S. Army Corps of Engineers Huntington, WV district office as a basis--giving the benefit of real needs of on-going remediation projects. The work includes devising and specifying an integrated system with features targeted to site remediation/restoration needs, establishing operational procedures for effective use of the integrated system, and establishing methods for effective technology transfer. The effort will also result in the establishment of a professional team at Marshall University with capability and availability to provide supporting services in the application of GIS-based tools and methods in site restoration efforts.
\end{abstract}




$$
-334-
$$




\section{EXECUTIVE SUMMARY}

This document constitutes the required Quarterly Report for the first quarter of 1995, for Task No. MC28-95MU under the DOE/METC/WVU Cooperative Agreement, contract no. DE-FC21-92MC29467. It documents technical accomplishments and projections, and also provides cost status and projections as of March $31,1995$.

Despite a late award announcement (March 10, 1995), we made very good progress during this quarter, which puts us in an excellent position to successfully complete all tasks during the calendar year. Of five tasks, only one (requirements determination) has been delayed, and we expect to fully overcome this delay during the second quarter. We will also increase our expenditures during the second quarter, including hardware and software acquisitions, so that about half the funds will be spent by mid-year.

We have established a very productive working relationship with personnel of the Corps Huntington district office, and anticipate a very fruitful collaborative effort as we undertake experimental evaluation of candidate hardware and software.

In summary, we are in an excellent position to successfully complete all tasks during this calendar year, and thus to achieve the overall goal of determining an effective GIS-based infrastructure for describing, characterizing, and remediating contaminated sites. 
$-336-$ 


\section{TABLE OF CONTENTS}

DISCLAIMER

ABSTRACT

EXECUTIVE SUMMARY

iv

1.0 INTRODUCTION

2.0 PURPOSE

3.0 BACKGROUND

4.0 METHODOLOGY

5.0 WORK PERFORMED THIS PERIOD

4

5.1 Activities

4

5.2 Schedule and Costs

6.0 RESULTS AND DISCUSSION (CURRENT PERIOD)

7.0 CONCLUSIONS (CURRENT PERIOD)

8.0 WORK PLANNED FOR NEXT PERIOD

9.0 TECHNICAL/ADMINISTRATIVE DIFFICULTIES

APPENDICES 10

A. REFERENCES 10

B. LIST OF ACRONYMS AND ABBREVIATIONS 10 



\subsection{INTRODUCTION}

This effort focuses on determining GIS-based capabilities for site characterization and remediation. This is a pressing need, largely unsatisfied at the current time. Although there are numerous available GIS systems, and many different software components that could be useful in site characterization and remediation, there is no available system that brings together the numerous needed capabilities. The approach is to base a needs assessment for such a GIS-based system on the on-going work of the Huntington Corps district office. This will provide a realistic needs determination: the Huntington Corps office is faced with an immediate need for effective GIS-based software tools to more effectively manage site remediation in the district. Further, a working relationship has already been established between the Marshall University team and personnel within the Corps office. The U.S. Department of Energy (DOE) Morgantown Energy Technology Center (METC), and other agencies, stand to benefit from the results of this work, since it will be grounded in real needs of real, ongoing remediation projects.

\subsection{PURPOSE}

The primary goal of this work is to determine an effective GIS-based infrastructure for describing, characterizing, and remediating contaminated sites. Objectives involved in achieving this goal include:

(a) devising and specifying an integrated system whose features are targeted to specific needs for site remediation/restoration--including a set of GIS-based software tools and supporting computer hardware,

(b) establishing operational procedures for effective application of the system,

(c) establishing methods for effective transfer of technology (system, procedures) to a user organization (USACE Huntington District office, in the first instance), and

(d) simultaneously establishing a professional team at Marshall University with the capability and availability to provide supporting services and consultation in the application of GIS-related tools in site restoration efforts.

\subsection{BACKGROUND}

Greographic Information Systems (GISs) are increasing rapidly in numbers and areas of application. No doubt the expansion is influenced strongly by the growing national interest in environmental protection and restoration. Numerous GIS systems are available--including commercial (e.g., ARCINFO, Intergraph MGE, MapInfo), government-sponsored (GRASS), and university research based (IDRISI, ICASE/GRACE). The desired applicability of GISs is extremely broad (e.g., air quality monitoring, groundwater contamination, areas in a city accessible by public transport). Thus the GIS systems must be very generic in their capabilities. This genericness is attractive in providing versatility of application breadth, but of necessity limits the depth of features for a given application area.

The nation faces a massive problem relative to contaminated sites. The U.S. Department of Energy, the U.S. Army Corps of Engineers, and many other government agencies are faced with requirements to remediate contaminated sites under their purview. The Huntington District of the U.S. Army Corps of Engineers (USACE) has undertaken to assemble computer-based tools to help them in describing, characterizing, and remediating contaminated sites. They have obtained the Integrated Computer Assisted Site Evaluator / Graphical Remedial Assessment and Cost Evaluation (ICASE/GRACE) system, developed at the University of Cincinnati, for evaluation. They have also obtained and installed Intergraph's MGE system, and anticipate obtaining Intergraph's ERMA (for Environmental Resource Management Application) system, intended to support site 
assessment, modeling and remediation. Under a previous METC task, Marshall University evaluated ICASE/GRACE for use by the Huntington USACE District.

\subsection{METHODOLOGY}

Following are descriptions of the tasks to be conducted, and associated schedules.

Task 1: Information Required for the National Environmental Policy Act

To be supplied within 60 days after contract award.

Task 2: Determine System Requirements

Interview USACE Huntington District office personnel involved with remediation projects, assess needs as they perceive them for describing, characterizing, and remediating contaminated sites. Consider approaches of other organizations with remediation requirements, including other USACE offices, and other Department of Energy-funded work. From this input, determine and specify system requirements necessary to fulfill the identified needs.

Schedule: January 1 through March 31, 1995.

Task 3: Devise and Specify an Integrated System

Undertake to determine and specify a system that satisfies the requirements identified in Task 2. Note that the outcome of this task will be a specification of a recommended system, and not an implementation as such.

Determine a GIS system to serve as the basis for the overall system--evaluating candidate GIS systems based on their inherent suitability for the role, as well as their current importance to organizations with whom data interchange may be necessary. We will emphasize commercially-available systems and governmentsponsored systems to the maximum extent feasible. One GIS system we will evaluate is Intergraph's MGE system, Windows NT version, due to the fact that the USACE Nashville District office uses this MGE version, and the Huntington office must be able to interchange data with the Nashville office.

Determine a means to integrate other needed software and data sources-currently existing and anticipated--into an overall system based on an identified GIS system, with the overall system having a uniform "look and feel". Examples of other needs are a cost modeling tool in current USACE use, Modflow software, and various features of ICASE/GRACE. Means to integrate other components into a GIS system could include data translation software utilities and windows-based dialog boxes, for example. The means will be provided to augment the software complement with additional capabilities in the future.

The most desirable outcome would be that carefully-selected software can be integrated, without modification or additional software development, into a system that fully satisfies all identified requirements. In the event that is not a feasible outcome, we will determine and recommend approaches for meeting the un-met requirements.

A necessary, and interwoven, aspect of this task is to ensure that the software system being devised can be accommodated by an acceptable range of computing hardware; i.e., by both lap-top PCs and high-end Pentium PCs, and even by Unix-based workstations if that is found to be a requirement.

It may be that multiple feasible approaches will be identified to accomplish some aspects of the required system. If so, we will document the options, and give trade-off considerations for making choices.

Schedule: January 1 through November 30, 1995. 
Task 4: Determine Operating Procedures

Determine and describe effective procedures for using the system. This will include guidance concerning combinations--and sequences--of software tools to use for certain classes of applications, set-up assumptions for each tool, and inter-tool control and data management.

Representative scenarios will be devised and documented.

If it is found to be necessary to modify some software or to develop some additional software to achieve all requirements, we will nonetheless summarize procedures involving the system features expected to be available after modification and/or development, so that a comprehensive understanding of the full resulting system can be gained, and also to offer perspective and guidance in developing and providing any additional features.

Schedule: October 1 through November 30, 1995.

Task 5: Develop Materials for Technology Transfer

Establish means for effective transfer of technology--the integrated system and operating procedures--to a user organization. The USACE Huntington District office will be the initial user organization, in concept, since we will be basing much of our requirements determination efforts on their needs. However, our efforts in technology transfer will be guided by the need for various user organizations to be accommodated.

Emphasis will be placed on development of tutorial materials, including on-line materials, and on development of seminar presentation materials to provide an overview of the tools and procedures. Full documentation of system requirements, system specification, and operating procedures will, of course, be provided as well.

Schedule: November 1 through December 31, 1995.

\section{Deliverables:}

Deliverables from this work will be:

- A written statement of requirements for software and hardware necessary to conduct site description and characterization, and assess remediation strategies--based on detailed analysis of needs of the Huntington Corps office, with participation and cooperation of their personnel

- Written descriptions of in-depth evaluations of various candidate software and hardware approaches for meeting the statement of requirements, with the relative merits of specific approaches, and rationale for each approach recommended

- A detailed description of a recommended system: hardware and software components--including use of available commercial or government software, strategies for integrating the components, and if necessary, details of a limited amount of software requiring development in order to achieve a satisfactory system

- Operating procedures for effective application of the system

- Educational/training tutorial materials to enable technology transfer for system capabilities and operating procedures

- Recommendations concerning strategies for undertaking system implementation based on the system description 


\subsection{WORK PERFORMED THIS PERIOD}

\subsection{Activities}

Notification of award of this task was received from the METC/WVU Cooperative Agreement Director (Dr. Cook) on March 10, 1995. Some of the effort described in this section had been conducted prior to that date, in anticipation of the award. The following summary is correlated to tasks.

Task 1: Information Required for the National Environmental Policy Act

This material has been prepared for transmittal during the first half of April.

\section{Task 2: Determine System Requirements}

During this period we undertook to determine system requirements, based especially on the needs of the Huntington District Office of the Corps of Engineers. Identification of specific needs has guided our efforts in selecting candidate software and hardware systems for evaluation. Evaluation of specific software and hardware has helped us refine identified needs, and move toward formulation of requirements.

In the following paragraphs we present a brief summary of our software/hardware evaluation efforts carried out during this period.

1. Evaluation of software:

a. Geographic Information Systems (GISs):

The three software packages that we considered were: ICASE/GRACE (evaluated under METC summer contract 1994--see Reference 1), ESRI's ARC/INFO, and Intergraph's MGE.

Jim Hooper and Akhtar Lodgher attended a forty-hour ARC/INFO workshop at the University of Vermont during February 13-17, 1995, to get a better understanding of the PC ARC/INFO system. PC ARC/INFO is a popular, generic GIS and has several components for processing and viewing data in different forms. However, the PC system is not suitable for handling large amounts of data; this would require the use of ARC/INFO on a Unix platform. Also, ARC/INFO, even for a Unix platform, does not have groundwater or 3-D modeling packages available (such as ERMA or Voxel for MGE). Such packages, if they were available, would have to be purchased from third party vendors.

Intergraph's MGE is a fully functional GIS which runs on a Windows NT platform. In terms of its functional capabilities, it evaluates much better than ARC/INFO for the needs identified. The Huntington District Corps of Engineers has made the decision to acquire Intergraph's MGE. Their decision strongly influences our choice, since we are committed to support them in their GIS work. We plan to purchase an educational copy of MGE in the next quarter, and attend Intergraph training on MGE.

\section{b. Database systems:}

The databases we are considering will have to operate under the Windows NT platform using a client-server architecture. The possible considerations are: Oracle, MS SQL Server, and Sybase SQL Server. The Corps uses Oracle (on the Unix platform) as their standard database for all projects. Oracle is in the process of introducing the Windows NT version of the software. Subsequently Intergraph will supply the necessary "hooks" to interact with Oracle. Currently MGE interacts with MS SQL Server and Sybase SQL Server, both of which already operate under the NT system. The underlying database--as long as it is an SQL database--is transparent to MGE. 
We are not at this time planning to use Oracle because Marshall University does not have a site license agreement for the system operating under NT, and this would make the use of Oracle very expensive. We are more inclined to the use of MS SQL Server because it can be acquired at relatively low cost, due to Microsoft's volume discount program with the university. Also, based on our review of evaluations of Oracle and MS SQL found in commercial literature, these two products compare equally on all functional and speed factors. The use of MS SQL will allow us to test MGE using a different database (as compared to the Corps), which will test the desirable "transparency" feature of MGE relative to the database.

c. Operating systems:

The operating systems considered were MS DOS, Windows NT and Unix. MS DOS-based systems are small and are not suited for development work of large systems. Packages that work under the Unix system require the use of workstations. Unix based workstations are generally not portable and are not easily usable for field sites. Windows NT provides the flexibility of installation on portable laptop computers, as well as the power to do development work. Also, the Integraph MGE system runs under Windows NT. Thus Windows NT is our current operating system of choice.

\section{d. Network software:}

The Windows NT networking component will be used for networking the machines. The machines will be connected physically by Ethernet cables.

\section{Evaluation of Hardware:}

The hardware under consideration is one main workstation to be used as the server, one development workstation to be used as the client, and one laptop system which can be used as the "field" computer.

a. The server workstation:

This machine would serve both as a server and as a workstation for development work. Requirements include at least $32 \mathrm{MB}$ of RAM, at least a $2 \mathrm{~GB}$ hard drive, CD-ROM, Ethernet card and a 17 inch monitor. The processor would be either a $90 \mathrm{MHz}$ or a $100 \mathrm{MHz}$ Pentium. The use of dual processors would be advantageous to increase the "crunching" power required by packages such as Integraph's Voxel. Possible contenders are Intergraph's TD4 (which is a dual processor system) and other $100 \mathrm{Mhz}$ Pentium systems available on the market from vendors such as Zeos.

b. The client workstation:

This machine would serve as the client, or as an independent workstation. The hardware requirements are very much the same as the server, except that a dual processor may not be necessary and the hard disk could have the capacity of 1 GB. A 20 inch monitor will be necessary since a lot of development work will be done on this machine. Possible contenders are Intergraph's TD3 and machines from other vendors

c. The laptop field computer:

The requirements for this machine are $32 \mathrm{MB}$ RAM, $1 \mathrm{~GB}$ Hard drive, $100 \mathrm{MHz}$ Pentium processor, Ethernet card and a CD ROM. The display could be an LCD with a resolution of $640 \times 480$. 
Task 3: Devise and Specify an Integrated System

Our work in the first quarter has concentrated on requirements determination. However, several aspects of this effort contribute to Task 3. The ARC/INFO training has provided a detailed technical understanding of the operation of a GIS system as a whole. It helped us in identifying the data and processing requirements of each component of a GIS. The training included creation of usable data from field data, cataloging field data, use of existing data, creation of maps, plotting of maps, understanding the link between various components and the transformation of data by each component.

The work in selecting hardware and software candidates for evaluation has also contributed to gaining a clearer focus on requirements for an integrated system.

\subsection{Schedule and Costs}

Due to a late task award, we are slightly behind our original plan in both schedule and spending rate. We do not consider this to be a significant problem, however, and expect to make significant strides during the second quarter in schedule and resource use.

Task status is as follows:

Task 1 is essentially complete ... material will be transmitted in the first two weeks of April. Task 2 is about $90 \%$ complete, and will be completed during April.

Task 3 was begun during the current quarter, and is about $10 \%$ complete.

Tasks 4 and 5 are scheduled to start late in the year.

Costs for the first quarter were (unofficially):

Personnel (including fringe benefits)

Travel and Training

Indirect Costs $(38 \%)$

Total:
$\$ 8,125.86$

$3,384.52$

$4,373.94$

$\$ 15,884.32$

\subsection{RESULTS AND DISCUSSION (CURRENT PERIOD)}

Section 5.1 contains a description of our efforts during this first calendar quarter, and intersperses some discussion and results. We provide here a brief summary of the results from this period.

Preparation of information required for the National Environmental Policy Act has been completed. The material will be transmitted during the first half of April.

Requirements determination is nearing completion. We have received input from Corps personnel, have consulted available literature and product specifications, have made direct contacts with vendors, have attended a workshop on ARC/INFO, and considered our prior evaluation of ICASE/GRACE.

We have determined that we should obtain the Intergraph MGE Windows NT GIS system for in-depth evaluation and experimentation. This decision is based on the following considerations: (a) MGE is a fullyfunctional generic GIS system, and there is a broad offering of related products that may be important for remediation use; (b) the Huntington Corps office has already obtained MGE in order to be compatible with the 
Nashville district office; (c) MGE is the only PC-based generic GIS system that is adequate for the Corps largevolume data requirements.

We have determined that Microsoft (MS) SQL Server will be obtained for evaluation and experimentation with MGE, for the following reasons: (a) MS SQL Server runs under Windows NT, which is the operating system we will use for MGE, and supports the client-server architecture; (b) although the Corps uses Oracle, it isn't currently available under Windows NT (they currently use it on a Unix system)--an NT version is forthcoming; (c) Oracle would be very expensive for us to obtain; (d) both MS SQL Server and Sybase SQL server are candidate alternatives, both available under NT; (e) MS SQL and Sybase are functionally similar; ( $f$ ) we can obtain MS SQL Server at low cost under a university discount; (g) by use of MS SQL Server we can ensure the "transparency" of the database in use by comparing Oracle queries with MS SQL Server queries.

We will obtain Windows NT as the operating system, since MGE is NT-based, and there is a very strong trend toward NT for PC workstation use. The networking features of NT will provide the support we require for the client-server architecture.

We will purchase computing hardware during the second quarter that adequately supports MGE under the Windows NT operating system, and provides the range of applicability necessary to conduct full experimentation within the Corps setting. Specifically, as detailed in section 5.1 above, we plan to purchase three "high end" PCs for the roles of client workstation, server workstation, and laptop field computer.

\subsection{CONCLUSIONS (CURRENT PERIOD)}

We made very good progress during this quarter, which puts us in an excellent position to successfully complete all tasks during this calendar year. We did not staff the effort to the projected level for the first quarter due to the late award, but we did proceed with a level of effort in anticipation of the award which will enable us to successfully conduct the work during the calendar year. Our approach now will be to increase labor hours, especially during the next two calendar quarters, and we also plan to purchase computing hardware and software during the second quarter.

We have prepared the National Environmental Policy Act Material, and are nearing completion of requirements determination. We are now in position to acquire necessary computing hardware and software to undertake intensive experimental evaluation of the Intergraph MGE system within the setting of Corps of Engineers remediation needs.

We have established a very productive working relationship with geotechnical/environmental personnel in the Corps Huntington district office, and anticipate a very fruitful collaborative effort as we undertake experimental evaluation of the software and hardware. 


\subsection{WORK PLANNED FOR NEXT PERIOD}

\subsection{Activities}

Following is a summary of major activities planned during the second quarter of 1995 .

\section{Presentation to DOE/METC}

An oral presentation will be provided to DOE/METC project managers in Morgantown during April. Material presented will be submitted in written form as well.

\section{Task 2: Determine System Requirements}

This task will be completed, and a detailed requirements description will be generated.

Task 3: Devise and Specify an Integrated System

Computing hardware will be purchased and installed during this quarter, as described in sections 5.0 through 7.0 above. The Intergraph MGE system and supporting software (operating system, network software, database system) will be acquired and installed.

Key personnel will attend a forty-hour Intergraph-taught training course on MGE.

Representative remediation site data will be obtained in cooperation with Corps personnel, and experimental evaluation of the MGE system will begin.

\subsection{Schedule and Costs}

Projected costs for the second quarter are:

$\begin{array}{lc}\text { Personnel (including fringe benefits) } & \$ 26,790.26 \\ \text { Travel and Training } & 11,790.00 \\ \text { Hardware/Software } & 30,000.00 \\ \text { Indirect Costs (38\% excluding hardware/software) } & 14,660.50 \\ & \\ \text { Total: } & \$ 83,240.76\end{array}$

Following is a chart which summarizes schedule and costs--both actual and projections--as of March 31 , 1995. The only schedule revision shown is a slight delay in Task 2 due to a late award. For convenience, a summary of task titles and durations are repeated here.

Task 1 Information Required for the National Environmental Policy Act: due within 60 days after award

Task 2 Determine System Requirements: January 1 through March 31, 1995

Task 3 Devise and Specify an Integrated System: January 1 through November 30, 1995

Task 4 Determine Operating Procedures: October 1 through November 30, 1995

Task 5 Develop Materials for Technology Transfer: November 1 through December 31, 1995 
Schedule and Costs: Status and Projections as of March 31, 1995

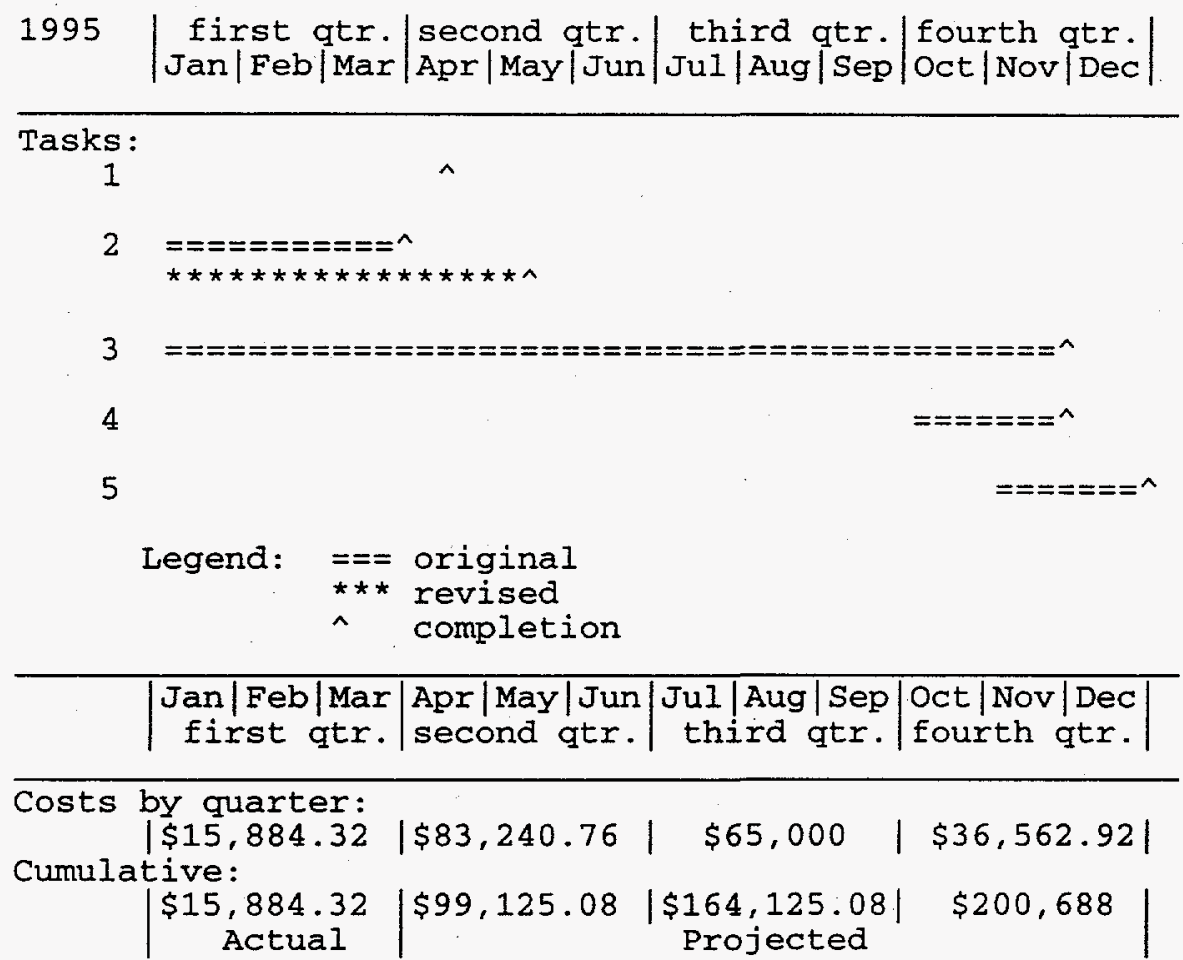

\subsection{TECHNICAL/ADMINISTRATIVE DIFFICULTIES}

None. 


\section{APPENDICES}

\section{A. REFERENCES}

1. MANAGEMENT, VISUALIZATION, AND ANALYSIS OF ENVIRONMENTAL AND GEOTECHNICAL DATA, Final Report, Subcontract 88-0716-MURC01, DOE Cooperative Agreement DE-FC21-MC29467, September 1994.

\section{B. LIST OF ACRONYMS AND ABBREVIATIONS}

$\begin{array}{ll}\text { CD-ROM } & \text { compact disk read only memory } \\ \text { DOS } & \text { Disk Operating System } \\ \text { ERMA } & \text { Environmental Resource Management Application (an Intergraph product) } \\ \text { GB } & \text { gigabyte; approximately 1,000 MB } \\ \text { GIS } & \text { geographic information system } \\ \text { ICASE/GRACE } & \text { Integrated Computer Assisted Site Evaluator/Graphical Remedial Assessment and Cost } \\ & \text { Evaluator } \\ \text { LCD } & \text { liquid crystal display } \\ \text { MB } & \text { megabyte; approximately one million bytes } \\ \text { MGE } & \text { Modular GIS Environment (an Intergraph product) } \\ \text { MHz } & \text { megahertz } \\ \text { MS } & \text { Microsoft } \\ \text { NT } & \text { New Technology (as part of Windows NT) } \\ \text { PC } & \text { personal computer } \\ \text { RAM } & \text { random access memory } \\ \text { SQL } & \text { System Query Language } \\ \text { USACE } & \text { United States Army Corps of Engineers }\end{array}$




\title{
SMALL BUSINESS SUPPORT PROGRAM METC TASK NO. 3.3
}

\author{
Quarterly Technical Progress Report \\ Reporting Period: \\ Jan. 1 - Mar. 31, 1995 \\ Work Performed Under Contract \\ No.: DE-FC21-92MC29467
For:
U.S. Department of Energy
office of Fossil Energy
Morgantown Energy Technology Center
Morgantown, West virginia

\author{
By: \\ E.E. (Bud) Cook \\ Department of Civil Engineering \\ West Virginia University
}


$-350-$ 
Task 3.3, Small Business support Program, was initiated to address the technical problems or barriers to commercialization of the innovative site remediation technologies developed by the small businesses that are funded by METC. Once a problem or opportunity was defined, researchers from WVU, Marshall or other sources would be solicited to work with the small business in a research project to solve the problem or alleviate the barrier.

Additionally, a new small business incubator program targeted towards site remediation and small businesses in the West virginia region was initiated.

2.0 Purpose

The Small Business Support Program was initiated to explicitly address the problems and barriers to commercialization of the innovative site remediation technologies developed by the small businesses funded by METC.

3.0 Background

Over the past two years the METC/WVU Cooperative Agreement has funded numerous projects at WVU and Marshall University. This has resulted in defining at least three areas of core competencies at WVU which may be called upon to provide assistance to the small businesses that METC funds in the area of site remediation.

The core competencies are found mainly in the in-situ remediation area including:

* Remediation Processes such as surfactant flushing of soils and chemical and biological destruction of polyaromatic chlorinated hydrocarbons

* Confinement Barriers such as the Circulating Air Barrier and Chemical Grouting Barriers

* Fluid Recirculating Systems such as the Drain Enhanced surfactant Flushing

4.0 Methodology

By attending the kickoff meetings and other periodic meetings of the small businesses funded by METC an understanding of the project is obtained. During the presentations, value added opportunities for collaboration between the small businesses and university researchers are carefully watched for. Discussions with program managers also provide opportunities for interaction. The newly formed Environmental Waste Management Technical Product Team will 
also provide an opportunity to determine needs of the small businesses and resulting research opportunities. For the long range research opportunities, the new initiative at DOE HQ level bringing together elements from DOE, DOD, NASA, Commerce and others to coordinate interagency site remediation capabilities and needs will be very helpful.

Also, attendance at various meetings and conferences on site remediation provides insights to research needs.

From all of the previous sources research opportunities are ferreted out and projects are developed with university faculty to carry them out.

5.0 Work Performed This Period

In Task 3.3 "Small Businesses Support Program" a number of new small business contacts and initiatives were begun.

During January 1995 visits were made to Manufacturing and Technology Conversion International Inc. (MTCI) and spintek, both located in the suburbs of Los Angeles, California. MTCI has been funded through the cooperative Agreement for a period of time. Several new tasks are being developed as opportunities arise. One of the new tasks being developed is to initiate a research program with spintek and if monies are available it will begin mid-year.

Another new task is demonstration of the drain enhanced soil flushing technology (DESF) in collaboration with Nilex Corporation, a manufacturer of the wick drain.

A third new task being developed is support of the small business incubator for site remediation technologies. This is in cooperation with the West Virginia High Tech consortium. This will be funded in the near future.

The newly formed and DOE HQ sponsored initiative to coordinated interagency use of site remediation technologies has asked WVU to provide graduate student interns to work with them. At least four graduate students from engineering/ science, computer systems, and journalism are being interviewed for the task.

6.0 Results and Discussion N/A

7.0 Conclusions N/A 


\section{APPROACH FOR ASSESSING POTENTIAL VOLUNTARY ENVIRONMENTAL PROTECTION, KANAWHA VALLEY AREA}

Quarterly Technical Progress Report

for Period January 1 through March 31, 1994

Work Performed Under

Contract No.: DE-FC21-92MC29467

For

U.S. Department of Energy

Office of Fossil Energy

Morgantown Energy Technology Center

P. O. Box 880, Collins Ferry Road

Morgantown, West Virginia

By

Raymond J. Lovett

National Research Center for Coal and Energy

Environmental Technology Division

West Virginia University

Morgantown, West Virginia 26506

James J. Kohanek

Clean Sites, Inc.

Alexandria, VA

Paul Hill

National Institute for Chemical Studies

Charleston, WV

April 1995 
$-354-$ 
This project concerns investigation of the feasibility of establishing voluntary remediation programs in the Kanawha Valley, WV. 
$-356-$ 
TABLE OF CONTENTS

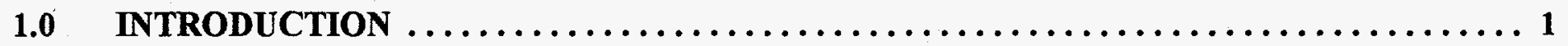

2.0 WORK PERFORMED THIS PERIOD $\ldots \ldots \ldots \ldots \ldots \ldots \ldots \ldots \ldots \ldots \ldots \ldots \ldots \ldots \ldots$

3.0 WORK PLANNED FOR NEXT PERIOD $\ldots \ldots \ldots \ldots \ldots \ldots \ldots \ldots \ldots \ldots \ldots \ldots \ldots \ldots \ldots$

4.0 TECHNICAL/ADMINISTRATIVE DIFFICULTIES $\ldots \ldots \ldots \ldots \ldots \ldots \ldots \ldots \ldots \ldots$ 
$-358-$ 


\subsection{INTRODUCTION}

The objective of the project will be to first assess the interest and willingness of industry in the Kanawha River Valley to participate in discussions that would lead toward voluntary cleanup activities. The second will be to implement the activities agreed upon by the interested parties. The project will first involve individual discussions with the industrial, government, and other organized groups in the area. These discussions will help determine the feasibility of organizing voluntary efforts. If the discussions indicate that conditions may be favorable for developing individual or group voluntary cleanup projects, a working group will be convened to establish the environmental goals of the project as well as the technical approach for achieving those goals.

\subsection{WORK PERFORMED THIS PERIOD}

A kick-off meeting was held at METC on March 16. No other work has been performed yet.

\subsection{WORK PLANNED FOR NEXT PERIOD}

Discussions will be scheduled and the assessment of interest initiated.

\subsection{TECHNICAL/ADMINISTRATIVE DIFFICULTIES}

Funding was not received until March 10, which delayed the start of the project until late in the quarter. 